\title{
The Rail and the Cross in West Virginia Timber Country: Rethinking Religion in the Appalachian Mountains
}

Joseph F. Super

Follow this and additional works at: https://researchrepository.wvu.edu/etd

\section{Recommended Citation}

Super, Joseph F., "The Rail and the Cross in West Virginia Timber Country: Rethinking Religion in the Appalachian Mountains" (2014). Graduate Theses, Dissertations, and Problem Reports. 6744.

https://researchrepository.wvu.edu/etd/6744

This Dissertation is protected by copyright and/or related rights. It has been brought to you by the The Research Repository @ WVU with permission from the rights-holder(s). You are free to use this Dissertation in any way that is permitted by the copyright and related rights legislation that applies to your use. For other uses you must obtain permission from the rights-holder(s) directly, unless additional rights are indicated by a Creative Commons license in the record and/ or on the work itself. This Dissertation has been accepted for inclusion in WVU Graduate Theses, Dissertations, and Problem Reports collection by an authorized administrator of The Research Repository @ WVU.

For more information, please contact researchrepository@mail.wvu.edu. 
The Rail and the Cross in West Virginia Timber Country: Rethinking Religion in the Appalachian Mountains

\author{
Joseph F. Super
}

\begin{abstract}
Dissertation submitted to the Eberly College of Arts and Sciences at West Virginia University in partial fulfillment of the requirements for the degree of
\end{abstract}

\author{
Doctor of Philosophy \\ in \\ History
}
Kenneth Fones-Wolf, Ph.D., Chair Elizabeth Fones-Wolf, Ph.D. Brian Luskey, Ph.D.
Krystal Frazier, Ph.D. Jane Donovan, D. Min.

Department of History

Morgantown, West Virginia 2014

Keywords: railroads, religion, West Virginia

Copyright 2014 Joseph F. Super 


\begin{abstract}
The Rail and the Cross in West Virginia Timber Country: Rethinking Religion in the Appalachian Mountains
\end{abstract}

\title{
Joseph F. Super
}

West Virginia underwent significant changes in the four decades between 1880 and 1920. The Gilded Age and the Progressive Era witnessed political, social, cultural, and economic upheavals as industrialists looked to exploit natural resources and propel the Mountain State into a position of leadership in a modern national economy. Railroads opened up the remote interior counties, paving the way for the oil, coal, and timber industries. The West Virginia Central and Pittsburg Railway, under the direction of Henry Gassaway Davis, scaled the highest peaks of the Allegheny Mountains. Davis and his business associates quickly took control of the timber and coal reserves in the mountain counties. Local elites allied themselves with larger capitalists, forming partnerships which enabled outsiders to dominate local political and economic life throughout the period.

Religious transformations characterized the period as well. Nation-wide, Protestant missionaries moved into the South, seeking to evangelize, educate, and uplift whites and blacks. Northern churches paid particular attention to the mountain South. However, West Virginia received significantly less money and manpower from national denominations than the other states in Appalachia. State and local religious organizations stepped in and ensured that the rapidly increasing population of the state would not go un-reached. They used the railroad to their advantage as well.

Methodists, Baptists, and Presbyterians, the three largest Protestant groups in the country and in West Virginia, led the way. All three already had some presence in the mountains, and denominational networks ensured that these mountain churches had some ties to mainline Christianity. Missionaries working in the most remote regions reinforced traditional doctrine and practice while strengthening denominational ties. Churches attracted people of all social ranks, although Methodists and Baptists offered more opportunities for working class members. While the secular affairs of mountain communities and counties remained firmly in control of industrialists and their local affiliates, the sacred sphere remained open for all.

At the same time, churches across the state joined in increasingly loud calls for moral reform, particularly for new Sabbath and temperance laws. Thus, Protestant churches across the state reflected a mainline yet conservative doctrinal outlook that emphasized denominational distinctives while championing a unified, broadly Protestant culture for the creation of sought-after Christian America. Industrialists such as Henry Gassaway Davis shared the vision of a Christian America and favored many of the same moral reforms. They worked together with churches to achieve common goals. However, despite the autonomy of the sacred sphere, the secular sphere had become dominant in the Alleghenies, in West Virginia, and in the United States. Thus, when the goals conflicted, as in the case of Sabbath reform, the secular usually won, thus further weakening and isolating the sacred. 


\section{Acknowledgements}

This project has been a labor of love. Perhaps like many in my situation, I started out with great enthusiasm, got bogged down somewhere in the middle, and finally straggled across the finish line, collapsing in a heap. I never travelled great distances from Morgantown and I never had to board a plane, but I drove all over five counties in the West Virginia highlands, up mountains, down hollows, over gravel roads, and off maps. I hounded pastors, elders, deacons, secretaries, librarians, archivists and lay people to get access to records which, unfortunately, had too often been all but forgotten. I felt a great sense of accomplishment upon actually completing the dissertation. Looking back, however, the most rewarding part of this entire experience was seeing the smiles on the faces of the people I encountered along the way. They genuinely appreciated the fact that a stranger to their towns, homes, and churches cared enough to take the time just to listen to their stories and dig through their record books. These people are too numerous to mention here, but this work could never have materialized without them. I am truly grateful for their help and the work they continue to do, at times un-thanked and unnoticed, for their congregations and denominations.

This dissertation would also not be possible without the efforts of my committee. Ken, Liz, Brian, Jane, and Krystal have all taken time out of their lives - personal and professional to make this project a reality. Ken first suggested doing a dissertation on Appalachian religion sometime during my first year at WVU. The finished work is far from what he first brought up, but he started me down the right path. I have taken several classes with Liz, Brian, and Jane and my approach to history and religious studies has been critically shaped by these experiences. They challenged me to go in directions I never knew existed. Furthermore, Jane has been crucial in my understanding of Methodism and acted as a sounding board throughout the writing process. Krystal graciously stepped at the eleventh hour and agreed to bring her knowledge and expertise to the work.

I am eternally indebted to my parents - Joe and Deb Super -- for the love and support they have given me my entire life. They encouraged me literally every step of the way along my educational journey, from the time I started school as a Little Mountaineer at Third Ward Elementary School to when I finally finished as a big Mountaineer at West Virginia University. They cheered with me during the good times and cried with me during the bad. They picked me up when I fell and made sure I persevered. They never gave up on me and refused to let me give up on myself. Thank you for everything you have done, and everything you will do.

I owe a special thanks to my wife, Katie. She is my true love and sweetheart. She tolerated my travel schedule while we were dating and has endured me in very close quarters during the final stages of writing. While the subject matter is near and dear to my heart, her love is truly inspirational. I wanted to write a quality dissertation, and I hope I have. She, however, is my passion. Being the husband she wants and deserves far surpasses anything I have written or may yet write. She is a gift from God, and I will never take her for granted.

Last but not least, I suppose I also must thank Henry Gassaway Davis and Stephen B. Elkins, the co-founders of my hometown of Elkins, West Virginia. In a way, I owe my existence to these men, whom I discuss in greater detail below. The town of Elkins was their creation, and without it my parents would most likely not have met and I would never have been born. The railroad, the church, and the mountains are a part of me. These are their stories. 


\section{Table of Contents}

$\begin{array}{ll}\text { Acknowledgements } & \text { iii }\end{array}$

1: Introduction 1

2: The Sacred and the Secular in Reconstruction Era West Virginia: An Overview 29

3: Industry in the Mountains $\quad 69$

$\begin{array}{ll}\text { 4: Methodists } & 108\end{array}$

$\begin{array}{ll}\text { 5: Presbyterians } & 170\end{array}$

$\begin{array}{ll}\text { 6: Baptists } & 225\end{array}$

7: An Appalachian Social Gospel, or Becoming Fundamentalist? 274

8: Moral Reform 332

9: Comparisons and Conclusions 378

$\begin{array}{ll}\text { Bibliography } & 387\end{array}$

Appendix: Maps and Charts $\quad 409$ 


\section{1: Introduction}

“And Jesus said unto them, Because of your unbelief: for verily I say unto you, If ye have faith as a grain of mustard seed, ye shall say to this mountain, Remove hence to yonder place; and it shall remove; and nothing shall be impossible unto you." As recorded in the Gospel of Matthew, 17:20 (Authorized Version), Jesus spoke these words to the disciples after they failed to drive out a particularly powerful demon. While to date there is no documentation of a person, or group of people, moving an actual mountain merely by word of command, the verse does illustrate the function of faith in overcoming seemingly insurmountable obstacles.

This is a story about faith and mountains. More specifically, it is a story of two faiths Christian faith and development faith -- and many mountains - the several peaks of the Allegheny Mountains in West Virginia. The former faith is primarily concerned with the sacred realm - with the spirit or immaterial part of humanity and with the connection between people and God, as mediated in the Christian religion by the Scriptures, the church, and a relationship with Christ. The latter faith, by contrast, mostly belongs to the secular sphere. That sphere includes areas and aspects of life not specifically concerned with, involved in, or related to religion. Development faith, a term used by Appalachian and West Virginia historian John Alexander Williams and applied to the period of industrialization in West Virginia between roughly 1880 and 1920, describes a belief that the region's natural resources would support greater, more complex economic growth by providing raw material for industry, which would in turn lead to an increase in population and the creation of a service sector. West Virginia would thereby become a leading economic power in an industrialized America. ${ }^{1}$

While these two faiths principally occupy different provenances, they often overlap and

\footnotetext{
${ }^{1}$ John Alexander Williams, West Virginia and the Captains of Industry (Morgantown, WV: West Virginia University Press, 2003), 172, 173.
} 
interact, sometimes significantly. Such was the case in the West Virginia highlands between 1880 and 1920. The state experienced unprecedented industrialization and economic growth, as railroads penetrated the deep forests and scaled the high mountains and coal mines and saw mills dotted the landscape. At the same time, these secular developments facilitated sacred ones. Churches and missionaries used the railroad to establish new congregations and evangelize new territory.

What was the relationship between harvesting natural resources and harvesting souls? What was the link between building railroads and building churches? What was the nature of the sacred and secular conflict and encounter in West Virginia at this time? This study seeks to answer these questions by examining the process of industrialization and church growth in five West Virginia mountain counties - Mineral, Grant, Tucker, Randolph, and Pocahontas - between 1880 and 1920. These counties were all connected by the railroads of Henry Gassaway Davis and his associates.

While Davis himself was primarily concerned with coal, his railroad network opened the area for dozens of lumber companies looking to exploit the vast tracts of virgin forest, some of which established small logging railroads of their own. For the most part, Davis and his associates were the first to open these counties to large-scale industrial development, which the timber companies initially spearheaded. These counties, or at least significant parts of them, had not seen the railroad before. This process, begun around 1880, radically reconfigured life in the West Virginia highlands. Immigrants poured in by the thousands, new towns were established all along the track, and the counties witnessed strong capitalist influence on the location of county seats, with outright violence threatened in some situations.

The railroads brought religion as well. Methodists, Baptists, and Presbyterians, the three 
largest Protestant groups in the nation, all specifically used trains as a means of evangelization. With new towns came new churches, and existing churches grew larger. By studying the history of these churches in conjunction with the history of counties, towns, and companies during the period, this dissertation has two principal aims. First, it explores the nature of Appalachian religion in the late nineteenth and early twentieth centuries. The religious history of these five counties reveals the complex relationships among local, state, and national religious bodies. Simply assuming that those churches in the mountains which refused to associate beyond the immediate local level are representative of the whole is seriously misleading. Strong similarities existed in religious culture and beliefs, even in the presence of stark differences. Many of the existing churches in the region had long-established ties with the major national denominations. The railroad strengthened these by allowing greater communication and contact between Appalachia and the rest of the country. Furthermore, missionaries from the state and national levels had greater access to the region, establishing new churches and reinforcing denominational positions in the state.

Second, this study uses religion as a framework in which to analyze the overarching cultural themes of the period. Religion in West Virginia reveals the interconnectedness of the sacred and secular spheres. The advent of industrial capitalism not only changed political, social, and economic relations, but also wedded the sacred and secular in the mountains in ways similar to the rest of the country. The events in the mountain counties covered here demonstrate how and why this process occurred. They reveal the dominance of the concept of Christian civilization during the Gilded Age and Progressive Era. Over forty years, the secular elements of that vision achieved superiority over the sacred components. Whereas religion itself had once taken priority, with civilization following closely behind, now things were changing. As 
historian Robert Handy notes, proponents of Christian civilization "were in effect making the advancement of civilization the greater good, thus subtly reversing the earlier priority."2

Heavy industry was not just a way to make more money or better the lives of individuals, it was a means to a specific end: a stronger, better, more unified country -- and therefore an indicator of civilization itself. It was this mind-set which further conditioned the development of mountain society during the period. Religion, because it was another marker of civilization, constituted another force working in the mountains. Because of the religious similarities between the Alleghenies and the rest of the country, religion facilitated the region's move into the dominant culture. This was accomplished as much, if not more, by the religious culture already prevalent in the mountains as it was by the religious attitudes missionaries and others brought with them. At the same time, this traditionalist faith blocked secular forces from completely over-taking it or co-opting it. Churches in the mountains remained capable of determining their role in society and in local communities and of deciding how best to fulfill those responsibilities.

The locomotive was an awesome power that sparked incredible transformation wherever it went. Trains represented the agency and activity of progress, of civilization. Far from being a passive object, however, religion here is an active subject as well. Its adherents followed a path determined not by a faith that ran over, under, and through mountains, but by a faith not limited by merely physical boulders, heights, and precipices. The story here illustrates what happened when these two tracks, these two faiths, crossed.

\section{Literature Review}

The research presented here directly interacts with existing literature on Appalachian religion in particular and American religion in general. To date, Appalachian Mountain Religion,

\footnotetext{
${ }^{2}$ Robert T. Handy, A Christian America: Protestant Hopes and Historical Realities (New York: Oxford University
} Press, 1984). 
by Deborah Vansau McCauley, is the broadest study of Christianity in Appalachia. Her coverage contains both general and specific examinations of religion in the mountains. She offers a general chronological overview of Christianity from colonial times to the present. In completing her account, she goes into great detail on the involvement of national denominations in the regions, including Baptists, Methodists, and Presbyterians. She examines the beliefs and practices of sub-denominations and regional groups, such as Old Regular Baptists and nondenominational holiness churches, and compares and contrasts those of the larger bodies. Finally, the book charts the history of missionary work in the region.

Appalachia was "discovered" by Northern missionaries in the 1880s. Mission work consisted not just of religious conversion, but also of cultural conversion. She highlights the religious and cultural differences between these mainline missionaries and the Appalachians they endeavored to convert. Appalachian religion was essentially different from that of the rest of America, shaped by the unique cultural, social, and geographic circumstances of the region. Missionaries from national denominations struggled to recognize and accept the legitimacy of the religion they encountered in the mountains. ${ }^{3}$

McCauley constructs what has become the leading analytical framework for the study of Appalachian religions, what she calls "the mountain church tradition." "Mountain church traditions are not grounded in the institutional structures and confines of denominationalism that characterize Roman Catholicism and the churches of America's Protestant mainstream...” she

\footnotetext{
${ }^{3}$ Deborah V. McCauley, Appalachian Mountain Religion (Chicago: The University of Illinois Press, 1995). See also John D. Photiades, ed. Religion in Appalchia: theological, social, and psychological dimensions and correlates (Morgantown, WV: West Virginia University Center for Extension and Continuing Education, 1978). This collection of essays focuses almost exclusively on the holiness and Pentecostal sects that formed, and still form, a religious minority in the state.
} 
asserts. ${ }^{4}$ This "tradition" consisted of both practices/doctrines and the organized church bodies which exemplified and adhered to these beliefs. The churches were either independent or very loosely associated with each other into sub-denominations, so called because they did not have national organizational structures. Independent nondenominational holiness churches and small Baptist groups such as the Primitives, United, and Old Regular constituted the broad center of a peculiar mountain sacred identity.

The distinct ethos of these groups was not simply the remainder of a bygone era in the history of American Protestantism. Not to be equated or confused with Southern religion or fundamentalism, mountain religiosity possessed its own history. At the same time, this religiosity did not originate with one particular church or Christian sub-group. Each mountain church drew from a reservoir of ideas, beliefs, and practices and exhibited them in its own way. Such a wellspring included such customs and traditions as strong emotional piety, the centrality of non-propositional religious experience mediated by the Holy Spirit, plain folk camp meeting revivals, and simple faith in Jesus. ${ }^{5}$ At its very core, then, mountain religion is not defined by doctrinal theology or creedal assent. Rather, it is defined by the need for "the human heart to

${ }^{4}$ Deborah Vansau McCauley, "Religion," in High Mountains Rising: Appalachia in Time and Place, Richard A. Straw and H. Tyler Blethen, eds. (Chicago: University of Illinois Press, 2004), 180. Churches numbered in the ranks of America's Protestant mainstream include, but are not necessarily limited to, the Presbyterian, Lutheran, Episcopalian, United Methodist, Reformed Church in America, American Baptist Churches, the Southern Baptist Convention, United Churches of Christ and the Christian Church. Also excluded from the foundation of mountain religious traditions are such national holiness and Pentecostal denominations as the Church of the Nazarene and the Assemblies of God, although these are not counted as mainstream Protestant bodies either. In the introduction to Christianity in Appalachia, Bill Leonard offers a more precise break-down of the various denominations. He agrees with McCauley's list of mainline denominations, with some exceptions. The Southern Baptist Convention is considered an evangelical denomination, along with "Nazarenes, the Churches of Christ, Bible churches, and other independent, non-denominational, non-Pentecostal groups." The Church of God, Assemblies of God, and similar churches are grouped under the Pentecostal heading. The mountain churches, such independent holiness and Pentecostal congregations and various Baptist communions, could also be grouped with either the Pentecostal or evangelical sects, but they are unique to Appalachia and "constitute a distinctive expression of religion in Appalachia," and so merit their own category. See Leonard, Christianity in Appalachia, xxi.

${ }^{5}$ McCauley, Appalachian Mountain Religion, 7, 25, 26, 265, 266. 
inform and direct the human intellect, rather than the other way around."

While not devoted exclusively to religion, Appalachia On Our Minds by Henry Shapiro contains an excellent chapter on denominational mission work in the region. It predates McCauley's work, but it takes a similar approach, concentrating on the differences between Christians in the mountains and those missionaries who came into the highlands to convert and civilize those whom they thought lacked true religion. Shapiro employs solid primary source material on Presbyterian, Methodist, and Congregationalist home missions, almost all of it coming from national levels of the respective churches. As extensive as the research is at these highest echelons, the chapter contains very little from state groups and local churches. Thus, the portrayal of Appalachian religion lacks balance, focusing only on the perspective of outsiders. ${ }^{7}$

Books by Richard Callahan and Crandall Shifflett examine religion in the coalfields of southern Appalachia. Shifflett devotes a chapter to company churches and their place in the lives of the miners in Southern Appalachia. In Work and Faith in the Kentucky Coalfields, Callahan studies the rise of independent Pentecostal-Holiness churches in the coalfields of eastern Kentucky after 1910. These new churches sprang directly from local opposition to mainline denominations associated with industrialists, as dissenting churchgoers sought to maintain some form of independence from their new bosses. Beyond just autonomy, these new churches expressed "new-yet-traditional" worship practices that reflected the struggles and tensions of everyday industrial life better than the modernist "railway" faith or the comparatively dry and doctrinaire Old Regular Baptists indigenous to the area. ${ }^{8}$

\footnotetext{
${ }^{6}$ McCauley, "Religion," 184.

${ }^{7}$ Henry D. Shapiro, Appalachia on Our Mind: The Southern Mountains and Mountaineers in the American Consciousness, 1870-1920 (Chapel Hill: The University of North Carolina Press, 1978).

${ }^{8}$ Crandall A. Shifflett, Coal Towns (Knoxville: The University of Tennessee Press, 1991); Richard J. Callahan, Jr., Work and Faith in the Kentucky Coal Fields: Subject to Dust (Bloomington: Indiana University Press 1982).
} 
Callahan's work borrows heavily from McCauley's research and builds upon the "mountain religious tradition" paradigm. Interestingly, however, Callahan uses a method predicated upon the pre-existing religious differences between pre-industrial Appalachia and the rest of America to show how industrialization caused religious difference. This is not inherently contradictory, but it should raise critical questions about the very nature of Appalachian religion and the methodological approach taken to investigate it. McCauley asserts that Pentecostalism helped form the core of an Appalachian religious culture different from and untouched by modern America. Callahan's treatment of Pentecostalism in Kentucky shows it as, at least in part, a reaction against industrialization and modernization. ${ }^{9}$ While these conclusions are not necessarily contradictory, or incorrect, they should prompt a closer inspection of the nature and development of Appalachian religion.

Howard Dorgan, Loyal Jones, and Clifford Grammich each conduct examinations of the contemporary counterparts of some of McCauley's and Callahan's subjects. Dorgan and Grammich each deal with specific bodies of Baptists in North Carolina, Tennessee, eastern Kentucky, and southwestern Virginia. Each church group existed almost exclusively in Appalachia. Most of Dorgan's work is admittedly descriptive, seeking to record the beliefs and practices of these comparatively small sub-denominations and detailing how they continue to differ from national groups. ${ }^{10}$

The Tennessee Baptists in Grammich's Local Baptists, Local Politics adhered to a traditionalist interpretation of the Bible and developed a political view from that. As the author

\footnotetext{
${ }^{9}$ McCauley, Appalachian Mountain Religion, 255; Callahan, 60, 61.

${ }^{10}$ Howard Dorgan, Giving Glory to God in Appalachia: Worship Practices of Six Baptist Subdenominations (Knoxville: University of Tennessee Press, 1987).
} 
explains, this framework, while appearing similar to Fundamentalism, was distinctive and grew from the cultural, social, and political circumstances in the Tennessee mountains. Like McCauley, Loyal Jones posits the essential difference between mainstream American Christianity and Appalachian Christianity. His work is based on both written and oral records about church practices. Unlike Dorgan or Grammich, Jones does not systematically look at the various denominations. Instead, he examines beliefs in sin, salvation, God, Satan, and preaching, comparing and contrasting the views of several Appalachian denominations on each point of doctrine. ${ }^{11}$

This study also intersects somewhat with the broader literature on Appalachia and will rely heavily upon various studies of industrialization in Appalachia and West Virginia. Scholars such as Ronald Lewis, John Alexander Williams, and Ronald Eller have thoroughly explored the social, political, and economic changes brought to Appalachia in general and West Virginia in particular. In Transforming the Appalachian Countryside, Ronald Lewis carefully chronicles the advent of the railroad and the growth of the timber industry in the mid-Allegany region of West Virginia from 1880-1920. His work covers much the same region as does this study and deals with many of the same themes. The book explores the many ways in which industry transformed not just the state, but also counties and communities. This broad treatment covers law, politics, culture, social life, and the environment. ${ }^{12}$

The industrial age in West Virginia was a time of contact and encounter, just as it was in

\footnotetext{
${ }^{11}$ Clifford A Grammich, Jr. Local Baptists, Local Politics: Churches and Communities in the Middle and Uplands South (Knoxville: University of Tennessee Press, 1999); Loyal Jones, Faith and Meaning in the Southern Uplands (Urbana: University of Illinois Press, 1999). See also David Whisnant, All That is Native and Fine (Chapel Hill, NC: The University of North Carolina Press, 1983) and Bill Leonard, ed. Christianity in Appalachia (Knoxville: The University of Tennessee Press, 1999).

${ }^{12}$ Ronald L. Lewis, Transforming the Appalachian Countryside: Railroads, Deforestation, and Social Change in West Virginia, 1880-1920 (Chapel Hill: University of North Carolina Press, 1998).
} 
any other place. Lewis is quick to point out the similarities between pre-industrial society and the industrial capitalist way of life which rode in on the Iron Horse. The historiography of mountain culture and life before 1880 is carefully considered. The original Jeffersonian myth of an egalitarian, agrarian, yeoman society in the back country is still prevalent and powerful, but the most recent scholarship indicates more economic diversity, social stratification, and ownership inequality. Although the plantation system of the east never took root in the highlands, hierarchical values took root nonetheless. Absentee owners controlled considerable acreage, especially in West Virginia. ${ }^{13}$

Lewis offers a very thorough treatment of the secular realm in the Alleghenies. For this reason, the book heavily informs this study. However, Lewis says very little about religion and the sacred sphere. This work will compliment secular studies by examining and highlighting the sacred sphere in those counties and others. This present work is more than simply a chapter on Appalachian religion to be appended to other books. Discursive dialogue between the secular and sacred are fleshed out more here than in other treatments of the period and its events. This allows for more complete and nuanced understandings of the exchange and encounter that took place and of the complex relationships between secular and sacred, local and national.

Two other studies of Appalachian economic and political development merit mention. West Virginia and the Captains of Industry, by John Alexander Williams, offers a critical look at the process of industrialization in West Virginia, and thus will be quite valuable here. It is at once broader and narrower than Lewis's study. Industrial capitalists and politicians Henry Gassaway Davis and Stephen B. Elkins are the primary objects of his study. Between 1870 and

\footnotetext{
${ }^{13}$ Lewis, 248. See also Barbara Rasmussen, Absentee Landowning and Exploitation in West Virginia, 1760-1920 (Lexington: The University of Kentucky Press, 1994) for an extensive treatment of the history of absentee ownership in the state, especially Randolph and Tucker counties.
} 
1920, these two men, neither of whom were natives of West Virginia, dominated state politics and economic development. Similarly, Ronald E. Eller focuses primarily on the secular cultural and societal shifts resulting from industrialization, although he briefly discusses the role of religion in the preindustrial era. The transition from a farm-based economy to one based on industry altered work habits, social practices, and familial relations. ${ }^{14}$

Finally, this study draws heavily upon the literature on American culture and society in the Gilded Age and Progressive Era. Rather than making a purely original argument about the role of religion in American life at this time, this work seeks to expand upon existing understandings and place Appalachian religion and industrialization firmly in a national context. Surveys on the period as a whole, such as The Shaping of Modern America, 1877-1920 and New Spirits, 1865-1905, ably demonstrate the place religion occupied in the public conscience and the role it played. ${ }^{15}$ Moreover, scholars such as Robert T. Handy, Charles Howard Hopkins, Robert M. Crunden, Ken Fones-Wolf and many others have already gone into great detail to highlight the areas of intersection between the sacred and secular. In his classic work on the social gospel, The Rise of the Social Gospel in American Protestantism, Charles Hopkins shows how the movement grew organically out of the American social and cultural setting of the Gilded Age and Progressive Era. The book charts the relationship between changing religious views and changing material circumstances. The reform ethos had a long history in American Christianity, but the experiences of industrialization and urbanization worked to simultaneously sharpen the focus and broaden the scope of this passion, creating a Christianity concerned with the "whole

\footnotetext{
${ }^{14}$ John Alexander Williams, Appalachia: A History (Chapel Hill: The University of North Carolina Press, 2002); Williams, West Virginia: A History (Morgantown, WV: West Virginia University Press, 2001); Williams, West Virginia and the Captains of Industry (Morgantown, WV: West Virginia University Press, 2003); Ronald Eller, Miners, Millhands, and Mountaineers: Industrialization of the Appalachian South, 1880-1930 (Knoxville: The University of Tennessee Press, 1982).

${ }^{15}$ Vincent P. De Santis, The Shaping of Modern America, 1877-1920 (Wheeling, IL: Harlan Davidson, Inc, 2000); Rebecca Edwards, New Spirits, 1856-1905 (New York: Oxford University Press, 2006).
} 
social system."

Ken Fones-Wolf fleshes out how this process occurred at a local level. His study of Philadelphia looks at the confluence of religion and the labor movement in that city between 1865 and 1915. In key ways, Christianity circumscribed labor's quest for legitimacy. However, Christianity in turn was receptive to and influenced by the greater social concerns working class movements represented. ${ }^{17}$ In Ministers of Reform, Robert Crunden explores how artists, political leaders, social activists, and others formed the loosely-knit but powerful movement known as Progressivism. While working in different areas of life, these people shared a common goal of reform based on moral purification. Through the last decade of the nineteenth century and into the first twenty years of the twentieth century, Christianity provided a common language to use in perfecting American democracy. ${ }^{18}$

Robert Handy's A Christian America provides the most extensive coverage of this perception that America was a city on a hill. Handy traces the vision from the Puritans to the late twentieth century. There was a fluid relationship between American Christianity and the societal and cultural realities of the country. At times Christians were pro-active; at other times, they were reactive. In all cases they maintained that America was a Christian nation. Denominational records, sermons, and teachings of officials from across the Protestant spectrum show, for much of American history, a broad religious consensus, despite the presence of increasingly diverse

\footnotetext{
${ }^{16}$ Charles Howard Hopkins, The Rise of the Social Gospel in American Protestantism, 1865-1915 (New Haven: Yale University Press, 1940), 13.

${ }^{17}$ Ken Fones-Wolf, Trade Union Gospel: Christianity and Labor in Industrial Philadelphia, 1865-1915 (Philadelphia: Temple University Press, 1989).

${ }^{18}$ Robert M. Crunden, Ministers of Reform: The Progressives'Achievement in American Civilization, 1889-1920 (New York: Basic Books, 1982).
} 
opinions. $^{19}$

Handy's chapters on the Gilded Age and Progressive Era are particularly instructive here. He introduces the concept of "Christian civilization." Although it fueled lingering sectional animosity, in important ways the Civil War created circumstances in which the country could be truly united, not just politically but culturally as well. Christianity already constituted a common bond between North and South, East and West. That religion which helped divide the country could now be used to unite it in order to control the effects of immigration, urbanization, industrialization, and the intellectual revolution characterized by Darwin's theory of evolution. Spiritual and temporal progress would go hand-in-hand. Religion had always played an important role in society, and evangelicals still believed "in the full transformation of American life into a Christian society" and that now was the time to complete the transformation. ${ }^{20}$

This study explores how that quest for a Christian Civilization played out in a discrete situation. In doing so, it contrasts markedly with McCauley, Callahan, and others in two primary ways. First, it positions mainline Christian denominations, rather than sub-regional groups, at the center of Appalachian Protestantism. Similarity with the rest of America, not difference, is emphasized. Second, because the dominant literature focuses on difference and sub-regional churches, it maintains there was always cooperation between mainline Protestantism and modernizing forces such as industrialization, and that cooperation was detrimental to indigenous culture, religion included. This project takes a more nuanced and complex approach. Mainline churches certainly cooperated with industrialists; these groups worked together precisely because of the similarities between West Virginia and the rest of the country. However, major Protestant

\footnotetext{
${ }^{19}$ Handy, A Christian America: Protestant Hopes and Historical Realities.

${ }^{20}$ Handy, 57.
} 
churches frequently offered alternative views of society that conflicted with the goals of industrialists. This study demonstrates that tension between these two groups and highlights the complicated relationship between mainline Protestants and industrialists in West Virginia during the Gilded Age and the Progressive Era.

Records from state mainline denominational organizations in West Virginia clearly link Christianity, certain aspects of it in particular, to concept of civilization. Local church records are both more scarce and more mundane. However, contra the prevailing literature, the dominant church culture in the mountains was mainline, so the prevalence of these churches points to at the very least a wide-spread awareness of Protestantism's role in a rapidly evolving country.

The focus here on mainline religion allows an alternate entry point into Appalachian Christianity and, because of the religious similarities, enables a different approach to the relationship between secular and sacred in America at the time. Christianity was a powerful cultural and social force; its precise relationship to secular forces was constantly fluctuating. At the same time, this project demonstrates the continued autonomy of the sacred sphere, even if that space was shrinking.

Focusing on mainline denominations also calls into question the usefulness of the "mountain church tradition" paradigm. This concept is predicated upon difference, whereas this study concerns similarity. Thus, another paradigm is needed. The concept of popular religion is able to deal with the religious circumstances of the area and provide an analytical framework in which to understand the connections between Appalachian religion and mainstream American religion, as well to investigate the interplay between the sacred and the secular. This latter feature is particularly helpful for studying the period of industrialization due to the significant social, cultural, and even political upheavals stemming from that process. 
What is popular religion? The very phrase itself is difficult to define. Much of this difficulty comes from attempts to define the term "religion." While that is certainly a valid, and complicated, issue, for the purposes of this dissertation "religion" is really just synonymous with Christianity, and specifically Protestantism, as that is the only religion in question here. Even so, scholars struggle to define "popular religion" succinctly.

Peter Williams gives three characteristics that all popular religious movements exhibit, regardless of the specific religion with which they are associated. First, popular religious movements are extra-ecclesiastical. They are to some extent separate from, in tension with, and/or on the fringes of an official religious establishment. Second, in turn, popular religious beliefs do not flow through official ecclesiastical channels. Third, and also closely related to the first two, popular religion "looks for the signs of divine intervention or manifestation in the realm of everyday experience. ${ }^{21}$

Charles Lippy, due to confusion about defining the word "religion," prefers the term "popular religiosity." This, he writes, refers to a "dynamic process of creating and maintaining personal worlds of meaning and the interconnectedness of the religiosity of a people within a given society. 22 There are two major characteristics of popular religiosity. First, it asserts that "the world of everyday life is a realm of power, an arena where supernatural forces of good and evil are operative." ${ }^{23}$ Believers seek to gain access to that supernatural good, thereby participating in the triumph over evil. Second, adherents of popular religion realize and appreciate both the present and future aspects of life - the here and the hereafter, the now and the

\footnotetext{
${ }^{21}$ Peter W. Williams, Popular Religion in America: Symbolic Change and Modernization Process in Historical Prospective (Englewood Cliffs, NJ: Prentice-Hall, Inc., 1980), 17-19.

${ }^{22}$ Charles H. Lippy, Being Religious, American Style: A History of Popular Religiosity in the United States (Westport, CT: Praeger, 1994), 10.

${ }^{23}$ Charles H. Lippy, "Popular Religiosity in Central Appalachia," in Christianity in Appalachia: Profiles in Regional Pluralism, Bill Leonard, ed. (Knoxville: The University of Tennessee Press, 1999), 41-42.
} 
not yet. Whatever the present may hold, the future, because of the triumph of good, will be far superior to present reality and will transcend its physical bounds. ${ }^{24}$

Of course, almost all forms of religion, whether popular or formal, deal with connecting the individual and the collective to the divine. In this case, the distinguishing feature of popular religion is its comparative lack of order and organization. Formal, established religions seek to give their beliefs and practices coherency and consistency by systematizing them, using such various means as official seminaries or other training schools, commentaries on sacred texts, or systematic theologies, among others. On the other hand, popular religiosity lacks this scholastic need. $^{25}$

Lippy has already applied, to some extent, his criteria to Appalachian religion. It should be fairly easy to see how some of the Appalachian strains of Christianity fit into this paradigm. Faith healing and speaking in tongues are perhaps the most obvious examples of the human connection with God. Each gift signifies the direct and immediate work of the Holy Spirit in the believer. Similarly, the quest for holiness does not stem from legalism. Rather, the quest to follow the teachings of Jesus represents, among many things, the struggle on this earth between good and evil and the conviction that one's conduct in this life reflects his or her future, and in some sense, present, state. That is, because one is a follower of Jesus and will someday dwell with God, one should be holy, just as God is. ${ }^{26}$

These tenets can be applied to the mainline churches in Appalachia, and the concept of popular religion is extensively employed here. Within this framework, several similarities

\footnotetext{
${ }^{24}$ Lippy, "Popular Religiosity in Central Appalachia," 47.

${ }^{25}$ Lippy, Being Religious, American Style, 10, 11.

${ }^{26}$ Lippy, "Popular Religiosity in Central Appalachia," 42-47.
} 
between the major denominations, both inside and outside Appalachia, and the subdenominations and nondenominational churches become apparent. As Lippy states, referring to official denominational frameworks, one must not fail to "appreciate the depth of support these many structures provide for a way of looking at ordinary reality through a supernatural perspective."27 In other words, popular religiosity and formal ecclesiastical structures are not, by definition, necessarily antithetical to each other or mutually exclusive.

The concept of popular religion is useful here for three principle and interconnected reasons. First, because this study looks at national, state, and local denominational activities, using the framework of popular religion facilitates careful examination of the relationships between these levels, both inter- and intra-denominationally. Second, it facilitates a thorough investigation of how these denominations differed from each other in the mountains and how they differed from their co-religionists elsewhere in America.

Third, and perhaps most important, popular religion allows for a uniformity of emphasis upon similarity in both the secular and sacred spheres. As shown, the prevailing literature on Appalachia already posits similarity in the secular sphere. The literature on religion is quite the opposite. An analytical methodology is needed to support the contention of similarity in the sacred sphere. Popular religion accomplishes this.

\section{Definition of Terms and Parameters}

There are three main categories of terminology used here. The major terms, ideas, and concepts used in each need to be defined to avoid confusion and establish clear parameters for the study. First are the terms that are applied primarily to the sacred sphere. Second, the secular realm has its own body of concepts. Of course, there is significant overlap, and so those ideas

\footnotetext{
${ }^{27}$ Lippy, "Popular Religiosity in Central Appalachia," 49.
} 
which can be used to discuss both the secular and the sacred are carefully distinguished and qualified.

This study deals with local and regional church groups while at the same time setting them within a larger, national religious context. On the popular level, much of the terminology connected with one is also used in conjunction with other. But there are times when such conflation is inaccurate. The words "fundamentalism" and "fundamentalist" are excellent examples. Religious historian George Marsden defines "fundamentalists” as "evangelical Christians... who in the twentieth century militantly opposed both modernism in theology and the cultural changes that modernism endorsed." 28 In addition to doctrinal militancy, Methodist scholar Kenneth Collins identifies three other markers of fundamentalism - 1) social ambivalence; 2) sectarianism; and 3) the use "the doctrine of verbal inerrancy as a bulwark against the acids of modernity.",29

American fundamentalism has always cut across denominations. In the early decades of the twentieth century, Baptists, Presbyterians, Pentecostals, and holiness Methodists claimed the mantel of fundamentalism, all though initially fundamentalists were overwhelmingly from Northern urban areas. They responded to a growing theological liberalism by carefully crafting defenses of such paramount issues as miracles and a literal interpretation of the Bible. Theology and a willingness, if not an eagerness, to fight over it bound together what Marsden also calls "a loose, diverse, and changing federation of co-belligerents." ${ }^{30}$

\footnotetext{
${ }^{28}$ George Marsden, Fundamentalism and American Culture (Oxford: Oxford University Press, 2006), 4.

${ }^{29}$ Kenneth Collins, The Evangelical Moment: The Promise of An American Religion (Grand Rapids: Baker, 2005), $36,37$.

${ }^{30}$ Marsden, 4. See also Martin Riesebrodt, Pious Passions: The Emergence of Modern Fundamentalism in the United States and Iran, Translated by Don Reneau (Los Angeles: University of California Press, 1993); Ernest R. Sandeen, The Roots of Fundamentalism: British and American Millenarianism, 1800-1930 (Chicago: The University of Chicago Press, 1970), and Grammich, Local Baptists, Local Politics. Also see all of these on the emergence of
} 
Many rural believers, in Appalachia and in other parts of the country, held similar if not identical beliefs. However, simply calling these Christians fundamentalists and automatically equating them with their Northern city-dwelling co-religionists would be inaccurate.

Fundamentalism may have spread throughout the country, and by the 1920s Christians across America were claiming the title, but fundamentalism was as much a term used to describe adherence to certain traditional interpretations of the Christian faith as it was a movement, and as religious scholar Gary Dorrien notes, fundamentalism is "more elusive as a concept than popular usage implies. ${ }^{31}$

Its emergence in the North was driven by the rising power of theological and religious counter-forces that simply did not exist in other parts of the country at the time. While fundamentalists held beliefs in common with other Christians, the former group understood, approached, and articulated their faith with certain nuances unique to their reaction against theological liberalism. ${ }^{32}$ Thus, while this work will point out the closeness between fundamentalists and Appalachian Protestants, it is careful not to apply the terms "fundamentalist" and "fundamentalism" in ahistorical and thus inappropriate ways. When discussing the militant movement against theological liberalism, those two terms are used. However, when discussing denominations which held beliefs similar or even identical to fundamentalists but which, for

\footnotetext{
the term "fundamentalism" in conservative Protestant circles in America. In contrast to Marsden and others who position the holiness movement at the core of American fundamentalism, Collins sees it as occupying a place closer to the edge. Those churches, he asserts, were indeed affected by fundamentalism and concerns for doctrinal purity, but they were never as militant as Presbyterians or Baptists. The concern for "the inculcation of holy love in the hearts of believers" remained the chief concern for churches such as the Nazarenes and the Wesleyan Methodists, and doctrinal infighting would not be allowed to distract from the pursuit of that goal. In general, soteriological concerns and Anglican roots prevented fundamentalism from becoming a powerful force in the greater Wesleyan tradition, including mainstream Methodism. See Collins, The Evangelical Moment, 36.

${ }^{31}$ Gary Dorrien, The Remaking of Evangelical Theology (Louisville: Westminster/John Knox Press, 1998), 9.

${ }^{32}$ Grammich, 1 . This author argues that "rabid" textual literalism and rationalism underpinned the fundamentalist movement in the early decades of the twentieth century. See Dorrien, The Remaking of Evangelical Theology, 8, 9.
} 
whatever reason, were not as militant, broader and more generic terms are applied, such as conservative or traditional.

Liberalism is another term requiring some clarification. The term has several meanings across the sacred-secular spectrum, but here it is used almost exclusively in a theological context. To help, the phrase "theological liberalism" is also used. Even when the words such as "liberal" or "liberalism" are used alone, the reference, unless otherwise specifically indicated, is to the religious trend that emerged in America in the middle of the nineteenth century, reaching full maturity in the early years of the 1900s.

Liberal theology traces its roots to German thinkers of the eighteenth and nineteenth centuries. Scientific and philosophical developments called into question scriptural and ecclesiastical authorities. Philosophers, theologians, and scholars such as Immanuel Kant, Friedrich Schleiermacher, and G.W.F Hegel saw the need to reconcile Christian thought with these features of modernity (see below for more on modernity). A second generation of Germans, including Ferdinand Christian Baur, David Freidrich Strauss, Isaak August Dorner, and Albrecht Ritschl, focused and systemized these earlier efforts, making theological liberalism into a recognizable and distinct school of thought predicated upon the application of modernity to theology. Liberals asserted the ability and the right of individuals to critically evaluate, interpret, and if necessary change traditional doctrine, thereby questioning the Bible, the Church, and tradition as the absolute and unquestioned source of religious authority. This contributed to an emphasis on practical and religious aspects of the faith. Ultimately, theological liberalism represented the successful attempt to ensure that Christianity would remain a vibrant, relevant, 
and respected force in an age of reason. ${ }^{33}$

The classic work on American liberal theology is Gary Dorrien's three-volume The Making of American Liberal Theology. He convincingly argues that American theological liberalism developed into a bona fide intellectual tradition in its own right. It owed much to German thought, but took these ideas and incorporated them into an existing tradition of American progressive religion. Over the course of the Gilded Age and the Progressive Era, two other forces exerted a powerful influence on American liberal Protestantism - the increasing acceptance of Darwin and rapid industrialization. ${ }^{34}$ However, these three forces did not coalesce to produce a single American liberal Protestant vision. Theologians and preachers made great strides in reconciling evolution and the Bible, and many of them were also committed to serious social reform. However, an American version of liberal theology which concertedly, comprehensively, and coherently dealt with all three factors - Darwin's theory of evolution, German theological liberalism, and rapid industrialization - did not emerge until the rise of social gospel.

The social gospel must not be fully equated with theological liberalism. This work is careful to distinguish between the two. Not all liberals were adherents of the social gospel. Not all reformers were social gospelers either. Therefore, a careful distinction will be made between those reform efforts which were a part of the social gospel and those which were not.

The social gospel was a unique expression of liberalism that was characterized by "its belief that social reform could lead to concrete signs of the kingdom of God in contemporary

\footnotetext{
${ }^{33}$ Stanley J. Greenz and Roger E. Olson, $20^{\text {th }}$ Century Theology: God and the World in Transition (Downers Grove, IL: Intervarsity Press, 1992), 52; Dorrien, The Making of Liberal Theology: Idealism, Realism, and Modernity, (Louisville: Westminster/John Knox Press, 2003), xxiii.

${ }^{34}$ Gary Dorrien, The Making of American Liberal Theology: Imagining Progressive Religion, 1805-1900 (Louisville: Westminster/John Knox Press, 2001), xvii-xx.
} 
social institutions, whether in families, businesses, or governments. ${ }^{35}$ These reformers saw industrialized society as inherently flawed and sought to structurally re-align it with the teachings of Jesus. The concept of the kingdom of God became the single tenant of the faith. Modern science, anchored by Darwinian evolution, should be a means for the advancement of all people, not just a way for the rich and powerful to maintain their privileged position. The theme of unity bound the theory of evolution with the concept of the kingdom. Society, like nature, was an organic whole, not just a composite of atomized individuals. The kingdom of God signified the communion between God and people, both individually and collectively. Therefore, in order to ensure full communion, both the sub-structure and the super-structure of society, not just its occupants, must be radically transformed. They must evolve.

Two of the major analytical terms used here when discussing the secular sphere are "capitalism" and "industrialization." The term "capitalism" is the subject of much discussion. This project is not the place to engage in a detailed discussion about the economic, historical, and philosophical minutia associated with defining that word. For these present purposes, Immanuel Wallerstein's definition is more than adequate, simple, and, if taken at face value, neutral. In World-Systems Analysis, he describes "capitalism" as "a historical system defined by the priority of the endless accumulation of capital., 36

"Industrialization" and related words perhaps need clarification more than definition. As

\footnotetext{
${ }^{35}$ Christopher H. Evans, Liberalism Without Illusions: Renewing an American Christian Tradition (Waco, TX: Baylor University Press, 2010), 55. Evans points out that precise understandings of the term "kingdom of God" varied widely, and a more detailed analysis is given in Chapter 7. Broadly speaking, it refers to the reign and the realm of God. This does not just apply to heaven or to some future state on earth. Throughout church history, Christians have believed that the kingdom is in some sense a present reality on earth, although there has been little consensus on this. For more on the various views of this topics, see Craig C. Hill, In God's Time: The Bible and the Future (Grand Rapids: Eerdmans, 2002).

${ }^{36}$ Immanuel Wallerstein, World-Systems Analysis: An Introduction (Durham, NC: Duke University Press, 2004), 92. Again, following Wallerstein, "capital" is not just the money invested in a particular enterprise, it includes the sum total of the means of production.
} 
is shown, the argument here does not proceed from the presupposition that "pre-industrial" Appalachia existed completely devoid of non-agricultural business enterprises. Rather, the industrialization that took place in the mountains during the late nineteenth and early twentieth centuries was part of a greater industrial shift in America. T.J. Jackson Lears identifies two interrelated characteristics of this "second industrial revolution." First, the level of technology was unprecedented, especially in its ability to overcome nature, and far outpaced, both quantitatively and qualitatively, antebellum industrial development. Second, the second industrial revolution entailed a "shift from the disorganized entrepreneurial capitalism of the earlier nineteenth century to the organized corporate capitalism of our own time." This transition fueled and was fueled by the rise of a national market, which in turn necessitated greater rationalization of resources, production, and labor. ${ }^{37}$ This process, of course, sparked and fueled significant cultural transitions.

Lears's conception of industrialization is the one used here. It is consistent with the current scholarship on Appalachia which shows that the region had some degree of industry prior to 1880 and that it was connected to outside markets to the extent that its geography and level of technological sophistication would allow. In addition to carefully distinguishing between tiers of economic development, Lears's understanding provides easy access to cultural investigation and can help explain the link between economics and culture, including religion.

Just as the secular and sacred spheres overlap, so does the terminology used to analyze and discuss them. Many of the critical terms used in this study can be applied to both secular and sacred subjects, although the meaning changes significantly. The closely related concepts of

\footnotetext{
${ }^{37}$ T.J. Jackson Lears, No Place of Grace: Antimodernism and the Transformation of American Culture, 1880-1920 (Chicago: University of Chicago Press, 1981), 9. See also Richard Franklin Bensel, Political Economy of American Industrialization, 1877-1900 (Cambridge: Cambridge University Press, 2000) for more on the rise of the national market.
} 
modernism and modernization need to be carefully defined because this cluster of words is used in both sacred and secular contexts here, with individual words used exclusively in just one particular setting. While modernism can apply to religion, philosophy, culture, and many other fields, here it is used exclusively in a religious context.

In religious studies, modernity is very closely related to theological liberalism. What is considered "modern" thought emerged in the Enlightenment, as the scientific and philosophical revolutions produced radical changes in the way people viewed themselves and the world around them. In short, modernity challenged authority and established "individual reason and conscience as the primary arbiters of truth and action." ${ }^{38}$ Human beings possessed the ability to reason and should not believe anything not supported by rational evidence. Just as nature operated by uniform and orderly laws which were universal, so did reason transcend time, place, and custom, binding humanity together. Whatever was reasonable represented the true nature of things. That which was unreasonable reflected the ways by which people had departed from the rational path by following superstition, passion, or some other folly. ${ }^{39}$

Liberalism in America had an evangelical heritage and an Enlightenment/modernist heritage. From nineteenth century evangelicalism, liberalism inherited the foundation of the Gospel, the teachings and example of Jesus, and the hope of the Kingdom. Elements of modern thought such as a commitment to "the continuity between reason and revelation, [the] champion[ing of] the values of toleration, humanistic individualism, and democracy" also

\footnotetext{
${ }^{38}$ James C. Livingston, Modern Christian Thought: The Enlightenment and the Nineteenth Century (Minneapolis: Fortress Press, 2006), 6.

${ }^{39}$ Livingston, 7-9. To be clear, while some of the more radical Enlightenment thinkers, such as Voltaire, rejected religion, others, such as John Locke and even Jean-Jacques Rousseau, recognized its importance and continued to adhere to some of the supernatural aspects of Christianity. Locke, along with Bishop Joseph Butler, attempted to employ human reason in the defense of miracles.
} 
constituted principle features of theological liberalism. ${ }^{40}$

Well into the twentieth century, liberals continued to balance these components, although it was not always easy. On the other hand, theological modernism, generally speaking, elevated parts of this heritage over its evangelical stream, taking an even more progressive approach to religion. Reason trumped revelation; historical criticism loosed Christianity from its gospel moorings. Much of this transformation occurred in the first decades of the twentieth century, but Dorrien is clear there were good examples of it to be found in the nineteenth century, both in Europe and America. ${ }^{41}$

Modernization, in contrast, is used to describe the industrial, social, and non-religious cultural changes. Because of the close connection between the religious and non-religious changes, great care is taken to use the term as carefully and specifically as possible. As various scholars have noted, the term is difficult to define. Richard D. Brown posited that modernization described all of those elements - social, cultural, political, economic, legal, technological - that resulted in "movement in the direction of the modern ideal type." 42

But modernization had its critics. There was no single standard definition. The concept was ethnocentric, teleological, and, at least by Brown's definition, tautological. Scholars such as Peter N. Stearns and Raymond Grew maintained that while as an overarching framework modernization had its problems, the term should not be completely discarded. On the contrary, it should be applied as discretely and narrowly as possible to show how adaptation occurred in

\footnotetext{
${ }^{40}$ Gary Dorrien, The Making of American Liberal Theology: Idealism, Realism, and Modernity , 1900-1950 (Louisville: Westminster John Knox Press, 2003), 10, 11.

${ }^{41}$ Dorrien, $10-20$.

${ }^{42}$ Richard D. Brown, Modernization: The Transformation of American Life, 1600-1865 (New York: Hill and Wang, 1976), 8 .
} 
particular places in response to particular catalysts. ${ }^{43}$

In light of these difficulties, perhaps it is better to use modernization more descriptively than analytically. Modernization occurred in the mountains between 1880-1920, but as recent scholarship on Appalachia points out, modernization was already underway. ${ }^{44}$ For these purposes here, then, modernization will refer to the whole process of the region assimilating into the dominant culture. The process and the results include social, cultural, technological, political, and religious categories and extend from the highest reaches of government and business to the most intimate details of family and personal life, even into individual perceptions and understandings of the world. This may seem overly simplistic, but keeping it simple is the point. The purpose here is to show how a multiplicity of factors affected a specific group of people at a specific time and how they responded to those forces. These people were both passive and active. Their agency must not be lost in what appears, perhaps even here, to be an inevitable and overwhelming impersonal flood. The story here is of the interplay between the agency of various groups of people. Those working for modernization, for whatever reason, used the term as a description of reality, not as an analytical framework for it.

\section{Chapter Overview}

This work is arranged both thematically and chronologically. The chapters fit together thematically, with each individual chapter developing chronologically. After the Introduction,

\footnotetext{
${ }^{43}$ See, among others, Raymond Grew, "More on Modernization," Journal of Social History 14 (Winter 1980): 179187 and Peter N. Stearns, "Modernization and Social History, Some Suggestions and a Muted Cheer," Journal of Social History 14 (Winter 1980): 189-209. See also the more recent AHA roundtable on modernity and the related concepts of modernism and modernization "Historians and the Question of 'Modernity'," The American Historical Review 116 (June 2011): 631-751.

${ }^{44}$ See in particular Dwight B. Billings and Kathleen M. Bless, The Road to Poverty: The Making of Wealth and Hardship in Appalachia (Cambridge: Cambridge University Press, 2000); Wilma A. Dunaway, The First American Frontier: Transition to Capitalism in Southern Appalachia, 1700-1860 (Chapel Hill: The University of North Carolina Press, 1996); and Kenneth W. Noe, Southwest Virginia's Railroad: Modernization and the Sectional Crisis (Urbana-Champaign: University of Illinois Press, 1994). These authors do not agree exactly on when modernization occurred in Appalachia. They all, like Lewis, do point out that Appalachia was not a remote, isolated, and backwoods region completely cut-off from the rest of the country prior to the Gilded Age.
} 
Chapter 2 provides a broad background to West Virginia sacred and secular life between 1865 and 1880. The chapter is divided into two major sections, one covering the secular sphere and the other the sacred. Each of these is in turn divided into two sections, one over-viewing statewide developments and the other focusing just on the history of the five counties under examination here. This chapter sets the Allegheny region into state, regional, and national contexts. It lays the foundation for showing the cultural, economic, and religious connections between the mountain counties and the rest of the state and country. By pointing out key basic similarities, it sets up later chapters to show the continuity and change of the Gilded Age and Progressive Era.

Building on the framework of Chapter 2, Chapter 3 looks at industrialization in five mountain counties - Mineral, Grant, Tucker, Randolph, and Pocahontas - from 1880-1920. Admittedly, this is a broad topic. Thus, the focus here is chiefly on the railroad and the other developments it spawned. The chapter traces the path of the steel rail as it headed south from near the Maryland border and drove deep into the mountains. In the process, it facilitated an explosion in timbering, mining, and associated manufacturing industries. These were not the only changes brought by rail. The very localized transportation revolution caused social and political upheaval. These were more quantitative than qualitative, but the rapidity with which the changes occurred amplified their severity. Through the latter half of the nineteenth century, West Virginia stood poised to take a leading role in a modern industrial nation, thanks in large part to the natural resources harvested in the Alleghenies. By 1920, the highlands, and West Virginia in general, were fully incorporated into an America that saw itself at the forefront of civilization.

Chapters 4-6 delve deep into mountain religious life. Each chapter deals exclusively with a distinct Protestant denomination - chapter four treats the Methodists, chapter five the 
Presbyterians, and chapter 6 the Baptists. The chapters are not distinctly comparative, although there are aspects of comparison among the three groups. Rather, the primary focus is on the growth and mission work of each denomination within the region, as well as the character of belief, polity, and worship. Local, state, and national church and denominational records provide the data needed to reconstruct religious life in the mountains.

Chapters 7 and 8 build on the specific local Christian activities detailed in the previous three chapters. They form links between this material and the broader religious and cultural developments occurring in the country between 1880 and 1920. Chapter 7 focuses on how the churches in the region dealt with the two major religious developments of the period fundamentalism and the social gospel. Chapter 8 ties the secular and sacred together by examining how moral reform causes, specifically temperance and Sabbath-keeping, helped assimilate the mountain region of West Virginia, and by extension the state as a whole, into contemporary mainstream American culture. In doing so, it demonstrates how local churches served as cultural mediators between highland communities and the rest of the country.

The conclusion reiterates the argument constructed throughout the work, emphasizing religion's role in drawing West Virginia into the contemporary American mainstream. Industrialization, spearheaded by the railroad, created an environment of constant change. The material reality of industrialization was itself a change and a determining factor in how mountain society would respond to and evolve from the introduction of new technology. However, of equal if not greater significance was the mentality that undergirded industrialism and the subsequent importance assigned to it. Thus, the railroads brought not only advanced means of production in the form of factories, mills, and mines, but also a particularly refined vision about the greater purpose of these improvements for society and culture as a whole. 


\section{2: The Secular and Sacred in Reconstruction Era West Virginia: An Overview}

\section{Introduction}

Faith permeated West Virginia from its birth. Sacred and secular forged strong bonds as people worked to rend the tethers of the Old Dominion. While not chronically disloyal, the people of the transmontane had diverged culturally and socially from the east in important ways. The rugged terrain of western Virginia precluded the widespread use of slaves and the formation of a slave society as developed in the Tidewater and Piedmont. The western portion was still primarily agricultural, but the state founders believed their future lay with the North, not the South. In his inaugural address, Governor Arthur I. Boreman reiterated the long-standing and ever-growing division between East and West in the Old Dominion. "Our markets, our trade and our travel are North and West of Virginia, through natural channels, or those constructed through the enterprise of our own people, or such means as they could procure," he argued. ${ }^{1}$

Thus, as historian Ronald L. Lewis explains, "Economic development was neither a new concept, nor was it imposed on the West Virginians by 'outsiders'."2 The founders of the new state had a distinct vision for West Virginia. They adopted what historian John Alexander Williams calls the "development faith." Northern economic might resulted from industry fueled by a dynamic capitalism and a business-friendly government. A Union victory in the Civil War meant that this type of political economy would control the entire nation, whether the South liked it or not. ${ }^{3}$ The Republicans who severed West Virginia from the Old Dominion and held power

\footnotetext{
${ }^{1}$ Arthur I. Boreman, "Inaugural Address," in West Virginia: Documents in the History of a Rural-Industrial State, Ronald L. Lewis and John C. Hennen, eds. (Dubuque, IA: Kendall/Hunt Publishing, 1996), 99.

${ }^{2}$ Ronald L. Lewis, Transforming the Appalachian Countryside: Railroads, Deforestation, and Social Change in West Virginia, 1880-1920 (Chapel Hill: The University of North Carolina Press, 1998), 57.

${ }^{3}$ Eric Hobsbawm, The Age of Capital: 1848-1875 (New York: Vintage Books, 1975), 140, 141. See also Richard F. Bensel, Yankee Leviathan: The Origins of Central State Authority: 1859-1877 (Cambridge: Cambridge University Press, 1999).
} 
in the state through the 1860 s believed their state could be a leader in the post-war nation. Large reserves of natural resources would drive the creation of a well-capitalized industrial state able to compete with the eastern states. Separating from Virginia and building the state on

fundamentally different economic and political principles was a giant first step toward this goal. ${ }^{4}$

This basic economic stance was not the only way in which the new state positioned itself to be at the forefront of late nineteenth century American society. The statemakers believed that economic growth would lead to moral and social improvement. ${ }^{5}$ In fact, religion played a prominent role in public political life throughout the 1860s. Led by anti-slavery Methodist Protestant and army chaplain Gordon Battelle, fourteen preachers or lay exhorters attended the West Virginia Constitutional Convention. Twenty-nine clergymen served in the state legislature between 1863 and $1872 .^{6}$ Francis H. Pierpont, a leading advocate for a new state and governor of the restored state of Virginia which permitted the western counties to leave, was a devout Methodist Protestant layman. Waitman T. Willey, one of West Virginia's first two senators, was an active Methodist Episcopal layman.

Methodists (MP and MEC in particular) actively engaged in statehood politics from the 1840s through the 1860 s. Their specific contributions are well documented. The circuit-riding tradition helped familiarize Methodist clergy with the area and its inhabitants, and many proUnion Methodist served as scouts and recruiters for the army. The early 1870s witnessed an anticlerical backlash, and Protestant ministers, particularly Methodist ones, gradually disappeared

\footnotetext{
${ }^{4}$ John Alexander Williams, "The New Dominion and the Old: Ante-Bellum and Statehood Politics As the Background of West Virginia's 'Bourbon Democracy'," West Virginia History 33 (Jan. 1972), 348-352. See also Lewis, 57-60.

${ }^{5}$ Williams, “The New Dominion,” 352.

${ }^{6}$ Williams, "The New Dominion,” 344, 345.
} 
from the legislature. Democrats gained control of the government in 1870, and former Confederates and those opposed to statehood dominated the 1872 Constitutional Convention. They blamed Methodists and Republicans, usually one and the same, for Yankee success and repressive anti-Confederate policies of the 1860 s. $^{7}$ Baptist and Presbyterian activity during the same period is significantly more obscure and less well documented.

Nevertheless, the connection between secular and sacred remained. Throughout the 1870s, adherents of the development faith continued efforts to transform West Virginia into a manufacturing state and take its rightful place at the head of an industrial America. State political and economic leaders wanted to strengthen West Virginia's ties to the North and East, thus further distancing the state from its agrarian roots. This economic vision coupled with the dominant mainline Protestant culture in the state meant that a strong foundation was in place for fully incorporating West Virginia into the industrial-capitalist culture that would come to dominate the United States around 1880.

Secular - West Virginia

West Virginia Republicans faced quite a challenge in ensuring that not only would their vision for the state prevail, but that they would remain in power to guide development. For a variety of reasons, much of the state did not share their outlook. A sizable minority were exConfederates and Southern sympathizers. Many of the citizens of the new state had not wanted to leave the old one. Furthermore, most of the state was not in a position to enjoy the fruits of industrialization. The state developed unevenly; nearly half of all manufacturing jobs in the state were in the northern panhandle as late as 1880 . The overwhelming majority of the state was agricultural, and what industry existed outside the northern-most counties was primarily

\footnotetext{
${ }^{7}$ Williams, "The New Dominion," 354, 346; See also Matthew Foulds, "Enemies of the State: Methodists, Secession,
} and the Civil War in Western Virginia, 1845-1872” (PhD diss., The Ohio State University, 2012$)$, ProQuest 3521017. 
extractive - coal, salt, and timber. Nearly all of the industries which used or refined natural resources, such as glass works or steel mills, were in just four panhandle counties. ${ }^{8}$

Political realities remained closely related to economic realities. Democrats had strong support among farmers, especially in the southern part of the state. In addition, ex-Confederates sought to re-gain political power and continue to keep blacks out. Republican policies in the 1860s did little to win over large sections of the electorate. In the 1870 election, Democrats swept back into power, taking over the legislature and the governor's office. They also put candidates in both houses of Congress. The state legislature called a constitutional convention to make some changes in the "Yankeefied" document of 1863. Republicans won only twelve seats at the convention; there were only five ministers. Nearly half of the seventy-eight delegates were lawyers; twenty were farmers and seventeen were businessmen. ${ }^{9}$

Democrats controlled state politics for more than twenty years. Throughout the last three decades of the nineteenth century, four major factions vied for control of the party and the state Redeemers, Agrarians, Regulars, and the Kanawha Ring. Within these larger groups various rivalries emerged. The Regulars, for example, were led by Johnson N. Camden and Henry G. Davis. Both were leading developers of the railroad into the interior of the state. Born in Lewis County in what is now central West Virginia, Camden pioneered the oil industry in the state and then moved to coal. A Maryland native, Davis was a prominent figure in the North-Central coalfields. He was also the first Democrat from the state elected to the United States House of Representatives, having previously served in the West Virginia state senate. Camden and Davis at times clashed over political and business affairs, which meant that while the Regulars tended

\footnotetext{
${ }^{8}$ Ken Fones-Wolf, Glass Towns: Industry, Labor, and Political Economy in Appalachia, 1890-1930s (Urbana: University of Illinois Press, 2007), 62.

${ }^{9}$ Lewis, 104, 105.
} 
to be the dominant faction, internal struggles coupled with other current events in West Virginia politics meant that two of the other groups of the state Democratic Party could block the industrialist wing. Thus, no one single group was able to completely control the party during the late nineteenth century. ${ }^{10}$

As a result of the internal squabbles, Democratic rule did not necessarily mean a change in overall economic direction for West Virginia. Many in the Democratic Party exhibited a faith in the railroad as the engine of that hoped-for economic future. ${ }^{11}$ Thus, the development faith had bi-partisan support. The only question was exactly how to practice that faith. West Virginia Republicans supported their party's pro-tariff position. West Virginia Democrats, on the other hand, split on the issue. Tariffs would help the industries of the state, coal in particular. Industrial Democrats such as Davis and Camden came to support the tariff because it would benefit them financially and strengthen their position in the state. Other Democrats, the Agrarians in particular, tended to support the traditional national Democratic position of low tariffs, in addition to tighter state regulation of railroads and other industries. ${ }^{12}$

Despite being out of power in West Virginia for most of the late nineteenth century, Republicans were not without able statesmen. Many of those were also leading businessmen. John Alexander Williams identifies Nathan B. Scott and Stephen B. Elkins as the two most prominent Republican industrialists/politicians of the late nineteenth century and early twentieth century. ${ }^{13}$ From Wheeling, Scott was a glass manufacturer also involved in mining and banking.

\footnotetext{
${ }^{10}$ Williams, "The New Dominion," 363; John Alexander Williams, West Virginia and the Captains of Industry (Morgantown, WV: West Virginia University Press, 2003), 1-17; Thomas Richard Ross, Henry Gassaway Davis: An Old Fashioned Biography (Parsons, WV; McClain Printing Company, 1994), 46.

${ }^{11}$ Lewis, 105.

${ }^{12}$ Williams, West Virginia and the Captains of Industry, 18, 19.

${ }^{13}$ Williams, 3. Elkins will be covered in greater detail below. For more on Scott, see Fones-Wolf, Glass Towns.
} 
Elkins originally hailed from Missouri, but moved to New Mexico after the Civil War. He married H.G. Davis' daughter Hallie and moved to West Virginia in the 1870s, becoming a partner in his father-in-law's business ventures.

Throughout the latter half of the nineteenth century, much of West Virginia remained agricultural, but this did not mean it was isolated from the rest of the country. Because of their positions along important tributaries, cities such as Morgantown, Wheeling, and Charleston became commercial centers, connecting the more remote interior with the rest of the country, allowing agricultural products to come out and finished goods to come in. But relatively small amounts of capital, rugged terrain, and lack of transportation meant that most of the available capital was invested in areas with the easiest access to larger cities such as Pittsburgh or Cincinnati. In the antebellum period, for example, salt mining became a major industry in the Kanawha Valley, and Francis H. Pierpont led a group of investors in forming a mining company in the Monongahela Valley. ${ }^{14}$

Some entrepreneurs made efforts to charter companies in the interior, but the lack of more rapid means of transportation than the river represented a significant obstacle to profitable development. The $\mathrm{B} \& \mathrm{O}$ had cut across the northern part of the state before the Civil War. By 1873, the Chesapeake and Ohio Railroad cut across the southern-central region, including the state capital of Charleston, helping to open up the southern coalfields and connect Richmond with the Ohio River. ${ }^{15}$ Aside from the few spurs of each mainline, the interior of the state lay

\footnotetext{
${ }^{14}$ Lewis, 51; Wilma A. Dunaway, The First American Frontier: Transition to Capitalism in Southern Appalachia, 1700-1860 (Chapel Hill: The University of North Carolina Press, 1996), 146-155; Ronald L. Lewis, "Industrialization," in High Mountains Rising (Chicago: University of Illinois Press, 2004), 61; Barbara Rasmussen, Absentee Landowning \& Exploitation in West Virginia, 1760-1920 (Lexington: The University Press of Kentucky, 1994), 70.

${ }^{15}$ Cicero Fain, "Into the Crucible: The Chesapeake and Ohio Railroad and the Black Industrial Worker in Southern West Virginia, 1870-1900,” Journal of Appalachian Studies 17 (Spring and Fall 2011), 49.
} 
beyond the reach of the Iron Horse. Thus, before 1880, much of the state lacked the means to industrialize and diversify economically. Geography discouraged local elites from developing the interior and mountain regions. The major railroads were also not willing to take the risk of laying tracks over the mountainous and hilly terrain, but they were willing to cooperate with those who would. ${ }^{16}$

Davis and Camden took the lead in developing these feeder lines. At times, their efforts brought them into more conflict with each other, fueling their political rivalry, even as they attempted to cooperate. Starting from his home in Mineral County near the Maryland border and the B\&O mainline, Davis built his first railroad south through the Allegheny mountains. Those efforts will be discussed in more detail below. He and Elkins also teamed up with Camden to develop land deep in the interior of the state. In 1879, the trio purchased the vast Caperton tract in central West Virginia. ${ }^{17}$

The year before, Camden was elected president of the Clarksburg, Weston, and Glenville Railroad and Transportation Company. The C.W.\& G. incorporated in 1878 and evolved out of another railroad, the Weston and West Fork. The goal of these lines was to link the interior of the state to the B\&O mainline in Clarksburg. Prior to the Civil War Camden had struck oil in central West Virginia and concentrated on refining oil after the war. In the 1870 s he sold his operation to Rockefeller's Standard Oil, but he and his associates retained control of the company. Thus, he was intimately involved in and acquainted with early industrial development in the state. His brother and uncle were both involved in the W. \& W. F. so Camden also had strong connections

\footnotetext{
${ }^{16}$ Lewis, 67.

${ }^{17}$ Williams, West Virginia and the Captains of Industry, 6.
} 
with transportation developments in central West Virginia. ${ }^{18}$

Through the late nineteenth and early twentieth centuries, Johnson N. Camden became to central West Virginia what H.G. Davis was to the highlands. While Camden resigned his position with the railroad in 1881 after being elected to the United States Senate, he continued to be heavily involved in opening up the region and connecting it to key points in all directions. Throughout the 1880s he purchased land and spearheaded efforts to generate capital for a number of railroad projects. Anyone wishing to construct a route through central West Virginia came to Camden for help. A couple of especially ambitious plans called for laying track from the Ohio River to the Chesapeake and Ohio mainline in the Shenandoah Valley. ${ }^{19}$

By 1890, a single railroad had emerged as the dominant route in central West Virginia. The West Virginia and Pittsburgh (not to be confused with the West Virginia Central and Pittsburg) formed out the merger of two other railroads - the Buckhannon and Holly River Rail Road and the Clarksburg, Weston and Midland Railroad. All of these were themselves the products of various mergers. Camden was elected president of the new WV\&P and worked to extend the line as much as possible, even to the point of possibly competing against Davis's enterprise. $^{20}$

Going through Upshur and Webster County, the line penetrated into remote southwestern Randolph County. Another prominent state Democrat, John T. McGraw, offered Davis the possibility of meeting the $\mathrm{C} \& \mathrm{O}$ in Pocahontas County. McGraw owned land in Marlin's Bottom, and knew that the $\mathrm{C} \& \mathrm{O}$ was planning a route through the Greenbrier Valley. He wanted

\footnotetext{
${ }^{18}$ Alan R. Clarke, The West Virginia and Pittsburgh Railroad: The B\&O's Road to the Hardwoods (Charleston, WV: Quarrier Press, 2008), 18-21. For more on Camden, see Williams, West Virginia and the Captains of Industry.

${ }^{19}$ Clarke, The West Virginia and Pittsburgh Railroad, 28-45.

${ }^{20}$ Clarke, The West Virginia and Pittsburgh Railroad, 53, 54.
} 
Camden's road to meet the $\mathrm{C} \& \mathrm{O}$ around his property. In preparation for industrial development, McGraw helped lay out a new town named Marlinton. ${ }^{21}$ While the WV\&P opened up central West Virginia, importing industry and progress and exporting coal and timber, it never penetrated into the heart of the Allegheny highlands. Although he did not get as far was he wanted, laying track in the Greenbrier Valley would be the final act in Davis's conquest of the high country. There were many obstacles, both natural and man-made, that Davis had to overcome first. The Iron Horse would steam through the mountains, but it would take considerable time and effort. Secular-Alleghenies

The Allegheny Mountains held great promise for industrialists and entrepreneurs. They also presented a great challenge. Although not as extensive as those in the southern part of the state, the coal deposits in the northern and eastern mountains were considerable. The mountains also had vast virgin tracks of hardwood and spruce. Davis saw an opportunity to connect the sizable natural resources of the West Virginia interior with the markets in the East. He was in the perfect position to take advantage of the situation. While he maintained a residence in Maryland, his official home, for political purposes, was Piedmont, in Mineral County, West Virginia. Before the Civil War, Davis got his start on the railroad working the B\&O engine house in that town. ${ }^{22}$

Mineral County was the most developed county in the Allegheny region in the immediate post-war period. According to the 1860 Census, the level of industrialization exceeded that of the rest of the South but still fell below the Midwest and the nation as a whole. On the other hand, the other counties examined here were considered "laggard counties," falling behind even average southern development. In a portent of things to come, the railroad spurred this

\footnotetext{
${ }^{21}$ Clarke, The West Virginia and Pittsburgh Railroad, 60-77. In 1899, Camden sold the WV\&P to the B\&O. He remained president of the West Virginia and Pittsburgh Division of the B\&O.

${ }^{22}$ Ross, 25, 38 .
} 
development. The Baltimore and Ohio Railroad cut through the northern tip of the county and turned Piedmont and what became the town of Keyser into small hubs of commerce, although Piedmont remained unincorporated until after the war. The Davis family owned property across the county, which in 1866 Henry G. had helped sever from Hampshire County. He also played a role in founding New Creek, which in 1874 changed its name to Keyser after the Vice-President of the $\mathrm{B} \& \mathrm{O}$, the county seat. Calling upon his own employment experience with the $\mathrm{B} \& \mathrm{O}$ before the Civil War, recognizing the vast natural wealth of the Alleghenies, and realizing his proximity to the $\mathrm{B} \& \mathrm{O}$ afforded him an incredible business opportunity, Davis, along with his two brothers, formed a railroad company in 1866 - the Potomac and Piedmont Coal and Railroad Company. The charter of incorporation granted the company permission to extend track south from the mainline of the $\mathrm{B} \& \mathrm{O}$ into Mineral, Grant, Tucker, and Greenbrier County. The Davis railroad was the first of many chartered to go over the mountains to the West Virginia interior. However, for various reasons he delayed construction for almost fifteen years. ${ }^{23}$

In the meantime, Davis began inspecting, buying, and leasing coal property throughout Mineral and neighboring counties, both in Maryland and West Virginia. He also took the time to scout out the timber resources of the area. While much of Mineral County had been cut over, there was still some valuable timber land in the southwestern part of the county along the Maryland border. ${ }^{24}$ Mineral County, along with Grant and Tucker counties to the southwest, comprised the Upper Potomac coal field. Most of this field lay untapped through the 1870s. But Mineral County, due in large part to the $\mathrm{B} \& \mathrm{O}$, was the third largest coal-producing county in the state in 1870 . While its production declined significantly over the course of the decade, Mineral

\footnotetext{
${ }^{23}$ Alan Clarke, The West Virginia Central and Pittsburgh Railway: A Western Maryland Predecessor (Lynchburg, VA: TLC Publishing, 2003), 3-6; Ross, 40.

${ }^{24}$ Ross, 53; Henry Gassaway Davis, “Journal,” Sept. 20, 1877.
} 
County became the center of operations in the early years of the Davis industrial empire, although his mining and timbering operations were certainly not the only ones in the county or the region. ${ }^{25}$ Looking to extend his holdings, Davis made trips to Randolph and Barbour counties examining timber stands and coal veins. The former county belonged to what became known as the Elkins coal field, while the latter was in the Fairmont coal field. Initially, he was not impressed, but that would change. ${ }^{26}$

While still delaying major railroad construction, perhaps in part due to the strike of 1877 which started on the B\&O in Martinsburg, Davis began building mills, mines, and coke ovens in Mineral County and western Maryland, using small tramroads to bring raw materials to factories. Yet in the midst of early industrial development, agriculture continued to thrive. Easy access to large eastern markets resulted in higher prices for produce and livestock. At the same time, profits from selling land to logging and mining companies further helped local farmers, and many opened small sawmills. ${ }^{27}$

Through the 1870s, Mineral County led the way in economic development and diversity among counties in the Allegheny highlands. The four other counties in this study - Grant, Randolph, Tucker, and Pocahontas - remained almost exclusively agrarian. The railroad had yet to penetrate them, and natural resource extraction remained very limited, carried out primarily by farmers in order to acquire cash. Antebellum roads and rivers constituted the only means of transportation. ${ }^{28}$

\footnotetext{
${ }^{25}$ Michael E. Workman, Paul Salstrom, and Philip Ross, Northern West Virginia Coal Fields: Historical Context (Morgantown, WV: Institute for the History of Technology and Industrial Archeology, 1994), 66, 67.

${ }^{26}$ Clarke, 4; Workman, et al, 3, 91 .

${ }^{27}$ Gilbert Gude, Where the Potomac Begins: A History of the North Branch Valley (Cabin John, MD: Seven Locks Press, 1984), 102.

${ }^{28}$ Dunaway, 159.
} 
Like Mineral County, Grant County was created after the war. Carved from Hardy County in 1866, Grant County's founders intended it to facilitate the extension of Davis's rail lines to the south and through the mountains. The South Branch of the Potomac River ran through Petersburg, the county seat, located in the southeastern part of the county near the line with Hardy County. The river meant that, even before the split, the eastern and central portions of what became Grant County were relatively well-connected to economic systems in the eastern panhandle and northern Virginia. These areas of the new county contained rich farm land, and by the 1870 s companies had removed much of the timber. The more mountainous northwestern part of Grant County, however, remained largely forested and its coal reserves untapped.

Davis biographer Richard Ross points out that by separating Mineral and Grant counties from their parent counties, Davis helped create two new political entities that were more amenable to industrialization. Even with the $\mathrm{B} \& \mathrm{O}$ depots, large farmers dominated Hampshire County. Hardy County remained isolated from industrial capitalism as well. While agriculture still constituted a significant part of the Mineral and Grant economies, the farmers there were not as politically or economically powerful as they were in the older counties. ${ }^{29}$ Davis had enough to worry about with the mountains; he did not need obstinate landowners standing in his way. It took almost two decades for Davis to reap full advantage from his early political maneuvers. However, the proposed route contained good timber and coal. Davis took great care to ensure that his line always ran through or near the areas with the best natural resources - in terms of both quantity and quality.

The other three counties examined here - Tucker, Randolph, and Pocahontas - had no shortage of natural resources. Throughout the 1870s, all three remained overwhelmingly

\footnotetext{
${ }^{29}$ Ross, 38. For more on Grant and Hardy counties, see E.L. Judy, History of Grant and Hardy Counties, West Virginia (Charleston, WV: Charleston Printing Company, 1951).
} 
agricultural. All three were overwhelmingly mountainous. Tucker County was the third and southern-most county in the Upper Potomac Coal field. Vast coal veins lay beneath the surface, completely untouched, and a sea of virgin timber stood on top. Through the 1870s various absentee investors and speculators acquired thousands of acres. Davis was among them, making trips through the county, buying land and scouting routes for his railroad. ${ }^{30}$

The geography of Tucker County, the smallest of the counties studied here, played a major role in economic development before 1880. The county encompasses several peaks well over 3000 feet and a few over 4000 feet. While the valleys are fertile, they are narrow. ${ }^{31}$ Thus, the terrain did not permit extensive farming of cash crops. High mountains and narrow valleys did not mean Tucker County completely avoided the social structure of more developed places. Through the 1870s, landholding was relatively widespread, but a local elite comprised of just a few families did exist. The Parsons and Minear families in particular played crucial roles in guiding the political and economic direction of the county. ${ }^{32}$

The Minears were among the first settlers of the county. They founded St. George, which became the county seat, in 1776. The leader of the group, John Minear, built the first sawmill west of the Alleghenies, bringing the irons over the mountains on horseback from Moorefield. ${ }^{33}$ Over the next century, a number of saw mills sprang up along the Cheat River, but most of the timber harvested came in response to immediate demand and was consumed locally. Prior to the railroad, the river controlled the flow of trade. The Cheat runs north through St. George and up

\footnotetext{
${ }^{30}$ Workman, et. al. 64-66; Rasmussen, 54-55; The West Virginia Central and Pittsburgh Railway, 3; H.G..D., “Journal," Nov. 9, 1874.

${ }^{31}$ Homer Floyd Fansler, History of Tucker County, West Virginia (Parsons, WV: McClain Printing Company, 1962), $10-26$.

${ }^{32} \mathrm{Hu}$ Maxwell, History of Tucker County, West Virginia (Kingwood, WV: Preston Publishing Company, 1884), 33.

${ }^{33}$ Fansler, 423-426.
} 
to Rowlesburg in Preston County. Those selling timber outside the immediate area or outside the state rafted logs down the Cheat and its tributaries to the B\&O depot at Rowlesburg. ${ }^{34}$

In many ways, the situation in Randolph County was similar. However, as the largest county in the state it was much more vast than Tucker, Grant, or Mineral. Its topography varied significantly as well. The Tygart Valley, for example, which ran on a north-south axis through much of the county, outsized any valley in Tucker County. The soil was fertile enough, although often poorly drained. In addition to crop production, farmers also raised livestock. ${ }^{35}$ Randolph County was well-suited for both cattle and sheep, with mountain pasture lands used for summer grazing. Those farmers who were not also ranchers rented their highlands to livestock men who drove cattle over the Staunton-Parkersburg Turnpike, which ran through the Tygart Valley, before being shipped to larger eastern markets, where they competed well with southern and western beef into the 1880 s. $^{36}$ Harvesting timber offered another option for raising cash and making a living, especially as crop and cattle prices fell in the 1870s. Records do not indicate who built the first sawmill in the county or when, but by 1878 a steam sawmill operated at Dry Fork in the northern part of the county near the Tucker line. ${ }^{37}$

Despite the turnpike, the Tygart Valley remained sparsely populated prior to 1880 . The county seat of Beverly was the largest town and the hub of political and economic power. Most of the larger landholders had tracts around Beverly. Others, such as Confederate veteran Elihu Hutton, held land further up the valley. Still others owned property down the valley around the

\footnotetext{
${ }^{34}$ Lewis, 38, 39.

${ }^{35} \mathrm{Hu}$ Maxwell, The History of Randolph County, West Virginia (Morgantown, WV: The Acme Publishing Company, 1896), 277.

${ }^{36}$ Workman, et. al., 93, 94; Lewis, 32-34.

${ }^{37}$ Maxwell, 300.
} 
tiny community of Leadsville. Small hamlets such as Leadsville dotted the valley and the surrounding mountains. No records exist of coal mining before 1880. As mentioned before, H.G. Davis was initially unimpressed by what he found. Because of this, he only slowly acquired land. Nevertheless, Randolph stood between him and the rest of the Elkins coalfield, the virgin forests of Pocahontas County, and the $\mathrm{C} \& \mathrm{O}$ in Greenbrier County. At first, he was not sure where to buy land, but he knew he had to do so in order to complete his line.

Unlike the other counties studied here, Pocahontas County contained very small amounts of coal. ${ }^{38}$ The mineral would play no significant role in the county's growth between 1880 and 1920 nor would coal be a factor in industrial planning in the 1870s. Nevertheless, Davis's desire to get there was well-founded. Virgin forests covered the county, and the timber industry exercised tremendous influence over the course of events in the county.

The completion of the $\mathrm{C} \& \mathrm{O}$ in the 1870 s opened up possibilities. The mainline ran through southern Greenbrier County and was still a considerable distance from the county line, but the Greenbrier River enabled men to raft logs down to the $\mathrm{C} \& \mathrm{O}$ at Ronceverte, so investors began buying land in southern Pocahontas County. One of the most prominent of these absentee speculators was Col. Cecil Clay, a Union Army veteran from Pennsylvania. Clay led a group of men buying land in Greenbrier and Pocahontas counties. They formed the Greenbrier Lumber Company in 1870, and Clay soon merged his private holdings with the company. The next year the same group organized the St. Lawrence Boom and Manufacturing Company and folded Greenbrier Lumber into it. ${ }^{39}$ Thus, there was an absentee presence in Pocahontas County before heavy industrialization. Smaller, local logging operations were also prevalent. John Yeager built

\footnotetext{
${ }^{38}$ Workman, et. al., Maps 1 and 2.

${ }^{39}$ Roy B. Clarkson, On Beyond Leatherbark: The Cass Saga (Parsons, WV: McClain Printing Company, 1990), 9-10.
} 
the first sawmill in the northeastern end on Allegheny Mountain in 1825. The path of the Staunton-Parkersburg Turnpike came over this mountain, entering what is now West Virginia. It proceeded to what is now Bartow, then north through Durbin, and then over Cheat Mountain to Randolph County. ${ }^{40}$

Topography and the route of the turnpike shaped the course of the county before heavy industrialization. Huntersville, the county seat at the time, was located in the southern end of the county. As usual, most of the county elites and larger farmers lived in or around the county seat. The small communities of Hillsboro, Marlin's Bottom, and Edray each lay within a few miles of Huntersville. All were near or along the Greenbrier River. Frost and Durbin, both below Allegheny Mountain, were the two primary towns in the northern end of the county. All of these towns were small, consisting almost exclusively of farming families. A few other even smaller settlements existed in the middle of the county, but high mountains and rugged terrain effectively split the county in two. ${ }^{41}$

In addition to farming and logging, landholders in both ends of the county engaged in cattle ranching. As in Randolph County, the mountains provided good summer grazing for herds. Apparently, the area around Huntersville was particularly well-suited for livestock. From that end of the county, drovers pushed cattle to Lewisburg, the county seat of Greenbrier County, and then to Covington, Virginia. From there they were shipped via rail to Richmond.

Antebellum accounts also indicate selling cattle helped provide what little cash residents had, but also what little they needed. ${ }^{42}$ This was not necessarily solely subsistence farming, but rather an

\footnotetext{
${ }^{40}$ William Price McNeel and Jane Price Sharp, eds. History of Pocahontas County, West Virginia, 1981: Birthplace of Rivers (Marlinton, WV: Pocahontas County Historical Society, 1981), 156-159.

${ }^{41} \mathrm{McNeel}$ and Sharp, 64-73.

${ }^{42}$ Lewis, 33-34.
} 
example of close-knit communities not wholly dependent on the presence of cash to thrive but still aware of alternative means of making a living. Such communities existed throughout these five mountain counties; indeed, they were prevalent throughout West Virginia into the 1880 s. $^{43}$

The willingness of West Virginians, both in the highlands and in the interior, to economically diversify, along with the early affinity among state leaders for the "development faith," paints a nuanced and complex picture of pre-industrial West Virginia. Many Appalachian scholars now reject the popular notion of a region isolated from the rest of America and wholly unattached to the capitalist market economy of late nineteenth century America. Some of the details about the mountain counties presented here show that locals did engage the national economy and were ready, willing, and able to ship natural resources as well as livestock and produce to larger eastern markets.

Historian Wilma Dunaway applies the concept of world systems to the debate about the evolution of mountain economies. Using that multi-disciplinary analytical approach, she builds upon and moves beyond those scholars who see capitalism present in Appalachia before the Civil War and even the Revolutionary War. Like the rest of southern Appalachia, West Virginia was on a continuum of economic development in the United States that had existed since the colonial period. In its never-ending quest for markets and materials, capitalism continually selfreplicates, producing various zones at different stages of maturity. The major urban centers of capital and commerce constitute the "core." The initial exchange of manufactured goods and raw material occurs at the "semiperiphery," which are usually urban areas as well. The raw materials come from the "periphery." Beyond these lay frontiers into which capitalism has yet to

\footnotetext{
${ }^{43}$ Rasmussen, 53, 54.
} 
penetrate but which it will seek to incorporate, making them into periphery regions. ${ }^{44}$

To be sure, the zones are not so stratified as to preclude some overlap. In fact, while this system is useful for macro-analysis, it should also be appropriated for micro-analysis. In other words, within each major zone the other zones exist to some extent as well. West Virginia is a prime example of this. On the large scale, the state had been incorporated into this system long before 1880. Before heavy industrialization, the state was a periphery in the capitalist world system. Scarcity of capital, terrain, and lack of transportation stunted progress. ${ }^{45}$ In fact, West Virginia itself housed various zones. The river valley regions mentioned above constituted at least a semi-periphery, if not a core, with the interior and the mountains being a periphery within a periphery. Likewise, there were other economic and social similarities between pre-industrial West Virginia and more advanced regions of the country. Subsistence farming and isolation were the exceptions, not the rule. Social classes existed as they did elsewhere, and in many cases to a greater extent. Even before the 1880s, absentee landowners, including men such as Davis who were officially residents of West Virginia but spent significant time elsewhere (Davis maintained a home in Deer Park, Maryland), played a major role in shaping the state's development. Below them, an ecosystem of local elites, small landholders, landless farmers, laborers, and others operated in much the same fashion as it did elsewhere in the country. ${ }^{46}$

This continuum suggests the need for careful delineation between quantitative differences and qualitative differences. Despite some quantitative differences between West Virginia and the rest of the country in terms of available capital, standard of living, technology, etc., important

\footnotetext{
${ }^{44}$ Dunaway, 8-10.

${ }^{45}$ Dunaway, 152-154.

${ }^{46}$ Dunaway, 125; Lewis, 51.
} 
qualitative similarities existed. West Virginians wanted to use the natural resources available to them to the fullest extent - to benefit economically and materially. However, as a whole, the population lacked the financial and technological means to maximize the potential around them. As historian Ronald L. Lewis points out, "these were the influences that shaped their economic relationship to the forest around them, not the lack of enterprise or a pre-capitalist mentality." ${ }^{\prime 4}$ Sacred-West Virginia

In addition to the similarities in the secular sphere, West Virginia was also similar to other Appalachian states in the sacred sphere. Antebellum religious developments in the region in general and the state in particular shaped the missionary efforts of the Gilded Age and Progressive Era. The two religious events of the pre-Civil War period which had the most influence on missionary and church growth efforts were the Second Great Awakening and the denominational splits. The Second Great Awakening started at Cane Ridge, Kentucky, in 1801 at a mass religious gathering featuring Presbyterians, Methodists, and Baptists. The latter two denominations quickly adopted the camp meetings to their advantage. By 1850, a little more than a decade after the revival fires died down, the two groups combined claimed nearly eightyfive percent of denominational adherents in Central Appalachia. Presbyterians constituted most of the remaining fifteen percent. These trends continued through the nineteenth century. ${ }^{48}$

As the revival fires died down, sectional conflict between North and South heated up. Denominational division presaged, and many argue helped provoke, national political division. ${ }^{49}$

\footnotetext{
${ }^{47}$ Lewis, 35 .

${ }^{48}$ Roger Finke and Rodney Stark, The Churching of America, 1776-2005: Winners and Losers in Our Religious Economy (New Brunswick: Rutgers, 2005), 156, 157, 291-293. See also Leigh Eric Schmidt, Holy Fairs: Scotland and the Making of American Revivalism (Princeton: Princeton University Press, 1989) and Nathan O. Hatch, The Democratization of American Christianity (New Haven: Yale, 1989).

${ }^{49}$ C.C. Goen, Broken Churches, Broken Nation: Denominational Schisms and the Coming of the Civil War (Macon: Mercer University Press, 1985), 13.
} 
Presbyterians were the first major Protestant denomination to split, although it was not primarily along geographical lines. In 1837, Old School Presbyterians, those who supported a traditional understanding of the Westminster Confession and Reformed theology, looked askance at the Second Great Awakening and opposed cooperation with more liberal denominations (namely Congregationalists) took control of the General Assembly and excommunicated four synods loyal to the New School. New School Presbyterians favored continued cooperation with the Congregationalists, sought fresh interpretations of the Westminster Confession, and supported the Second Great Awakening. Very quickly a New School General Assembly formed. By 1838 the rival assemblies boasted nearly identical membership numbers. ${ }^{50}$

While theology and polity issues were the primary reasons for this divide, slavery was not far beneath the surface. Presbyterians in the South, the majority of whom were Old School, grew increasingly fearful of abolitionist agitation in the North, which came mostly from New Schoolers. While the slavery issue would become the chief concern of the Southerners, in the late 1830s they were genuinely concerned with what they saw as the New School drift away from the Westminster Confession, especially among the abolitionists of the North. While some of the great defenders of Presbyterian orthodoxy such as Charles and A. A. Hodge hailed from the North, as a whole Southerners were more conservative and fiercely loyal to their confessional heritage. Old Schoolers in the North feared that if the Southerners left over slavery, New School thought would control the General Assembly and all checks against suspect doctrine and practice would disappear. ${ }^{51}$ Thus, a schism over theology and polity helped preserve geographical unity.

However, about twenty years later, division over slavery ensued, briefly resulting in four

\footnotetext{
${ }^{50}$ Goen, 68, 69 .

${ }^{51}$ Goen, 69; James H. Smylie, A Brief History of the Presbyterian Church (Louisville: Geneva Press, 1996), 78, 79.
} 
denominations. The New School split along geographical lines in 1858, with Southerners forming the United Synod of the Presbyterian Church in the United States of America. The Old School remained united until late 1861. With war a reality, the Southern Old Schoolers formed the Presbyterian Church in the Confederate States of America (PCCSA). The two Presbyterian groups in the South combined in 1864 under the PCCSA name. ${ }^{52}$

Most of the churches in what became West Virginia belonged to the Synod of Virginia, either New or Old School, and thus affiliated with the PCCSA. These were divided among three presbyteries - Greenbrier, Lexington, and Winchester. Winchester encompassed northern Virginia, counties in what became West Virginia's eastern panhandle, and parts of western Maryland. The Greenbrier and Lexington were especially large. The former extended from what would become the border between Virginia and West Virginia to the Kentucky border, cutting through the southern tier of what became West Virginia. The latter's territory included counties between the Valley of Virginia and the Appalachian Plateau in central western Virginia, extending almost to the Ohio River. ${ }^{53}$

Presbyterian churches in the Northern panhandle belonged to the Washington (PA) Presbytery. Before the Civil War, counties in the Northern tier of West Virginia extending from the Maryland border to Ohio River and down to Point Pleasant belonged to the Redstone Presbytery. Both the Redstone and Washington Presbyteries belonged to the Synod of Pittsburgh. During the Civil War, that synod moved West Virginia churches in the Redstone Presbytery to the newly created Presbytery of West Virginia. Thus, some West Virginia

\footnotetext{
${ }^{52}$ Goen, 88-91.

${ }^{53}$ Howard M. Wilson, The Lexington Presbytery Heritage (Verona, VA: McClure Printing Company, Inc., 1971), $102,129$.
} 
Presbyterians continued their alliance with the Northern Presbyterians. ${ }^{54}$

From its beginnings in the United States, the Methodist Episcopal Church wrestled with the issue of slavery. In 1828, a group broke off from the larger denomination over polity issues. The Methodist Protestant Church rejected the episcopal form of government and instead adopted a more democratic polity, with an elected president running the General Conference. The president made all pastoral appointments, but these were confirmed by a committee at the annual conference. Lay people were also granted representation at the General Conference. However, the reformers remained ambivalent about slavery. The Methodist Protestant Church let constituent annual conferences make choices about admitting black members and refused to make a definitive statement on slavery. An anti-slavery faction, tired of inaction, broke off in $1858 .^{55}$

Throughout the 1840s, the slavery issue continued to plague the Methodist Episcopal Church. An abolitionist group formed the Wesleyan Methodist Church in 1843. The next year, ME Church could no longer ignore the issue. Anti-slavery advocates remained a powerful force in the General Conference and in many annual conferences, even along the border states. They insisted that bishops not be allowed to own slaves. Thus, in their view, Bishop James O. Andrews from Georgia would either have to resign from the episcopacy or free his slaves. Andrews did not own slaves when he became a bishop, but had acquired them upon the death of his wife. He did offer to resign his position, but Southerners would not let him. This became a test case. Both sides recognized that the core of the matter was the moral issue of slavery.

\footnotetext{
${ }^{54}$ Wilson, 415; William Wilson McKinney, The Presbyterian Valley (Pittsburgh: Davis \& Ward, Inc., 1958), $196-199$. Immediately after the Civil War, the Northern Presbyterian church attempted to claim all Presbyterian churches in West Virginia that had been part of the Presbytery of Lexington. These churches showed no interest in being part of the Northern branch and were dropped from Northern roles in 1869. See Wilson, 415, 416.

${ }^{55}$ Russell E. Richey, Kenneth E. Rowe, and Jean Miller Schmidt, The Methodist Experience in America: A History, vol. 1 (Nashville: Abingdon Press, 2010), 171, 194.
} 
However, the debate revolved around various procedural questions. In the end, a vote of 110 to 68 , largely along sectional lines, called for Andrews to give up his office or his slaves. ${ }^{56}$

Over the course of the debate over Bishop Andrews, which took more than a week, both sides came to believe separation was inevitable. Every effort was made at reconciliation, and neither side took the decision to divide the conference lightly, but the Andrews case made it clear that compromise was just not possible. However, as Methodist historian Robert Sledge points out, despite the differences between the two sides and the anguish with which Methodism faced divisions, both sides called the action a mutual parting, not a schism. ${ }^{57}$

During the 1844 General Conference Methodists formed a committee for the expressed purpose of laying the groundwork for separation, should the South choose to leave. Beyond the legal issues, including ownership of church property, one of the key goals of the committee was to establish a fair process by which border churches could make a decision to remain or to leave. In short, the Plan of Separation allowed for churches along the border to vote, yet problems quickly arose when implementing the plan. A basic problem from the beginning was the fact that conference boundaries crossed state lines. Some northern conferences contained pro-slavery churches, and vice versa. Dividing Methodism between North and South was not as easy as simply drawing a line on a map.

In 1845, the Southern churches formed the Methodist Episcopal Church, South. They quickly established all the committees and boards necessary for the continuation of Methodist work in the South. Next, they moved to consolidate their position in the border conferences. The Methodist Episcopal Church did the same. Virginia, Maryland, Kentucky, Delaware, the

\footnotetext{
${ }^{56}$ Frederick A. Norwood, The Story of American Methodism (Nashville: Abingdon Press, 1974), 198.

${ }^{57}$ Robert W. Sledge, Five Dollars and Myself: The History of Mission of the Methodist Episcopal Church, South, 1845-1939 (New York: General Board of Global Ministries, 2005), 34, 35.
} 
District of Columbia, and Missouri became sites of intense conflict. Fraternal relations quickly soured. By 1848, the MEC repudiated the Plan of Separation and argued that the church had never legally divided. ${ }^{58}$

The distrust between the two sides had profound implications for the counties that would become West Virginia. Both sides claimed the territory west of the mountains. The MEC formed a Western Virginia Conference out of those parts of the Pittsburgh Conference that were located in Virginia. This became the West Virginia Conference after the war. Southern Methodists believed that because these counties were clearly in the South, they should be included in the Southern General Conference. Thus, the MEC, South formed its own Western Virginia Conference, which retained the name even after West Virginia statehood. ${ }^{59}$ Neither of these conferences, however, included all fifty-five counties that would become West Virginia. Even after the war, the Baltimore and Virginia Conferences would claim some of the counties in the state, namely those in the eastern panhandle and a few along the Virginia border.

The situation between these two conferences was much more complex. The Baltimore Conference remained loyal to the MEC. It extended south through the Blue Ridge and thus included many churches in Virginia. The Virginia Conference drew some of these away, but most stayed in the MEC until after the war, when they united with the Southern church. Some Maryland and D.C. churches also left the Baltimore Conference after the war. In 1866, these Virginia and Maryland congregations formed a Baltimore Conference in the MEC, South. ${ }^{60}$

\footnotetext{
${ }^{58}$ Richey, et. al., 192, 193.

${ }^{59}$ Richey, et. al., 193.

${ }^{60}$ Edwin Schell, "The Baltimore Conference, Methodist Episcopal Church, South," in Those Incredible Methodists: A History of the Baltimore Conference of the United Methodist Church, ed. George Pratt Baker, (Baltimore: Commission on Archives and Records, Baltimore Conference, 1972), 258; Schell, "The Virginia Conference of the Methodist Episcopal Church, 1867-1906," in Those Incredible Methodists, 274, 275.
} 
The MEC likewise made incursions into Southern territory. Some congregations in Northern Virginia continued to express political and religious loyalty to the North. The MEC also made conscious efforts to regain churches in the upper South, especially in Virginia. During the war the federal government had allowed MEC bishops to administer churches in occupied areas. The MEC also created a specific home mission division for the South. Finally, in 1868, it created a Virginia Conference of its own. ${ }^{61}$

Baptists divided for similar reasons and in similar ways in 1845. Baptist denominational organization in the antebellum period was not nearly as extensive as that of Methodists or Presbyterians. Baptists first organized for the purpose of foreign missions. In 1814 they formed the General Missionary Convention of the Baptist Denomination in the United States for Foreign Missions. The body met every three years and became known as the Triennial Convention. True to Baptist polity, the group had no judicial or legislative authority over constituent churches. It was based on existing state Baptist societies dedicated to the task of foreign missions. The Triennial Convention raised funds and organized and supported missionary endeavors overseas. During the early nineteenth century, a home mission and a tract society also formed. Like the Triennial Convention, these had no authority over local churches. ${ }^{62}$

Like the Methodists, the Baptists tried to remain neutral on slavery. In 1841, the Triennial Convention adopted an official policy of neutrality. However, extremists on both sides continued to press the issue. At issue was whether missionaries, foreign and domestic, could own slaves. The Home Mission Society passed a neutrality resolution in 1844, but also approved a motion to consider dissolving the group. At that same meeting, in an admittedly provocative

\footnotetext{
${ }^{61}$ Schell, "The Virginia Conference...," 276.

${ }^{62}$ H. Leon McBeth, The Baptist Heritage: Four Centuries of Baptist Witness (Nashville: Broadman Press, 1987), 344-368.
} 
move, Georgia Baptists nominated a slave owner to be appointed as a missionary. The society did not act, believing a decision either way would violate the neutrality stance. ${ }^{63}$

That same year, Alabama Baptists sent a letter to the Triennial Convention asking whether a slave holder could become a foreign missionary. They also believed that state and local bodies should share appointment power with the board. In response, the Board was quite clear that it and it alone had the power to appoint missionaries. On the slavery issue, the Board attempted to re-affirm neutrality, but clearly stated it would do nothing to support slavery. To Southerners, this seemed to violate neutrality, and both sides knew division was inevitable. ${ }^{64}$

Virginia, Georgia, and South Carolina led the way in forming the Southern Baptist Convention in 1845. Like the Southern Methodists, Southern Baptists quickly erected the denominational infrastructure necessary for continued mission work. They united domestic and foreign mission work, creating a board for each endeavor under the control of the Convention. In doing so, they adopted a different system of denominational organization. The convention emphasized greater denominational centralization, control, and organization. Essentially, the SBC was a body in which a number of churches united for a variety of causes. ${ }^{65}$

By contrast, the North retained the society model. While the Triennial Convention and Home Mission Society oscillated between society and convention models throughout the antebellum period, they always exhibited some essential characteristics of the society model of organization. Chief among these was the single cause to which each was devoted. Whereas the SBC handled many different issues, the Home Mission Society and the Triennial Convention, or

\footnotetext{
${ }^{63}$ McBeth, 386, 387.

${ }^{64}$ McBeth, 388, 389.

${ }^{65}$ McBeth, 348, 388-391.
} 
the American Baptist Missionary Union, as it was called after schism, each dealt exclusively with one area. Furthermore, membership in a society was limited to individuals, not churches. This was the original intent of the Triennial Convention, but the wording of its constitution left open the possibility of elected delegates representing churches. After the schism, the ABMU specifically changed its constitution to state that only individuals were members, and represented only themselves, not churches or state and local associations or mission societies. Baptist scholar Leon McBeth notes that while this move was intended to protect the autonomy of the local church, it technically removed mission work from the local church and placed it in a nonchurch body. The Home Mission Society had the same structure, but the strength and number of local and state mission societies meant that local churches continued to hold significant control over domestic missions into the twentieth century, and made crafting a national, or at least regional, home mission strategy difficult in the post-Civil War era. ${ }^{66}$

The loose structure of the Triennial Convention and the Home Mission Society meant that schism among Baptists was not quantitatively the same as the divisions in the other two major Protestant bodies. Baptists did not have that much to split. Missionary efforts were really the only part of church life affected by the split. In fact, for a number of years both Northern and Southern Baptists supported the work of the American Baptist Publication Society. However, the Baptist schism was the qualitative equal to Methodist and Presbyterian splits precisely because Baptists organized at the national level almost exclusively for the purpose of missions, both foreign and domestic.

The story of Virginia Baptists reveals the similarities and differences between the Baptist schism and the other denominational splits. This situation demonstrates the loose national

\footnotetext{
${ }^{66}$ McBeth, 348, 393, 410.
} 
structure of Baptist organization and the importance of local church autonomy and associationalism. It also had a direct impact on Baptists in West Virginia. In 1823, the various local associations of Virginia formed the General Association of Baptists in Virginia. This was the first state-wide Baptist organization in Virginia. Many of the founders wanted greater cooperation for missions. Yet many others were suspicious of foreign missions and weary of greater centralization, regardless of the cause. Thus, the group's constitution specifically forbade it from uniting with the Triennial Convention, at that time the only national Baptist group. ${ }^{67}$

Not to be deterred, pro-mission forces organized another state group in 1826. The Baptist Foreign and Domestic Mission Society of Virginia became the Baptist Mission Society of Virginia, and affiliated with the Triennial Convention. Now Virginia had two state-wide denominational structures, and there was some competition for funding. This was one factor leading to the General Association's decision in in 1835 to correspond with, but not fully join, the American Baptist Home Mission Society, which organized in $1832 .{ }^{68}$

The General Association was the larger of the two Virginia Baptist bodies. It was the creation of the various local associations, so all of the churches in those associations were members of the state group, even if they chose, for whatever reason, not to participate in or donate to it. The Baptist Mission Society, by contrast, was comprised only of those interested in foreign missions, and not necessarily entire churches. Furthermore, the primary focus on the Baptist Mission Society was cooperation with the Triennial Convention. Thus, the General Association undertook most of the missionary activities in Virginia, including the western portion beyond the mountains, and the churches in that section of the state almost exclusively

\footnotetext{
${ }^{67}$ Reuben E. Alley, A History of Baptists in Virginia (Richmond: Virginia Baptist Publishing Board, 1969), 169-175. ${ }^{68}$ Alley, 175, 176, 192.
} 
affiliated with the General Association, and not the Baptist Mission Society.

When the Triennial Convention split, the Virginia Baptists leading the way belonged to the Baptist Mission Society, not the General Association of Baptists in Virginia.

In 1844, upon the recommendation of the General Association, six associations in western Virginia formed an auxiliary body called the Western Virginia Association. It took on much of the burden for evangelizing that portion of the state. In 1850, this group formed the Northwestern Virginia Association, and then disbanded. The new body performed the same tasks as the old, yet did not include the same associations. The Greenbrier and Teays Valley Associations, which included the southern tier of what is now West Virginia, extending from the Blue Ridge to the Kentucky border, had belonged to the WVA but did not join the body that replaced it. The NVA continued to serve the transmontane until 1859, when it disbanded. Its mission board lingered on until 1861 when, out of funds, it ceased to exist as well. ${ }^{69}$

Thus, initially, the Baptist churches in what is now West Virginia were affiliated with neither the Triennial Convention nor the Southern Baptist Convention. Throughout the 1840s, the General Association's popularity grew, as did that of the various Baptist societies in the state. In 1845, the General Association first considered uniting these different groups, which included a Bible Society, a Sunday School and Publication Society, and the Mission Society affiliated with the SBC. No action was taken, however, until 1854, when a new constitution was written, restructuring the entire entity. With the Mission Society now under its control as the State Mission Board, the General Association was now a member of the Southern Baptist Convention. ${ }^{70}$ Technically, the churches in western Virginia were then also members of the SBC.

\footnotetext{
${ }^{69}$ Arthur Hank, A.B. Withers, and John S. Stump, eds., Baptist General Association of West Virginia: Jubilee Volume (s.l.: s.n., 1915), 39-42.

${ }^{70}$ Alley, 227, 228.
} 
However, local association minutes from the period make no references to the SBC. In 1865 , the churches in the new state of West Virginia organized the Baptist General Association of West Virginia. They received some help from the American Baptist Home Missionary Society. They maintained correspondence with the ABHMS, but did not fully unite with them. They also expressed willingness to correspond with the SBC and encouraged local churches to seek financial help from whichever national group they saw fit. ${ }^{71}$

Many of the churches did just that, at least for a few years. Churches in the north and northwest reached out to the Northern Baptists. Congregations in the south turned to the Southern Baptists. In fact, the Greenbrier, Teays Valley, and Guyandotte Associations, all three in southern West Virginia, did not join the West Virginia General Association in 1865. Greenbrier and Guyandotte did not even send representatives, and Teays Valley only sent observers. All three maintained ties to the Virginia Baptists and the SBC until 1868, when they broke from the Virginia Baptists and joined with the rest of West Virginia Baptists. A few individual congregations, especially in the border counties, remained involved with Virginia and Southern Baptist life, but in the immediate post-war years and throughout Reconstruction, West Virginia Baptists as a whole were independent, officially unaffiliated with either national group. $^{72}$

Patterns of church affiliation established before the war persisted with remarkable continuity through Reconstruction. Methodists, divided between two General Conferences and five constituent annual conferences, constituted the largest religious group in the new state of West Virginia. By 1875, the West Virginia Conference of the Methodist Episcopal Church

\footnotetext{
${ }^{71}$ Hank, 46.

${ }^{72}$ Rogers, 4-9.
} 
counted 25,116 members. Most of its strength lay in the northern and central counties. The Western Virginia Conference of the Methodist Episcopal Church, South, registered 14,187 members in 1878. Most of those congregations were located in the south and west. ${ }^{73}$

Baptists, who sided overwhelmingly with their Northern co-religionists, fell to a firm but distant second in the new state. In 1868, the Baptist General Association reported 16,347 members. ${ }^{74}$ By 1883, the next time the General Association issued a report, membership had jumped by nearly ten thousand, bringing the total number of Baptists affiliated with the BGA to 26,335. ${ }^{75}$ Baptist churches in all parts of the state fellowshipped through the General Association.

The Southern Baptist Convention had such a small presence in West Virginia after the Civil War that exact membership numbers are hard to find. The SBC attempted to maintain some links with churches in West Virginia, mostly in the southern part of the state. However, Convention records report no numbers. United States Census records give some indication as to the paucity of Southern Baptists in West Virginia. According to the 1906 Census of Religious Bodies, the first such survey conducted by the federal government, there were just 1,672

\footnotetext{
73"'Statistical Report," Official Journal of the West Virginia Conference of the Methodist Episcopal Church, 1875, n.p.; "Statistical Report," Western Virginia Conference Journal, Methodist Episcopal Church, South, 1878, n.p.; Carl E. Burrows, Robert D. Florian, David F. Mahoney, Melting Times: A History of West Virginia United Methodism, 1784-1989 (Charleston, WV: Commission on Archives and History, West Virginia Conference, United Methodist Church, 1984), 108, 109, 185. Technically, these numbers are not indicative of the complete number of Methodists in West Virginia. Neither the West Virginia Conference nor the Western Virginia Conference included the entire state. Between the two branches there were three other conferences that included some West Virginia counties. Thus, the totals given here are actually somewhat lower than the total number of Methodists in the entire state. Nevertheless, the reports from the West Virginia Conference and the Western Virginia Conference are sufficient to show the overwhelming numerical superiority of Methodists in West Virginia at the time. The Methodist Protestant Church, the smallest of the three branches of Methodism in West Virginia, claimed 7,222 members. The northern and central counties claimed most of these churches. See "Church Statistics," Procedures of the Twenty-Fourth Session of the West Virginia Annual Conference of the Methodist Protestant Church (Parkersburg, WV: George Elletson Publisher, 1877), 23.

74“"Statistical Table," Minutes of the Baptist General Association (Parkersburg, WV: Sentinel Publishing, 1868), n.p.

75،"Statistical Table,” Minutes of the Baptist General Association (Parkersburg, WV: Sentinel Publishing, 1883), n.p.
} 
Southern Baptists in the state. ${ }^{76}$

Primitive Baptists also constituted a small minority of Baptists in West Virginia. Because records from the several Primitive associations in the state are almost non-existent, the federal Census of Religious Bodies again provides the best glimpse at the numerical situation of those churches. While small, Primitive Baptists still outnumbered Southern Baptists, with 2,019 reported members. ${ }^{77}$ Thus, an exact count of all Baptists in West Virginia is hard to make. However, based on the small number of Southern and Primitive Baptists in 1906, and the roughly 16,000 Baptists affiliated with the BGA in 1868 and their subsequent 10,000 member increase by 1883, it seems reasonable to put the total number of Baptists in West Virginia in the 1870s at approximately 20,000 to 25,000 . Regardless of the exact total, it is clear that mainline Baptists made up the majority of Baptists in the state after the Civil War.

Presbyterians, both North and South, combined to rank third among Protestant groups in West Virginia. The Northern branch of the church, the Presbyterian Church of the United States of America, was confined almost exclusively to the northern tier of the state, including the northern panhandle, as well as a few counties in the northwest corner of the state along the Ohio River. They claimed just 1,697 members in $1875 .^{78}$ Their southern counterparts, the Presbyterian Church in the United States, had 8,734 members that same year. ${ }^{79}$ The southern branch dominated the central, southern, and eastern parts of the state.

Sacred-Alleghenies

\footnotetext{
${ }^{76}$ Religious Bodies: 1926, vol. 2. (Washington: United States Government Printing Press, 1929), 196.

${ }^{77}$ Religious Bodies, 85.

78“"Statistical Report," Minutes of the General Assembly of the Presbyterian Church of the United State of America (Philadelphia: Presbyterian Board of Publication, 1875), 870, 871.

79،"Statistical Reports," Minutes of the General Assembly of the Presbyterian Church in the United States (Richmond: Presbyterian Committee on Publication, 1875), 168, 169, 173, 174, 196, 197.
} 
The ubiquity of Methodists in the state was mirrored by their numerical dominance in the mountain counties. However, although state-wide Baptists notched a respectable second statewide, with Presbyterians trailing in third, in the mountains that situation was reversed. In the highest elevations, Baptists were nearly non-existent. Presbyterians had a solid presence behind Methodists, but only two Baptist churches existed in the five counties studied here.

Although circuit riders brought Methodism to this part of the state around the turn of the nineteenth century, permanent congregations were not established until the late antebellum period, many of them after the schism. Nevertheless, by 1880 Methodism was well-entrenched in the region. Generally speaking, both major branches were well-represented in each county. In addition to this division, the churches in these five counties represented the five conferences that partitioned West Virginia. Three of these - the West Virginia Conference, the Baltimore Conference, and the Virginia Conference - were affiliated with the MEC. The MEC, South also had a Baltimore Conference, in addition to its Western Virginia Conference.

By the time industrialization began in earnest throughout the region, the MEC claimed a total of thirteen congregations in four charges along the tracks of the West Virginia Central and Pittsburg. Tucker County had one circuit with five congregations; Randolph had one circuit with two congregations. Both Pocahontas and Mineral had one circuit with two congregations and one station church each. ${ }^{80}$

The numbers for the MEC, South are very similar. It had four circuits that included twenty-one churches. The Tucker circuit was the largest, with seven congregations. Randolph

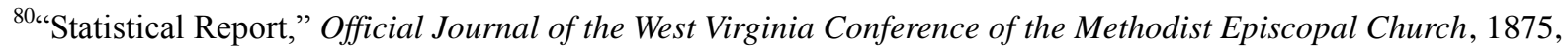
n.p.; "Statistical Report," Annual Minutes of the Virginia Conference of the Methodist Episcopal Church (Baltimore: Methodist Episcopal Book Rooms, 1874), n.p.; "Statistical Report," Minutes of the Baltimore Annual Conference of the Methodist Episcopal Church (Baltimore: William K. Boyle and Son, 1875), 86, 87. Grant County also had a station church belonging to the Baltimore Conference at this time. However, the church was in Petersburg, which was not close to the WVC\&P.
} 
had one mission church. Pocahontas County had two circuits with five and two congregations respectively. In addition to two station churches, there was one circuit in Mineral County with four congregations. ${ }^{81}$

Numerically, Presbyterians came in second behind Methodists in the mountains. The three largest groups of Methodists had churches in these counties, but the highlands were home to only one wing of Presbyterianism - the Presbyterian Church in the United States. Ironically, a church closely connected with the Confederacy and slavery constituted the second-largest denomination in a part of the state with high levels of Union sympathy during the Civil War. Overall, by 1880 there were eleven Presbyterian churches across the five counties studied here. They were divided among three presbyteries. The Winchester Presbytery claimed four churches, three in Mineral County and one in Grant. The Lexington Presbytery included four churches, three in Randolph and one in Tucker. The three churches in Pocahontas County were in the Greenbrier Presbytery. ${ }^{82}$

For whatever reason, Baptists did not fare well in the Allegheny highlands before 1880 . It was as if the mountains deflected them to the east and to the west. In the five counties examined here, which included the two of the three geographically largest in the state (Randolph and Pocahontas), there were just two Baptist churches before 1880. These two small groups constituted the Old Time Baptist presence in the mountain counties. In 1880, they comprised the

\footnotetext{
81“'Statistical Report,” Western Virginia Conference Journal, Methodist Episcopal Church, South, 1878, n.p.; "Statistical Report," Minutes of the Baltimore Annual Conference of the Methodist Episcopal Church, South (Baltimore: King Brothers, 1876), 74, 75. The Methodist Protestant Church also had a presence in the mountains, albeit a significantly smaller one. The areas served by the WVC\&P contained five churches - one in Tucker, one in Randolph, and three in Pocahontas. See Church Statistics," Procedures of the Twenty-Fourth Session of the West Virginia Annual Conference of the Methodist Protestant Church (Parkersburg, WV: George Elletson Publisher, 1877), 23. The term "station church" signifies a single congregation not belonging to a charge. Station churches were usually located in larger towns and cities.

82،"Statistical Reports," Minutes of the General Assembly of the Presbyterian Church in the United States (Richmond: Presbyterian Committee on Publication, 1875), 168, 169, 173, 174, 196, 197.
} 
only examples of the "mountain church tradition" in that part of the state. Both of them were within a few miles of each other in the Tygart Valley, which ran through Randolph County. Originally, the two congregations had been one, known as the Valley Baptist Church, located near Beverly, the county seat. Founded around the turn of the eighteenth century, the Valley Baptist Church joined the Union Association in $1806 .{ }^{83}$ In 1825, the congregation sent a letter to the Union Association, which included churches in several counties in north central West Virginia, concerning benevolent societies such as tract and mission societies. The local church doubted the legitimacy of these so-called "man-made" agencies and wanted to know the association's position. The association responded that Sunday schools and benevolent societies were "agreeable to the will of God, and the will of this association" ${ }^{84}$ Not satisfied with this answer, Valley Baptist Church remained anti-mission and refused to attend association meetings. In response to this, the association dropped the church from its rolls in 1826 without protest from the Valley church. ${ }^{85}$

The Union Association lost two other churches to the anti-mission cause, but remained otherwise intact and healthy. In 1854, a second Primitive Baptist church formed in Randolph County. A group from the Valley church traveled down the valley to Leading Creek, a small community in the northern part of the county, to start a new church. The splitting, or "arming off," as it was often called, was amicable. These two churches, along with two Primitive Baptist churches from neighboring Barbour County to the west, formed their own association. ${ }^{86}$ No

\footnotetext{
${ }^{83}$ Truett Rogers, West Virginia Baptist History: The Early Years, 1770-1865 (Terra Alta, WV: Headline Books, 1990), $44,52$.

84“"Queries," Minutes of the Union Baptist Association, 1826, 4.

${ }^{85}$ “Business," Minutes of the Union Baptist Association, 1826, 4.

${ }^{86}$ Daisy Ferguson Martin, Montrose Community History (Elkins, WV: Published for the Montrose Historical Society, 1991), 14. Records for this area and time are very scarce. There may have been another Baptist church in Randolph
} 
membership records exist for the churches during the 1870s. However, according to local

historian Hu Maxwell, by the 1890s each church had fewer than 50 members - twenty-three

worshiped at the original church while forty-five belonged to the Leading Creek Congregation. ${ }^{87}$

While these low numbers could be related to missionary Baptist incursions, state-wide records

suggest generally low numbers of Primitive Baptists in the area prior to wide-spread

industrialization. In any case, Baptists lacked the institutional foundation of the Methodists and

Presbyterians. As missionaries from the various denominations flocked to the mountains during

the Gilded Age, Baptists started with a distinct disadvantage.

At the dawn of the industrial era in West Virginia, the religious situation in the mountains

was, for the most part, both mainline and theologically polarized. By virtue of denominational

polity, both Methodist and Presbyterian congregations maintained close connections with state

and national denominational structures. Holiness teachings had emerged before the Civil War,

principally in the North, and became institutionalized in the National Camp Meeting Movement

after the war. This revitalization of holiness concepts enjoyed episcopal support, helping delay

the emergence of distinct holiness denominations until the 1880 s, some of which soon became

Pentecostal churches. ${ }^{88}$ Even then, most of earliest denominations did not originate in

County that went anti-mission in the 1820s. Robert Baylor Semple, in A History of the Rise and Progress of the Baptists in Virginia (Richmond: Pitt and Dickinson, 1894), notes that a Little Bethel Baptist Church was founded in Randolph County in 1796 and was a charter member of the Union Association. The association minutes mention such a church, but give no location for it. The minutes also indicate that a Little Bethel Church did leave the Union Association with the Valley church. Other records indicate that two other Little Bethel churches existed in counties covered by the Union Association, one of which was Barbour County. Since Martin's community history of Montrose states that the Primitive Baptist Churches in Randolph fellowshipped with Primitives in Barbour, the Little Bethel which left the Union Association in 1826 may very well have been in Barbour County, and not in Randolph. If the church was in Randolph, it likely closed or merged with the Valley Church, since no other mention is made of a Little Bethel Church in Randolph County after the 1820s.

${ }^{87}$ Maxwell, A History of Randolph County, West Virginia, 313.

${ }^{88}$ Russell E. Richey, Kenneth E. Rowe, and Jean Miller Schmidt, The Methodist Experience in America: A History, vol. 1 (Nashville: Abingdon Press, 2010), 330, 331. See also Vinson Synan, The Holiness-Pentecostal Tradition (Grand Rapids: Eerdmans, 1977), Robert Mapes Anderson, Vision of the Disinherited: The Making of American 
Appalachia, but in the North, Midwest, and West. The lone exception was the Church of God, a Pentecostal denomination with holiness origins dating to 1886 in the mountains of eastern Tennessee and western North Carolina. That group initially spread to the Midwest and lowland South, not primarily back through Appalachia.

Holiness churches and denominations did not take root in Appalachia in general, and West Virginia in particular, until around 1900, and it would be nearly another decade before holiness and Pentecostalism came to the Allegheny region of the state. ${ }^{89}$ Along with Old Time Baptists and other independent churches, the holiness and Pentecostal groups supposedly constitute the core of Appalachian religious identity. This "mountain church tradition" represented a strand of highland Christianity distinct and separate from that of the rest of America. However, an overview of the religious demographics in the post-Civil War Allegheny region of West Virginia suggests a different sacred reality. In the two decades immediately following the Civil War, those churches believed to be central to mountain religion had almost no presence in the highest mountains of West Virginia. Rather, mainline Protestants - Methodists and Presbyterians in particular - controlled the religious development of that part of the state.

Theologically, an interesting mix of traditional Calvinism and Wesleyanism prevailed. Through the 1870s, the Southern Presbyterian Church remained wedded to its traditional Calvinist moorings. Although there were three branches of Methodism competing in this region, they all three agreed on the basics of Wesleyan theology. The Methodist emphasis on personal and social holiness and free grace for all stood in stark contrast to the predestinarian theology of

Protestantism (New York: Oxford, 1979), and Charles Edwin Jones, Perfectionist Persuasion: The Holiness Movement and American Methodism, 1867-1936 (Metuchen, NJ: The Scarecrow Press, Inc., 1974).

${ }^{89}$ Donald H. Bowdle, "Holiness in the Highlands: A Profile of the Church of God," in Christianity in Appalachia, Bill Leonard, ed. (Knoxville: The University of Tennessee Press, 1999), 245-252; Melvin E. Dieter, "Wesleyan/Holiness Churches," in Christianity in Appalachia, Bill Leonard, ed. (Knoxville: The University of Tennessee Press, 1999), 232, 233; Deborah Vansau McCauley, Appalachian Mountain Religion (Chicago: University of Illinois Press, 1995), 255-310. 
the Presbyterians. The greatest difference among the major branches of Methodism was not over theology, it was over polity; it was not between the MEC and the MECS but between those two branches and the Methodist Protestant Church. This latter group remained committed to the rest of Wesleyan theology while rejecting the episcopacy. While there may have been pockets of holiness teaching in local Methodist congregations, immediately prior to industrialization, Methodists in the Allegheny region remained loyal to the mainline General Conferences and faithful to mainline Wesleyan theology.

The prevalence of mainline denominations suggests the need for a different interpretive paradigm. The "mountain church tradition" paradigm is predicated on the presence of regional sub-denominations and independent churches. This dominant interpretive scheme centers around the strong sense of independence among local congregations, the shared theological views of different denominations, and an intense personal piety which emphasizes lived religious experience over erudite articulation of doctrine. Yet this brief overview of religion in the West Virginia highlands reveals a close connection between Protestant churches there and their coreligionists in the rest of America. Methodists and Presbyterians in this part of the state fellowshipped regularly with their respective national denominations. The one Baptist church, a Primitive congregation, did not represent the majority of Baptists in the state. When Baptist missionaries began to form new congregations, those bodies associated with the mainline Baptists and their theology and praxis resembled traditional Baptist orthodoxy, not the emerging liberalism.

\section{Conclusion}

The new paradigm applied here is popular religion. Baptist, Methodist, and Presbyterian development and growth are examined in three following chapters. The concept of popular 
religion is used as an analytical framework to understand these denominations in the Allegheny region of West Virginia and their relationships to the rest of mainline American Protestantism. The background given here provides a foundation for this approach. While the "mountain church tradition" is predicated upon difference, popular religion is based upon similarity. To be sure, there were key religious differences among Protestants in West Virginia and those in the rest of America, and many of those were strengthened during the period covered by this study. However, the similarities not only outnumbered the differences, but they also reflected the central religious identities of Protestants to a much greater degree than did the points of difference.

The situation in the secular sphere corresponds to sacred realities. Prior to the $1880 \mathrm{~s}$, West Virginia was not completely isolated from the rest of America. While the state was overwhelmingly agrarian and under-industrialized, existing trade routes and modes of transportation allowed farmers and businessmen to get their produce and products to market. For landowners, natural resource extraction always remained an option. In the Allegheny region in particular, timbering occurred with some regularity as a quick way to raise revenue. Heavy industrialization would bring extensive changes to the state and region. However, the initial change - the gradual shift from agriculture to heavy industry - was not as foreign to the state as many seem to believe. Capitalists and industrialists introduced technological innovations that facilitated greater use of natural resources and that sparked an increase and expansion of many existing industries. As historian Kenneth Noe observes, "Modernization did not strike a primitive culture in the 1880 s, then; it began much earlier." ${ }^{\prime 90}$ The next chapter deals with these changes, which were more quantitative than qualitative. Focusing on industrialization in five

\footnotetext{
${ }^{90}$ Kenneth Noe, Southwest Virginia Railroad: Modernization and the Sectional Crisis (Chicago: University of Illinois Press, 1994), 6.
} 
mountain counties, it shows how an industrial economy replaced an agrarian one and how existing power structures either adapted to new forces and ways of life or were marginalized by efforts to resist. A later chapter deals with other, more far-reaching cultural and societal changes produced by new economic and political structures. These were as much if not more qualitative than quantitative. Ultimately, the re-shaping of mountain life resulted from a complex interplay between a particular set of pre-industrial values and attitudes and the dominance of more secularized and centralized nodes of authority that locomotives pulled into West Virginia as they rumbled through the state. 


\section{3: Industry in the Mountains}

\section{Introduction}

"The Alleghenies were as rich in coal and lumber as the Rockies were in the precious metals. The heart of the wealth of the Alleghenies is in West Virginia, and its throbbing has just

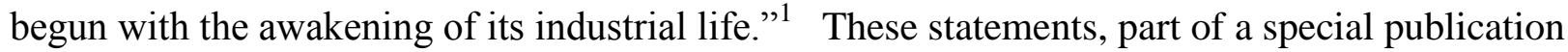
by the Board of Directors of the West Virginia Central and Pittsburg Railway, aimed to draw attention to the railroad's role in that industrial awakening and the profits which would follow. The WVC\&P, founded by a group of capitalists, politicians, and industrialists headed by Henry Gassaway Davis of Maryland, was one of the first railroads to penetrate the state's interior and the first to traverse its highest altitudes. The promotional publication covered the line's route into the mountains and detailed the natural resources along the way.

Henry Gassaway Davis embodied the development faith, the belief that natural resource exploitation would undergird more diversified economic development and propel the state to the forefront of an industrial America. He led the way in pioneering industrialization in the Allegheny mountains. As the passage above indicates, he believed the mountains held the key to the prosperity of the entire state, and by being a producer of the resources that drove American industry in the Gilded Age and Progressive Era, West Virginia could become an economic and political powerhouse in the nation.

Davis and his son-in-law Stephen B. Elkins concerned themselves primarily with coal, although they were more than willing to profit from other endeavors when given the opportunity. Their railroad also paved the way for those chiefly interested in timber. In addition to coal mines and coke furnaces, saw mills and feeder tracks appeared all over the mountains. Mining crews

${ }^{1}$ Sam Griffin, West Virginia Central and Pittsburg Railway Company (Indianapolis: The Independent Job Room, 1899), 8. 
took coal from beneath the earth as logging teams cleared the surface of enormous quantities of virgin timber. Natural resource extraction changed the landscape in more ways than one. In addition to the environmental impact, it also created a new set of economic and cultural realities. The comparatively small and localized economies of the mountains would be united into one vast web of trade and linked to national commerce by the steel rail. Regional and local elites such as Davis and Elkins, vied for control of this mountain bonanza, while others sought to profit where and when they could, hoping come out on top.

Into the Mountains: The Rise of the West Virginia Central and Pittsburg

With a background in the railroad industry and with a solid base in Mineral County, Henry Gassaway Davis stood poised to benefit from the vast wealth of the Alleghenies. In 1881, fifteen years after he secured an initial charter for his railroad in West Virginia, he secured an amended charter for a railroad to extend south into the mountains and also north into Pennsylvania, in order to eventually connect with another line that would lead to Pittsburgh. The West Virginia Central and Pittsburg Railway was born. While that line would never go to all the places for which its charter allowed, it almost single-handedly opened the Allegheny highlands region of West Virginia to the rest of the country, and vice versa.

The persons chosen as officers and board of directors for the new railroad demonstrate the close connection between political and economic clout during the period. The WVC\&P leadership also highlights how the quest for progress helped create a common American culture in the late nineteenth century that crossed geographical and political lines. Davis and Stephen B. Elkins served as president and vice-president respectively. The Board of Directors included several businessmen and politicians of regional and national repute: Johnson Newlon Camden of West Virginia; U.S. Secretary of State James G. Blaine; Augustus Schell, a Tammany man from 
New York City who served as Chairman of the Democratic National Committee in the 1870s; and William Keyser, the Vice-President of the Baltimore and Ohio Railroad. Several other national politicians held stock in the company, including the Secretary of the Treasury William Windom, Senator Thomas Bayard of Delaware (who would later serve as Secretary of State under Grover Cleveland), and Senator Arthur P. Gorman of Maryland. ${ }^{2}$

Construction began in 1881, and by September of that year trains hauled coal from Davis's mines in Elk Garden to Piedmont (both in Mineral County). ${ }^{3}$ Although its charter authorized the railroad to extend both north and south from its point of origin in Mineral County, West Virginia, the southern route took priority. Davis and his associates made frequent trips south over the mountains scouting possible routes. By meeting the B\&O near Piedmont, West Virginia, the WCV\&P already possessed an outlet to Eastern and Midwestern markets. The route to Pittsburgh could wait. The priority must be to harvest the vast supplies of coal and timber.

The Davis enterprise started well, although success was measured in more ways than miles of track laid. By late 1884, the road extended nearly 58 miles. It went south from West Virginia Junction, near Piedmont and the Maryland border, through southwestern Mineral County and the northeastern corner of Grant County past the Fairfax Stone into northwestern Tucker County. Two new towns were established - Davis and Thomas - to accommodate the flood of new workers in coal mines, lumber camps, saw mills, and tanneries. ${ }^{4}$

Industrialization turned both into boom towns well into the twentieth century. Along with a few select towns in Grant and Mineral counties, the fortunes of Davis and Thomas display the 2،"Extending a Virginia Line,” Baltimore America (Baltimore, MD), June 26, 1881.

${ }^{3}$ Henry Gassaway Davis, “Journal,” September 20, 1881.

${ }^{4}$ Third Annual Report of the President and Directors of the West Virginia Central and Pittsburg Railway Company to the Stockholders (Baltimore: W.J.C. Dulany and Co., 1885), 3. All future references to this or any other report from this company will be listed as Annual Report of the WVC\&P. 
blessing, or perhaps curse, of the railroad. As the oldest town on the line and site of Davis's earliest operations, Keyser consistently maintained a population of more than 2000 into the early years of the twentieth century. However, newer towns on down the line enjoyed much more rapid growth, even if their population levels remained about equal to that of Keyser. By 1900, Piedmont, Davis, and Thomas all claimed populations over 2000. Not all new towns reaped similar benefits. Census statistics followed a different trajectory in several other new communities in Mineral and Grant counties along the WVC\&P mainline. Elk Garden, site of the major coal production in Mineral County, peaked at 723 people in 1890. By 1900, the number of its inhabitants declined to 581, with continued decrease afterward. Bayard, in Grant County, maintained a population of around 500 in the final years of the nineteenth century and the first decade of the twentieth century before jumping to over 1000 residents in $1920 .^{5}$

Several factors contribute to population, and they interact in complex ways. The point is that, generally speaking, the railroad opened up new areas for settlement, but was only one factor that led to growth, albeit a major one. Industry constituted another major, and closely related, factor of growth. Newly formed towns such as Davis and Thomas enjoyed close proximity to natural resources. For a few key formative years in the 1880s, Davis served as the southern terminus of the WVC\&P. Extractive enterprises such as mills and mines, refining firms such as coke ovens, manufacturing industries such as tanneries, and various professionals and retailers all located in Davis and Thomas. Towns like Piedmont and Bayard, by contrast, held the extractive industries and some of the professions, but they had far fewer industries such as coke ovens

${ }^{5}$ Twelfth Census of the United States, Population, Vol. 11900 (Washington: Government Printing Office, 1902), 478, 479; Fourteenth Census of the United States, Population, Vol. 1, 1920 (Washington: Government Printing Office, 1922) $313,314$. 
and tanneries that put the natural resources to immediate use. Thus, their populations were not as large as Davis or Thomas.

Regardless of these intricacies, ultimately, all these towns owed their success, directly and indirectly, to extractive industries. The short piece of track in operation in the mid-1880s opened up extensive areas of land. It ran through the heart of the Upper Potomac Coal field. The company owned about 30,000 acres of coal land containing over one million tons of coal spread over approximately ten veins, most notably the Big Vein (Pittsburgh seam) in Mineral County. A boom and saw-mill operated at Shaw, just up the Potomac River from Piedmont. These extensive holdings, coupled with a rail line with direct access to the B\&O, ensured Davis's dominance in the coal and timber businesses in Mineral County. Only one company, the Big Vein Coal Company, competed with WVC\&P operations in that county, and even it relied on Davis's railroad to haul coal to the B\&O. ${ }^{6}$

To the south lay more than two billion tons of untouched coal in Grant and Tucker counties. The gains from his Mineral County holdings alone, along with the promise of greater wealth to the south, made Davis devote almost all his time to coal. The new towns of Davis became the southern terminus of WVC\&P, allowing him to reach the lucrative veins in central Tucker County. In addition to the lands and property owned by the WVC\&P, Davis and Elkins owned thousands more acres through various companies. In 1889, the two formed the Davis Coal and Coke Company. Four years later Davis folded his four other coal companies into the Davis Coal and Coke, making one massive mining enterprise that extended across the Upper Po-

${ }^{6}$ Annual Report of the WVC\&P (Baltimore: W.J.C. Dulany and Co., 1884), 5; Workman, et. al, 67, 68. 
tomac and Elkins fields. The conglomerate absorbed as many other smaller companies as possible. By 1894, the Davis and Elkins interests controlled more than 100,000 acres of coal land. ${ }^{7}$

The railroad allowed others to open large-scale mining operations. Davis's cousins, brothers William and Arthur P. Gorman, operated the Cumberland Coal Company in Tucker County. Davis and Elkins both held stock and served on the board of directors, just as Arthur owned stock and served on the board of the WVC\&P. Production in the Upper Potomac field increased into the early years of the twentieth century, helping to make the Davis Coal and Coke Company the third largest coal producer in the state by $1906 .{ }^{8}$

In addition to coal, both Grant and Tucker counties contained thousands of acres of virgin timber - a profitable mixture of hardwoods, spruce, and pine. ${ }^{9}$ As important as coal was to industrialization in those counties, timber was arguably more important, especially in Tucker County. While only one band saw-mill operated in Grant County, eleven major mills ran in Tucker County from the 1880 s to the 1920s. Saw mills, like coal mines, changed hands quickly during the period, as rapid acquisition of wealth and fierce competition sometimes led owners to sell within just a few years of starting or buying a company. In 1886, J. L. Rumbarger of Indiana opened the J.L. Rumbarger Company in Davis. An experienced hardwood manufacturer, he recognized the opportunity afforded by the railroad and began buying land in the Canaan Valley the year before. In 1887, he sold out to Albert Thompson, originally of Maine. Thompson owned the Blackwater Boom and Lumber Company from 1887 to 1893, when he sold out to W.H. Osterhout and the Blackwater Lumber Company. The company continued to be bought and sold

\footnotetext{
${ }^{7}$ Michael E. Workman, Paul Salstrom, and Philip Ross, Northern West Virginia Coal Fields: Historical Context (Morgantown, WV: Institute for the History of Technology and Industrial Archeology, 1994), 68; H.G..D., "Journal," May 1, 1883; January 11, 1889; Ross, 216.

${ }^{8}$ Workman, et. al., 69.

${ }^{9}$ Lewis, Transforming the Appalachian Countryside, 24, 25.
} 
several times over the next twenty years, until clear cutting forced the West Virginia operations of what was then called the Babcock Lumber and Boom Company to shut down. ${ }^{10}$

As with the Rumbarger Company, investors and businessmen from other states owned most of the major lumber companies operating in West Virginia. Most of those firms were chartered and headquartered out of state as well. In 1888, William Luke and his sons opened the Piedmont Pulp and Paper Company in Maryland across the river from Piedmont, West Virginia, with an office in New York City. By 1894, the company owned 50,000 acres of timber lands in Tucker County which supplied three saw mills in that county. Tucker County contained such large quantities of timber that by 1900 it led the state in capital investments in timber with over $\$ 2$ million. It also numbered in the top four counties in lumber production and saw mills between 1880 and $1920 .^{11}$

The railroad sparked and fueled other industries as well. The growth of the timber industry and the railroad industry led to the rise of the tanning industry in the region, especially in Tucker County, as tanneries used tree bark in processing leather. In 1886, a New York company built a tannery in the town of Davis. That same town became a hub of the livestock trade that characterized the region prior to heavy industrialization. Drovers herded cattle from Tucker, Randolph, Pocahontas, and Pendleton counties to Davis to board trains bound for eastern markets. $^{12}$

\footnotetext{
${ }^{10}$ Roy B. Clarkson, Tumult on the Mountains: Lumbering in West Virginia, 1770-1920 (Parsons, WV: McClain Printing Company, 1964), 84.

${ }^{11}$ Lewis, Transforming the Appalachian Countryside, 98, 99; Lewis, Railroads, "Deforestation, and the Transformation of Agriculture in the West Virginia Back Counties, 1880 -1920," in Appalachia in the Making: The Mountain South in the Nineteenth Century, Mary Beth Pudup, Dwight Billings, and Altina L. Waller, eds. (Chapel Hill, NC: The University of North Carolina Press, 1998), 82. The Piedmont Pulp and Paper Company later became the West Virginia Pulp and Paper Company.

${ }^{12}$ Annual Report of the WVC\&P (Baltimore: American Steam Job Press, 1887), 6, 7. For more on the industrial development of Tucker County, see Cleta M. Long, History of Tucker County, West Virginia (Parsons, WV: McClain
} 
The West Virginia Central and Pittsburg facilitated, and profited from, all of this industrial growth. The Davis railroad, however, could not claim complete self-sufficiency. It was the line out of the mountains. However, once it reached the Potomac River, it depended upon the B\&O to get goods to their final destinations. For the first few years of WVC\&P operations, Davis and his associates had good relations with the B\&O. In 1884, however, after B\&O President John W. Garrett died, relations deteriorated. The new B\&O leaders quickly realized how profitable the WVC\&P was. The larger line also realized that the small West Virginia road was completely at its mercy. The "Senatorial Railroad" could afford to pay whatever the B\&O demanded. $^{13}$

Davis's journal entries and letter books from 1885-1887 are riddled with references to rate and right of way negotiations with the new B\&O leadership, especially with the new president Robert S. Garrett, son of the previous president. Before the end of 1885, it became clear that the younger Garrett would not return to the lower rates his father had charged. Davis and Elkins decided the time was right to make alternative arrangements. A spur of the Pennsylvania Railroad met the B\&O in Cumberland. If Davis could figure out how to get to Cumberland, he could use the Pennsylvania network to haul his freight to markets east and west, bypassing the B\&O completely. ${ }^{14}$

Even after construction began on the new Piedmont and Cumberland Railroad, however, trouble with Garrett continued. While he lost control of the rate issue, Garret persisted in making

Printing Company, 1997); Homer Floyd Fansler, History of Tucker County, West Virginia (Parsons, WV: McClain Printing Company, 1962); Hu Maxwell, History of Tucker County, West Virginia (Kingwood, WV: Preston Publishing Company, 1884),; and Pearle G. Mott, History of Davis and Canaan Valley (Parsons, WV: McClain Publishing Company, 1972).

${ }^{13}$ Charles M. Pepper, The Life and Times of Henry Gassaway Davis, 1823-1916 (New York: The Century Co., 1920), 103; Ross, 158, 159.

${ }^{14}$ H.G..D., "Journal,” September 14, October 9, 15, 30, November 13, 27, 1885. 
trouble over the right of way, especially in West Virginia. After significant haggling and a showdown between $\mathrm{P} \& \mathrm{C}$ and $\mathrm{B} \& \mathrm{O}$ workers that nearly led to bloodshed, the two men finally reached an agreement. On April 10, the Piedmont and Cumberland Railroad, running from West Virginia Junction to Cumberland, Maryland, was completed. With the B\&O's hold over the WVC\&P broken, Garrett became more amenable to re-negotiating rates. Using his political connections, Davis also secured the contract to carry the U.S. mail. This gave Garrett further incentive to negotiate, as any action construed to be hampering postal delivery could bring federal intervention. $^{15}$

\section{Choices: Selecting Routes and County Seats}

The struggle to build the P\&C dominated the years between 1885 and 1887 . After reaching the town of Davis in 1884, the WVC\&P made no further southern progress until 1887 (the line to Thomas built in 1885 was an extension constructed to the west to provide access to more coal and timber), when surveying for a route into Randolph County began. Davis and the WVC\&P Board had already decided to take the line south into Randolph County, with the intention of reaching the Gauley and Elk headwaters by way of the forks of Cheat. From Addison in Webster County, he would build to Charleston, giving him access to the Ohio Valley, which would provide good market access in all directions. ${ }^{16}$ Yet the exact route remained unclear. Traditional trade routes ran through St. George, the Tucker County seat, to Rowlesburg in Preston County, where the $\mathrm{B} \& \mathrm{O}$ met the Cheat River. The Cheat and two tributaries flowing down from the south, the Black Fork and the Shavers Fork, were fine rafting rivers. ${ }^{17}$

\footnotetext{
${ }^{15}$ Clarke, West Virginia Central and Pittsburg Railway, 27-34; H.G.D., “Journal,” May 20, 1887; Ross, $160,161$.

${ }^{16}$ Letter from H.G. Davis to James Parsons, September 21, 1886. Series 16, Box 234 of the Henry Gassaway Davis Papers. Located in the West Virginia Collection at the Wise Library of West Virginia University, Morgantown, WV; Annual Report of the WVC\&P (Baltimore: W.J.C. Dulany and Co., 1888), 5.

${ }^{17}$ Lewis, 38.
} 
Davis briefly considered going further west in Tucker County to St. George before heading south. However, as early as January 1887 he already had plans to bypass the town. Going through the Tygart Valley, rather than past the forks of Cheat, just made more sense - it was less mountainous and contained much better agricultural land. This route would come close to St. George, passing just six miles to the south, but would completely redirect trade. As Davis noted in a letter to his brother Tom and Elkins, the new proposed route "would stop much timber now floated to the $\mathrm{B} \& \mathrm{O}$ and the Penna. Roads below." 18

On July 20 of that year he, Elkins, and a number of others took an extensive trip through the mountains looking for the most profitable land and the best ground on which to lay track. From the town of Davis he and his companions traveled west on horseback to St. George before heading south into the Tygart Valley in Randolph County and on into Webster County. ${ }^{19}$ He already knew of the Roaring Creek coal seam near Leadsville in Randolph County (the Roaring Creek coal also extended into neighboring Barbour County), but he found more timber than he expected. While Davis left sufficient details in his journal about where he went and what he found, he wrote almost nothing about how the trip shaped his opinion of exactly where the route would go.

Since the beginning of the year he had been in contact with his agents in Beverly, Messrs. Butcher and Harding, about securing a right of way through Beverly. Apparently, he expected land for a depot and free right-of-way in Beverly. However, Davis did not deal with the right of way issue on this trip, and, in fact, had been downplaying the possibility of building a railroad

\footnotetext{
${ }^{18}$ Letter to from H.G. Davis to Elkins and Tom Davis, January 1887. Series 16 Box 234. It would also make sense to by-pass St. George if the forks of Cheat route were followed. However, Davis made no indication that he intended to by-pass the county seat until he selected the Tygart Valley route.

${ }^{19}$ H.G..D., “Journal,” July 20-27, 1887.
} 
through the Tygart Valley for months in order to gain leverage on acquiring land. If people knew his intentions, the price of land would increase significantly. ${ }^{20}$

As he headed back to the town of Davis, H.G. Davis finally commented briefly on the planned route. The passage was telling. He still described the route going to Beverly and thence on to Addison in Webster County, but he did not mention St. George. Instead, he traced the path south from Parsons, a new community where the Shavers Fork and the Black Fork met to form the Cheat River. This entry was the last mention of St. George and the first of many mentions of Parsons in his diary. ${ }^{21}$ The exact reasons for cutting off those six miles to St. George were never stated. It seemed that Davis was looking for the most direct and most profitable route south. It was less expensive and more lucrative to go directly south to Parsons to Beverly.

Oddly, he made no mention of the Beverly right of way issue in his journal entries. He had made no real effort to acquire it and Davis continued to be optimistic that it would be secured. At the same time, the trip put the Roaring Creek coal in his mind, and a suggestion from a friend in Preston County intrigued him. Why not take the road through the entirety of the Roaring Creek load? This would involve coming south to Leadsville and then west through Belington in Barbour County. Under this plan, Davis would build to Buckhannon and then to Charleston. He instructed James Parsons, the WVC\&P surveyor, to survey the Beverly and Belington routes and give him detailed reports on both. ${ }^{22}$ This plan would mean focusing entirely on coal land development and foregoing the rest of the timber harvesting.

\footnotetext{
${ }^{20}$ Letter from H.G. Davis to J.F. Harding, March 5, 1887. Series 16 Box 234.

${ }^{21}$ H.G..D., “Journal,” July 27, 1887.

${ }^{22}$ Letter from H.G. Davis to John Brannon, August 13, 1887; Letter from H.G. Davis to Butcher and Harding, November 23, 1887; Letter to James Parsons, December 19, 1887. Series 16 Box 234.
} 
By the beginning of 1888 , the decision had been made to take the line through the Tygart Valley up the Tygart River. Going south to Beverly would allow Davis, Elkins, and their associates to take advantage of the vast timber reserves of the mountain counties, most of which stood unclaimed. However, the populace of Beverly was not made privy to this knowledge. Davis told head surveyor James Parsons to secure the right of way from Parsons to Beverly, and by keeping Beverly residents in the dark about his real plans, Davis hoped to keep the price for the right of way low, and perhaps even secure it at no cost. ${ }^{23}$

Over the course of 1888 and 1889, Davis continued to demur on questions regarding the extension of the WVC\&P up the Tygart Valley. Leading citizens of Beverly, including a lawyer, the mayor, and a doctor, increasingly inquired about the future of the railroad in their town. They wanted the railroad and were willing to cooperate with Davis. Davis cagily responded to their queries that he had not chosen a final route beyond Leadsville. Even his agents in the county, Butcher and Harding, remained in the dark. ${ }^{24}$ For the time being, the line stopped in Leadsville. In 1888, Davis and Elkins founded a new town around that tiny village. They called the new town Elkins, and it became the southern terminus for the WVC\&P mainline in $1889 .^{25}$

The fact that the WVC\&P would not be going through St. George or, at least for the time being, Beverly, provided a perfect opportunity for both local elites and Davis and Elkins to increase their power and position. A group of landowners in southern Tucker County, led by the Parsons family, decided to start a new town with the intending that it would become the county

\footnotetext{
${ }^{23}$ Letter from H.G. Davis to James Parson, January 7, 1888; Letter from H.G. Davis to James B Canfield, February 28, 1887. Series 16 Box 16.

${ }^{24}$ Letter from H.G. Davis Butcher and Harding, July 27, 1888; Letter from H.G. Davis Dr. G.W. Yokum, September 8, 1888; Letter from H.G. Davis to J.B. Ward, September 10, 1888. Series 16, Box 234. Letter from H.G. Davis to J.B. Ward, January 26, 1889; Letter from H.G. Davis to James A Bent, March 1, 1889. Series 16 Box 235.

${ }^{25}$ Don Teter, “Elkins,” Tygart Valley Press, February 15, 1978.
} 
seat because it would have the railroad. Men who sold land to H.G. Davis came to dominate the town, becoming some of the wealthiest and most influential in the county. The railroad arrived in 1889, on its way to Elkins, and significantly increased the population and economic strength of the new town, which was named Parsons, after Ward Parsons (no relation to James Parsons, the WVC\&P head surveyor), the leader and chief financial backer of the group. ${ }^{26}$

As the local elites of Tucker County worked to establish themselves, Davis and Elkins were busy in Randolph County. Their indecision about the route proved fortuitous. Between late 1888 and 1890, Davis and Elkins worked tirelessly to buy up as much property as possible around Elkins. While both men had a reasonable idea of where the railroad would go, they wanted the flexibility to build shops and extensions as needed. Securing the basic right of way through Elkins was relatively simple, but throughout 1889 and 1890 they struggled to negotiate deals to purchase all the property they wanted. Furthermore, Davis still considered idea of extending the rail line west to Barbour County and beyond. ${ }^{27}$

Meanwhile, the people of Beverly continued to ask for the railway. They wanted it, but the major issue was about the cost of the right of way. Arguing (probably disingenuously) that a Beverly extension would not be profitable, Davis believed it was unreasonable for them to expect him to pay for a right of way and land for a station. Over the next several months, it seems the citizens complied with his wishes. In May 1891, the mayor sent a petition signed by himself,

\footnotetext{
${ }^{26}$ Homer Floyd Fansler, History of Tucker County, West Virginia (Parsons, WV: McClain, 1962), 248-249; Annual Report of the WVC\&P (Baltimore: W.J.C. Dulany, 1890), 6.

${ }^{27}$ Letter from H.G. Davis to James Parsons, December 10, 1888; Letter from H.G. Davis to James Parsons, January 2 , 1890. Series 16, Box 234.
} 
Harding, and several citizens to Davis requesting that the railroad come to their town. Finally, the railroad arrived. Construction began that same spring and was completed by November. ${ }^{28}$

The course of the railroad had a direct, immediate impact on the political landscape of Randolph and Tucker counties. In the final years of the nineteenth century, each county experienced a struggle over the seat of its government that exemplified the broader cultural and societal tensions of the period. The county seat battles represented the conflict between industrialists and agrarians in the late nineteenth and early twentieth centuries. The moving of both county seats constituted one more indicator of the transformation from an agrarian economy and society to an industrial one. ${ }^{29}$

Between 1890 and 1893, Tucker County held several highly contested referendums to determine whether its county seat would remain in St. George or move to Parsons. Eventually Parsons won, but the people of St. George refused to submit without a fight. Alleging election irregularities, they attempted to secure an injunction from the state Supreme Court of Appeals to invalidate the results. Realizing that the actual transfer of power and county records could take months if such an effort were successful, a group of six hundred men from Parsons decided to take matters into their own hands. They intended to take the county records and courthouse furnishings themselves and establish the government in Parsons, as per the election results. A small band of resistors gathered at the courthouse in St. George, but disbanded before the larger Parsons contingent arrived and moved the county government to Parsons. Although the railroad had not come to Parsons yet, the town fathers knew that trains would bring growth and that St. George would be largely isolated from the rest of the county. The results of the plebiscite of

\footnotetext{
${ }^{28}$ Letter from H.G. Davis to T.P.R. Brown, September 2, 1890; Letter from H.G. Davis to S.H. Bosworth, May 9 , 1891. Series 16 Box 235; Annual Report of the WVC\&P (Baltimore: Wm. J. C. Dulany and Co., 1899), 20.

${ }^{29}$ Lewis, 217.
} 
1893 were never challenged and the men from Parsons faced no repercussions. A few weeks later, in compliance with the terms of the vote, the county court formally moved the county seat to Parsons. ${ }^{30}$

Four years later, a similar situation developed in Randolph County. Davis's indecision about where to build his route allowed Elkins to grow rapidly and become a center of commerce, at Beverly's expense. Davis and Elkins saw no reason why the county seat should not locate in the bustling new town. Historian Ronald L. Lewis notes that there is no "smoking gun" connecting these absentee elites to the actions of the local elites in Tucker County, although there were close business connections and H.G. Davis would certainly have been well aware of the situation. In Randolph County, on the other hand, he and S.B. Elkins were directly involved in making the new town of Elkins the county seat. ${ }^{31}$

There were some highly controversial votes and legal battles over the location of the county seat between 1897 and 1899. Elkins finally won after a circuit judge ruled that 312 ballots that had been cast in favor of Beverly were illegal, thereby giving Elkins the required threefifths majority. However, a circuit judge ordered a forty-two day stay to give Beverly attorneys time to prepare an appeal for the West Virginia Supreme Court of Appeals. Further delay seemed intolerable to Elkins residents, and 600 of them planned to travel to Beverly by train and do the job themselves. Fifty Beverly men entrenched around the courthouse, determined not to surrender. While cooler heads prevailed and the Elkins contingent backed down, Beverly soon lost its position of political prominence. The county seat moved to Elkins after the Court of Appeals

\footnotetext{
${ }^{30}$ Fansler, 252-256. See also Homer Floyd Fansler, "The Tucker County Seat War," Parsons Advocate, April 16, 1959.

${ }^{31}$ Lewis, 224.
} 
refused to rehear the case, effectively ruling in favor of the city of Elkins. Economic and social declined in Beverly followed. ${ }^{32}$

As the county seat battle raged, industrialization in Randolph County proceeded at a brisk pace. In 1900, Randolph County ranked in the state second behind Tucker in capital invested in industry with just under $\$ 2$ million. As in Tucker County, the Davis railroad paved the way for development, but the Davis interests failed to completely monopolize industry in the county, including the Iron Horse. The Belington and Beaver Railroad, an independent line, opened in 1891. It extended west from Elkins to the Roaring Creek coal, and then north to Barbour County. Davis and Elkins never owned the B\&B, but it did serve "as a de facto extension of the WVC\&P mainline," giving them another route into the Roaring Creek coal in addition to the WVC\&P extension in Belington that opened the following year. ${ }^{33}$

The Davis Coal and Coke Company opened mines in the Roaring Creek region, as did another Davis firm, the Junior Coal Company. Smaller mining operations, such as companies owned by F.P. Rease and O.C. Womelsdorf, enjoyed considerable success in the new towns of Womelsdorf (Coalton) and Harding, both lying just west of Elkins. Davis acquired these competitors in 1902 when the Junior Coal Company purchased them from the Berwind-White Coal Company, which had previously bought out the original owners. ${ }^{34}$

Due to its low sulphur content, Roaring Creek coal was well-suited for making coke. In 1892, the Junior Coal Company began erecting fifty coke ovens along the B\&B at Harding, and

\footnotetext{
${ }^{32}$ Donald L. Rice, Bicentennial History of Randolph County, West Virginia, 1787-1987 (Elkins, WV: Randolph County Historical Society, 1987), 40-45.

${ }^{33}$ Workman, et. al., 94. Annual Report of the WVC\&P (Cumberland, MD: Frank B. Jervey, 1893), 19. Davis ultimately decided to build extensions to Beverly and Belington at the same time. Timber drew Davis to Beverly, but it was the B\&O's interest in a route to Belington that prompted Davis to lay tracks in that direction. See Letter from H.G. Davis to C.W. Dailey, May 5, 1889. Series 16 Box 234.

${ }^{34}$ Annual Report of the WVC\&P (Cumberland, MD: Frank B. Jervey, 1893), 5, 6.
} 
coke production commenced in 1900 with thirty-five beehive ovens in use. The company built 200 more at Coalton between 1902 and 1904, but lower than expected market demand meant only half of these operated in 1904. At the same time, the Maryland Smokeless Coal Company, operating two mines in Weaver, opened 135 coke ovens. By 1904, 520 coke ovens operated in Randolph County. With the Davis Coal and Coke Company's acquisition of the Maryland Smokeless coke ovens, Davis and his associates owned a significant number of them. Randolph County coke production peaked in 1907, but production levels remained high through $1920 .^{35}$

As lucrative as coal was in Randolph County, timber provided an even greater industrial boom, even though heavy logging started well after major coal production. Unlike Tucker County where several large mills opened in the late 1880 s and 1890 s, only a few large band saw mills opened in Randolph County before the turn of the century. All of those existed in communities with direct access to the railroad. ${ }^{36}$ The growth of the timber industry there clearly demonstrates the connection between the railroad and all other industrial activity. While Davis and Elkins recognized the potential for timber, they concerned themselves almost exclusively with coal and coke production in Randolph County. Thus, until the final years of the nineteenth century, their railroad extended only to the coalfields in the northwestern and central parts of the county. They relied on other entrepreneurs to tackle the challenge of harvesting the richest hardwood forests of the southern and eastern districts.

In the early 1890s, the Dry Fork Railway Company began logging on thousands of acres in northeastern Randolph County and southwestern Tucker County. By 1895, that small line ran from Hendricks in Tucker County to Horton in Randolph County, where the company operated a

\footnotetext{
${ }^{35}$ Annual Report of the WVC\&P (Cumberland, MD: Frank B. Jervey, 1893), 5,6; Workman, et. al., 101.

${ }^{36}$ Clarke, 35-36.
} 
mill capable of producing 100,000 board feet a day. The company also opened a town named Whitmer, after company president Robert Whitmer. The WVC\&P ran an extension to Horton to link up with the Dry Fork Railway. Although still committed to coal, Davis and his associates recognized the extension eastward "open[ed] up an agricultural district as well as many thousands of acres of valuable timber lands." ${ }^{, 37}$

\section{Conquering New Heights}

As the eastern part of the county opened, the southern section held similar promise of riches. In July 1895, Davis took a trip to scout a possible southern route for his railroad. The proposed route would run southeast from the WVC\&P mainline up the Glady Fork of Cheat and down the West Fork of the Greenbrier River. The extension would go to Huntersville before splitting into an eastern branch and a southern branch. The eastern one would traverse the mountains into Virginia, going to Monterey and Staunton. The southern line would continue to White Sulphur Springs, where it would connect to the Chesapeake and Ohio Railway. ${ }^{38}$

As with many other proposed rail lines in the late nineteenth century, this one never materialized, or at least not in the way initially conceived. Getting to Virginia, or even to Pocahontas County just south of Randolph, proved difficult. Going from the Potomac to the Tygart River in Randolph County was not easy either, but relatively open river valleys made it possible to cut through fewer mountains. Such valleys going to the southeast were rarer. Getting to Pocahontas County and Virginia would require cutting through and going over more mountains.

Faced with substantial topographical obstacles, Davis and his associates started modestly. By 1899, crews completed an extension to Huttonsville, about eleven miles south of Beverly,

\footnotetext{
${ }^{37}$ Annual Report of the WVC\&P (Baltimore: W.J.C. Dulany and Co., 1896), 6; Annual Report of the WVC\&P (Wm. J.C. Dulany and Co., 1897), 7; Clarke, 132.

${ }^{38}$ H.G..D., “Journal,” July 18-23, 1895.
} 
two years after Huttonsville citizens actually came to Elkins to petition Davis in person to build an extension of the WVC\&P to their town. ${ }^{39}$ This occurred on the eve of the county seat controversy. Apparently, residents of the southern part of the county already understood what a railroad could do for them.

They were correct. Serious timbering in the mountains of southern Randolph County commenced before that branch line was completed. As in Tucker County, seasoned lumbermen from out of state quickly erected saw mills. When the first trains traveled over the new route in early 1899, industrialists were ready. In the early 1900s coal mines and more mills opened in southern Randolph County. All along the WVC\&P mainline, from the Potomac to the Tygart, industries operated at full capacity and new ones opened nearly constantly. As happened previously and afterwards, outside interests rushed to purchase timber land and erect saw mills. The Pennsylvania farm machinery company Hench and Dromgold built a mill in the new town of Mill Creek, between Beverly and Huttonsville. Two other mills soon operated there as well. ${ }^{40}$

Thus, at the turn of the twentieth century, optimism ran high, as the Iron Horse ran nearly the entire length of Randolph County, the largest in West Virginia. In just over a decade, new communities dotted the landscape, more and more of it becoming increasingly bare as large-scale logging took its toll. Towns such as Davis, Thomas, Parsons, and Elkins, each essentially nonexistent ten or fifteen years prior, blossomed into booming industrial towns, most of them boasting populations of more than 2000 people. As the southern terminus for the WVC\&P mainline, the town of Elkins became the personal business headquarters for both Henry Gassaway Davis and Stephen B. Elkins, although neither lived there year-round. The new town became a small

\footnotetext{
${ }^{39}$ Annual Report of the WVC\&P (Baltimore: W.J.C. Dulany and Co., 1900), 7-9.

${ }^{40}$ Clark, 35, 36, 99, 100; Annual Report of the WVC\&P (Baltimore: W.J.C. Dulany and Co., 1900), 19; Clarkson, Tumult on the Mountains, 36.
} 
financial hub and white-collar trade center, with banks, retail stores, doctors, and lawyers. It also attracted manufacturing enterprises such as tanneries and furniture-making companies. ${ }^{41}$

This optimism was well founded, at least in the short term. While the latest southern extension of the WVC\&P opened up thousands of acres of new timber land, the largest wave of timber production was just on the horizon. Davis did not forget about going to Pocahontas County, and he still harbored dreams about reaching Virginia. In October 1900, travelling in wagons, Davis, Elkins, and a small group of their business associates left Huttonsville on a protracted expedition to scout a railway route from the "Forks of Greenbrier to deep water on Potomac Bay of York River." ${ }^{42}$

There is no Potomac Bay. Davis was probably referring to the Chesapeake Bay, into which the York River flows, or the smaller Mobjack Bay, a smaller bay just north of where the York flows into the Chesapeake, on the western side of the larger bay. Regardless, Davis had yet another ambitious project. Of course, he did not plan to build a single, new railway all the way to the Atlantic Ocean, nor did he go all the way to the Virginia shore on this trip. Rather, as with many of his other projects, he planned to tackle the most difficult geographical challenges and link up with existing lines, which would provide him with another outlet to eastern and even world markets.

In a 1901 letter to Henry Fairfax, governor of Virginia, Davis disclosed that he wanted to link up with the Southern Railway in or near Harrisonburg. Apparently, as in West Virginia,

\footnotetext{
${ }^{41}$ Twelfth Census of the United States, Population, Vol. 1, 1900 (Washington: Government Printing Office, 1922), 313, 314. For more on Parsons, see Note 10 above. For more on Elkins and Randolph County development, see Donald L. Rice, ed., The Elkins Centennial Album, 1890-1990 (Parson, WV: McClain Printing Company, 1990); Donald L. Rice, ed., Randolph 200: A Bicentennial History of Randolph County, West Virginia (Marceline, MO: Walsworth Press, 1987); William H. Rice, Elkins, West Virginia, 1889: The Magic City of the Wilderness (Parson, WV: McClain Printing Company, 2007); and Hu Maxwell, The History of Randolph County, West Virginia (Morgantown, WV: The Acme Publishing Company, 1898).

${ }^{42}$ H.G..D., "Journal," Oct 14-21.
} 
some local interests in Virginia were willing to charter a railroad in that state to connect with the Southern in Virginia and one of Davis's roads on the state line. Davis was quick to mention the importance of using local incorporators. "For the present we think it best we [Davis, Elkins, and their associates] should not be known in the matter as it may bring on opposition from other railroads." In late February of that same year, the Virginia legislature granted a charter to the Central Railway, and the governor signed it. Here was the access to the South that Davis wanted. From Harrisonburg, West Virginia timber, coal, and manufactured items could reach the Chesapeake. They could also reach Lynchburg, Virginia, and from there make their way to the Deep South. $^{43}$

Heading south, Davis and his partners confronted more than just nature. For the first time, they confronted other powerful business interests already in the region. In the first two decades after the Civil War, Davis vied with J.N. Camden for control of North Central West Virginia. In 1890, the two divided the area between themselves. Davis and his allies took most of the high mountains and some of the northern counties of the interior, while Camden got the deep central interior, including the vast Caperton tract and a sliver of southwestern Randolph County that bordered Webster and Upshur counties and was drained by the Buckhannon River. ${ }^{44}$ In their respective areas, Davis and Camden led the way in industrial development.

\footnotetext{
${ }^{43}$ Letter from H.G. Davis to Henry Fairfax, February 8, 1901. Series 15 Box 214 of Henry Gassaway Davis Papers, located in the West Virginia Collection, Wise Library, West Virginia University, Morgantown, WV. Letter from Davis to Samuel Spencer, February 21, 1901. Series 15 Box 214, H.G. Davis Papers; Letter from Davis to D.A. Willey, February 23, 1901. Series 15 Box 214, H.G. Davis Papers.

${ }^{44}$ Williams, West Virginia and the Captains of Industry, 25; Rice, Randolph 200, 68. In the 1890s and early 1900s, Camden built a series of lines connecting the southwestern edge of Randolph County with neighboring counties in order to increase coal and lumber production and transportation. The mileage of these lines in Randolph was extremely small, negligible in comparison to the amount of track the WVC\&P laid in the area. For more on Camden's railroad enterprise, see Alan R. Clarke, The West Virginia and Pittsburgh Railroad: The B.\&O. 's Road to the Hardwoods (Charleston, WV: Quarrier Press, 2008).
} 
In Pocahontas County, other capitalists laid the foundation for industrial growth. The pattern, however, was the same. Local elites initiated economic transformation by purchasing vast tracts of land. They continued to increase their power by starting their own industries and encouraging outside interests to establish operations within the county as well. John T. McGraw of Grafton, another leading figure in the state Democratic Party, moved into the Greenbrier River Valley (cutting through Pocahontas and Greenbrier Counties) as early as 1882 when he and two business partners, anticipating the explosion of extractive industries, purchased enormous quantities of land. ${ }^{45}$ After the initial purchase they waited. The Chesapeake and Ohio Railway completed its line from White Sulphur Springs to Huntington in 1873 . The company already planned to extend north up the Greenbrier Valley. Financial difficulty delayed these constructions, but opening the southern coal belt significantly increased revenue over the next twenty years. Now, wrote $\mathrm{C} \& \mathrm{O}$ historian Thomas Dixon, "the most ambitious ... expansion was built not to tap rich coal resources, but to bring lumber and farm produce to market."

Despite the coal profits, the Panic of 1893 delayed construction of what became known as the Greenbrier Branch of the C\&O until the late 1890s. McGraw's patience seemed to pay off, and he sprang into action early in the decade. In 1891, he and other powerful state businessmen/politicians formed the Pocahontas Land Development Company. They auctioned off land around the tiny hamlet of Marlin's Bottom along the Greenbrier River to small local investors. In 1893, county residents voted to move the county seat from Huntersville, just six miles to the west but not immediately adjacent to the river, to the newly renamed Marlinton (formerly Mar-

\footnotetext{
${ }^{45}$ John Hennen, "Benign Betrayal: Capitalist Intervention in Pocahontas County, West Virginia, 1890-1910,” West Virginia History 50, (1991) : 47, 48.

${ }^{46}$ Thomas W. Dixon, Jr., "The Chesapeake and Ohio Railway in Greenbrier," Journal of the Greenbrier Historical Society 3, no. 4 (1978) : 33, 52.
} 
lin's Bottom). Unlike the Randolph and Tucker county seat wars, moving the Pocahontas County seat proved comparatively easy. By selling land to locals, McGraw gave more people a vested interest in siding with him. Like the situations in Randolph and Tucker counties, the outcome for the winners and losers was the same. Huntersville's population remained about the same -- approximately 100 residents - between 1890 and 1910, but by 1914, Marlinton boasted a population of 1800. Commercial and industrial growth in Huntersville ground to a halt, while over the course of about twenty-five years Marlinton exploded. Professionals, retailers, and small tradesmen made Marlinton home. While it never reached the size of Elkins or Parsons, like those towns it demonstrated the transformative effect of the railroad and the power of the development faith. Huntersville, like St. George and to a lesser extent Beverly, demonstrated the other side of this development coin. ${ }^{47}$

The hesitation of Davis to build the road to Beverly consigned that town to limited growth into the early twentieth century. By 1890, just two years after it was founded, Elkins already had 737 people, about twice Beverly's population of 343 . By the turn of the century, Elkins boasted more than 2000 residents; by 1910, it was the largest town along the WVC\&P mainline with 5,260 and reached 6,788 residents in 1920. By contrast, Beverly hovered under 500 through 1920. Huntersville and St. George, both bypassed by the train completely, remained very small. Huntersville does not even appear in the incorporated places list in the census after 1900, while the population of St. George never exceeded 250 through 1920.

Parsons, the new county seat of Tucker County, demonstrates that the political center of a county was not always the most populous town or the economic center. By 1900, the population stood at only 678, far smaller than the older industrial towns of Davis and Thomas. Through

\footnotetext{
${ }^{47}$ Hennen, 3; Lewis, Transforming the Appalachian Countryside, 197, 198.
} 
1920, Parsons remained smaller than both Davis and Thomas, although Parsons did reach 2000 inhabitants by $1920 .^{48}$

Another point of comparison between Marlinton and the two other new county seats in the highlands merits mention. Davis and Elkins, the major railroad developers in Randolph and Tucker counties, played leading roles in forming the towns of Elkins and Parsons and ensuring that they became the county seats and that the railroad would run through them both. This situation did not occur in Pocahontas County. McGraw moved the county seat before construction on the Greenbrier Branch began. Once surveying commenced, there was no guarantee that the line would come to Marlinton. Davis believed his WVC\&P extension in Huttonsville made the best launching point for timbering the Pocahontas spruce. He also thought the $\mathrm{C} \& \mathrm{O}$ would not start construction without his approval. Furthermore, the $\mathrm{C} \& \mathrm{O}$ considered a number of different routes north. $^{49}$

Unlike their previous forays into the mountains, Davis and Elkins now had to work with other major industrial players. Davis grossly underestimated the C\&O. The West Virginia Pulp and Paper Company purchased thousands of acres of land in Pocahontas County and was in the process of building a new paper mill across the mountains in Covington, Virginia. It was the time to build; the only question remained where. Surveyors considered a couple of routes through Huntersville, which would have bypassed Marlinton. McGraw, of course, favored Marlinton. To help his cause, he chartered two companies in 1898, the Greenbrier Valley Construction Company and the Greenbrier River Lumber Company.

\footnotetext{
${ }^{48}$ Twelfth Census of the United States, Population, Vol. 11900 (Washington: Government Printing Office, 1902), 478, 479; Fourteenth Census of the United States, Population, Vol. 1, 1920 (Washington: Government Printing Office, 1922) $313,314$.

${ }^{49}$ William Price McNeel, The Durbin Route: The Greenbrier Division of the Chesapeake and Ohio Railway (Charleston, WV: Pictorial Historical Publishing Company, 1985), 14, 15.
} 
McGraw intended for the Construction Company to build what was known at the time as the Greenbrier Railway. In 1897, a number of people connected to the $\mathrm{C} \& \mathrm{O}$ chartered the Greenbrier Railway Company. With the $\mathrm{C} \& \mathrm{O}$ owning 45 percent of its stock, the Greenbrier effectively served as a C\&O subsidiary until 1903 , when it was completely absorbed by the larger line. While the Greenbrier Railway leased itself to the $\mathrm{C} \& \mathrm{O}$ for use, the $\mathrm{C} \& \mathrm{O}$ issued bonds for payment on construction. ${ }^{50}$ Internal divisions within the leadership of the smaller railroad plagued the organization during the final years of the nineteenth century. They could reach no consensus on which route to take. Meanwhile, McGraw, in his continuing bid to secure a route that followed the Greenbrier River, labored to secure rights of way through several small communities in Greenbrier and Pocahontas counties. His efforts proved doubly successful; not only did he gain the rights of way, but his actions also helped persuade the Board to choose the river path, meaning that Marlinton would get the railroad. Construction finally began in 1899, with several different crews began working at the same time at various places along the route. By October of 1900, the trains rolled into Marlinton. Two years later trains pulled into Durbin, the northern terminus of the Greenbrier branch. ${ }^{51}$

The timing proved perfect. In early 1900, the West Virginia Pulp and Paper Company, having just merged with the Morrison and Cass Paper Company of Pennsylvania, built a logging camp at the new town of Cass, where Leatherbark Run empties into the Greenbrier River. The railroad reached Cass in December of that year, and in less than two months, the first shipment of

\footnotetext{
${ }^{50}$ Greenbrier Railway Company Annual Report, 1899, 13-15, Box 1, Folder 1.1 Greenbrier Railway Company, Records, Minutes, 1897-1901, Chesapeake and Ohio Historical Society, Clifton Forge, Virginia.

${ }^{51}$ McNeel, 17, 18. Thomas W. Dixon, Jr., Chesapeake and Ohio Allegheny Subdivision (Alderson, WV: Chesapeake and Ohio Historical Society, 1985), 44.
} 
pulp wood left for the pulp mill in Covington. In 1902, the first of several large band mills commenced operation. $^{52}$

Along with Randolph and Tucker, Pocahontas County became one of the three leading timber producing counties in the state. Cass typifies the success, and strategy, of the logging industry in Pocahontas County. Several rail spurs left Cass to access the old growth spruce that covered the mountains. The West Virginia Spruce Lumber Company (eventually acquired by the West Virginia Pulp and Paper Company) band saw at Cass, the largest in the county, produced 60,000 feet a day. In 1903, the Spruce Company added a second band mill, increasing capacity to 150,000 feet a day and requiring the addition of three more work camps. The mills ran nearly constantly, but at one point, the company laid off hundreds of men due to overproduction. ${ }^{53}$

Overall, timber production in West Virginia peaked in 1909. However, the Pocahontas County forests contained so much wood that, despite constant logging, its mills did not reach peak production until the early 1920s. Company lands on Cheat Mountain were not clear cut until 1926, and primary logging operations shifted to company lands on the Elk River, southwest of Cass. While lumber remained the town's raison d'etre, five coal mines, three farms, and a company store also operated there. In addition to the operations at Cass, about twenty more large band saws operated in Pocahontas County between 1900 and 1920, with nearly thirty circular saw mills running as well. Tanneries came into Marlinton and Frank, utilizing the thousands of pounds of bark collected at the saw mills. ${ }^{54}$

\footnotetext{
${ }^{52}$ Roy B. Clarkson, On Beyond: Leatherbark, The Cass Saga (Parsons, WV: McClain Printing Company, 1990), 177180; Dixon, Chesapeake and Ohio Allegheny Subdivision, 45.

${ }^{53}$ Lewis, Transforming the Appalachian Countryside, 84; Clarkson, On Beyond Leatherbark, 134, 135.

${ }^{54}$ Lewis, Transforming the Appalachian Countryside, 84; Clarkson, 19, 20, 85-88. For more on Pocahontas County economic development, see Jane Price Sharp and William Price McNeel, eds., History of Pocahontas County, West Virginia, 1981: Birthplace of Rivers.
} 


\section{The Coal and Iron Railway and the End of the Line}

The C\&O/McGraw decision to come north without consulting Davis put him at a distinct disadvantage. He still wanted a connection to Virginia and access to the ore-rich region along the mountainous West Virginia/Virginia border, but unlike his previous railroad endeavors, he was the late-comer. The Greenbrier branch proceeded rapidly up the Greenbrier Valley in 1900 while Davis and his associates scrambled to get their own project underway. Originally, he wanted to connect with the $\mathrm{C} \& \mathrm{O}$ via Huttonsville. However, surveys of the region southeast of Huttonsville indicated that route would be extremely costly to build, requiring "heavy grades and several tunnels." There would be no more extensions of the WVC\&P. The new line, the Coal and Iron Railway, a subsidiary of the WVC\&P, would go east from Elkins and then follow the Shavers Fork of the Cheat River south into Pocahontas County. ${ }^{55}$

Unlike Mineral, Grant, Tucker, and Randolph counties, in which the outside industrialist Davis dealt with aspiring local elites and farmers, the race to industrialize Pocahontas County pitted industrialist against industrialist. The showdown was not bitter, ugly, or ruthless, but it demonstrated that the capitalists did not stand completely above the processes they started. The deck they stacked could in fact be stacked against them. Unlike the locals, however, the industrialists possessed the economic resources to compete with each other on equal terms.

Coming into Pocahontas County, and venturing farther into eastern Randolph County required Davis to purchase land and negotiate right of ways with other major entrepreneurs -- people who knew the true value of the objects in question. In early 1900, Davis wrote to John G. Luke of the West Virginia Pulp and Paper Company asking to buy a right of way for the C\&I

\footnotetext{
${ }^{55}$ Annual Report of the WVC\&P (Washington: Gibson Bros, 1901), 11, 12; Clarke, 107-120; Letter from H.G. Davis to J.W. Marshall, December 6, 1890. Series 16 Box 235; Letter to H.G. Davis to Floyd J. Triplett, February 23, 1901. Series 15 Box 214, H.G. Davis Papers.
} 
through WVP\&P property. That same spring, he bought thousands of acres of land from John McGraw in Pocahontas County and in neighboring Virginia. Neither Luke nor McGraw showed any hesitation to work with Davis. ${ }^{56}$

These two cases, two important incidents for the future of the Coal and Iron road, reveal how the landscape of West Virginia, and the mountain counties in particular, had changed. Virgin timber fell and ancient coal deposits surfaced, but a new elite appeared and dealt with affairs among themselves, rarely needing to consult the old guard. These "Ironheads" may have had some local ties, but they moved smoothly and seamlessly among local, regional, and national circles. More importantly, they developed national concerns. They believed in the "development faith" and possessed the resolve and the resources to put that faith into practice.

Davis and his partners now had to share the mountains, but that did not dampen their design on greater access to national and world trade. Privately, Davis appeared disappointed and frustrated that construction of his C\&I lagged so far behind the Greenbrier line. He wanted to get as far into the Greenbrier Valley as possible, but by early 1901, construction ran behind schedule and he conceded that he would have to meet the $\mathrm{C} \& \mathrm{O}$ branch line in Durbin, near the forks of the Greenbrier River and at the north end of the valley. The route from Elkins to Durbin was just forty-five miles, about half the distance that the opposing line had to travel from Ronceverte to Durbin. ${ }^{57}$

Publicly, however, he maintained good relations and frequent correspondence with $\mathrm{C} \& \mathrm{O}$ Vice President Decatur Axtell. Even though the C\&O affiliate beat his line into Pocahontas County and covered more territory, and even though other interests had acquired far more prop-

\footnotetext{
${ }^{56}$ Letter to John T. McGraw, April 18, 1900. Series 15 Box 213, H.G. Davis Papers; Letter to John G. Luke. Series 15, Box 214, H.G. Davis Papers.

${ }^{57}$ H.G..D., “Journal,” January 24, 1901; McNeel, The Durbin Route, 17, 18.
} 
erty there than he had, the connection with the $\mathrm{C} \& \mathrm{O}$ still offered the best chance for trade with the south. The Central Railway to Harrisonburg never materialized under Davis' watch. The C\&I and C\&O road through the Greenbrier Valley was already too far along and accomplished the same goal, even if Davis could not exercise as much control over it as he could over a link with the Southern Railway in Harrisonburg. ${ }^{58}$

In August 1903, the Coal and Iron Railway finally reached Durbin and connected with the Greenbrier Railway. The latter traveled almost twice as far and beat the former to the Forks of the Greenbrier River by a year. Nevertheless, H.G. Davis and Stephen B. Elkins finally acquired market access in all directions. Despite the C\&I's tardiness, the line sparked another industrial boom for Randolph County. Within a few years of its completion, logging in eastern Randolph County increased considerably. A web of logging railroads and spurs crisscrossed that part of the county. A second wave of capitalists, many of them from Pennsylvania, bought and cleared thousands more acres of virgin timber. Davis himself sold timber land to the Raine-Andrews Lumber Company, which opened a mill at Gladwin near the Tucker County line and laid track up the Glady Fork. ${ }^{59}$

The tiny community of Glady, at the end of the line, reaped the benefits. Linked to the C\&I by a spur, Glady quickly became a small mountain boom town. It never grew very large by 1910 it contained only 282 residents. Nevertheless, until the Great Depression, Glady boasted many of the industries and amenities of far larger places. As early as 1903, the Glady Lumber Company operated two mills there, and the Lewis Brothers operated two more just north of

\footnotetext{
${ }^{58}$ Letter to D.A. Willey, February 23, 1901. Series 15 Box 214, H.G. Davis Papers.

${ }^{59}$ Steve Bodkins, Bemis and Glady West Virginia: A History of Two Mountain Towns (Parsons, WV: McClain Printing Company, 2006), 24, 25; Letter to T.W. Raine, February 16, 1902. Series 15, 215, H.G. Davis Papers; Clarkson, Tumult On the Mountains, 35; Clarke, 133.
} 
town. In addition to the necessary schools and churches, two more lumber companies opened, along with a hotel, bowling alley, and electric plant. ${ }^{60}$

The Dry Fork Railroad, perhaps even more so than towns such as Glady, demonstrates the precarious nature of success predicated upon extractive industries. For nearly a decade, with the exception of a WCV\&P spur, it alone served the two mills processing the dense forests of eastern Randolph County. But the completion of the C\&I brought new opportunities for existing businesses and entrepreneurs. In 1903, the year the C\&I finally reached Durbin, two additional saw mills opened. Two more mills opened in 1904 and in 1905, with one more opening in 1906 and 1907. While these mills represented more business for the C\&I, they also boosted the business of the Dry Fork Railroad, which remained the only feeder line for those logging camps and mills still beyond the reach of the Coal and Iron -- those in the eastern- and northeastern-most portions of Randolph County and the southeastern-most portions of Tucker County. ${ }^{61}$

The first decade of the twentieth century turned into a boom time for the Dry Fork. The mill at Horton expanded and demand increased steadily. As more mills opened, business grew by leaps and bounds. In 1905, a full decade after its formation, it finally became profitable enough to pay dividends. The good times did not last long. As local historian Don Teter stated, by 1907, "there were no more large tracks of timber available in the Dry Fork region." With timber production effectively peaked, the decline of freight was sure to follow. The Dry Fork's

\footnotetext{
${ }^{60}$ Bodkins, 31-71. See also Don Teter, Going' Up Gandy: A History of the Dry Fork Region of Randolph and Tucker Counties West Virginia (Parsons, WV: McClain Printing Company, 1977). Both works do a fine job covering the various small communities and logging camps that dotted the mountains of eastern Randolph County and southern Tucker County during the early decades of the twentieth century. The books include brief histories of several towns, along with lists of the industries and companies thriving in those regions. They chart the effects, both good and bad, of industrialization.

${ }^{61}$ Don Teter, Going' Up Gandy: A History of the Dry Fork Region of Randolph and Tucker Counties West Virginia (Parsons, WV: McClain Printing Company, 1977), 122. The author provides the names of the various lumber companies that quickly moved into the area after 1903.
} 
business peaked in 1910, and declined rapidly, as deforestation closed down mill after mill. Between 1912 and 1920, five of the nine mills that opened in the previous decade closed. By 1922, just one remained, with most of the Dry Fork Railroad business consisting of passenger service. ${ }^{62}$

Ironically, as fortunes began to improve for some of the smaller players in mountain industrialization, they declined for H.G. Davis. Davis's economic reach extended almost beyond limit and without check. Simultaneously, he served as president of two banks, three railroads, and seven coal companies. ${ }^{63}$ But Davis, Elkins, and all their associates in these various enterprises did not occupy the upper echelons of the Gilded Age business community. Davis and Elkins each served in the United States Senate and both had a national reputation: Elkins as Secretary of War in Benjamin Harrison's administration, and Davis as the 1904 Democratic Vice Presidential nominee. However, both really functioned as regional, rather than national, economic power-brokers. ${ }^{64}$ Despite the regional dominance their business acquired in transportation and coal, and despite the lengthy network of rails they laid in the mountains, their lines ultimately depended on larger railways, whether the $\mathrm{B} \& \mathrm{O}$, the $\mathrm{C} \& \mathrm{O}$, or the Pennsylvania, to carry West Virginia products to market. The very mountains that made Davis and Elkins wealthy and powerful also limited that wealth and power.

${ }^{62}$ Clarke, 133; Teter, 122, 123. The Horton mill was the final mill to close along the Dry Fork, ceasing operations in 1929.

${ }^{63}$ H.G..D., “Journal,” April 10, 1901.

${ }^{64}$ For more on the political careers of both Davis and Elkins, see Ross's biography of Davis. Both men probably wielded more national political than economic clout, or at least thought they did. During the 1888 campaign, Davis, a Democrat, refused to run for West Virginia governor, refused to support party candidates, and did not participate in National Executive Committee proceedings. Davis also firmly believed that Benjamin Harrison owed his 1888 Republican presidential nomination to Elkins. At the Republican nominating convention, Elkins did in fact swing seventy-two delegates into the Harrison camp after friend, business associate, and past and future Secretary of State James G. Blaine refused to run. Interestingly, one of Harrison's rivals for the nomination, Chauncey M. Depew, served as president of the New York Railway Central and Hudson Railroad and director of the Vanderbilt railroad system in New York. On the Davis and Elkins role in the election of 1888, see Ross, 176-222; H.G.D., "Journal," July 3, 1888; Clarke, 107. 
By 1900 the nearly decade-long rift between the $\mathrm{B} \& \mathrm{O}$ and Pennsylvania systems that Davis had exploited to his advantage was resolved. Now the two major lines worked together, and along with the $\mathrm{C} \& \mathrm{O}$, sought total domination of the eastern freight market. This did not mean the WCV\&P would be completely bypassed. It occupied key ground in the mountain counties and served as the link to valuable timber. However, it did mean that Davis's line could be effectively shortened at the northern and southern termini by spurs and extensions of the other lines. Freight and car fee increases also represented other ways in which the WVC\&P might be dependent on the other companies.

Davis's fears were confirmed almost immediately after the B\&O/Penn rapprochement. In January 1900, the Pennsylvania informed the WVC\&P that it must start paying to use the former's railcars. Pennsylvania Railway president A.J. Cassatt informed Davis that free car usage was intended to help the WVC\&P get established. Now that it had, such generosity was no longer necessary. At around the same time, the $\mathrm{B} \& \mathrm{O}$ announced plans to come directly into Ridgeley, a small town in Mineral County down the Potomac from Piedmont and Keyser and immediately across the river from Cumberland. Soon the $\mathrm{B} \& \mathrm{O}$ started charging to use railcars as well. ${ }^{65}$

On some level these simple business measures may have seemed like minor annoyances, and had they occurring independently of other events they would have been innocuous. But these minor moves represented the beginning of a series of maneuvers that soon led to the sale of the West Virginia Central and Pittsburg. While the eastern railroads worked to corner the freight market from the mid-Atlantic to the Ohio Valley, other interests looked to conquer that market for themselves. George Gould, E.L. Fuller, and the Wabash Railroad all wanted to expand eastward.

${ }^{65}$ Clarke, 106-110. 
Through syndicates and agents, which included Joseph Ramsey, president of the Wabash, Gould, the son and heir of railroad giant Jay Gould, bought up land and railroads in western and central West Virginia. The Wabash already extended deep into the Ohio Valley, reaching Pittsburgh through acquisition of smaller roads and infuriating the Pennsylvania Railroad management. Gould intended to weld together every line he could acquire to make one grand transcontinental railroad. Meanwhile, Fuller, an independent anthracite operator and railroad operator in northeastern Pennsylvania and Delaware let Davis know of his willingness to buy the WVC\&P should it ever be for sale. Between 1901 and 1903, all three of these agents worked in various combinations with each other to secure their positions. ${ }^{66}$

Davis and Elkins realized these dealings put their lines, miniscule in comparison, at serious risk. They had played the $\mathrm{B} \& \mathrm{O}$ and Pennsylvania against each other for a time, but no longer. Davis and Elkins knew what could happen. For years the Dry Fork and the Belington and Beaver railroads had served as de facto extensions for their mainline. Now, with new railroad giants entering the region, the WVC\&P could be turned into a de facto extension of one of the big rail conglomerates.

In the fall of 1901, Davis left for Mexico City, where he chaired the American delegation to the Pan-American Conference. During his absence, Elkins handled negotiations with the various parties interested in the fate of the WVC\&P. Fuller still wanted to buy it, but he and Elkins could not agree on a price. Meanwhile, John Davis, H.G.'s son, urged his father and brother-inlaw to form a syndicate of their own for the purpose of building their own lines to the east and west. At some point he swung Elkins to this view, but only temporarily. He believed that no matter whom the WVC\&P sided with, the bigger railroads would eventually abandon the small West Virginia line and "then the West Virginia Central would be even more isolated than at pre${ }^{66}$ Clarke, 112-130. 
sent." After careful long-distance consultation with Davis, the two reached a decision to sell to Fuller. He would purchase the entire WVC\&P mainline and the extensions to Thomas, Beverly, Horton, and Belington. ${ }^{67}$

In November 1901, the WVC\&P Board of Directors issued \$5 million of additional stock. Fuller and his interests purchased this, along with another \$13 million of stock, thus taking control of the company. Davis and his board stayed on for almost another year, overseeing the completion of the Coal and Iron Railroad. In October 1902, he and the board members resigned en masse, and when the Coal and Iron was finally completed in 1903, Davis left his WVC\&P for good. $^{68}$

The Davis empire by no means collapsed. In 1901, when the board issued additional stock, they also voted to surrender controlling interest in the Davis Coal and Coke Company, which the WVC\&P had acquired years earlier. This meant Davis would retain control of his vast coal enterprise, much of which lay untapped in central West Virginia. In 1902, after the sale of the WVC\&P, Davis quickly bought up whatever Roaring Creek coal lands he could, along with two tiny railroads: the Roaring Creek and Charleston and the Roaring Creek and Belington.

These covered a distance of just nineteen miles in western Randolph County and southeastern Barbour County. These seemingly insignificant lines became the foundation for what railroad historian Alan Clarke aptly called “Davis's second railroad empire." Whereas the first empire was built in the mountains on coal and timber, this one, which Davis controlled until his

\footnotetext{
${ }^{67}$ Letters from S.B. Elkins to H.G. Davis November 14, 19, 20, 25, December 2, 1901; Letter from H.G. Davis to George Gould, January 23, 1902; Clarke, 124-127; Ross, 264, 265. Elkins was correct to be suspicious of the major railroads. Fuller was working for Gould, who had been collaborating for years with the Wabash. Soon after Fuller bought the WVC\&P, he transferred it to a syndicate run by Gould. In 1905, the syndicate collapsed and the Western Maryland Railway acquired the WVC\&P and all its extensions. See Clarke, 134 and Ross, 265.

${ }^{68}$ Letter from C.M. Hendley [Davis' secretary] to George D. Woodrow, November 8, 1901. Series 16, Box 239; H.G.D. “Journal," October 23, 1901.
} 
in death 1916, rested entirely on coal and occupied several counties in the Allegheny Plateau in central West Virginia. Using his two new acquisitions as a starting point, Davis built a new railroad south from Elkins through central West Virginia. It reached Charleston in December 1905. After nearly two decades of planning, Davis finally reached Charleston, and now the north central portion of the state was connected to Charleston by rail. ${ }^{69}$

\section{Conclusion}

As Lewis observes, the transformations wrought by the railroad and the extractive industries it spurred had long lasting effects on the mountains. Deforestation wreaked havoc in the highlands, both on the people and the environment. By 1920 the vast virgin forests had disappeared, and the logging industry they supported steadily declined thereafter. Rapid clear-cutting caused devastating fires, as centuries of dried leaves and pine needles, now exposed, created one large tinder-box. A single spark from a fire or passing locomotive could set thousands of acres ablaze. The Blackwater Lumber Company and the Babcock Lumber Company suffered millions of dollars of damages and losses due to fires in Tucker County alone. The West Virginia Pulp and Paper Company experienced similar incidents in Pocahontas and Greenbrier counties, and these were not isolated occurrences. Fires burned up and down the mountains off and on for the first forty years of the twentieth century. ${ }^{70}$

Well before the region experienced the full environmental impact of deforestation and the full economic impact of deindustrialization, however, major changes occurred. The story of the first Davis railroad empire reveals how the process of industrialization both shifted and crossed political allegiances, realizing long-held dreams of development in the Alleghenies. The devel-

\footnotetext{
${ }^{69}$ Alan Clarke, West Virginia's Coal and Coke Railway: A B\&O Predecessor (Lynchburg, VA: TLC Publishing Inc., 2002), 13, 14; H.G..D, “Journal," Newspaper clipping from Elkins paper, December 29, 1905.

${ }^{70}$ Lewis, 7-13, 263-270.
} 
opment faith of which men like Davis and Elkins were apostles signaled the actualization of a power structure that was already a latent reality. Absentee landowners had owned large tracts of land in the region for over a century; technology such as the railroad enabled absentee landowners and their local agents to exercise greater control over the region and maximize the profits from the land. The result was a West Virginia integrated within the larger power structure of industrial America. Again, as the story of the WVC\&P demonstrates, as powerful as men like Davis and Elkins were in West Virginia, eventually they had to base their business decisions on the actions of larger enterprises, such as the Pennsylvania system, the Wabash, and the Gould syndicate.

Unlike other areas of the state, especially the southern tier, organized labor does not comprise much of the story of industrialization in the Allegheny highlands. As Workman observed, "The Elkins field was never especially known for labor militancy."71 Labor occupied a somewhat stronger position in the Potomac field. Miners in Mineral County participated in localized strikes in the 1880s, and also in the larger United Mine Workers' strike in 1894. These events did not please Davis, but while they did result in decreased production, ultimately they proved only a comparatively minor inconvenience. ${ }^{72}$

Likewise, organized labor in timber and railroading appeared similarly passive during the Gilded Age and Progressive Era, although records of its activities are scant. Davis makes no mention of organized labor on his railroads in his diary nor do the annual minutes of the WVC\&P. That does not mean railroad unions did not exist in the mountains. By 1906, all five rail worker brotherhoods operated locals on the West Virginia Central and Pittsburg, with all of

\footnotetext{
${ }^{71}$ Workman, et. al., 103.

${ }^{72}$ Workman, et. al, 77; Annual Report of the WVC\&P (Cumberland, MD: Frank B. Jervey, 1895), 7.
} 
them incorporated into the federation that succeeded the Federation of American Railway Employees. Due to lack of records, it is unclear when the brotherhoods organized in the mountains. However, it is interesting that the brotherhoods did not join the system federation until after the WCV\&P passed out of Davis's and Gould's hands. Davis's second major railway, the Coal and Coke, does not appear to have been unionized during his lifetime. ${ }^{73}$

Davis did, however, at least on the WVC\&P, organize a company relief fund. In what presaged the welfare capitalism of the 1920s, the WVC\&P formed something similar to a company union. All railroad workers, miners, and managers were automatically enrolled in the fund. The company took a small portion of each worker's wages every month. In return, the fund paid out in the event of sickness, injury, or death. Of course, strikes were not covered. ${ }^{74}$

Organized labor made even less impact on the timber industry. West Virginia represented the southern-most extension of the classic lumberjack way of life, albeit in somewhat truncated form due to smaller forest size. Loggers, many of whom came from the great Northern forests, enjoyed considerable freedom of movement, coming and going as they pleased. Family units in camps were rare,unlike in the South. Management did little to arrest this behavior. Rather, they chose to provide the best possible working conditions, the best food, and the highest pay, although for the most part pay, within each job, was uniform. ${ }^{75}$

\footnotetext{
${ }^{73}$ Edwin Clyde Robbins, Railway Conductors: A Study in Organized Labor (New York: Columbia University Press, 1914), 166-169; Paul Michel Taillon, Good, Reliable, While Men: Railroad Brotherhoods, 1877-1917 (Chicago: University of Illinois Press, 2009), 97-102, 156-160. For more on railroad brotherhoods, see Walter F. McCaleb, Brotherhood of Railroad Trainmen (New York: Albert \& Charles Boni, 1936); P. Harvey Middleton, Railways and Organized Labor (Chicago: Railway Business Association, 1941); Joel Siedman, The Brotherhood of Railroad Trainmen: The Internal Political Life of a National Union (New York: John Wiley and Sons, Inc., 1962); Jon R. Huibregtse, American Railroad Labor and the Genesis of the New Deal, 1919-1935 (Gainesville, FL: University of Florida Press, 2010).

${ }^{74}$ Annual Report of the WVC\&P (Baltimore: Wm. J.C. Dulany and Co., 1887), 5, 6.

${ }^{75}$ Lewis, 161; Clarkson, Tumult on the Mountains, 62-64. See also James R. Green, "The Brotherhood of Timber Workers 1910-1913: A Radical Response to Industrial Capitalism in the Southern U.S.A." Past and Present, 60
} 
Despite their relative autonomy, loggers in the camps still chafed under management at times. National unions made little headway in the camps until after World War II, but the lumberjacks did go on strike occasionally. Usually their demands were ignored and they either went back to work or left for another camp. The mills, in contrast, provided somewhat more fertile ground for unions. The International Woodworkers of the World made inroads at Cass in 1900, for example. The Mechanical Workers of America established thirteen groups in Pocahontas County alone by 1911. Management resisted fiercely, and while it never succeeded in completely driving out the unions, it did limit their influence. As in the logging camps, unions exercised little power in the mills until after World War II. ${ }^{76}$

This paucity of labor activity may not allow much of a glimpse of the social and cultural aspects of industrialization, but it permit other issues to come into focus. Appalachian scholar John Hennen looked at capital and labor relations during and after World War I. He argued that the war helped entrench the ideology of the industrial capitalist class "into the consciousness of a culture and thereby transform[ed] ideas into commonly held values that [were] immune to debate in the political arena." 77 West Virginia became "Americanized" with the help of an elite group of economic, educational, and political leaders who bound the state to the national political economy and ensured its role as a producer of fuel and raw materials. The story of industrialization in the mountains during Gilded Age and Progressive Era offers a glimpse at how those connections, both literal and figurative, were formed. Davis and Elkins, along with a host of other absentee land-owners and local elites, brought the existing politico-industrial network into the mountains.

(Aug., 1973) : 161-200; James W. Silver, "The Hardwood Producers Come of Age" The Journal of Southern History 23 (Nov., 1957) : 427-453.

${ }^{76}$ Lewis, 161-163; Clarkson, On Beyond Leatherbark, 144-147.

${ }^{77}$ John C. Hennen, The Americanization of West Virginia: Creating a Modern Industrial State, 1916-1925 (Lexington: University of Kentucky Press, 1996), 3, 4. 
Davis and Elkins and men like them stood at the top of the elite in West Virginia. Their reach extended from the deepest hollow and highest mountain to Capitol Hill and Wall Street.

They too were men under authority, though. In reality, they acted as servants of the development faith, not as its masters. The new order of secular authority they established in the mountains was the same one that triumphed in 1865 . Well before World War I, the flowering of the development faith in West Virginia wed the state to modern industrial America and secured its role as fuel depot and lumber yard of the nation. Contrary to Davis's belief that the extractive industries would propel West Virginia to the forefront of American civilization, however, the national industrial order his railroad helped introduce simply guaranteed that the Mountain State would occupy a decidedly subordinate position within that order. 


\section{4: Methodists}

\section{The Wesleyan Tradition}

The story of Methodist growth in the mountains demonstrates the ability of state and local believers to effectively evangelize the region and to respond to the changes overtaking those counties and the state as a whole. On the national level, Methodists realized the need to bring their missionary apparatus more firmly under control of the national hierarchy. As detailed below, the West Virginia (MEC) and Western Virginia (MECS) conferences recognized the same need. Missions centralization was one of the most important ways in which both annual conferences dealt with industrialization. Methodism already had a foundation in the Alleghenies before 1880, outnumbering both Presbyterians and Baptists combined. However, the railroad opened up more territory, brought more people into the state, and thus created a greater need for missionary activity.

Centralization on a state level was important for missions, but it served to add both complexity and clarity to the religious culture in Appalachia. Because of its "frontier heritage," numerical strength, and religious progeny, Methodism is often held up as representative of the divide which occurred in Appalachian Christianity after 1880. Industrialization coincided with the rise of the holiness movement, which sought to recapture the vitality and purity lost through the church's modernization and institutionalization. Holiness had roots in Baptist churches as well, but Methodism, with its pietistic heritage, constituted the main wellspring of the holiness, and later Pentecostal, movements in the Southern highlands. By contrast, Methodist churches in the larger towns, the county seats, and the emerging urban centers left many of the old ways behind, joining a growing trend in American Methodism toward modernization and institutionalization. Along with holiness churches, whose autonomy allowed them to chart their 
own course, smaller rural Methodist congregations managed to hold on to as much independence as possible, which included continued allegiance to traditional theology. ${ }^{1}$

This portrayal may have indeed been true for some portions of Appalachia during the Gilded Age and Progressive Era. As the twentieth century progressed, it became increasingly true for the region as a whole. The development of Methodism in the Allegheny Mountains of West Virginia suggests this model does not accurately reflect the complexity of the religious culture in the region. Regarding Methodism, the prevailing paradigm for the study of Appalachian religion in general downplays, if not ignores, the significant role of the annual conference, which has been a central part of Methodism since its origins in England. ${ }^{2}$ The dominant school of thought on Appalachian Christianity sees little or no intermediary between local and national bodies. In reality, annual conferences (whose boundaries were not necessarily coterminous with state boundaries) served as important mediators between the circuit/local church and national hierarchies. This is true for all Baptists and Presbyterians as well.

Between 1880 and 1920, significant changes occurred in the MEC and MECS General Conferences. These changes affected local congregations, but the impact was not always, or even primarily, direct and immediate. During this period, circuits and individual Methodist churches had a much closer relationship to the annual conference than they did to the General Conference. The lack of national attention given to missions in West Virginia made this even truer in that state. There, missions and church growth were primarily driven by local and annual conference efforts. The creation of state mission boards, and later district missionary societies, played a large role in Methodism's success in the mountains.

\footnotetext{
${ }^{1}$ Deborah Vansau McCauley, Appalachian Mountain Religion: A History (Chicago: University of Illinois Press, 1995), 241-243.

${ }^{2}$ Richard P. Heitzenrater, Wesley and the People Called Methodists (Nashville: Abingdon Press, 1995$), 152,153$.
} 
To be sure, the concentration of missions in the hands of the annual conferences may have reduced the autonomy and authority of the voluntary societies and the local churches and at the same time strengthened the power of the denominational hierarchy, but such moves by no means took away all decision-making power from local believers. More importantly, the creation of missionary boards was consistent with historic Methodist organization and polity. When West Virginia and Western Virginia annual conferences took control of state missions, they acted according to the connectional principles which had been synonymous with Methodism since the days of John Wesley (specific changes in the annual conferences are discussed in more detail below).

Methodism has always been a connectional faith. Broadly speaking, denominations with an episcopal (bishop) or presbyterian (council of elders) polity could be considered connectional. This stands in contrast to those groups, such as the Baptists, with a congregational (autonomy of local church) form of government. Methodists, however, have a deeper understanding and internalization of the concept. ${ }^{3}$ Throughout Methodist history, the meanings of connectionalism have changed over time, but they have continued to retain common elements. Denominational historian Russell Richey states that the term

designates Methodism's origins; relationships that existed among preachers and peoples and between them and Mr. Wesley; ordained ministerial status and conference membership; conference structures that governed; whatever the actions or measures or processes that held the movement together, i.e. that connected; the evolving movement as institution or polity; a theology or specifically an ecclesiology, often more implicit than explicit; an organizational classification the consequent presumption that Methodism and Methodists would adhere or connect; and therefore a denominational self-understanding. ${ }^{4}$

\footnotetext{
${ }^{3}$ Russell E. Richey, "Connection and Connectionalism," in The Oxford Handbook of Methodist Studies, eds. William J. Abraham and James E. Kirby (New York: Oxford University Press, 2009), 224, 225.

${ }^{4}$ Richey, 211, 212.
} 
In short, the Methodist connection was at once institutional and relational, tangible and conceptual, rational and emotional. In life, Wesley had embodied the idea and the ideal, but neither his death nor the deaths of his immediate successors could break the bonds that early bishops worked hard to create. That was the point of the connection. Richey argues that since the death of Wesley, or at least since the 1816 death of Francis Asbury (Wesley's lieutenant in America and one of the first bishops in the United States, along with Thomas Coke), Methodism has endeavored to institutionalize some of what Wesley did in the way of directing the organizational life of the church. Thus, the creation of various boards at the general and annual conference levels represents the extension of connection and the continued vitality of a foundational principle of Methodism. ${ }^{5}$

The assumption of greater missionary authority by the West Virginia and Western Virginia conferences did constitute a strengthening of the hierarchy, a building of connection from top to bottom, but this connection was among the annual conference, the various districts, and the local churches. To be sure, when the General Conferences devised their new evangelizing schemes, it affected the denomination at all levels. That is a function of the episcopal system of government, but at its core, Methodist connectionalism is about conferencing - Christians being in conversation. The General Conference has greater authority, but the annual conferences are vitally important, as are lesser levels of organization. As Richey observes, "Methodism might be seen as a sequence of such Christian conversations - in class, society, quarterly conference, annual conference, and general conference.” ${ }^{~}$ This ecclesiological

${ }^{5}$ Heitzenrater, 142-147; Richey, 215-217; Hempton, 118, 119.

${ }^{6}$ Richey, 221, 226, 227. 
subsidiarity is what truly separates the Methodist connection from other hierarchical denominations, whether Protestant or Catholic.

Thus, the creation of state mission boards served to extend and enhance the conversation about an issue central to Christianity in general and Methodism in particular. Industrialization sparked new missionary opportunities in the mountains, more opportunities to bring people into Christian conversion. Both the West Virginia and Western Virginia annual conferences played crucial, and in some ways primary, roles in this endeavor. Thus, the role of the annual conference in Appalachian religious life should not be overlooked, as the positions of the MEC and the MEC, South were enhanced in the mountains thanks in large part to these institutions. That West Virginia Methodists deemed more centralization was required to do this should come as little surprise, for their "frontier heritage" notwithstanding, they were a connectional people under episcopal authority. Of the three mainline Protestant denominations studied here, Methodism has the most hierarchical church polity. Early followers of John Wesley recognized his bishop-like authority even while it was still a movement within the Church of England, despite the fact that he was not an ordained bishop in the Anglican Communion and did not have the authority to ordain anyone in the eyes of the church. Nevertheless, as leader of Methodism on both sides of the Atlantic, he did ordain leaders in England, who in turn ordained leaders in America. He appointed Dr. Thomas Coke as the General Superintendent for America, with the authority to elevate Francis Asbury to superintendent as well. ${ }^{7}$

\footnotetext{
${ }^{7}$ James E. Kirby, "Methodist Episcopacy," in The Oxford Handbook of Methodist Studies, eds. William J. Abraham and James E. Kirby (New York: Oxford University Press, 2009), 232, 233. There is historical and historiographical debate about what exactly Wesley did, how he understood it, and what exactly "ordination" in these instances meant, both practically and ecclesiastically. Kirby handles the issues succinctly, although they are of little consequence here.
} 
In 1784, Asbury and Coke adopted the title of "bishop," arguing that term was found more frequently in the Bible when referring to a spiritual overseer and that it meant the same thing as superintendent. Wesley objected, but the American preachers agreed with the reasoning. Thus, the two men officially became in title what they had been in practice: the spiritual leaders of a distinct denomination with an episcopal form of government, the Methodist Episcopal Church in America. Coke eventually returned to England and assumed some of Wesley's authority after his 1791 death, leaving Asbury as the "Superintendent and Bishop of the Methodist Church in America."

Asbury exercised strong episcopal authority, appointing nearly every preacher in America during his time of service and resisting any challenges to his authority while still being accountable to the General Conference. As denominational scholar James Kirby points out, despite Asbury's authoritarian style, he and the conference clearly acknowledged that ultimate power rested with the preachers as they were gathered together in conference. They received it when Asbury himself refused Coke's ordination without the consent of those who would be under his authority. Furthermore, the Christmas Conference (American Methodism's 1784 denominational founding event) mandated that all candidates for ordination be approved by the conference. ${ }^{9}$

Thus, the hierarchical polity is conditioned by the connectional roles and responsibilities of ordained preachers. Even here, the ordained clergy do not preside over a single congregation. The basic building block of Methodism is not the individual congregation, because the

\footnotetext{
${ }^{8}$ Kirby, 232, 237; Karen B. Westerfield Tucker, American Methodist Worship (New York: Oxford University Press, 2001), 258. Coke and Asbury, with the approval of the conference, later appointed other bishops. After Coke's departure, Asbury considered himself the "senior" bishop. However, in 1800 the conference gave legal parity to all the bishops.

${ }^{9}$ Kirby, 233, 234, 237.
} 
connectional idea suggests that the church is "a dynamic community connected by commitment and service."10 Rather, the elemental unit is the charge. Particularly in rural areas the charge is usually a circuit - a group of local churches served by a single minister or elder who travels among them, serving them all and uniting them to each other and to Methodists across the country. Denominational growth gradually necessitated the development of "station" churches (charges consisting of single, stand-alone congregations), usually in more urban areas, but their preachers were still regularly moved to other charges. ${ }^{11}$

The itinerancy, or traveling ministry, was at the heart of the Methodist episcopal system and served as the lifeblood of the connection. All ordained clergy were required to travel throughout the areas over which each served. In addition to directly facilitating the connection, itinerancy allowed for conference oversight of preachers and helped extend the ministry of many uneducated clergy members. ${ }^{12}$ The practice of the itinerancy has changed over time, but still remains an integral part of Methodism in the United States. During the Gilded Age and Progressive Era, when formal education was still not required of ordained ministers, the system served West Virginia and Appalachia well and ensured that even the most remote congregations and circuits had some link to the denomination as a whole.

This is not to say that the connectional system and the episcopate functioned in dictatorial fashion, with every church doing and believing exactly the same thing at the same time. As demonstrated here and in Chapters 7 and 8, Methodists across the country in the late nineteenth and early twentieth centuries displayed a broad unity, but were very willing and able to express

\footnotetext{
${ }^{10}$ Dennis M. Campbell, “Ministry and Itinerancy," in The Oxford Handbook of Methodist Studies, eds. William J. Abraham and James E. Kirby (New York: Oxford University Press, 2009), 275.

${ }^{11}$ Campbell, 275; Westerfield Tucker, 259, 260.

${ }^{12}$ Kirby, 234, Campbell, 274, 275, and Thomas Edward Frank, "Discipline," in The Oxford Handbook of Methodist Studies, eds. William J. Abraham and James E. Kirby (New York: Oxford University Press, 2009), 248; Westerfield Tucker, 258-262.
} 
differences of opinion on matters of orthodoxy and orthopraxy. Some measure of autonomy on the local and state levels was possible and available, but most Methodists who remained loyal to the denomination (either MEC or MECS) into the 1920s (i.e. those who did not leave for holiness groups) did not seem to desire any more independence than that which was inherent in their polity. In fact, as demonstrated below, most Methodists in West Virginia in general and the Allegheny region in particular remained loyal to the denomination during this time.

In her treatment of Methodism in Appalachia, Deborah Vansau McCauley argues that congregations in the mountains leaned towards holiness or became independent holiness churches, while churches in valley towns and larger cities maintained stronger links to mainstream Methodism. In his work on religion in the eastern Kentucky coalfields, Richard Callahan follows this line of thought, echoing the claim that Methodism was not "indigenous" to the region at all by the time of industrialization. Going even further than McCauley, he argues that Methodist churches across eastern Kentucky represented modern religion and society to such an extent that they could not contribute to the emergence of an independent holiness movement. Faced with a choice between mainline religion dominated by secular elites (Methodism) and the dry and doctrinaire Old Time Baptists, many in the working class found holiness appealing and formed their own faith communities. Most of these people came out of the Baptist churches, which numerically predominated prior to industrialization and at least maintained their autonomy in the face of the expansion and consolidation of modernizing forces. ${ }^{13}$ Callahan's findings and

\footnotetext{
${ }^{13}$ Deborah V. McCauley, Appalachian Mountain Religion: A History (Chicago: University of Illinois Press, 1995), 241-243; Melvin E. Dieter, "Wesleyan/Holiness Churches," in Christianity in Appalachia: Profiles in Regional Pluralism, Bill Leonard, ed. (Knoxville: University of Tennessee Press, 1999), 228-237; Richard J. Callahan, Jr., Work and Faith in the Kentucky Coal Fields: Subject to Dust (Indianapolis: Indiana University Press, 2009), 60, 61, 134141.
} 
conclusions fit well in McCauley's larger "mountain church tradition” paradigm (see Chapter 1).

However, he investigates only one small portion of Appalachia.

This investigation here, while obviously also focused on just one small portion of

Appalachia, presents a different picture. As shown in Chapter 6, Baptists in the Alleghenies made

no moves whatsoever in the direction of holiness. Old Time Baptist presence was practically

non-existent. The data indicates that Methodists in the remote parts of the Allegheny highlands,

whether in mountain communities, mill towns, or county seats, exhibited little substantial

displeasure at mainstream Methodism in general or the episcopacy/connectional system in

particular during this period. Shifting into the independent holiness movement by reviving older

Methodist holiness practices and ideas and then moving into Pentecostalism was by no means a

given in industrializing Appalachia. ${ }^{14}$

\footnotetext{
${ }^{14}$ While evidence is almost non-existent, holiness movements in the central Allegheny region seem to stem from German Pietistic roots. It is possible that members of the United Brethren in Christ and the Church of the Brethren (formerly known as German Baptists) formed the first independent holiness (and later Pentecostal) churches in these counties. UBC co-founder Philip William Otterbein, an ordained minister in the German Reformed Church, was heavily influenced by Wesleyan theology and polity. The denomination organized around the conference plan and adopted the Methodist Discipline. Thus, the holiness movements in this part of West Virginia could draw from both the Wesleyan and Reformed wells. The Church of the Brethren traces its roots to Germany and the Anabaptist wing of the Protestant Reformation. The first settlers of this denomination in America came in the early eighteenth century. In the New World they were known variously as Brethren, German Baptists, or Dunkards/Dunkers, until the early twentieth century, when the majority began identifying themselves as the Church of the Brethren. Whatever the precise theological underpinnings of holiness/Pentecostal churches in the mountains, it appears that these independent congregations, which did not really develop until the 1920s at the earliest, were initially indebted primarily to the United Brethren and German Baptists for leadership and membership, not the Methodists. This does not mean that some kind of holiness teaching was not present in the Methodist church in this section of West Virginia. There is no way to tell either way. All the evidence suggests is that the United Brethren and Dunkards took the lead in developing the holiness movement in this part of the mountains. See Deed Book 157, page 166-170. Tucker County Courthouse, Parsons, West Virginia. "Gladwin," Religious Telescope, Sept. 21, 1904; Homer Floyd Fansler, History of Tucker County, West Virginia (Parson, WV: McClain Printing Company, 1962), 482-486; Cleta M. Long, History of Tucker County, West Viriginia (Parsons, WV: McClain Printing Company, 1996), 144-146, 162; Emmert F. Bittinger, Allegheny Passage: Churches and Families, West Marva District, Church of the Brethren, 1752-1990, (Camden, ME: Penobscot Press, 1990), 121, 122, 495-522. For more on the United Brethren in general, see Paul R Fetters, Trials and Triumphs: A History of the Church of the United Brethren in Christ (Huntington, IN: Dept. of Church Services, 1984). For more on the German Baptists and the divisions within them, generally predicated upon differing views on separation from the world, see Bittenger, 1-16 and Martin Grove Brumbaugh, A History of the German Baptist Brethren in Europe and America, reprint (Ithaca, NY: Cornell University Library, 2009). United States Census data indicates that holiness/Pentecostal groups had very few members in West Virginia in the early twentieth century. The Church of God (Cleveland, TN), a Pentecostal denomination, reported 146 adherents in 1916 and 1,226 in 1926. The Church of God (Anderson, IN), a holiness group, had no notable presence in the state in 1916,
} 
However, these West Virginia Methodists should not be equated with those in eastern Kentucky. Callahan's study re-enforces McCauley's assertion that Methodism was the religion of the industrialist in Appalachia. It is portrayed as part of the "colonizing forces" entering the region in the Gilded Age and Progressive Era. The fact that John C.C. Mayo, a leading coal baron in eastern Kentucky and southwestern West Virginia, was an active Methodist supports this presentation of that denomination. ${ }^{15}$ In light of this, it might be easier to understand why miners in eastern Kentucky viewed them with suspicion, why Methodism retained close ties with the culture and worship practices of the urban East, and why the holiness movement gained so little traction within its ranks.

Methodism in the Alleghenies contrasts starkly with Methodism in the Cumberlands. First, as detailed in Chapters 2 and 5, if any denomination best served the interests of the industrialists, it was Presbyterianism. The overwhelming majority of significant capitalists in this part of West Virginia were active in that church, and some local elites actually left the Methodist church and converted to Presbyterianism. Based on available data, there is an exception in the Alleghenies that seems to prove the rule. There was at least one prominent local industrialist heavily involved in the Methodist church.

but had 1,197 members ten years later. By comparison, the Church of Brethren (Conservative Dunkers) reported 3,457 members in 1906, 4,179 in 1916, and 4,956 in 1926. The Old German Baptist Brethren had fewer than 100 members in the early twentieth century; the Brethren Church (Progressive Dunkers) numbered between 500 and 800 during the same span. See Religious Bodies, 1926, Vol.2: Separate Denominations (Washington, D.C.: United States Government Printing Office, 1929), 232, 242, 245, 361, 365.

In short, the primary difference between holiness and Pentecostal groups involved gifts of the Holy Spirit such as speaking in tongues and faith healing. Pentecostals such as the Church of God (Cleveland, TN) believe in, practice, and seek these gifts as normative religious practices. Holiness denominations such as the Church of God (Anderson, IN) focus on growing in holiness, arguing that entire sanctification is possible and is a distinct work of the Holy Spirit. Manifestations of the Spirit's power such as glossolalia are not denied, but are not seen as part of normative practice. For more on holiness and Pentecostal groups, see, among others, Samuel S. Hill, One Name but Several Faces: Variety in Popular Christian Denominations in Southern History (Athens, GA: The University of Georgia Press, 1996), 79-105 and Stanley M. Burgess and Eduard M. van der Maas, eds. The New International Dictionary of Pentecostal and Charismatic Movements (Grand Rapids: Zondervan, 2002).

${ }^{15}$ McCauley, 239-241; Callahan, 60, 61. 
In 1903, H.C. Newbury and J.H. Babb, owners of the Tygart River Lumber Company, came to Mill Creek, in Randolph County, West Virginia. Newbury had been a member of the MEC in Davis, WV. He, Babb (whose previous church affiliation cannot be determined), and other former members of the Davis church founded an MEC church, the only other fellowship in town being MEC, South. This church became part of the existing Beverly charge. In addition to Babb and Newbury, other founding trustees included a farmer, a dry goods merchant, and the postmaster. Unfortunately, no other records for either Mill Creek church remain. ${ }^{16}$

The second major contrast deals with the very presence of that church in the two regions. As shown in Chapter 2 and here below, Methodists predominated in the mountains of West Virginia, both before and after the coming of the railroad and the growth of extractive enterprises. Methodism did not come in on the railroad; even in Mill Creek it already existed in some form. It was already well-entrenched in communities of all sizes. Even after big business transformed the region, people of all social classes remained active in the church and occupied leadership positions.

It is impossible to determine the extent to which holiness teachings influenced or reinfluenced Methodists in the Alleghenies. However, when compared to the situation in the Cumberlands, it seems that the conditions which encouraged the rise of independent holiness churches did not exist in this particular part of West Virginia through most of the Gilded Age and

\footnotetext{
${ }^{16}$ Pearle G. Mott, History of Methodism in Davis, West Virginia: 1885-1964 (s.1.: s.n., 1965), 19; "History of the Mill Creek United Methodist Church," (s.l.: s.n., 1965), 1; Twelfth Census of the United States, 1900; Thirteenth Census of the United States, 1910. There are fragmentary records from Valley Chapel, a MECS congregation located several miles south of Mill Creek which erected its own meeting place in 1909. Not surprisingly, most members were farmers, with a few being laborers. The first group of trustees included three farmers and a laborer. See "A Short, Incomplete History of Valley Chapel Church," (Beverly, WV: Self-Published Congregational History, n.d.), 1-5. The examination of various churches below shows that both MEC and MEC, South attracted people of all social classes. Neither could properly be called the church of the industrialist or the church of the upper class, although, as is evinced below, upper and middle class West Virginians did join the both branches. While the MEC church was new in Mill Creek, it was not foreign to central/southern Randolph County. Thus, it is not really an example of "railroad religion."
} 
Progressive Era. Those churches that could have been prone to holiness remained within mainstream Protestantism. At the same time, the polity of mainstream Methodism allowed for the cultural and social diversity of members across the country. The connectional system encouraged, and in some ways required, local participation in worship and church life, which would in turn shape local congregations and charges in different ways.

Methodist scholar Karen Westerfield Tucker argues that one of the most important roles of the ordained clergy (bishops, elders, and deacons) was to "intentionally build up and encourage the laity" to "more active participation and leadership in worship." $" 17$ All lay members were expected to engage fully in the life of the church. Beyond this, the Discipline described specific ministerial roles that lay people could fill, such as local preacher, exhorter, and deaconess. The examination of churches and charges in this part of West Virginia shows that local preacher and exhorter were very much in use in the late nineteenth and early twentieth centuries; deaconesses do not appear in any church records from this region at this time. Furthermore, people of all social classes could serve in these capacities. ${ }^{18}$

Methodists took lay ministry very seriously. A divine calling was as much a requirement for lay ministry as it was for ordained ministry. The district conference, which was the ecclesial unit just below the annual conference, licensed lay preachers on the recommendation of the quarterly conference (the meetings of the various churches in a given charge held four times per year). Quarterly conference approval came after the candidate passed an examination on

\footnotetext{
${ }^{17}$ Westerfield Tucker, 262.

${ }^{18}$ Westerfield Tucker, 264-269.
} 
"doctrine and discipline." ${ }^{19}$ In the absence of a deacon or elder, a local preacher could exercise almost as much authority as ordained clergy.

As the title suggests, the primary purpose of the local preachers was to preach. Bringing a message from God to the people was very important, but it was not the only task to perform. The reliance on non-ordained ministers quickly raised questions about what else they could do. They could preach, calling people to repentance and to church membership. True conversion necessitated baptism, and that was a sacramental function that only ordained clergy could perform. By the early twentieth century, the MEC finally allowed lay preachers to preside at marriages where allowed by law. In 1906, the MEC, South permitted non-ordained ministers to baptize; the MEC followed suit in 1912. Lay preachers in both denominations still lacked the authority to administer the Lord's Supper. ${ }^{20}$

The exhorter, upon recommendation from the local church, received a license from the quarterly conference "to hold meetings for prayer and exhortation." ${ }^{21}$ While not possessing much official ecclesiastical authority, the exhorter nevertheless played a crucial role in Methodist life at the grassroots level. He or she bore some of the responsibility for ensuring the Methodists would live up to their calling as Christians and as Methodists - to be holy. That was the primary focus of exhortation. Prayer became a conduit between God and the individual and the group as a whole. God worked with the particular parishioner and the group as a whole to help them all

\footnotetext{
${ }^{19}$ The Doctrines and Discipline of the Methodist Episcopal Church, South (Nashville: Publishing House M.E. Church, South, 1910), 88-93. A local preacher became eligible to become deacon after four years of service, with the recommendation of the district conference.

${ }^{20}$ Westerfield Tucker, 266, 267. In 1926, Southern Methodists granted local preachers the power to administer the Lord's Supper and this practice continued after the merger with the MEC and Methodist Protestants in 1939, although neither of these two groups had similar ecclesiastical provisions. In 1948, the General Conference revoked the authority, only to reinstate it in 1952. Baptism and marriage remained permissible, with approval by the bishop.

${ }^{21}$ The Doctrines and Discipline of the Methodist Episcopal Church, South, 96-98.
} 
increase in holiness, both personal and social. Exhorters also played vital roles at camp meetings and revivals, helping to prepare people for the experience.

As the study of Methodism below indicates, lay ministry not only constituted an important part of church life, it also acted as a fulcrum, balancing hierarchical polity with egalitarian theology. Lay service cut across gender and class barriers, demonstrating that popular religiosity could exist, even thrive, under a highly organized and coordinated episcopal system. The commitment that West Virginia Methodists showed towards denominational structures at the state and national levels did not mean they sacrificed key manifestations of popular religion inherent within the Wesleyan tradition. Commitment to popular religion remained very high through the Progressive Era.

In the following pages, a discussion of Methodism at all denominational levels highlights some of the pertinent developments taking place in the denomination between 1880 and 1920 . The coverage of the annual conferences and districts, charges, and congregations reveals that adherents across the state were well aware of what was occurring within their church and that what was happening within West Virginia Methodism was consistent with these national changes. In short, they were well connected. At the same time, mountain believers appealed to the egalitarian aspects of their heritage to adjust to the industrial and transportation revolutions taking place around them. Through 1920 at least, they managed to remain loyal to the denomination while still providing meaningful ways for people from all segments of society to exercise some authority in the local church and to express their faith and be influenced by it.

\section{The General Conferences}

Unlike the Baptists, who virtually started from the ground up in the Alleghenies, the Methodists were already prevalent throughout the region at the beginning of industrialization. 
They were the largest denomination in the mountains, and in West Virginia as a whole. To some degree, this fact influenced how the various Methodist branches viewed the area as a mission field. At the same time, it was hard to ignore the advance of the railroad and the rapid influx of people. While there were differences between the two major groups of Methodists, during the last quarter of the nineteenth century they all continued to adhere to traditional Wesleyan understandings of Christianity.

Furthermore, their approaches to missionary work were similar. At the national denominational levels, this theological unity would start to fracture in the first decades of the twentieth century. At the annual conference level, however, Methodists of all stripes in the mountains, and in West Virginia in general, remained loyal to the older understandings of the faith (see Chapters 7 and 8 for more on this subject). A popular religiosity grounded in an egalitarian theology prevailed, along with a healthy devotion to traditional denominational structures. Mountain Methodists in West Virginia worked within the episcopal structure of the church to preserve their worship practices and doctrinal positions.

Methodism's denominational structure provides an excellent opportunity to explore the nature of Appalachian religion. Studying the Allegheny region of West Virginia is particularly helpful due to the fact that the churches in the various counties fell under the jurisdiction of different annual conferences during the last quarter of the nineteenth century. This situation changed early in the following century. Nevertheless, the basic workings of church organization remained the same and continued to demonstrate both popular religion in West Virginia and the strong religious connections between the mountains and the rest of the country that preceded industrialization. 
At the dawn of the industrial era, most Methodist churches in the mountain counties of West Virginia belonged to one of the two sectional branches of the denomination - the Methodist Episcopal Church (MEC) or the Methodist Episcopal Church, South (MECS or Southern Methodist). ${ }^{22}$ Southern Methodist churches in the region belonged to one of two conferences. Those in Mineral, Grant, and Pocahontas were in the Baltimore Conference; Randolph and Tucker churches were in the Western Virginia Conference. Methodist Episcopal churches were split among three conferences. The Baltimore Conference encompassed Mineral and Grant counties. Churches in Tucker and Randolph counties were members of the West Virginia Conference. Those in Pocahontas belonged to the Virginia Conference. ${ }^{23}$

The sectional tension which spurred the division in Methodism also effectively blocked cross-regional missionary endeavors. The split was amicable, but boundaries were drawn. Often, as in the case of West Virginia, those were unclear and somewhat porous. For the most part, the MEC and the MEC, South concentrated their efforts in the North and South respectively. The Union victory in the Civil War, while not healing the religious divide, did seem to embolden both groups to embark on more ambitious missionary endeavors.

In some ways, the MECS had the more daunting task. The fall of the Confederacy called into question the legitimacy of a Southern wing of Methodism, even among many Southern Methodists. In 1866, the General Conference took up the task of ensuring the denomination could thrive in radically different social and political situations. The conference initiated several

\footnotetext{
${ }^{22}$ There were a notable number of Methodist Protestant churches in the mountains as well, all of which belonged to the West Virginia Conference of that denomination. Unfortunately, records for those are so scant that it is not feasible to include that group of Methodists in this study.

${ }^{23}$ For more on Methodist denominational structure and the history of the development and growth of these branches of Methodism and conferences in the state of West Virginia, see Chapter 1.
} 
changes that year, including giving the laity some representation in General Conference meetings. Lay delegates first took their seats in $1870 .^{24}$

Democratization coincided with missions restructuring. Previously, the missionary society overseeing Southern Methodist missions was "authorized but not governed by the church." The General Conference selected the mission board's executive secretary and a treasurer, but the board overseeing society functions was independently chosen. The new model created two boards, the Foreign Mission Board and the Domestic Mission Board, both under the auspices of the General Conference. The national body consolidated these into a single mission board in $1870 .^{25}$

Greater centralization at the national level did little to infringe upon the autonomy or the responsibilities of the various annual conferences. Ninety percent of money collected for missions remained with the annual conferences. But the Southern General Conference, armed with a new missions structure, undertook important evangelistic labors. Unlike the MEC, which made notable incursions into the South, the MECS did not attempt to move north.

It did move quickly to reclaim lost black members from the MEC, the African Methodist Episcopal Church, and the African Methodist Episcopal Zion Church. By 1869, black membership in the MECS had plummeted to less than 20,000. Southern Methodists worked with blacks, many of them former slaves, to build a fully independent church, the Colored Methodist

\footnotetext{
${ }^{24}$ Russell E. Richey, Kenneth E. Rowe, and Jean Miller Schmidt, The Methodist Experience in America, A History, Vol. 1 (Nashville: Abingdon Press, 2010), 226. Laywomen were not seated as delegates to the MEC, South General Conference until 1922. See Richey, et. al., 282, 283.

${ }^{25}$ Robert W. Sledge, "Five Dollars and Myself": The History of Mission of the Methodist Episcopal Church, South, 1845-1939 (New York: General Board of Global Ministries, The United Methodist Church, 2005), 115-119; 143, 144. The General Conference effected further consolidation in the early years of the twentieth century and again reorganized it the 1920s. The specifics of each re-organization are not as important to this study as is the simple fact the denomination quickly consolidated missionary efforts under the national hierarchy. See Sledge, 304-309; 343347.
} 
Episcopal Church (now known as the Christian MEC), in 1870. Its bishops were ordained by Southern Methodist bishops, thus connecting the CME to the Christmas Conference of 1784, which established American Methodism. Despite formal ecclesiastical independence, Southern Methodists continued to view their relationship to the CME in paternalistic terms. As late as 1910, white bishops argued that "no church has been better" to freedmen in general as the MECS. In addition to black evangelization, Southern Methodists also undertook work among Indians, Chinese, and European immigrants, particularly the Germans. ${ }^{26}$

Among all of these minority groups, the General Conference seemed to account for the entirety of the Old South and the Southwest. In 1894, it added city missions to that list, but women's missionary societies already had a presence in the urban New South. However, there was still one group which the General Conference continued to overlook: mountain whites. Border and upper South states such as West Virginia, Kentucky, Missouri, North Carolina, Tennessee, and Virginia experienced so called "altar-against-altar" situations. Both MEC and MECS annual conferences occupied the same territory at the same time. The MEC usually treated these areas as mission territories, establishing rival conferences after the war in mountain regions of those states that had little or no MEC presence. Southern Methodists, on the other hand, viewed those states as home. They defended them as rightfully theirs, but they did not see the need to go on the offensive. ${ }^{27}$

\footnotetext{
${ }^{26}$ Sledge, 125-133; 140-143, 145; Frederick A. Norwood, The Story of American Methodism (Nashville: Abingdon, 1974), 332, 333; "Bishops' Address," Journal of the General Conference of the Methodist Episcopal Church, South, 1910, 18. Denominational historian Robert Sledge argues that the defections of congregations in southern Illinois to the MECS did not result from General Conference actions. Rather, they represented "the final shaking out of the boundary issues from 1845." These congregations had never been completely satisfied in the MEC and decided on their own to unite with the Southern wing. See Sledge, 145, 148-153.

${ }^{27}$ Sledge, 145-147; 215. See also John Patrick McDowell, The Social Gospel in the South: The Women's Home Mission Movement in the Methodist Episcopal Church, South, 1886-1939 (Baton Rouge: Louisiana State University Press, 1982); Jean Miller Schmidt, Grace Sufficient: A History of Women in American Methodism, 1760-1939
} 
The MEC, South General Conference left mountain work to the annual conferences until the early twentieth century. For their part, annual conferences established "domestic" mission boards, responsible for a variety of weaker congregations. Thus, work in Appalachia varied widely and was often an extension of more localized evangelism. In 1906, the General Conference finally declared the area between Birmingham, Alabama, and Wheeling, West Virginia, a mission territory. It saw that vast swath of territory as "backward, isolated, and impoverished." Despite the recognition of need and the supposed moral degeneracy of Appalachians, the General Conference took little additional action before 1920. Some annual conferences contributed to the effort, and women's organizations received more support, but mountain work continued to be relatively neglected by the denominational hierarchy through the Progressive Era. ${ }^{28}$

Invigorated by Union victory, the Methodist Episcopal Church viewed the post-war period with optimism. A democratic impulse surged through that branch as well. As was the case in the South, the movement for lay representation at the General Conference began before the war. A well-organized lay campaign prodded the hierarchy into examining the issue, but the debate on slavery took precedence. Secession and war soon followed, and the issue was tabled again. The General Conference proceeded slowly, finally calling for a denomination-wide referendum on the subject in 1868 . The clergy voted overwhelmingly in favor of lay representation, and the laity, both men and women, approved the referendum as well. In 1872,

(Nashville: Abingdon Press, 1999); and Wendy J. Deichmann Edwards and Carolyn De Swarte Gifford, eds., Gender and the Social Gospel (Chicago: University of Illinois Press, 2003).

${ }^{28}$ Sledge, 215, 333. For more on Southern Methodist missions, see James Cannon III, History of Southern Methodist Missions (Nashville: Cokesbury Press, 1926). By 1926, the Board of Missions funded 24 missionaries working in West Virginia, many of whom were appointed after 1920. Most served the southern coalfields, with some also laboring in the northern tier. There is no record of any in the mountain counties at this time. See Cannon, 292-301. 
laymen, and lay men only, were seated at the General Conference behind the clergy (although not yet in equal numbers). ${ }^{29}$

The General Conference of the Methodist Episcopal Church also engaged in more comprehensive, although similar, missionary activity than its Southern counterpart. It had been working to centralize missionary activity since the schism. The MEC Missionary Society, in charge of both domestic and foreign missions, traditionally had been independent, and the annual conferences labored as they saw fit. In 1844, the General Conference created a General Missionary Committee to coordinate with the Missionary Society and make its efforts more responsible to and representative of the entire church. Centralization continued after the war when, in 1868, the General Conference began writing the rules and regulations for the missionary society. Four years later, the General Conference began electing the Board of Managers of the Missionary Society, along with those of the benevolent societies. As denominational scholar Wade Barclay observed, concentration made "the total missionary program a concern of the entire Church."30

As with the Southern Methodists, MEC centralization did not significantly strip annual conferences of missionary power or responsibility. The annual conferences, regional para-church organizations, and local churches were now held more accountable to the General Conference, but re-organization within the MEC primarily resulted in greater efficiency and productivity

${ }^{29}$ Richey, et. al., 228, 229. The issue of laywomen attending the conference did not go away. In 1888, five annual conferences elected women as delegates to the General Conference, one of whom was Women's Christian Temperance Union leader Frances Willard. After a fierce debate and vote, the women were not seated. The male clergy and laity decided that the term "laymen" in the Book of Discipline (the codification of Methodist polity and teaching) must be interpreted literally to mean lay men. In fact, the clergy voted decidedly against women's representation, whereas the laity actually favored that cause by two votes, but that did not end the matter. Annual conferences continued to send women to the national meeting. Finally, in 1900, after an adoption of a new constitution, women were permitted to serve as delegates to the General Conference. They first took their seats in 1904. See Richey, et. al, 278-282.

\footnotetext{
${ }^{30}$ Wade Crawford Barclay, The Methodist Episcopal Church, 1845-1939, Vol. 3: Widening Horizons, 1845-1895 (New York: The Board of Missions of the Methodist Church, 1957), 116-119.
} 
throughout the denomination. Coordination under the auspices of the hierarchy meant maximizing financial and human resources, not only for foreign and domestic missions, but also for education, health care, and other benevolent projects. ${ }^{31}$

At the same time, urban and minority missions also became a priority. With rapidly increasing immigration, these were often one and the same. In 1864, the General Conference officially recognized the need for city evangelization, a task several annual conferences had already taken up. Existing ministries remained in place, but now the Bishops also had the power to appoint "missionaries to neglected portions of our cities." ${ }^{, 32}$ Domestic mission efforts also expanded in the West and the South. Existing work among the Native Americans and in Oregon and California was re-organized, with a new emphasis on evangelizing Asian immigrants. The General Conference also planned projects for Utah, Idaho, and Montana. ${ }^{33}$

The postbellum mission to the South was two-fold - to minister to former slaves and reach out to whites, some of whom may have been Union sympathizers. After the war, the MEC, in violation of the 1844 plan of separation, embarked on an extensive campaign in the Old Confederacy. In 1866, a group of Methodists formed the Freedmen's Aid Society. The General Conference approved the body in 1868, and in 1872 it became an "official arm of the church."34 The new society cooperated with the other Methodist societies to bring the gospel to former slaves and to teach them the skills necessary to prosper as free people. As such, education

\footnotetext{
${ }^{31}$ Russell, et. al, 232, 233.

${ }^{32}$ Barclay, 222.

${ }^{33}$ Norwood, 333; Barclay, 227-299.

${ }^{34}$ Norwood, 272.
} 
constituted an important part of the work among Southern blacks. By 1867, it had established schools in Kentucky, West Virginia, and seven former Confederate states. ${ }^{35}$

The Methodist Episcopal Church was already in the process of establishing annual conferences in the South that would serve both whites and blacks. By 1870, it had checkered the South with these mission conferences, with many of the clergy coming down from the North. In the Deep South, blacks comprised most of the membership, as white Methodists remained loyal to the MEC, South. In the upper South and border states, however, whites sympathetic to the Union cooperated with Northern missionaries. ${ }^{36}$

In many ways, these missionary conferences were extensions of antebellum efforts to retain border congregations. Since the 1850s, support to border conferences in West Virginia, Kentucky, and Missouri had increased. Conferences in Tennessee, North Carolina, and Virginia, however, had sided with the South, and so Union sympathizers, many of whom lived in the mountain regions of these states, were not properly connected to or communing with the MEC. Even before the war ended, 120 Methodists in eastern Tennessee, half of whom were clergy, expressed their desire to unite with the MEC. An MEC bishop and six ministers organized the Holston Conference in 1865, which at the time spanned parts of eastern Tennessee, western North Carolina, and southwestern Virginia. ${ }^{37}$

This could be regarded as the beginning of MEC mountain work. However, once the Holston Conference was organized, the national body left it to function as any other annual

\footnotetext{
${ }^{35}$ Barclay, 332. Despite their willingness to aid Southern blacks, white members of the MEC were not immune to the racial tensions and pressures of their day. Immediately after the war, separate annual conferences were established for blacks. By 1895, as the South erected the edifice of Jim Crow, there were no racially mixed conferences in the MEC. See Norwood, 272.

${ }^{36}$ Barclay, 303 .

${ }^{37}$ Barclay, 304, 305. This new Holston Conference actually mirrored an existing Southern Methodist conference occupying the same territory. The MEC, South Holston Conference also included parts of southern West Virginia.
} 
conference. Through Reconstruction, the MEC work in the South primarily focused on race relations in the various missionary conferences. With the blacks being comparatively scarce in the up-country, these regions remained neglected. That changed in the 1880 s, as Northern Protestants in general began to see the need for specific work among mountain whites.

In the case of the MEC, this would in some way replicate the work already being done among former slaves. The church hierarchy came to see Appalachians as a distinct people in need of spiritual and social uplift. Thus, in addition to sending missionaries, the denomination also built schools throughout the mountains. Much of the work was done in coordination with annual conferences and local church and non-sectarian voluntary societies. As was the case in the MEC, South, women occupied an important role, especially in the settlement house movement, which began to spread to rural Appalachia in the late nineteenth century. ${ }^{38}$ This early attention t0 the Southern Mountains did not include West Virginia. Neither national body established notable mission work in the Mountain State through the first two decades of the twentieth century, despite the advent of the railroad and rapid industrialization. The state did play host to opposing annual conferences, but those pre-dated the war and were well established. The MEC church predominated, but the Southern church also claimed a sizeable number of adherents. By 1880, the MEC, the largest Protestant denomination in the state, registered 30,892 full members. The MEC, South had 14,681 full members, making it the third largest Protestant group, just behind Northern Baptists. ${ }^{39}$

\footnotetext{
38“"Bishop's Address," Journal of the General Conference of the Methodist Episcopal Church, 1884, 7. See also David E. Whisnant, All That Is Native and Fine: The Politics of Culture in an American Region (Chapel Hill: The University of North Carolina Press, 1983), 19-34. One of the best examples of a rural settlement house in West Virginia is the Scott's Run Settlement House, established in 1922 by women from Wesley Methodist Episcopal Church in Morgantown, West Virginia.

39"'Statistical Table," Official Journal of the West Virginia Conference, Methodist Episcopal Church, 1880, 68; "Statistical Report," Western Virginia Conference Journal, Methodist Episcopal Church, South, 1880, 37. These numbers reflect only the Western Virginia Conference and the West Virginia Conference. Parts of West Virginia,
} 
While the MEC had more than double their membership, Southern Methodists could be found in every part of the state, including the mountain counties with large populations of Union sympathizers. Each branch of Methodism saw the entire state as open territory, unlike the Presbyterians, who divided the state between the two major branches. Both sides scrambled to open up new churches as the railroads opened up new territories.

\section{The Annual Conferences: Missions and Boundaries}

The state annual conferences, however, saw an ideal opportunity to evangelize an increasing population and strengthen the position of their respective churches. State and local mission movements thrived, often with indirect support at best from the General Conference. Local congregations were expected to contribute to and support missions in their parts of the state, but state bodies ensured that the various districts had ample financial resources. ${ }^{40}$ The Western Virginia and West Virginia conferences followed the leads of the respective General Conferences by centralizing mission work over the second half of the nineteenth century. Both annual conferences established missionary societies before the war, each responsible for both foreign and domestic labors.

The Missionary Society of the West Virginia Conference was an autonomous organization, cooperating with the state hierarchy but not subject to its authority. Not until later did the state body, through the General Mission Committee, take control of the society by

including some of the mountain counties studied here, belonged to the Baltimore or Virginia conferences. Churches in these counties were often grouped with churches in other states, so the exact number of Methodists, both Northern and Southern, in West Virginia before 1900 is difficult to calculate. Nevertheless, the numbers from the Western Virginia and West Virginia conferences sufficiently illustrate Methodism's numerical superiority in the state and the relative strength of each branch.

40“"Committee on Missions," Official Journal of the West Virginia Conference, Methodist Episcopal Church, 1884, 17; “District Reports,” Western Virginia Conference Journal, Methodist Episcopal Church, South, 1885, 43, 44. Annual conferences were divided into districts, the boundaries of which usually corresponded to county borders. Districts usually covered several counties. Districts were divided into charges. Charges with at least two churches were called circuits and a single pastor served each congregation therein. A church not on a circuit was called a station church. Those were usually found in cities and larger towns. 
appointing its Board of Managers. Missionary conventions convened in each district beginning in the 1896. Southern Methodists also had a missionary wing, but it had been under the direct auspices of the annual convention since its inception. This started as a Committee on Missions, but by 1867 constitutional changes allowed for the creation of a Missionary Board. ${ }^{41}$

At the dawn of the industrial age, West Virginia Methodists were divided among five annual conferences - two in the MEC, South and three in the MEC. However, the Western Virginia Conference and the West Virginia Conference conducted the majority of missionary endeavors within the state. The entire eastern panhandle belonged to a different jurisdiction in both branches, but the two state bodies wanted responsibility for it and did what they could to ensure the evangelization of the region, at least the western, more mountainous parts of it. In 1878, for example, the West Virginia Conference petitioned the General Conference to reconfigure the boundaries of the annual conference to include the entire state of West Virginia, as well as the western part of Garrett County, Maryland. In 1880, the Keyser church, located in Mineral County, notified the General Conference of its desire to remain in the Baltimore Conference and requested that the national body not alter the boundaries. That annual conference in turn instructed its delegates to the General Conference to oppose any and all efforts at changing boundaries. They asserted "that the interests of the Church in those charges are better secured in connection with the Baltimore Conference, and that removal to the West Virginia Conference would be injurious to the charges and the conference." 42

\footnotetext{
${ }^{41}$ Carl E. Burrows, Robert B. Florian, David F. Mahoney, Melting Times: A History of West Virginia United Methodism (Charleston, WV: Commission on Archives and History, West Virginia Conference, United Methodist Church, 1984), 135, 136, 211, 212.

42،"Home Mission Report," Official Journal of the West Virginia Conference, Methodist Episcopal Church, 1878, 58; "History of First Methodist Church," (Keyser, WV: Self-Published Congregational History, n.d), 2. "Protest Against Removal of any Portion of Baltimore Conference Territory," Minutes of the Baltimore Conference of the Methodist Episcopal Church (Baltimore: Methodist Episcopal Book Rooms, 1880), 22. Technically, the counties of the eastern panhandle never did become part of the West Virginia Conference, MEC. Those counties, with the exception of the
} 
The West Virginia Central and Pittsburg Railway helped aggravate this border dispute between the West Virginia Conference and the Baltimore Conference. The railroad began in Mineral County and proceeded southwest through Grant County. Both of those counties fell under the jurisdiction of the Baltimore Conference. The WVC\&P then entered the West Virginia Conference, running through Tucker and Randolph counties. Methodists in both wings of the denominations used the railroad to support existing churches and plant new ones. Mission work in Tucker County, which will be discussed below, led naturally to efforts in Grant and Mineral counties to the North. The mountainous portion of western Grant County had no real Methodist presence. Methodism had some hold in Mineral County along the railroad, but most of its strength was in the northern and central parts of the county, closer to Hampshire County, from which it was severed (see Chapter 2).

The West Virginia Conference demonstrated great willingness to support evangelistic efforts outside its territory. The gospel knew no boundaries. By the 1890s, two churches Bayard and Gormania, located within the bounds of the Baltimore Conference - had been established directly along the mainline in Grant County, with a third founded about ten miles east in Mt. Storm. A fourth congregation had been formed in Blaine, just over the Mineral County line. ${ }^{43}$ Throughout the second half of the decade, the Bayard congregation held a revival every year. Each lasted at least a month and included two services every day. Its protracted meeting in 1896 yielded ninety-six converts. Two years later, in an event the Grant County Press described as "the greatest revival ever held in Bayard, and doubtless in in this county," 116 people

eastern-most counties of Jefferson, Berkeley, and Morgan, joined the West Virginia Annual Conference of the Methodist Church in 1939 as a result of the nationwide merger of the Methodist Episcopal Church, the Methodist Episcopal Church, South, and the Methodist Protestant Church. See Burrows, et al., Melting Times, 357-361; 398.

43،"Historical Record: Mt. Storm United Methodist Church,” Mt. Storm United Methodist Church, (Mt. Storm, WV: n.d.), n.p; "Gormania Charge," Mt. Storm United Methodist Church, (Mt. Storm, WV: n.d.), n.p. 
converted, eighty-five of whom joined the church. These meetings appeared to continue well into the twentieth century. ${ }^{44}$

Additional records are scarce, even in denominational sources. The West Virginia Conference included them all in the Blaine Charge, which consisted of churches in western Garrett County, Maryland, rightfully under its authority. In 1903, the annual conference, again technically acting outside its jurisdiction, put the three Grant County churches on their own charge. It also requested that the General Conference transfer Mineral and Grant counties into West Virginia Conference jurisdiction. The Baltimore Conference, which appeared to count the churches on its records, objected and no action was taken. ${ }^{45}$

Two years later the West Virginia Conference took up the issue again. It appointed a committee to meet with representatives from the Baltimore Conference. The latter refused a meeting, instructed the Presiding Elder of the Frederick District to take steps to care for the churches under his supervision, and requested that the West Virginia Conference stop appointing pastors to the charges under dispute, something that body had been doing for a decade. ${ }^{46}$

A meeting final occurred in 1906. The West Virginia Conference conceded that it had no ecclesiastical authority over northwestern Grant County. However, the Baltimore Conference admitted it had neglected the area. Had it not been for the work of West Virginia Methodists, there would be no churches over which to quarrel. The congregations preferred to be in connection with West Virginia, and Baltimore realized it would not help ministry work in that

\footnotetext{
44،"Bayard Letter," Grant County Press (Petersburg, WV), Dec. 4, 1896; "Bayard Letter,” Dec. 17, 1897; "Big Revival," Dec. 11, 1898; "Bayard," March 2, 1917.

45"Report of Committee on West Virginia Conference," Minutes of the Baltimore Annual Conference of the Methodist Episcopal Church, 1905, 39.

46،"Report of Committee on West Virginia Conference," 39; "Concerning Boundary Dispute," Official Journal of the West Virginia Conference, Methodist Episcopal Church, 1905, 72, 73.
} 
area if it forced those churches to remain under its control. Thus, the Baltimore Conference agreed to formally transfer three churches in Grant County and two churches in eastern Garrett County, Maryland, to the West Virginia Conference. ${ }^{47}$ That same year, the West Virginia Conference acquired the West Virginia section of the Greenbrier District from the Virginia Conference, which had disbanded. This included Monroe, Greenbrier, Pocahontas, and Pendleton counties. ${ }^{48}$

Southern Methodists experienced some border controversy as well. In the early twentieth century the General Conference considered giving the Western Virginia Conference the Lewisburg District of the Baltimore Conference. That district included Pocahontas and Greenbrier counties of West Virginia and some of the Shenandoah Valley counties of Virginia. In 1910, the Baltimore Conference of the MECS memorialized the General Conference against the boundary change and the matter soon dropped. ${ }^{49}$ The Western Virginia Conference acquired no new territory between 1880 and 1920. However, that did not mean the annual conference boundaries completely satisfied the West Virginia Southern Methodists. Calls to acquire territory from the MECS's Holston Conference began in the early twentieth century. They culminated in 1914, when the General Conference investigated the matter. World War I prevented any change.

\footnotetext{
47، Joint Commission on Boundary of Baltimore and West Virginia Conferences," Official Journal of the West Virginia Conference, Methodist Episcopal Church, 1906, 103, 104. The West Virginia Conference organized the three Grant County churches into the Bayard charge. Each of these congregations maintained a membership between 30 and 50 through the Progressive Era. The annual conference soon formed the Gormania charge with five congregations, each of which averaged approximately 60 members during the period. Mineral County and eastern Grant County remained in the Baltimore Conference. See "Statistical Report," Official Journal of the West Virginia Conference, Methodist Episcopal Church, 1906, n.p.; 1910, 114; 1920, n.p.

${ }^{48}$ Raymond Fitzhugh Wrenn, "The Virginia Conference of the Methodist Episcopal Church, 1867-1906," in Those Incredible Methodists: A History of the Baltimore Conference of the United Methodist Church, ed. Gordon Pratt Baker, (Baltimore: Commission on Archives and History, The Baltimore Conference, 1972), 279; "Concerning Greenbrier District," Official Journal of the West Virginia Conference, Methodist Episcopal Church, 1905, 72; "Statistics No. 1," Minutes of the Virginia Conference of the Methodist Episcopal Church, 1906, n.p.;

49،"Resolutions," Minutes of the Baltimore Annual Conference, Methodist Episcopal Church, South, 1910, 114.
} 
Not until 1929 did the national body finally agree to transfer all portions of West Virginia belonging to the Holston Conference to the Western Virginia Conference. That annual conference also received all West Virginia territory in the Baltimore Conference except Morgan, Berkeley, and Jefferson counties. ${ }^{50}$

Methodists in the Mountains: Faith at Work

The division of mountain Methodists among so many different annual conferences did not change that fact that they were all West Virginia Methodists. As important as the episcopal structure was to Methodism, formal ecclesial boundaries did not always accurately define all congregations within their confines. Churches in Mineral and Grant counties had more in common with churches in the West Virginia and Western Virginia Conferences than they did with churches in the Baltimore or Washington, D.C. metropolitan areas. In the case of Mineral and Grant Counties, the railroad helped strengthen this bond.

In fact, by the Gilded Age, the North/South schism meant little in practical terms in the mountains. This is not to say the old divisions became meaningless, but regardless of annual or General Conference, Methodists in the mountain counties of West Virginia lived out their faith in much the same way. The MEC and the MECS remained largely conservative in their theology. They appealed particularly to the working and middle classes, especially those segments of the population employed in the emerging industrial sectors, whether blue or white collar. However, the professional and managerial classes also found the denomination very attractive in certain parts of the state.

Most notably, both branches of Methodism in the state exhibited high levels of popular religion. Despite, or perhaps because of, industrialization, these Methodists remained committed

\footnotetext{
${ }^{50}$ Burrows, et. al. 327-331, 348.
} 
to the egalitarian theology that set them apart from their founding. At the same time, they

exhibited respect for and allegiance to the episcopacy. Records of churches pre-dating

industrialization and of churches established during the Gilded Age and the Progressive Era

demonstrate this continued commitment to democratic theology and hierarchical polity. Into the

twentieth century, both the MEC and the MEC, South in the Alleghenies held these two forces,

both foundational to Methodism, in tension.

In some ways, the border dispute between the West Virginia and Baltimore Conferences

is an example of this. The disputed churches were under the authority of the Baltimore

Conference and the West Virginia Conference had to respect that fact. On the other hand, the

entire point of the Methodist organizational system was to facilitate the effective and efficient

spread of the gospel to all people in all places. The lumbermen, coal miners, and mill workers

along the conference border needed evangelizing as much as anyone. Although almost nothing

survives from those churches from this period, the work of missionaries from the West Virginia

Conference demonstrated a continued commitment to working class ministry that traced its roots

to Methodist beginnings in Britain and the United States. ${ }^{51}$

Such work was characteristic of the MEC, as well as the MEC, South, in the central

Alleghenies. Through 1920, the work was driven by local and state missionaries, but always

\footnotetext{
${ }^{51}$ Jennifer L. Woodruff Taft, “' 'Everything Arose Just as the Occasion Offered:' Defining Methodist Identity through the History of Methodist Polity," in American Denominational History: Perspectives on the Past, Prospects for the Future, ed. Keith Harper (Tuscaloosa: The University of Alabama Press, 2008), 108-111; David Hempton, "A Tale of Preachers and Beggars: Methodism and Money in the Great Age of Transatlantic Expansion, 1780-1830," in God and Mammon: Protestants, Money, and the Market, 1790-1860, ed. Mark Noll, (New York: Oxford University Press, 2002), 124-135; David Hempton, Methodism and the Empire of the Spirit (New Haven: Yale University Press, 2005), 131-150; Dee E. Andrews, The Methodists and Revolutionary America, 1760-1800: The Shaping of An Evangelical Culture (Princeton: Princeton University Press, 2000), 1-9. Andrews does point out that Methodism attracted a fair number of merchants, traders, and entrepreneurs in urban areas along the eastern sideboard of the United States during the Revolutionary and immediate post-war periods. The seeds of what Donald Dayton has termed "embourgeoisement" were inherent in the message of Methodism, although Francis Asbury warned of the dangers of city life. In any event, this phenomenon does pertain to Gilded Age and Progressive Era West Virginia and so a more in-depth discussion of it follows in the conclusion of this chapter.
} 
with the intent of joining those new converts, regardless of class, race, or gender, to

denominational structures at the state and national levels via the circuit and its constituent

churches. These new churches in the mountains and along the rail lines could fellowship directly

and indirectly with Methodists across the country.

Prior to heavy industrialization, the Methodist Episcopal Church had eighteen individual congregations in the region served by the WVC\&P, divided among four circuits. Mineral, Tucker, and Pocahontas each had one circuit. Mineral County had three churches; Tucker had five churches; Pocahontas had three. Randolph County had two station churches and one circuit with five churches. ${ }^{52}$

What became the Keyser Methodist Episcopal Church dated to 1850, making it the oldest Methodist congregation of any kind in that part of the county, which was Hampshire County. That group used exhorters to spread Methodism across the western half of the county. The men would hold meetings to prepare people for full membership in the church. While the exhorters themselves could not receive new members or baptize them, they were expected to care for the prospective members, called probationers, until a new church was organized with an ordained or at least a licensed preacher. Not all of these groups developed into congregations, but this early lay work laid the foundation for later circuits in Mineral County. ${ }^{53}$

\footnotetext{
${ }^{52}$ Statistical Report," Official Journal of the West Virginia Conference of the Methodist Episcopal Church, 1875, n.p.; "Statistical Report," Minutes of the Virginia Conference of the Methodist Episcopal Church (Baltimore: Methodist Episcopal Book Rooms, 1874), n.p.; "Statistical Report," Minutes of the Baltimore Annual Conference of the Methodist Episcopal Church (Baltimore: William K. Boyle and Son, 1875), 86, 87. Grant County also had a station church belonging to the Baltimore Conference at this time. However, the church was in Petersburg, which was not close to the WVC\&P. Mineral County also had at least one other circuit at this time located in the north-central part of the county near Fort Ashby and Frankfort, some distance from the original WVC\&P line. While eventually H.G. Davis extended a line north nearer to some of these congregations, they developed separately from the Keyser congregations, usually being on circuits with churches in Hampshire County, West Virginia or Maryland.

53“"History of First Methodist Church," (Keyser, WV: Self-Published Congregational History, n.d.), 1. See Chapter 2 on the creation of Mineral County.
} 
By 1880, Keyser MEC had become a station church, meaning it was not on a circuit with other congregations. H.G. Davis donated property for a church building and a parsonage. In addition to Thomas R. Carskadon, a farmer, prominent Unionist, and one of the wealthiest men in the county, the trustees included two teamsters, two lawyers, a gardener, and a cobbler. The stewards consisted of the postmaster, the deputy sheriff, and two carpenters. No membership records remain, but later leadership rosters hint at a middling congregation with comparatively fewer opportunities for working class members in the early $20^{\text {th }}$ century. ${ }^{54}$

A quick comparison of the various officials in the church illustrates this. The 1894 trustee roster contained Carskadon and one of the lawyers from twenty years prior; two shopkeepers, a dentist, and a coal miner rounded out the list. In 1915, the Official Board consisted of the public school superintendent, a lawyer, a postal clerk, a druggist, and two merchants. The stewards from that same year included two lawyers, two merchants, a court clerk, a circuit judge, and a carpenter. All were native-born whites, mostly from West Virginia/Virginia. $^{55}$

\footnotetext{
54،“A Brief History of First United Methodist Church,” (Keyser, WV: Self-Published Congregational History, 2006), 1; "History of First Methodist Church," 2; Tenth Census of the United States, 1880. According to the Discipline, stewards, nominated by the preacher in charge and approved by the Quarterly Conference, bore several related responsibilities. In short, they handled the finances of the circuit. They were responsible for securing money for any ministry, service, or function of the church or pastor which required funding. They ensured that the money was accurately counted, used responsibly, and then accounted for. Finally, they oversaw any charity work done, and were required to seek out those who needed money, not just wait for the needy to come to them. See "Leaders and Stewards' Meeting," Doctrines and Discipline of the Methodist Episcopal Church (New York: The Methodist Book Concern, 1912), 100, 101; and "Of Stewards," Doctrines and Discipline of the Methodist Episcopal Church, South (Nashville: Publishing House M.E. Church, South, 1910), 99, 103.

55"A Brief History of First United Methodist Church," 1; "History of First Methodist Church," 4; Twelfth Census of the United States, 1900; Fourteenth Census of the United States, 1920. An Official Board was composed of all nonordained members of a Quarterly Conference, which were usually the stewards, trustees, and any lay preachers of the various points on the charge. The Official Board performed any task assigned to it and usually coordinated the work of the stewards and class leaders. The "class" was a small group designed to encourage members to fellowship together, seeking salvation and growing in holiness. These were leveling events. Through the class meeting, non-elites could exercise leadership over their secular superiors. However, records from these churches in West Virginia do not provide enough information to determine the extent of egalitarianism in this area of Methodist life. See "Official Board," Doctrines and Disciplines of the Methodist Episcopal Church, 99, 100. Generally speak-
} 
The New Creek Circuit, which consisted of Keyser and nine other churches, maintained a steady membership of just over 300 through the 1870 s. The fact that the Keyser church had ninety members in 1880, just after becoming a station church, suggests that each of the other congregations on the circuit were small. However, Keyser grew steadily over the next forty years, reaching 448 parishioners in 1920. Another station church, located at Piedmont, and the Elk Garden circuit, represented the MEC in southwestern Mineral County. The Elk Garden circuit contained between two and four congregations. Between 1880 and 1900, each averaged about seventy members; membership increased to approximately one hundred each over the Progressive Era. ${ }^{56}$

The town of Piedmont was smaller than the city of Keyser, but the Piedmont MEC was notably larger than the Keyser MEC through 1900, after which time the Keyser church membership surpassed it. Membership records from the 1890s through the early 1920 s indicate the Piedmont church maintained a balance of agricultural and industrial members, most of whom were native-born whites. Farmers continued to join the church in noticeable numbers through the late Progressive Era. The working class membership was divided evenly between skilled and unskilled workers. Oddly enough, despite the fact that Piedmont was at the center of the early

ing, both branches of Methodism in West Virginia strongly encouraged class meetings and viewed them as valuable part of church life. See Burrows, et. al., 137; and Richey, et. al., 23, 24, 133-135.

56“"General Statistics," Minutes of the Baltimore Conference of the Methodist Episcopal Church (Baltimore: William K. Boyle \& Son, 1875), 80; 1880, 89; 1893, 113; 1900, 133; 1910, 132; 1920, 122. The city of Keyser and the town of Piedmont each had a black Methodist church at this time. These black congregations were part of the Washington Conference, an all-black conference created by the MEC in 1864 encompassing West Virginia, Virginia, Maryland, Washington, D.C. and even extending into Ohio. In 1922, the Keyser and Piedmont Charge listed 171 members. "Statistician's Report - Pittsburgh District," Official Minutes of the Washington Annual Conference, Methodist Episcopal Church, 1922, 328. What little information remains on Janes MEC (located in Keyser) shows a predominately working class congregation that was noticeably egalitarian. From its founding in 1873 to 1920, almost all of the trustees were unskilled laborers. Others included a barber, a stonemason, and a chauffeur. All of the stewards in 1920 were women. See "Janes United Methodist Church," (Keyser, WV: Self-Published Congregational History, 2006), 1. For more on the Washington Conference, see Burrow, et. al., Melting Times and Baker, ed., The Incredible Methodists. 
Davis coal empire, surviving records show no coal miners. Most of the blue-collar members worked in either the railroad or the paper and pulp industries. There seemed to be no representatives of the new elite and very few clerks and professionals. No leadership lists of any kind remain, but the extant evidence points to a working class and farming congregation, which could mean more opportunities for leadership existed there than at Keyser. ${ }^{57}$

To be sure, membership evidence is so scant that it does not rule out the possibility of upper middle and upper class members running the church. However, given the fact that the rest of the Methodist churches retained an egalitarian theology (as is demonstrated below), the first option is more likely. The Keyser MEC, then, seems to be the anomalous congregation. If it held to egalitarian theology and allowed working class members to serve, it must not have had very many working class members by the first two decades of the twentieth century. On the other hand, that church might not have been very egalitarian. Either way, it is the exception among mountain Methodists.

In 1882, the West Virginia Conference of the Methodist Episcopal Church, in advance of the railroad, created the Randolph Mission to serve parts Randolph and Tucker counties. A few years later, the annual conference created the Hambleton Mission, which consisted of parts of northern Tucker County, southwestern Grant County, and southeastern Garrett County, Maryland - all territory along the WVC\&P${ }^{58}$ The goal was to expand the work of the existing circuits in both counties, taking advantage of the increased in population that was certain to occur with the

\footnotetext{
57“Members," Piedmont First Methodist Episcopal Church,” 1888-1923, n.p. The Piedmont ME church's highest membership total between 1880 and 1920 actually occurred in 1896, when the group record 360 members. Through 1920 , it consistently registered well over 300 parishioners, except in 1910, when numbers dipped to 265 . It boasted 320 members in 1920. "General Statistics," Minutes of the Baltimore Conference of the Methodist Episcopal Church (Baltimore: William K. Boyle \& Son, 1896), n.p.; 1900, 133; 1910, 132; 1920, 122.

58،"Home Mission Report," Official Journal of the West Virginia Conference, Methodist Episcopal Church, 1882, 29. Mott, 13-15. The town referred to in the name of the circuit was actually Henry, WV, in Grant County. The current town of Hambleton, in Tucker County, was at the time called Hulings.
} 
coming of the railroad. There was no national body involved in this endeavor. While local records from the period are by no means complete, and in some cases non-existent, the extant data is revealing.

In November 1886, the Reverend S.P. Archer held a revival in Hambleton at which thirty people converted and joined the Methodist Episcopal congregation. In January 1887, he held a revival in Davis which yielded fourteen conversions, with many more joining the church, swelling its ranks to fifty members. Because the town of Davis was, at the time, the southern terminus of the WVC\&P, its population grew rapidly. The MEC church became a station that same year, with land for a building donated by H. G. Davis. ${ }^{59}$

The Davis MEC offers an interesting contrast with the Keyser church. What data remains from Davis indicates a group in which people of all classes, both men and women, consistently had access to positions of leadership. Records from the first fifteen years are spotty, but the congregation appeared solidly working class, with high numbers of industrial laborers joining in the early years. Several clerks and seamstresses also belonged. There were few farmers; the only two recognizable members of the new industrial elite were H.C. Newbury, founder of Tygart Valley Lumber Company, who soon departed for Randolph County, and S.H. Heironimus, boarding house owner and Davis company man. ${ }^{60}$

Fuller membership records from the 1910s reveal how the social composition of the congregation remained the same through the Progressive Era. A few upper class people belonged, including the wives of a coal operator and of a lumber dealer; the roll also included a

\footnotetext{
${ }^{59}$ Mott, 16. By 1895 , the church already had 150 members. Membership hovered between 140 and 150 through the Progressive Era. "Oakland District Report," Official Journal of the West Virginia Conference, Methodist Episcopal Church, 1895, n.p.; 1900, 66, 67; 1910, 114 ; "Elkins District Report," 1920, n.p.

${ }^{60}$ Mott, 19-23; Twelfth Census of the United States, 1900.
} 
few farmers. However, the majority of members hailed from the industrial working class, including particularly large numbers of day laborers, tannery workers, and coal miners. Low level clerical workers comprised a sizeable minority of the congregation. ${ }^{61}$

The rosters of trustees and stewards from the same years demonstrate that both skilled and unskilled had every chance to serve in various leadership capacities. H.D. Heironimus served as a trustee and steward, as did a lumber dealer. Day laborers held both offices as well, and women functioned as stewards. Official Board rosters through 1920 also show the same thing. Newbury and Heironimus served on the Official Board, but so did numerous day laborers and mill hands. Mill foremen, carpenters, and engineers also occupied the list. Women consistently comprised roughly one-third of the membership, and were usually wives, sisters, or daughters of working class men. ${ }^{62}$

Women did not play such roles in all Methodist churches in the Alleghenies. However, their involvement in the Davis church reflected the traditional egalitarianism of Methodism. From the beginning, John Wesley permitted women to exercise comparatively significant influence and leadership. They were allowed to speak on occasion, but would not be allowed to preach officially or to be ordained. This general rule carried over to America, but, as demonstrated just by the small sample of congregations here, was not uniformly applied. However, generally speaking, into the early twentieth century, women enjoyed more opportunities in Methodist congregations than they did in Baptist or Presbyterian churches. ${ }^{63}$

\footnotetext{
${ }^{61}$ Mott, 25, 26.

${ }^{62}$ Mott, 23, 24; Thirteenth Census of the United States, 1910; Fourteenth Census of the United States, 1920.

${ }^{63}$ Richard P. Heitzenrater, Wesley and the People Called Methodists (Nashville: Abingdon Press, 1995), 237, 247, 248; David Hempton, Methodism: Empire of the Spirit (Hew Haven: Yale University Press, 2005), 138-150.
} 
The Davis congregation is the only MEC church in Tucker County with such substantial records. However, the scraps of information that remain from other churches suggest the Davis congregation was representative of the denomination in the county. The Quarterly Conference of the St. George Circuit, which included the oldest church of any denomination in the county, had big and small farmers on its roster, as well as farm workers. Although that particular charge was located in the least industrialized part of the county, a few industrial workers attended these meetings. The Thomas MEC leadership lists from the turn of the century show a roughly equal gender distribution among the stewards and trustees. Almost all of the men were miners or laborers; none were from the industrial or agricultural elite. The class leaders were working class as well. Likewise, the Official Board of the Hambleton (Hulings) MEC, formed in 1902 in a logging and railroad community, looked remarkably similar to that of Davis MEC at the same time. From 1912-1914, women comprised most of the board of stewards. Most of them did not work outside of the home and their husbands were unemployed. A merchant, a physician, a farmer, and a saw mill laborer made up the trustees. Most Tucker County Methodists were native-born whites, but comparatively few were originally from West Virginia/Virginia. Most came to the state from Pennsylvania or Maryland. ${ }^{64}$

Annual conference minutes reveal that Methodism enjoyed considerable success in the county. By 1910, the St. George Circuit consisted of six churches with a total membership of 300. A church had been established in Parsons in 1892 and by 1900 the circuit had 163 people; membership peaked at 265 in 1910 before sliding to 205 in 1920. The Hendricks Circuit, which included Hendricks, Hambleton, and three other churches, grew from 173 to 255 members

\footnotetext{
64،"Quarterly Conference Records,” St. George Circuit, MEC, 1880, n.p.; "History of Thomas Methodist Episcopal Church," First Methodist Episcopal Church, Thomas, n.d, n.p.; "Official Board," Hambleton Methodist Episcopal Church, 5-85; Tenth Census of the United States, 1880; Twelfth Census of the United States, 1900; Thirteenth Census of the United States, 1910; Fourteenth Census of the United States, 1920.
} 
between 1910 and 1920. A station church in Thomas maintained a membership approaching two hundred through the period. ${ }^{65}$

During the same period, Methodists also enjoyed success in Randolph County, again building off an existing ecclesiastical foundation. An ME congregation existed in what became Elkins since the denomination schism. However, with chronically low membership, it teetered on the brink of dissolution through the 1870s and 1880s. In 1890, the Randolph Mission finally established a viable station church in the new town of Elkins, reflecting its growing importance to the region and the success of H.G. Davis's industrial empire. Between 1895 and 1905, the congregation increased from 90 to 320 members. By 1920, it boasted nearly 1100 members, making it the largest church in the county and the largest along the West Virginia Central and Pittsburg mainline. ${ }^{66}$

Fragmentary church records indicate a predominately working class congregation whose members likely moved into the area looking for jobs. Many of these were single men living at the Odd Fellows Home. Several skilled workers and clerks transferred their memberships to the Elkins church from various congregations in Tucker County. A list of stewards and class leaders from 1912-1913 is the only surviving list of church leaders, but it gives a glimpse at the social diversity of the congregation and its egalitarianism. The roster included two lumber manufacturers, four factory foremen, three clerks, and three unskilled laborers. ${ }^{67}$

\footnotetext{
65“'Oakland District,” Official Journal of the West Virginia Conference, Methodist Episcopal Church, 1890, 89; 1900, 48; 1910, 101; “Elkins District Report," 1920, 75, 145.

${ }^{66}$ Hallie Kyle, ed., "Methodist Episcopal Church, 1890-1904,” Our Church History: Woodford United Methodist Church (Elkins, WV: Self Published, 1987), n.p.; "Buckhannon District Report," Official Journal of the West Virginia Conference, Methodist Episcopal Church, 1870, n.p.;1888, n.p.; 1895, n.p; 1905, 74; "Elkins District Report," 1920, 78 .

67“Chronological Register," Elkins Methodist Episcopal Church, 1897-1920, n.p.; "Register of Stewards,” Elkins Methodist Episcopal Church, 1912-1913, n.p.; Twelfth Census of the United States, 1900; Thirteenth Census of the United States, 1910; Fourteenth Census of the United States, 1920.
} 
Membership lists from other particular congregations no longer exist, but annual conference records give a glimpse of denominational growth between 1880 and 1920. The Montrose Circuit, which encompassed the northern part of the county and lay along the rail route between Elkins and Parsons, flourished during the period. By 1895, it had grown to four churches, and the membership steadily increased to over one hundred. Membership declined by about one-third over the next twenty years, but by 1920 had completely rebounded. The Mingo congregation, the southern-most in the county, struggled, never had more than seventy members, and faded from the records after 1914. The Beverly Circuit, which had five congregations in the late 1870 s, shrank to three by 1895 . It lost one-third of its membership between 1890 and 1905 , reaching a low of 200 parishioners. Over the next fifteen years, however, the charge experienced a significant increase in membership, having 417 congregants in $1920{ }^{68}$ The resurgence coincided with the coming of the WVC\&P.

Clearly, the Methodist Episcopal Church prospered in the mountains. By 1920, the MEC had a total of nineteen circuits and forty-three individual congregations in the mountain counties. Mineral County had three circuits with a combined six churches; Grant County also had three circuits with nine churches, and Randolph County had three circuits with eight churches. Tucker County claimed five circuits with ten congregations. Finally, Pocahontas County had four circuits with ten congregations. ${ }^{69}$

\footnotetext{
68“"Buckhannon District Report," Official Journal of the West Virginia Conference, Methodist Episcopal Church, 1895, n.p; 1900, 100; "Ronceverte District Report,” 1910, n.p.; "Elkins District Report,” 1920, 78.

69"General Statistics," Minutes of the Baltimore Conference of the Methodist Episcopal Church (Baltimore: William K. Boyle \& Son, 1920), 122; "Elkins District Report," Official Journal of the West Virginia Conference, Methodist Episcopal Church, 1920, 78. The MEC had two circuits - Edray and Durbin - with five churches between them in Pocahontas County by the early twentieth century. By 1920, two more circuits had formed: one at the mill town of Cass and the other at Frost, near Durbin. Cass struggled, but Frost registered 150 members. The Edray Circuit increased to seven churches, but each claimed around forty members. The Durbin Circuit, with just one congregation
} 
The Methodist Episcopal Church, South did not create any specific missionary endeavors in this territory at either the state or the national level. Rather, they simply added new churches as necessary, ensuring that these new circuits and houses of worship received sufficient financial support for as long as necessary. By 1880, Mineral County had three Southern Methodist churches, two on one circuit and the other a station church. The circuit in Tucker County included seven churches. Randolph County had two mission circuits, Randolph and New Interest, with three and four churches respectively, and there were four churches in Pocahontas County divided between two circuits. In total, Southern Methodists had twenty-one churches and six circuits. $^{70}$

Extensive records from the Southern Methodist church in Keyser display a relatively socially-balanced congregation, with approximately even numbers of industrial workers (skilled and unskilled), professionals, clerks, and merchants attending. Farmers and farm laborers made up a small but noticeable minority. In contrast to the ME church in the town, the ME Church, South seemed much more egalitarian. Leadership records from the 1890s through the 1910 show that the working class consistently played an important part in church life. Skilled and unskilled workers comprised at least half of the board of trustees through 1910. The rest were clerks and merchants, with no elite members serving in this capacity. Over half of the stewards, which did include women, were unskilled laborers. Most of the rest were skilled workers and tradesmen.

at the time, had 225 parishioners. No specific membership records survive for any of these. See Ronceverte District Report," 1910, n.p.; "Elkins District Report," 1920, 78.

70“"Statistical Report,” Western Virginia Conference Journal, Methodist Episcopal Church, South, 1878, n.p.; "Statistical Report," Minutes of the Baltimore Annual Conference of the Methodist Episcopal Church, South (Baltimore: King Brothers, 1876), 74, 75. The MEC, South Baltimore Conference also contained a mission church in Petersburg, West Virginia. 
The only representative from the upper middle and upper classes was a coal operator, who was one of the few such people in the entire congregation. ${ }^{71}$

The Keyser MECS achieved even greater numerical success than did its MEC counterpart. During the 1870 s, it was a small station church with fewer than 100 people. Through the 1880s and 1890s, it was part of a charge with three other churches, each averaging at most about 65 members by the 1890s. Around the turn of the century, however, it became a station church again and began to grow quickly (this does not imply a necessary causal relationship between being a station church and gaining new members). In 1900 it boasted 257 members. Ten years later that number increased to 317, and by 1920 it claimed 628 congregants, making it by far the largest Protestant church in the county. ${ }^{72}$

Records from the Davis MECS are much less complete than those of the Keyser church or those from the Davis MEC. However, what little remains from the late nineteenth century hints at the continued and consistent application of egalitarian theology in Southern Methodism in West Virginia. In 1892, the Reverend I. A. Canfield organized the church with eight members. At the time, Canfield also pastored in the nearby town of Thomas. The following year, his

\footnotetext{
71،"Register of Communicants," Keyser MECS, 1882-1917, n.p; "Record of Trustees,” Keyser, MECS, 1894, 1907, n.p.; "Minutes of the Quarterly Conference," Keyser Station, 1908, n.p; Tenth Census of the United States, 1880; Twelfth Census of the United States, 1900; Thirteenth Census of the United States, 1910; Fourteenth Census of the United States, 1920. Nearly all members were native-born whites, most in-migrants from Pennsylvania and Maryland.

72،"Statistical Report," Minutes of the Baltimore Annual Conference of the Methodist Episcopal Church, South, 1876, 87; 1885, 70, 71; “Table 1," 1890, 86, 87; 1900, n.p.; 1910, n.p.; 1920, n.p. The Piedmont Circuit matched its MEC counterpart in membership. Between 1880 and 1900, the two-point charge averaged approximately 150 congregants. Over the next twenty years, membership climbed steadily over 200, reaching 250 per church in 1920 . The social composition of the Southern Methodist circuit mirrored that of the MEC charge. See the statistical reports cited above. The few surviving membership records between 1880 and 1920 show a balanced congregation. Even early in the Gilded Age, notable numbers of the industrial working class (mostly railroad employees) joined the church, something which is not surprising given the town's location on the Baltimore and Ohio. But even after Davis built his commercial empire around the community, the churches continued to attract farmers. Interestingly, like the MEC circuit, this one seemed to have very few coal miners, clerks, or professionals. No one from the new upper middle or upper classes appeared on the roster. "Members," St. John's Methodist Episcopal Church, South, 18801920, n.p.
} 
charge included Davis, Thomas, Coketon, and two mission Sunday Schools. In 1894, F.S.

Landstreet, manager of the Davis Coal Company and a director of the WVC\&P, donated land and money for a building. The church was renamed "Landstreet Memorial Methodist Episcopal Church, South" in memory of his father, Reverend John Landstreet, a minister in the Baltimore Conference who preached at St. John's MECS in Piedmont in the 1870s and 1890s. The younger Landstreet, however, belonged to the local Presbyterian church. That same year, the pastor conducted a revival which lasted for three months. What records exist from the earliest years of Landstreet Memorial show a predominantly industrial, working class group, along with some farmers and a couple of clerks. The trustees and stewards, all men, reflected that social composition, with a physician being the only professional on either list. ${ }^{73}$

The Thomas and Davis congregations reached respectable numbers over the course of the Progressive Era. However, considering the fact that they were located in new railroad towns which consistently rivaled and even surpassed the county seat of Parsons in terms of population, church growth was really rather unremarkable, but still higher than the local ME churches. In 1900, the three-point circuit claimed just fifty-seven members. A decade later, that number had risen to 235 for the now two-point charge. By 1920, church rolls contained 211 names. While this growth might not be considerable, nevertheless, church membership did increase. By contrast, the St. George Circuit, completely bypassed by the railroad, slowly lost members. In 1886, this eight-point charge included 511 members. By the turn of the century, membership had fallen to 360 , but the number of churches on the charge also decreased to six. Thus, average membership per congregation remained about the same over the roughly fifteen-year period. Ten years later, there were four congregations with a total of 300 people. By the end of the

\footnotetext{
${ }^{73}$ Mott, 45-49, 84. See also Chapter 5 for more on F.S. Landstreet's involvement in the Presbyterian church. The racial and ethnic composition of Landstreet Memorial mirrored that of other congregations in the area.
} 
Progressive Era, however, the number of parishioners had fallen to 200, while the number of congregations returned to six. $^{74}$

Records from the Southern Methodist churches in Elkins (Randolph County) also depict a group committed to traditional Methodist egalitarianism while at the same time mirroring the social and economic changes taking place in and around the town and the region. In 1895, the newly created Elkins Circuit claimed 185 members in its single organized congregation. Just five year later, the church counted 300 people on its roll. Then, for whatever reason, membership began to decline. By 1910, Elkins and Parsons (in Tucker County) had been put on one charge with not even 300 people attending five local churches. That arrangement did not last long, and within a few years the two county seats were on different charges again. Lower numbers continued to plague the Elkins Circuit, which had just fewer than 200 parishioners divided among four congregations in 1914. By comparison, the Parsons Circuit had three local churches and 261 congregants that same year. Over the next half-decade, the Elkins Circuit experienced some growth, reaching 317 members by 1920; the Parsons Circuit plateaued through the remainder of the Progressive Era. ${ }^{75}$

Fewer circuit and individual congregational records exist for the late nineteenth century, but those that do show that the old agricultural order continued to dominate the church during the early 1890s, when the town of Elkins was still very young. The church dated to the antebellum period, so the majority of the members in the Gilded Age were most likely still farmers and farm workers. In 1892, most of the trustees of the Elkins congregation were farmers, but one owned a

\footnotetext{
74،"Statistical Report," Western Virginia Conference Journal, Methodist Episcopal Church, South, 1900, n.p.; 1910, n.p.; 1920, n.p.

75“'Statistical Report,” Western Virginia Conference Journal, Methodist Episcopal Church, South, 1895, n.p; 1900, n.p; 1910, n.p.; 1914, n.p.; 1920, n.p. Prior to being joined with Elkins area congregations, the Parsons MECS was part of the six-point Parsons Charge which registered 364 members. Reasons for the sudden drop in membership are unclear. Prior to getting its own charge, the Parsons congregation belonged to the St. George Circuit.
} 
general store and another was a saw mill foreman. Farmers still joined the church, but more and more merchants and industrial workers, most from out of state, filled the pews. The pastor held revivals in nearby towns which had also sprung up along the railroad, consistently reporting dozens of converts. Preachers from across the state came to aid in these endeavors. Detailed membership records from 1910-1920 evince a shift from an agrarian congregation to an industrial working class and lower middle class body. Industrial elites did not take the place of farmers in the church or in the leadership. Based on available records, unskilled laborers from various enterprises comprised at least half the congregation. Skilled workers, most of them employed by the WVC\&P, tradesman, and clerks made up most of the rest of the church. ${ }^{76}$ Like other Methodists churches in the area, the Elkins MEC, South maintained a strong commitment to egalitarian theology within the hierarchical denominational structure. Detailed leadership records from the 1910-1920 highlight how that particular congregation successfully held those two pillars of Methodism in tension. Interestingly, Southern Methodists in the town did not have women officers, unlike their local MEC counterparts. However, men from all classes exercised leadership and power within the group. In fact, as the Progressive Era progressed, working class men appeared to enjoy greater opportunities. From 1911-1914 (the only years available), the trustee and steward boards consisted entirely of merchants, tradesmen, and professionals. Towards the end of the decade, however, unskilled and skilled laborers consistently made up one-third to one-half of each. Perhaps even more indicative of Methodism's egalitarian/hierarchical continuum were the local preachers and exhorters. From

\footnotetext{
${ }^{76}$ Hallie Kyle, ed., "Methodist Episcopal Church, South, 1912-1987," Our Church History: Woodford United Methodist Church (Elkins, WV: Self Published, 1987), n.p.; "Letter to the Union Association," First Baptist Church of Elkins, 1894, n.p.; Twelfth Census of the United States, 1900; Thirteenth Census of the United States, 1910; Fourteenth Census of the United States, 1920.
} 
1918-1921 (again, the only years available), unskilled industrial workers held these positions exclusively; one of the exhorters was a fifteen-year-old janitor at the YMCA. $^{77}$

Thus, this congregation seemed to have robust local interest in serving the religious community. At the same time, the Elkins Circuit was regularly staffed by an ordained elder. He most likely primarily served the Elkins congregation, which was by far the largest on the charge. However, throughout the period there were two to four other congregations on the charge that needed a minister. Local preachers probably would have been used frequently to serve these other bodies. Granted it is an argument from silence, but nothing suggests any serious tension or disagreement between lay and ordained clergy.

A quick comparison between the Elkins church and the Mingo Circuit highlights the impact the railroad had on the social composition of churches. The Elkins congregation began to shift from an agrarian congregation to an industrial one quickly. Records show a complete transformation by 1910, twenty years after the coming of the railroad, but that change could have taken place several years earlier. Unfortunately, no records from any congregations in Beverly, the county seat before Elkins (see Chapter 3), survive. Residents of that town delayed the railroad long enough for Elkins to become the terminus, thus depriving themselves of any benefits (and maybe saving themselves from injuries) associated with being a hub of transportation and commerce. The Iron Horse eventually came to town, as did some industry, but Beverly never rivaled Elkins in the new economy. Without church records, it is impossible to chart the precise effect industrialization had on Methodist churches in Beverly, although it is likely the same process occurred there as in Elkins, albeit on a smaller scale.

\footnotetext{
${ }^{77}$ Hallie Kyle, ed., "Methodist Episcopal Church, South, 1912-1987," Our Church History: Woodford United Methodist Church (Elkins, WV: Self Published, 1987), n.p.; Thirteenth Census of the United States, 1910; Fourteenth Census of the United States, 1920.
} 
Some records do exist, however, for the Mingo Circuit, which included congregations in the remote regions of the southern-most parts of Randolph County. Neither the mainline nor any branch lines of the WVC\&P reached this area; feeder tracks transporting lumber represented its only presence in that section of the county, and those only went to the lumber camps, not to the residential communities. Thus, agriculture continued to dominate. As one might expect, then, church congregations consisted mostly of farmers. Steward lists from the mid-1880s show only farmers and farm laborers, which shows some commitment to egalitarianism, despite an understandable lack of social diversity. Membership records from the mid-1910s reflect increased timbering, with a few lumbermen and several of their wives joining churches on the circuit. However, it seems that farmers still constituted a majority of individual congregations. ${ }^{78}$ Ironically, the comparatively remote location of the Mingo Circuit meant that its numbers declined only slightly over the period. Unlike Beverly, which had to compete with nearby Elkins, there were no rapidly developing communities served by the Mingo Circuit. Population, and thus members, were not siphoned or re-directed somewhere else. In 1895, with four congregations, the total circuit membership stood at 185 . At the turn of the century, membership declined to 150 before steadily increasing over the next fifteen years. Two additional congregations were added to the circuit over that time. By 1920, the circuit contained nine local churches and recorded a total membership of 285 people. $^{79}$

\footnotetext{
78،"Minutes of the Quarterly Conference," Mingo Circuit, MEC, South, 1884-1886, n.p.; 1915, n.p.; Tenth Census of the United States, 1880; Thirteenth Census of the United States, 1910; Fourteenth Census of the United States, 1920.

79“"Statistical Report,” Western Virginia Conference Journal, Methodist Episcopal Church, South, 1890, n.p.; 1900, n.p.; 1915, n.p.; 1920, n.p. In the 1880s, the congregations in the Mingo area had been part of the Randolph Circuit, which encompassed all territory from Elkins south to Pocahontas County. In the mid-1880s, the New Interest Circuit, consisting of the area north of Elkins to the Tucker County line, apparently folded into the Randolph Circuit. Not until 1895 did the annual conference begin to carve the county into multiple circuits again.
} 
Church data from Pocahontas County congregations more clearly demonstrates the commitment to traditional Methodist theology and the influence of the railroad. While by no means complete, records for Huntersville, the old county seat, and Marlinton, the new county seat (see Chapter 3), are detailed enough for substantial and insightful comparison. A Methodist congregation existed in Huntersville since at least the 1840s, when it shared a meeting house with other denominations. ${ }^{80}$ Between 1900 and 1920, the size of the charge fluctuated between one and five churches. The circuit listed well over 100 members before industrialization. For a brief time after the railroad went to Marlinton, it maintained a sizeable congregation, topping out at 251 members for the single church in 1905 . However, decline set in quickly before plateauing. By 1910, four churches on the charge had a combined 170 members. A decade later, the circuit expanded to six congregations with 283 members between them. ${ }^{81}$

The churches on what became the Marlinton Circuit had been a part of the Edray Mission in the 1870s and 1880s. The annual conference supplied this circuit with a missionary pastor. The creation of the town of Marlinton and the coming of the railroad helped stabilize these groups, which became part of the Huntersville Circuit through the 1890s and early 1900s. The Edray Mission had about one hundred parishioners, and in its early years the Marlinton Circuit, which reported statistics from one to three churches, contained about 175 members. The second decade of the twentieth century, however, witnessed considerable and steady growth, and the circuit claimed 360 people by $1920 .^{82}$

\footnotetext{
${ }^{80}$ William Price McNeel and Jane Price Sharp, eds. History of Pocahontas County, West Virginia, 1981: Birthplace of Rivers (Marlinton, WV: Pocahontas County Historical Society, 1981), 128. See this book for more on Methodism in the county, including brief histories of several smaller congregations.

81 "General Statistics," Minutes of the Baltimore Conference of the Methodist Episcopal Church, South, "General Statistics," 70, 71; "Table 1," 1905, n.p.; "Table 1," 1910, n.p.; "Table 1," 1920, n.p.

82 "General Statistics," Minutes of the Baltimore Conference of the Methodist Episcopal Church, South, 1876, 85; 1885, 70, 71; “Table One," 1900, n.p; 1910, n.p.; 1920, n.p.
} 
Interestingly, membership lists from the newly created Marlinton Circuit show a primarily middling congregation consisting mainly of clerical workers and professionals, despite the town and county's dependence on extractive industries. Farmers still made up a sizeable minority of the group, with a mill owner representing the industrial elite. Unlike other Methodist churches studied here that were located along the railroad, however, this one had few members of the industrial working class among its ranks. ${ }^{83}$

Leadership records from 1900-1915 reflect this middle class numerical superiority, but they also show that lower class members did have at least some leadership opportunities. A day laborer did serve as trustee/steward in the early twentieth century, along with two large farmers, two store owners, a real estate agent, a lawyer, a lumber dealer, and the town mayor. ${ }^{84}$ This relatively bourgeois composition did not dampen religious enthusiasm. Although in some ways Marlinton Methodists were very much a product of the new industrial economy, revivalism appeared to play a major role in their collective religious life, as it had for American Methodists since the Second Great Awakening.

Cooperation between God and people was commonplace in Protestant revivalism in general and in Methodist theology in particular. Preachers and parishioners exhibited great interest in revivals from 1900-1920. With so much outward excitement, the church prayed "for manifestations of the Spirit working in a gracious revival." ${ }^{\circ 5}$ Continuing to keep with tradition, these were extended events. The pastor and the congregation, "with the assistance of the Lord,"

\footnotetext{
${ }^{83}$ "Register of Members," Marlinton Circuit, MEC, South, 1906, 1-14; Twelfth Census of the United States, 1900; Thirteenth Census of the United States, 1910; Fourteenth Census of the United States, 1920.

84“"Report of the Quarterly Conference," Marlinton Circuit, MEC, South, 1906-1915, n.p; Twelfth Census of the United States, 1900; Thirteenth Census of the United States, 1910; Fourteenth Census of the United States, 1920.

${ }^{85}$ “Report of the Quarterly Conference," Marlinton Circuit, MEC, South, 1907-1908, n.p.
} 
prepared for a week in advance of the "revival proper," which itself probably lasted at least a week. They held three prayer meetings a night seeking "refreshing from on high." $"$ The membership spike in the 1910s could in part be explained by these and other fervent efforts.

The Huntersville Circuit shared this zeal for religious awakening. From 1898-1919, constituent churches held revivals almost every year, and sometimes more than one annually. As could be expected, these meetings lasted several days, usually averaging about ten days. Quarterly Conference reports indicate they were all well-attended, with several converts being made each time. In 1914, revivals helped add 130 people to the church roll. Like their coreligionists a century earlier, they also held protracted gatherings in conjunction with other denominations, specifically Baptists and Presbyterians. Such a practice was also not uncommon for the early twentieth century (see Chapters 5 and 6). ${ }^{87}$

As they built new rail lines, industrial capitalists bypassed Huntersville, as they had St. George, the old county seat of Tucker County (see Chapter 3). This meant Huntersville did not experience the social and economic changes of its rival, Marlinton. Thus, it should come as no surprise that farmers made up a majority of parishioners. There were a few clerks and professionals, as the town did grow. Most members from the new industrial segment of the economy were lumber camp workers and their wives and children. No elite citizens appear in the records. However, despite the agrarian majority, by the end of the period few farmers occupied positions of church leadership. Records are very scarce, but those that remain almost make it seem like churches on the Huntersville Circuit may have been trying to mimic their brothers and sisters in Marlinton. Most of the stewards, for example, were merchants and

\footnotetext{
86،"Report of the Quarterly Conference,” Marlinton Circuit, MEC, South, 1915, 1.

87،"Report of the Quarterly Conference,” Huntersville Circuit, MEC, South, 1898-1919, n.p.
} 
professionals, with no officers coming from among laboring members. ${ }^{88}$ Perhaps this rural congregation wanted to at least appear more connected with the economic progress experienced by communities along the railroad.

Overall, the ME Church outnumbered the MEC, South in West Virginia by a considerable margin. However, the numbers here suggest that Southern Methodists successfully matched, and in some ways exceeded, MEC work in the mountains. Exact membership figures are difficult to count, but by 1920 the MECS had a total of seventeen circuits and seventy-two individual congregations. Mineral County had six circuits and twenty-one congregations. Tucker County had three circuits and twelve congregations (some of these were in Grant County). Randolph had three circuits and nineteen congregations, while Pocahontas had five circuits and twenty churches. $^{89}$

\section{Conclusion: Popular Religion and Embourgeoisement}

Methodism's success in the mountains should really come as no surprise. The MECS and the MEC experienced roughly even growth in the Alleghenies throughout the period. These results seem to mirror those of both branches statewide. By 1920, the West Virginia Conference of the MEC reported 78,969 members. The Western Virginia Conference of the MECS reported

\footnotetext{
${ }^{88 ، " R e p o r t ~ o f ~ t h e ~ Q u a r t e r l y ~ C o n f e r e n c e, " ~ H u n t e r s v i l l e ~ C i r c u i t, ~ M E C, ~ S o u t h, ~ 1898-1919, ~ n . p . ~}$

89"'Statistical Report," Western Virginia Conference Journal, Methodist Episcopal Church, South, 1920, n.p.; “Table," Minutes of the Baltimore Conference of the Methodist Episcopal Church, South, 1920, n.p. To be clear, not all of these congregations, nor the ones in the MEC, are in the area immediately served by the WVC\&P and its branch lines. Denominational records do not list all the specific individual congregations on a given circuit. Thus, some circuits include churches in towns along or near the railroad and churches in towns by-passed by the route. Furthermore, circuit boundaries did not adhere to county borders. Thus, some of the circuits probably included a few churches not in counties considered here. In any event, these numbers are not intended to be exact figures of churches only along the WVC\&P. Rather, they are presented here to give an idea of the growth of Methodism in the Allegheny region of West Virginia as a whole and in one segment of it in particular. Methodism as a whole remained the largest Protestant denomination in the state, followed by Baptists and the Presbyterians. Divided into subgroups, the order went MEC, NBC, MECS, PCUS. By way of comparison, there were just 50,000 Catholics in the state as late as 1914. See Manfred O. Meitzen, "West Virginia," in Religion in the Southern States: A Historical Study, Samuel Hill, ed. (Macon: Mercer University Press, 1983), 369.
} 
32,342 parishioners. ${ }^{90}$ Both groups more than doubled their membership in West Virginia between 1880 and 1920. In terms of absolute numbers, the MEC fared much better, but proportionately, the two groups did about the same.

Methodism's popularity in the Alleghenies and in West Virginia coincided with a slow but steady decrease in Methodist membership in the United States as a whole. Between 1850 and 1890, growth remained stable. Between 1890 and 1926, it declined significantly. ${ }^{91}$ Methodist scholar David Hempton points out that, historically, Methodism has thrived under two conditions. First, it must remain energetic and enthusiastic about religious life and bringing others into that life. Second, and perhaps more importantly, the denomination needs a relatively fluid and unstable social environment. Places experiencing rapid population growth and social and economic upheaval provide more fertile soil than older, more established communities. ${ }^{92}$

As this study has shown, the territory served by the West Virginia Central and Pittsburg fit this description well during the Gilded Age and the Progressive Era. Even cities such as Piedmont and Keyser, which had been along the Baltimore and Ohio for decades, underwent substantial additional transformations as a result of Davis's enterprises. The railroad literally revolutionized areas deep in the mountains of Grant, Tucker, Randolph, and Pocahontas counties. At the same time, this study shows, both here and in Chapter 8, that mainline Methodism in West Virginia still placed specific religious demands on parishioners. While there is no solid evidence

\footnotetext{
90"Statistical Report," Official Journal of the West Virginia Conference, Methodist Episcopal Church, 1920, n.p.; "Statistical Report," Western Virginia Conference Journal, Methodist Episcopal Church, South, 1920, n.p. Again, keep in mind that these numbers do not represent the total number of adherents of either denomination in West Virginia. The Baltimore Conference of each branch still included Methodists in West Virginia, and those members are not counted in these figures. By this time, the Western Virginia Conference (MECS) was actually slightly larger geographically than the West Virginia Conference (MEC).

${ }^{91}$ Roger Finke and Rodney Stark, The Churching of America, 1776-2005: Winners and Losers in Our Religious Economy (New Brunswick, NJ: Rutgers University Press, 2005), 157.

${ }^{92}$ Hempton, 199, 200.
} 
of the holiness movement per se in the mountains at this time, a particular conception of holy living in general still prevailed in the church. This involved, as shown in Chapter 8, various social stances and behaviors, or, in the case of alcohol, abstention from certain behaviors. They also involved, as shown above, an expectation of participation in various events in the life of the local church, the circuit, and the annual conference, as well as the shouldering of religious responsibility.

Many of these events and responsibilities demonstrated popular religion. Methodism offered the laity more opportunities to serve and lead than any other mainline denomination (and probably at least as much as any other Protestant sect). A few of these were outlined and discussed above. Lay offices such as steward or class leader allowed any member, male or female, rich or poor, to exercise authority in the church in ways reflective not only of traditional Methodist understandings of the faith, but also of the various roles played by people in the early church. ${ }^{93}$ Stewards, for example, performed duties similar to those chosen by the Apostles in Acts 6:1-7. Those men supervised the care and provision for those in need. In a sentence, that was the job of a steward. As discussed in Chapter 6, Baptists assigned these jobs to deacons. Unlike Baptists in West Virginia, Methodists allowed women to exercise some spiritual authority as well. The class leader shepherded a small group of people. While the pastor bore the ultimate responsibility for the spiritual well-being of every person in the congregation, individual class leaders interacted with parishioners on a more immediate and intimate level, encouraging them to grow in holiness, as both Jesus and Paul did with the first Christians. The Book of Acts and the Epistles contain numerous verses about close fellowship which surpasses a single weekly

\footnotetext{
${ }^{93}$ Peter W. Williams, Popular Religion in America: Symbolic Change and the Modernization Process in Historical Perspective (Englewood Cliffs, NJ: Prentice-Hall, 1980), 134.
} 
gathering (see, for example, the Acts 6:1-7 passage, as well as Hebrews 3:13 and 4:12, among

many others).

Lay men of all social classes could serve as local preachers or exhorters, directly bringing a message of God to the people and teaching them about the Bible. Often uneducated, and in the Alleghenies certainly without any formal theological or religious training, those men based their preaching and teaching on their own personal experience and meditations on Holy Writ. ${ }^{94}$ Their ministries in particular, and lay ministry in general, represent what religious scholar Charles Lippy identifies as the central aspect of popular religiosity in Appalachia - a sense of divine power accessible to humans. ${ }^{95}$ God could use anyone: divine power was available to anyone at any time. Education, wealth, and social standing, or any other material qualifier, were not required for effective ministry. Even Lippy admits that most frequently mentioned examples of this aspect of popular religion include faith healing, speaking in tongues, and snake handling. Compared to those ecstatic religious experiences, preaching may seem mundane.

But such a view misses the point entirely, especially when considered in the context of Methodism. First, preaching, teaching, and holy living stood at the very center of the Christian mission to the world. Jesus himself commanded his disciples to teach people and make disciples

\footnotetext{
${ }^{94}$ Recall that Methodism as a whole did not expressly prohibit women from serving as lay preachers or exhorters. That authority was reserved to the various general conferences, and at times even to the districts and circuits. In this particular part of West Virginia, women did not serve in these positions. No evidence suggests they were barred from these offices conference-wide, although that is certainly possible.

${ }^{95}$ Charles Lippy, "Popular Religiosity in Central Appalachia," in Christianity in Appalachia: Profiles in Regional Pluralism, Bill J. Leonard, ed. (Knoxville: The University of Tennessee Press, 1999), 41-42. Lippy and others, e.g. McCauley, are clear that the development of popular religiosity is/was not solely based on a lack of power in the secular sphere. Certainly, that is one factor involved, especially during the upheaval of industrialization. Popular religion did enable those without power in the secular world to exercise power in the sacred sphere. However, the divine power that denominations such as Methodism represented was not contingent upon anything, or lack thereof, on earth. People may have been attracted to Methodism because of its egalitarian theology, but that theology in and of itself was not inherently a function of a particular socio-economic setting. The beliefs and characteristics of popular religion also reflect a genuine belief in a God who wants to work through individuals in certain ways and at the same time is no respecter of persons. Thus, the attraction to and development of popular religiosity stems from a complex of factors, not a single, often simplistic, cause.
} 
of them (Matt. 28:16-20). The first mention of glossolalia in the New Testament is in the context of preaching. The Holy Spirit enabled the disciples to speak in other languages so that they might proclaim the gospel to Jews from other countries visiting Jerusalem during Pentecost, or the Festival of Weeks (see Acts 2:1-13 and Exodus 34:22).

Second, preaching and teaching are inherently communal in nature, and this has particular significance for Methodism. As Lippy highlights, the more well-known manifestations of mountain popular religion often focus on the individual. Through the gift of tongues, faith healing, or serpent handling, God gives power to a single person and the individual's faith is validated and strengthened. To be sure, these practices certainly held collective significance and places in public worship, but the emphasis remained on God's ability and willingness "to sustain the individual in the ordinary course of life." 96 By contrast, the primary goal of preaching/teaching is to bring people together. It is something that cannot be effectively exercised or experienced outside of a group. It is the means by and through which God creates, facilitates, and sustains connection. That is the point of Methodism.

The power that the preacher and teacher yields in Methodism is still very much one that reflects individual faith and piety. The end of that power, however, is not the edification of the

\footnotetext{
${ }^{96}$ Lippy, 43. In I Corinthians 14:1-5, Paul specifically states that preaching (prophecy) is more beneficial than tongues in public worship. Earlier in Chapter 12, Paul also writes that spiritual gifts are to be used for the common good. Thus, the case could be made that those most commonly associated with mountain religiosity did in fact reflect a priority on community, rather than individuality, or at least a balance between the two. However, the secondary literature and the primary sources indicate people at the time understood and scholars now understand these manifestations of spiritual power primarily in individualistic terms, defining a religious tradition with adherent churches but at the same time highlighting their emphasis on personal religious experience. See Lippy, 43, 44; Charles H. Lippy, Being Religious, American Style: A History of Popular Religiosity in the United States (Westport, CT: Praeger, 1994), 167; Williams, 148; Deborah Vansau McCauley, Appalachian Mountain Religion: A History (Chicago: University of Illinois Press, 1995), 264; Troy D. Abell, Better Felt than Said: The Holiness-Pentecostal Experience in Southern Appalachia (Waco: Markham, 1982), 4-6, 148; and John D. Photiadis, ed. Religion in Appalachia: Theological, Social, and Psychological Dimensions and Correlates (Morgantown, WV: Center for Extension and Continuing Education, 1978). In Work and Life in the Kentucky Coal Fields, Richard Callahan departs from this interpretation somewhat, but he sees holiness/Pentecostal movements as seedbeds for union activism and industrial resistance, perhaps better examples of civil religion than of corporate Christian worship.
} 
self but of the group. Methodism continued to emphasize personal religious experience and the power of God in the life of an individual, but it balanced that with an absolute requirement of exercising these for the benefit of others as well, both within and without the walls of the institutional church. This is seen on a large scale in revivalism, which was still an accepted and expected practice in West Virginia at this time. By the Gilded Age, revivals had shed most if not all of the social and economic functions which they served during the antebellum era, especially in the frontier South. Even towards the end of the Second Great Awakening, in the North in particular, the emphasis on personal conversion, always an important factor in revivals, completely overshadowed any other reason for gathering. Methodists in West Virginia specifically banned alcohol, tobacco, worldly amusements, and Sunday excursionists from camp meetings. ${ }^{97}$ Furthermore, transportation improvements meant that protracted meetings no longer represented the primary presentation of organized religion to sizable portions of the population, as they had on the frontier.

Admonitions to repent, convert, and devote oneself to holy living typified protracted meetings before and after the Civil War. Whether it was any number of now-forgotten ministers in front of hundreds in a small town or D.L. Moody or Billy Sunday speaking to thousands in New York City or Chicago, coming to Jesus was the reason for such events. As Lippy puts it, this was the "privatization of religiosity." 98 The preacher wanted individual attendees to know that a direct relationship with God was possible immediately, and that said relationship came with a transforming and transcending power. These were leveling events in which any

\footnotetext{
${ }^{97}$ Williams, 114-115. See also Dickson D. Bruce, And They All Sang Hallelujah: Plain-folk Camp-meeting Religion, 1800-1845 (Knoxville: The University of Tennessee Press, 1981) and McCauley, Appalachian Mountain Religion, 264, 265, among many others. "Observance of the Sabbath," Official Journal of the West Virginia Annual Conference of the Methodist Episcopal Church, 1882, 36, 37; Burrows, et. al., 132.

${ }^{98}$ Lippy, Being Religious American Style, 109.
} 
distinction the world might esteem vanished. Race, gender, social standing, wealth, lineage, age, education, mental or physical ability - nothing could stand in the way of God working in the lives of those willing to be transformed and serve.

As Chapters 5 and 6 show, revivalism at this time and place was not unique to Methodists. Baptists and Presbyterians employed the mass gathering as well. Methodists, however, engaged in the activity much more frequently, as indicated by circuit/church and annual conference records. The conferences operated specific camp meeting grounds throughout the state, but most revivals occurred in local churches or in nearby lots or buildings. At times, the two denominations held joint revivals. ${ }^{99}$ Personal conversion still constituted the core of the revival experience. Every preacher hoped to increase the size of his congregation with souls he had won during the meeting.

However, the prevalence of these events, coupled with the descriptions of them from church records, indicates an increasing importance of revivals to those already belonging to the church. Participation in revivals was very much a demand placed on parishioners by the Methodist ecclesiastical structure. Members should attend to grow in holiness, and they should work with the pastor before the event to ensure its success. This planned spontaneity served as glue, binding the congregation together in a unique way. Thus, the revival, stripped of the games, races, dalliances, and business dealings so common in the early nineteenth century, truly became a rallying point for the local congregation. Individual speakers might bring a message of individual salvation for individual listeners, but it was ultimately for the purpose of building up the church. Those already believing would be called to renewed holiness for the purpose of

\footnotetext{
${ }^{99}$ Burrows, et. al., 132-135, 202; "Oakland District Report," Official Journal of the West Virginia Annual Conference of the Methodist Episcopal Church, 1885, 39; "District Superintendent's Report," 1906, 58; "District Report,"1914, 50; "Revival," Elk Garden News (Elk Garden, WV), Jan. 10, 1890; Dec. 19, 1890; Nov. 20, 1891; "The Campaign Begins Sunday Night 7 O'Clock," Keyser Daily News (Keyser, WV), Feb. 19, 1917; "Methodist Rally," The Elkins Inter-Mountain (Elkins, WV), Nov. 3, 1917.
} 
serving others. There were some joint revivals, but most were not cooperative affairs. New converts might be won, but they would give back to the whole later by preparing and participating in the next revival.

While revivalism displays popular religion, it also demonstrates West Virginia Methodism's deep connection to its heritage. To be sure, some of the trappings of awakenings had changed, but the substance remained. The emphasis on traditional revivalism did not lead to holiness and/or Pentecostalism, as some maintain it did elsewhere. On the other hand, a healthy dose of religious enthusiasm still seemed present at the time in West Virginia. An attendee of Methodist protracted meetings described the events as noisy, almost rowdy events, filled with shouting. The exuberance, however, was not caused by alcohol, games, or fighting. Rather, it came from overwhelming joy felt "[w] hen a church member gets warmed up and throws off all the cares of this world." Such a release caused a person to feel "like shouting . . because he is feeling good, and must shout or burst." ${ }^{\prime 100}$ In neighboring states and conferences, the revival, both in the camp meeting and in the church, was quickly being viewed with suspicion and derision, in large part due to the behavior detailed above, and was supplanted by a more social gospel-oriented approach which de-emphasized aggressive evangelization and called for individual salvation. ${ }^{101}$

The centrality of revivals, the various manifestations of popular religion, and the social composition of congregations in West Virginia between 1880 and 1920 combine to point to some important conclusions while at the same time raising additional questions. In this latter category,

\footnotetext{
100““Communicated,” Elk Garden News (Elk Garden, WV), June 19, 1891.

${ }^{101}$ N.B. Carrington, "Facing New Problems and Opportunities, 1915-1965," in Those Incredible Methodists: A History of the Baltimore Conference of the United Methodist Church, edited by Gordon Pratt Baker (Baltimore: Commission on Archives and History, 1972), 316, 317; L. Carroll Yingling, Jr., "A Century of Preachers and Conference Sessions, 1865-1915, in Those Incredible Methodists, 354, 355.
} 
for example, is the issue of the comparative success of the various branches. As stated, the MEC and the MECS achieved about the same amount of numerical success in the Alleghenies. However, in some particular cities and towns one branch did markedly better than the other. In Keyser, for example, the MECS was much larger than the MEC. In Elkins, those positions were reversed. In places such as Beverly and St. George, where the railroad either never came or came late, both branches fared about the same. Both Elkins and Keyser were major commercial centers along the WVC\&P, and the status of both Beverly and St. George declined, so location along the railroad does not seem to be a factor here. The exact role of class remains unclear as well. The MEC church in Keyser appeared to be solidly middle class, whereas the MECS congregation had a much higher working class contingent. On the other hand, both Elkins congregations were mostly working class.

One important factor could be war-time allegiances. Mineral (at the time part of Hampshire) and Pocahontas counties both strongly favored secession from the Union and the MECS was particularly strong in both places. Randolph County also supported Virginia's Ordinance of Session, but the MEC did better there than did its southern counterpart. Both branches fared about the same in Tucker County, which voted in favor of secession. The MEC did better in the mountainous western portion of Grant (which had been part of pro-Southern Hardy County), while Southern Methodists fared better in the lower elevations in the east, particularly around the county seat of Petersburg. ${ }^{102}$ Old political and sectional divisions could

\footnotetext{
${ }^{102}$ Richard O. Curry, A Study of Statehood Politics and the Cooperhead Movement in West Virginia (Pittsburgh: University of Pittsburgh Press, 1964), 141-149. The secession and statehood issues in what is now West Virginia were extremely complex and complete official voting records do not exist. However, evidence from letters, manuscripts, and newspapers from the period give a valid indication of secession's popularity in the various counties. For more on the subject see also, among others, Granville D. Hall, The Rending of Virginia: A History, Reprint (Knoxville: The University of Tennessee Press, 2000); Charles H. Ambler, The Makers of West Virginia and Their Work (Huntington, WV: Gentry Brothers, 1942); Charles H. Ambler, Sectionalism in Virginia, $2^{\text {nd }}$ ed. (Morgantown, WV: West Virginia University Press, 2008); Charles H. Ambler, Francis H. Pierpont, Union War Governor of Virginia and Father of West Virginia (Chapel Hill: The University of North Carolina Press, 1937); Richard O. Curry, “A Reappraisal
} 
help account for some later lingering religious divisions, but they don't seem to explain the situation entirely. Furthermore, there is no indication from any of the churches or denominational bodies in West Virginia during the Gilded Age and the Progressive Era of what specific roles these issues played in missionary affairs, especially later in the period. It may be best to avoid drawing harder conclusions about this issue based on former loyalties, as class and racial (or lack thereof) data do not seem to suggest any clear Union/Confederate fault lines in post-war church life in this part of state.

The social composition of the various circuits and churches does show that Methodism proved effective in ministering and appealing to people from all walks of life. The denomination remained faithful to its egalitarian roots by encouraging active participation and leadership among the lower ranks of society. At the same time, as the MEC congregation in Keyser and the MECS congregation in Marlinton demonstrate, the middle class could quickly come to dominate. This illustrates, at least in part, a phenomenon Wesleyan scholar Donald Dayton has dubbed "embourgeoisement," - the quest for greater respectability, whether economic, political, intellectual, or a combination, often at the expense of enthusiasm, vitality, and prophetic voice. ${ }^{103}$

It may be easy to see why this occurred in Keyser. The railroad had been part of its landscape since before the Civil War. By the early 1880s, the town stood at the crossroads of key rail lines extending in all directions, connecting Mineral County with Baltimore, Pittsburgh, and other major industrial cities. Commerce grew around burgeoning coal and transportation sectors. This environment provided fertile ground for a budding middle class.

of Statehood Politics in West Virginia," The Journal of Southern History 28, no. 4 (Nov., 1962) : 403-421; and George Ellis Moore, A Banner in the Hills: West Virginia's Statehood (New York: Appleton-Century-Crofts, 1963).

${ }^{103}$ Donald Dayton, “The Embourgeoisement of a Vision: Lament of a Radical Evangelical," The Other Side: Strength for the Journey 23, Vol. 8 (1987) : 19. 
On the other hand, embourgeoisement in Marlinton comes as more of a surprise. Of the county seats along the railroad, it was by far the least populated. Its economy, particularly the manufacturing, commercial, and financial sectors, as well as that of Pocahontas County in general, was much less developed than the other four counties examined here. Accordingly, the middle class would have been much less developed here than in Keyser. ${ }^{104}$ On the other hand, its logging industry was the largest in the state. Nevertheless, few industrial workers and their families belonged to the Marlinton MECS. Businessmen, professionals, and politicians dominated the group.

Echoing the theme of embourgeoisement, Hempton writes, "Methodism at its heart and center had always been a profoundly countercultural movement... It thrived on opposition."105 Methodism no doubt thrived in the Alleghenies, but it reflected a passive opposition at best. The middle class congregations in Keyser and Marlinton hardly suggest opposition to the new economic order. Even the many other circuits comprised largely of industrial workers did not serve as seedbeds for resistance movements such as labor unions. As the literature indicates, the workers in this region remained largely quiet throughout the Gilded Age and the Progressive Era (see Chapter 2). Furthermore, the frequent revivals and emphasis on traditional Wesleyan holiness did not spawn religious resistance/purity movements such as independent holiness and Pentecostal churches. In fact the, the bourgeois congregation in Marlinton exhibited significant interest in revivals well into the 1910s. It at least appears that, in this particular situation, social respectability did not preclude religious enthusiasm.

\footnotetext{
${ }^{104}$ Ronald L. Lewis, The Transforming the Appalachian Countryside: Railroads, Deforestation, and Social Change in West Virginia, 1880-1920 (Chapel Hill: The University of North Carolina Press, 1998), 199.

${ }^{105}$ Hempton, 201.
} 
As outlined, Methodism in the mountains showcased several manifestations of popular religion. Yet the several circuits never signaled any dissatisfaction with the episcopacy, the connectional system, or the theology/polity of the denomination. All the evidence suggests they were comfortable with the existing balance between the charge and the hierarchy, as well as the broad acceptance of moderate social positions and a mildly inclusive approach to doctrine (see Chapters 7 and 8).

In fact, Methodism in the Allegheny highlands seemed to typify this broad approach to the sectarian heritage by being able to encompass the social and economic complexity of the area and era while at the same time remaining true to those things which were vitally Methodist. It did, as Hempton points out, succeed in a place of transition and change. It did not, as perhaps Hempton's thesis might anticipate, constitute an openly and obviously oppositional force, in either the sacred or secular spheres. As portrayed throughout this work, mainline Protestantism and mainstream American culture reinforced each other to the point of blurring distinctions between the two. This is the point of the "embourgeoisement" thesis. Oppositional religion was no longer needed.

However, the secular sphere could encroach only so far. The large number of working class parishioners, coupled with the high rate of working class leadership, proves that this was not the church of industrialists in this region, or even of the middle class. At the very least, Methodism remained responsive to working class religious needs, despite the notable middle class presence in some cities and towns. Lower class parishioners did not allow themselves to be controlled by their social superiors. Even in the case of the Keyser MEC and the Marlinton MECS, the evidence suggests few members of the lower ranks of society attended the churches, 
not that the many were dominated by the few. ${ }^{106}$ What centralization did occur at the state and national levels did not come at the expense of operations at the local level nor did it limit lay involvement across the social spectrum.

West Virginia Methodism's continued reliance on lay ministry and leadership, along with the frequent use of mostly traditional revival practices, show that a solid sacred core remained at the heart of the MEC and MECS in the state. Statewide, both branches reacted with ambivalence to the changes and tensions accompanying industrialization, while in the mountains, neither held high the banner of resistance. Nevertheless, neither let the secular world alter its foundations or dictate its ministry (see also Chapters 7 and 8). ${ }^{107}$ These examples of popular religion suggest how and why Methodism thrived in the tumult of industrializing West Virginia (and why it did so well in so many similar situations throughout history). It consistently offered the least in society a place at the head of the table while simultaneously balancing the best of its traditions with the call to personal and collective spiritual renewal.

\footnotetext{
${ }^{106}$ The one possible exception to egalitarianism may be the Huntersville MECS, where professionals and merchants compromised most of the leadership of an agrarian congregation. However, census data indicates most of these farmers owned their own land and hired help. Thus, economically and socially they occupied a position roughly analogous to that of their white collar counterparts. They may have represented a different part of, or even type of, economy, but these farmers should not be considered working class. In any event, membership records are so scarce that drawing any hard conclusions remains difficult.

${ }^{107}$ Meitzen, 371, 372. For more on Protestant involvement in the West Virginia labor movement in general see Richard D. Lunt, Law and Order vs. The Miners: West Virginia, 1907-1933 (Hamden, CT: Archon Books, 1979). Such involvement was most common and conspicuous in the southern coalfields and Northern Panhandle.
} 
The Reformed Tradition

\section{5: Presbyterians}

After the Civil War, hard feelings persisted between the Presbyterian Church in the United States of America and the Presbyterian Church in the United States. Northern Presbyterians (PCUSA) wanted their Southern brethren (PCUS) to repent of their support of secession and of slavery. Since Northerners saw slavery and secession as the causes of the split in the church, they called into question the very existence of the Southern wing. With the source of disagreement gone, the division should heal.

Southern Presbyterians saw the situation differently. To be sure, slavery and secession were gone. Southerners believed other issues played a role in creating the rift in the church, and those preceded slavery and secession. The Civil War did not cause them; it simply brought them to the fore. Church polity represented a major, very broad factor. Dating back to the 1830 s, segments of the church disagreed on key issues of church governance, organization, and the powers of the General Assembly. ${ }^{1}$

Theological contentions also re-emerged. During the Second Great Awakening, New School clergy who supported the revivals equivocated on the traditional interpretation of election. The Westminster Confession, the Presbyterian statement of faith dating from 1647 and adopted by American Presbyterians in 1729, stated that " $[\mathrm{b}] \mathrm{y}$ the decree of God ... some men and angels are predestinated unto everlasting life, and others are foreordained to everlasting death."2 In short, God elected some people to go to heaven and others to go to hell (also called reprobation), and neither group of people could influence the matter in any way.

\footnotetext{
${ }^{1}$ James H. Smylie, A Brief History of the Presbyterians (Louisville: Geneva Press, 1996), 79, 80; Randall Balmer and John R. Fitzmier, The Presbyterians (London: Praeger, 1994), 66-72.

2“"The Westminster Confession of Faith, 1647," in The Creeds of Christendom: The Creeds of the Evangelical Protestant Churches, vol. 3, Philip Schaff, ed. (Grand Rapids: Baker Books, 2007).
} 
A strict interpretation of this idea clashed with the revival ethos of the New School. However, even when New School Presbyterians withdrew to form their own General Assembly in 1838 , they did not officially modify the doctrine. Some preachers and theologians re-worked the concept in light of revivalism or shied away from it altogether, but at least the New and Old School agreed on the doctrine of election. ${ }^{3}$ The Civil War healed the Old/New split, but created a geographical schism.

While a second denominational split was not predicated on doctrine, by the end of the nineteenth century Northern and Southern Presbyterians were clearly on different theological trajectories. In 1903, Northern Presbyterians voted to modify their doctrinal statement, the Westminster Confession of Faith. The doctrine of election received substantial modification. They eliminated the concept of reprobation completely, replacing it with language affirming that God offered salvation freely to all people. The doctrine relating to non-elect infants, which taught that non-elect babies who died went to hell, was also deleted. The PCUSA believed that those who died in infancy were saved and went to heaven. ${ }^{4}$

Southern Presbyterians denounced these changes. The PCUS rejected what is considered "new theology" and declared it had no place in their seminaries. It proved extremely resistant to amending the Westminster Confession, especially on issues that involved the sovereignty of God. To be clear, however, Southern Presbyterians did not completely disagree with all the conclusions reached by their Northern counterparts. Denominational scholar Ernest Thrice Thompson observes that "few Presbyterians, if any" believed the non-elect who died in infancy

\footnotetext{
${ }^{3}$ William Adams Brown, "Changes in the Theology of American Presbyterianism," The American Journal of Theology 10 (July 1906) : 398; Randall Balmer and John R. Fitzmier, The Presbyterians (Westport, CT: Praeger, 1994), 47, 48; C.C. Goen, Broken Churches, Broken Nation: Denominational Schisms and the Coming of the Civil War (Macon: Mercer University Press, 1985), 68-70; S. Donald Fortson III, "New School Calvinism and the Presbyterian Creed," The Journal of Presbyterian History 82 (Winter 2004) : 221, 222.

${ }^{4}$ Smylie, 106; Brown, 410.
} 
spent eternity in hell. Southern Presbyterians held that the Confession was silent on this matter because the Bible was silent on the matter. Thus, no changes were necessary and anything indicating otherwise might be used to misconstrue other areas of the Confession. ${ }^{5}$

Another classic Presbyterian doctrine, the spirituality of the church, also proved factious. During the antebellum period, American Presbyterians strengthened and refined this concept. The Old School (those who did not support the Second Great Awakening), which dominated in the South, became a staunch defender of this idea, and it became a distinctive feature of the Southern church before and after the war. As articulated by the Old School General Assembly in 1845 , the concept of the spirituality of the church held that the "church of Christ is a spiritual body, whose jurisdiction extends only to the religious faith and moral conduct of her members."

Slavery forced these issues together, as Old Schoolers deemed any stance on slavery which promoted governmental coercion one way or the other was inappropriate. Individual congregants were free to believe and act as they chose, but the General Assembly could make no official pronouncements. ${ }^{7}$ To Southerners, the formation of the Presbyterian Church in the

${ }^{5}$ Ernest Thrice Thompson, Presbyterians in the South, Volume 3: 1890-1972 (Richmond: John Knox Press, 1973), 219-222.

${ }^{6}$ Goen, 164, 165 .

${ }^{7}$ In the context of the spirituality of the church, Southern Presbyterians argued that Christian slaveholders had a duty to God, country, and their slaves to treat those slaves according to biblical precepts. In that sense, slavery was a moral issue and members of the General Assembly and leading theologians felt that they were well within their authority to urge slaveholding parishioners to treat slaves well. However, because slavery was an institution that contributed to the very fabric of a Christian society, it was also a social and political issue. Furthermore, because the Bible never explicitly condemned slavery, the church could not either. Abolition must be resisted because it sought to undermine the God-ordained order and undermine the Bible. On the other hand, Southern Presbyterians would never argue that the government should mandate that ALL white men should own slaves. That, too, was not part of the biblical order. In short, Southern Presbyterians wanted the state to preserve the social status quo while the church would improve the moral quality of slaveholders, and by extension the moral quality and economic utility of slaves. The one major exception to this stance was in Kentucky, where Presbyterians led a failed attempt to pass a gradual emancipation amendment to the state constitution. See Thompson, Prebyterians in the South: Vol. 1: 16071861, 532-537 and Presbyterians in the South, Volume 2: 1861-1890 (Richmond: John Knox Press, 1972), 58-62; Eugene D. Genovese, The Slaveholders'Dilemma: Freedom and Progress in Southern Conservative Thought, 18201860 (Columbia: University of South Carolina Press, 1992), 58-61; Consuming Fire: The Fall of the Confederacy in the Mind of the White Christian South (Athens: University of Georgia Press, 2009), 105-107; Elizabeth Fox- 
Confederate States of America (which became the PCUS after the War) in the wake of Secession resulted as much from Northern Old Schoolers' willingness to violate the now sacred principle of the spirituality of the church as it did from the Southern states' decisions to secede. ${ }^{8}$ While the War ended slavery and secession, it could not eradicate true religion, and Southern Presbyterians clung to their independence with even greater tenacity.

In the latter half of the nineteenth century, Southern Presbyterians still believed their Northern counterparts failed to adhere fully to the critical doctrine of the spirituality of the church. Meanwhile, as scholar Marthame Sanders points out, "In the 1890s and early 1900s, the PCUS stood proudly on its foundation of the spirituality of the church." ${ }^{\prime 9}$ Fidelity to this particular doctrine shaped Southern Presbyterian responses to emerging social issues, ensuring a conservative, at times almost reactionary, response to many industrial age circumstances. In the Allegheny Mountains of West Virginia, many new industrial elites found this theological and social traditionalism to their liking. They exercised considerable influence in the church into the twentieth century, as Old School/Old South theology remained the rule of faith in the state. Despite a congregational yet moderately authoritarian church polity and little willingness to become involved in social issues, members of the commercial and industrial working and middle classes also joined Presbyterian churches in large numbers. Thus, although the denomination became, in some ways, the church of industrialists in the region, it still exhibited elements of popular religion and maintained its mass appeal.

Other issues continued to divide North and South. The two sides also continued to

Genovese and Eugene D. Genovese, The Mind of the Master Class: History and Faith in the Southern Slaveholders' Worldview (New York: Cambridge University Press, 2005), 622, 623.

${ }^{8}$ Marthame E. Sanders III, “ “A Fellowship of Concern' and the Declining Doctrine of the Spirituality of the Church in the United States," The Presbyterian Journal of History 75 (Fall 1997) : 180.

${ }^{9}$ Sanders, 180 . 
disagree on a wide array of polity and governance matters. By themselves, they were almost negligible, but, taken together, these issues constituted another stumbling block on the road to reunion. There were many controversial matters, most of which had little to no bearing on the development of Presbyterianism in West Virginia at this time, including the dispute over the doctrine of election. However, one topic in particular, which by itself played a minor role in North/South relations nationally but which had a tremendous impact on West Virginia Presbyterianism, concerned missions. Both sides equally championed missions, but disagreed on what level of the denominational structure held the primary responsibility for organizing missionary endeavors.

Prior to the Civil War, Presbyterians vested individual presbyteries with the authority to launch and oversee missions. Synods at times provided some general financial support, with the General Assembly simply recording all of the various evangelistic efforts. ${ }^{10}$ Shortly after the War, Northern Presbyterians began to centralize missionary activity, creating an active missions arm at the national level. At its inception in 1870, the Board of Home Missions bore the responsibility of supporting "feeble churches," not missionaries. ${ }^{11}$ By mid-decade, however, the General Assembly commissioned the board to direct and coordinate evangelistic work across the denomination. The increased activity of other Protestant groups, as well as the rapid expanse of railroads and growth of cities, prompted the concentration of denominational missionary efforts

\footnotetext{
${ }^{10}$ Presbyteries were the unit of church government immediately above the local congregation. Presbyteries usually consisted of all Presbyterian churches in a particular group of contiguous counties. Synods were the unit of church government immediately above the presbytery. Several presbyteries comprised a synod, which usually covered an entire state. More detail is given on both of these below.

11“Annual Report on Home Missions of the Presbyterian Church in the United States of America," Minutes of the General Assembly of the Presbyterian Church in the United States of America, 1871, 647.
} 
under a single jurisdiction. ${ }^{12}$ The newly-empowered board sent laborers into a variety of fields. Despite the continuing denominational split, Northern Presbyterians pressed into the south, working with both blacks and whites. The home mission board identified the mountain South as a region with unique needs distinct from those of the Cotton Belt.

Appalachian scholar Henry D. Shapiro observes that this "discovery of Appalachia” coincided with the emergence of local color literature on the area. The two discoveries were not causally connected, but the local color movement helped shape the opinion of missionaries and denominational leaders. Appalachia was not just spiritually destitute; it was culturally destitute as well. Mission work then, was not just spiritually uplifting; it was also culturally uplifting, because the church constituted a great bulwark of American civilization. ${ }^{13}$

Thus, over the last quarter of the nineteenth century, the PCUSA sent dozens of missionaries into the mountain South. Tennessee and Kentucky received the overwhelming majority, peaking at twenty-nine and twenty-three respectively, in 1895. Virginia and North Carolina consistently had a few, but never more than four each. Seventeen missionaries labored in West Virginia in 1875, far more than any other state at the time. However, within a decade that number declined to eleven, and then quickly thereafter fell to four, and then to zero by the turn of the century. ${ }^{14}$ The steady decline in PCUSA missionaries in West Virginia from the mid1880s onward probably resulted from agreements between the Synod of West Virginia (PCUSA) and the Synod of Virginia (PCUS). In 1889, the two bodies, both occupying parts of West

\footnotetext{
12،Annual Report on Home Missions of the Presbyterian Church in the United States of America," Minutes of the General Assembly of the Presbyterian Church in the United States of America, 1872, 135; 1874, 24; $1878,107-108$.

${ }^{13}$ Henry D. Shapiro, Appalachia On Our Mind: The Southern Mountains and Mountaineers in the American Consciousness, 1870-1920 (Chapel Hill: The University of North Carolina Press, 1978), 57

14، Annual Report of the Board of Missions of the Presbyterian Church in the United States of America," Minutes of the General Assembly of the Presbyterian Church in the United States of America, 1875, 591; 1885, 74; 1890, 11; $1895,51,1901,23$.
} 
Virginia, agreed that neither would encroach on the other's territory. Thus, the Northern

Presbyterians remained confined to the Northern and Northwestern parts of the state, with the Baltimore and Ohio mainline providing an approximate boundary. Their Southern brethren retained control over the Eastern Panhandle and much of the rest of state. Both sides renewed the agreement in $1905 .{ }^{15}$

As Presbyterians and many other Protestants saw it, education formed another vital element of American society. Thus, schools became a necessity. Between 1885 and 1905, Northern Presbyterians established sixty-four schools in the mountains. The Board of Home Missions oversaw all of them, although many were directly founded by groups of believers at the state and local levels, many of which were women's groups. ${ }^{16}$

The basic theme distilled from this narrative of religious encounter was one of “otherness." Elizabeth Hooker argued that residents of the Southern mountains viewed both major branches of Presbyterianism as "foreign" because they had "few or no indigenous churches in typically Highland territory." Furthermore, each regarded the region as a mission field. ${ }^{17}$ This understanding persisted in the field of Appalachian religion, and the prevailing perception remains that Presbyterian churches in the area existed almost exclusively in the wider valleys and broader towns. The rural districts and higher elevations contained a mere handful of congregations, most of which were mission churches. ${ }^{18}$

\footnotetext{
${ }^{15}$ "The Joint Committees on Co-operation in Home Mission Work of the Synods of West Virginia and Virginia," Minutes of the Synod of Virginia, 1905, 79, 80. For a detailed discussion on Northern Presbyterian activity in West Virginia at this time, see Gill I. Wilson, The Story of Presbyterianism in West Virginia (s.l.: s.n., 1958).

${ }^{16}$ Shapiro, 54, 55.

${ }^{17}$ Elizabeth Hooker, Religion in the Highlands: Native Churches and Missionary Enterprise in the Southern Mountain Area (New York: Home Mission Council, 1933), 217.

${ }^{18}$ Deborah Vansau McCauley, Appalachian Mountain Religion: A History (Chicago: University of Illinois Press, 1995), 370.
} 
Such a conclusion understandably followed from the Northern Presbyterian perspective and situation. Denominational schisms effectively relegated the PCUSA to outsider status in Southern Appalachia. While they still maintained a toehold in West Virginia, Northern Presbyterians in West Virginia viewed the eastern and southern portions of the state as a mission field for which they bore primary responsibility. In apparent defiance of the agreement between the Synod of West Virginia and the Synod of Virginia, the former organized, with varying degrees of success, mission churches and Sunday Schools in the coal counties. ${ }^{19}$

As the Synod of Virginia understood it, that territory belonged to the Greenbrier Presbytery, and which was more than capable of evangelizing the area. Presbyterianism was not a foreign entity in the mountains of West Virginia. Southern Presbyterianism remained firmly entrenched in all parts of Appalachia. Southern ecclesiastical activity in the mountains of West Virginia during the Gilded Age and Progressive Era demonstrated this fact and offered a contrasting narrative to the prevailing story of difference and highly centralized religious authority.

\section{Expansion in the Mountains: Tradition and Progress}

Regarding missions, Southern Presbyterians differed from their Northern counterparts in two important ways. First, of course, the PCUS did not "discover" Appalachia after the Civil War. The PCUS was the only Presbyterian church in the mountain counties of West Virginia, maintaining a notable presence in the region dating to the American Revolution. Thus, mission work revolved primarily around using the transportation and industrial advances in the region to strengthen an existing community of churches, not plant new ones. The church did see the mountains as a mission field, but only because its members saw new people coming into their

\footnotetext{
${ }^{19}$ Gill I. Wilson, The Story of Presbyterianism in West Virginia (s.1.: s.n., 1958), 76-82.
} 
communities and counties who needed the gospel. If anyone was "the other," it was the Northerners, not the Presbyterians attending churches that dated back generations.

Second, in contrast to their Northern counterparts, Southern Presbyterians retained their traditional decentralized approach to mission work. In 1866, the PCUS General Assembly adopted home mission plans. The Optional Plan allowed presbyteries to keep and manage all home mission funds as long as some money was given to the General Assembly's executive committee. The Preferred Plan, which nearly all presbyteries came to follow, called for all presbyteries to send all home mission funds to the executive committee. Those funds were then distributed to presbyteries according to their needs. As Thompson notes, "In practice this meant that each presbytery was allowed to, and often did, draw out as much as its churches contributed." 20

This meant that throughout the Gilded Age, the presbyteries remained largely responsible for missions. When rapid population growth prompted changes, most synods took only small steps toward increasing their roles in evangelization. Many believed the synod possessed no authority to engage directly in missionary endeavors, and the General Assembly placed no such obligations on them. ${ }^{21}$ In most cases, synodical mission boards had comparatively little power and few resources. They functioned mostly in a complementary fashion, usually just dispensing funds. The major exception to this rule in the last quarter of the nineteenth century was in the Synod of Kentucky. In 1881, it appointed Edward O. Guerrant as synodical evangelist, in charge of coordinating and directing the missionary efforts of the various presbyteries. In this case, the synod took on a leadership role. It maintained that the changing times, increased population, and

\footnotetext{
${ }^{20}$ Thompson, Presbyterians in the South, Vol. $2,29$.

${ }^{21}$ Thompson, Presbyterians in the South, Vol. 2, 28.
} 
industrialization required greater centralization of missionary work. ${ }^{22}$

The rest of the PCUS believed the presbyteries remained up to the evangelistic task. The presbyteries belonging to the Synod of Virginia demonstrated this commitment to traditional Presbyterian polity. The three presbyteries serving the mountain counties of West Virginia - the Winchester, the Lexington, and the Greenbrier - all remained confident that they could effectively minister to the increasing population in the mountains. Each had a home mission committee responsible for identifying new mission fields within the bounds of the presbytery, establishing and caring for new churches, and filling vacant pulpits. Pastors of existing churches often took the lead in creating new churches. The presbyteries also had a handful of at-large evangelists to help with this process, as well as to help care for destitute areas. The synod regularly supplied some funding, but the presbyteries bore almost all of the responsibility for initiating and administering mission work. ${ }^{23}$

A home mission committee founded churches in one of two related ways. First, after confirming that a particular area needed a church, it formed a commission to establish a new congregation in a certain location in that field, usually in a new town. In most cases, an evangelist led the commission, which often consisted of leaders from churches willing to relocate in order to help lead the new congregation. A meeting, although not necessarily a revival or protracted meeting, was held to identify any Presbyterians in the town and unite them with the new church. When not establishing new churches, evangelists temporarily filled empty pulpits and otherwise ministered to struggling congregations. ${ }^{24}$

\footnotetext{
${ }^{22}$ H. Davis Yevell, Moving Mountains: A History of Presbyterian and Reformed Faith at Work in Appalachia (Amesville, OH: Coalition for Appalachian Ministry, 1985), 19.

23،"Home Mission Committee Report," Minutes of Winchester Presbytery, 1886, 101.

24،"Home Mission Committee Report,” Minutes of Winchester Presbytery, 1886, 101.
} 
The impetus to form a new church did not always come from the presbytery. The second way in which one could be established was by a request from a group of parishioners. This almost always occurred when a new town formed. Presbyterians moving into a new community had to petition the presbytery for permission to formally organize a church. After evaluating the request, the home mission committee would dispatch a commission to form the new church. ${ }^{25}$ Thus, in both scenarios the presbytery had to recognize the church after approving the report from the commission.

The advent of the railroad sparked renewed Presbyterian growth. When the General Assembly convened in 1880, the five mountain counties studied here reported fourteen churches - four in Mineral, one in Grant, one in Tucker, four in Randolph, and four in Pocahontas. Some of these congregations were older than others, but overall the denomination maintained a good presence in the area. Most of the churches were located in larger towns, but a few served extensive rural districts. They served existing communities well, but new ones would be needed to serve new towns and an increasing population. The existing Presbyterian presence, coupled with a willingness to use the railroad, meant that Presbyterianism would soon come to most major towns along the West Virginia Central and Pittsburg mainline. It also meant the denomination would spread quickly into the backwoods as well. ${ }^{26}$

Presbyterian missions and growth in this region demonstrated not just a concerted effort to adhere to traditional church polity and evangelistic organization; they also highlighted the relationship between secular and sacred in an industrializing Appalachia. Deborah McCauley

\footnotetext{
25“"Church at Marlin's Bottom," Minutes of the Greenbrier Presbytery, 1880, 176.

${ }^{26}$ According to the records of the General Assembly, there were 10,243 Southern Presbyterians in the entire state of West Virginia. See "Statistics," Minutes of the General Assembly of the Presbyterian Church of the United States, 1880, 311-318. By contrast there were just 1953 members of the Presbyterian Church of the United States of America (Northern Presbyterians). See "Statistics," Minutes of the General Assembly of the Presbyterian Church of the United States of America, 1880, 427-430.
} 
posits that Methodists symbolized the new industrial order in Appalachia. "The Methodist church became the church of the industrialists in Appalachia," she argues. While large numbers of the middle and working classes joined Methodist ranks, "the powers that be found Methodism amenable to their values and worldview.",27

This was certainly true in many places. However, in the timber counties of West Virginia, if any church best suited the needs of the new power elite, it was the Presbyterian Church. People of all classes considered themselves part of this community, and denominational doctrine and polity contained enough elements of popular religiosity that people of all classes were, in some places, able to exercise some power in local churches. Nevertheless, Presbyterianism appeared particularly attractive to capitalists in the Alleghenies. In fact, throughout the South, "it was recognized ... as a well-to-do church." 28 No piece of evidence really explains why this was so in the mountains. In some cases, such as Henry Gassaway Davis, businessmen were Presbyterian long before they became wealthy. It could be also that certain doctrines appealed to others.

Of the three largest Protestant denominations, Methodists, with their episcopal system, had the most hierarchical church polity. Congregational autonomy was limited and bishops and presiding elders possessed strong executive power. ${ }^{29}$ Presbyterian polity created a multi-layered denominational edifice that left individual congregations with much autonomy. However, the upper levels of that structure (General Assembly, Synod, and Presbytery) enforced strict doctrinal conformity and once elected, local church leaders wielded a considerable amount of authority.

\footnotetext{
${ }^{27}$ Deborah Vansau McCauley, “Appalachian Mountain Religion, A History (Chicago: University of Illinois Press, 1995), 239.

${ }^{28}$ Thompson, Presbyterians in the South, Vol. 2, 286.

${ }^{29}$ For more on Methodist polity, see Chapter 4.
} 
Presbyterian polity details changed somewhat over the course of American history, and Northern and Southern bodies disagreed on some finer points. At the end of the nineteenth century, the basic structure of the Presbyterian system looked much as it had in the early eighteenth century, when American Presbyterians first began to organize beyond the local church. Presbyterians sought to maintain order, discipline, and authority, but those did not necessarily translate into concentrated power. They divided up authority among various denominational levels, thus preserving order but not giving too much power to any one person or group. The Southern church maintained greater decentralization than its Northern counterparts, which meant it left more authority in the hands of individual congregations and presbyteries, which consisted of a number of congregations in a relatively small geographical area. ${ }^{30}$

Local churches could choose clerical and lay leaders (such as ruling elders and deacons), but after voting on the ruling elders, the congregation delegated its authority to vote on other matters to these elected representatives. Thus, the rank-and-file membership had little authority or responsibility beyond voting for church leaders. Only the presbytery had the authority to ordain and install ministers in local churches. The synod, which by the nineteenth century usually included an entire state (or states in the case of Virginia and West Virginia), functioned primarily in judicatory and administrative roles. Synodical meetings included all the ministers in the presbytery and a ruling elder from each church. Participants elected a moderator and a clerk from among their own ranks. Synods coordinated relationships among the various presbyteries and between the presbyteries and the General Assembly. They also settled disputes between presbyteries and served as fora for constituent members to discuss doctrinal issues. Ultimately, they sent doctrinal questions to the General Assembly, which was required to poll the

\footnotetext{
${ }^{30}$ Lefferts A. Loetscher, A Brief History of the Presbyterians (Philadelphia: Westminster Press, 1978), 107, 108.
} 
presbyteries in order to make any changes to the Westminster Confession. ${ }^{31}$

The General Assembly operated in a similar fashion to the synod. In keeping with emphases of order and authority, the presbyteries, not the synods, elected the ministers and elders to attend national meetings. The national body bore responsibility for ensuring the health and welfare of the denomination as a whole. It mediated disputes and either upheld or overturned decisions from lower courts. Technically, its authority to legislate and make unilateral decisions was limited. The ability to discipline wayward clergy flowed from the synods and presbyteries represented in the General Assembly. ${ }^{32}$

The denominational apparatus contained multiple layers, each with varying levels of authority. The individual congregation and the presbytery exercised remarkable degrees of autonomy from more distant centers of power. Within these levels, and, in fact, at all levels, most of the power remained in the hands of ruling elders and ordained clergy. Thus, the ability of the rank-and-file member to exercise leadership on a regular basis was severely limited. While the Methodists did have a more hierarchical denominational structure, they also had numerous leadership and ministry positions open to members at the local level. Presbyterians had three opportunities - as ruling elders, deacons, and trustees. Some local churches, however, combined all three offices for a time, with the elders also serving as deacons and trustees.

Given the structure of the Presbyterian denomination and its emphasis on order and authority, it is possible to see how the industrialist class as a whole might have preferred that denomination. Presbyterians enjoyed no greater standing in the secular sphere than any other religious group. However, they embodied some of the values industrialists cherished - order,

\footnotetext{
${ }^{31}$ Smylie, 63, 64; T.P. Allen, The West Virginia Hills: A Study of the Work of the Presbyterian Church in the United States in the Synod of West Virginia (St. Louis: Buxton \& Skinnery, 1927), 21, 22.

${ }^{32}$ Smylie, 63.
} 
authority, and an understanding that the sacred and secular spheres were distinct but intertwined. Each of these characteristics of a Victorian values system closely linked with industrialization; proponents of each wanted to unify the country economically and culturally in the wake of a Civil War which politically united the nation but still left deep divisions. ${ }^{33}$ Furthermore, in an era when the secular became increasingly dominant, but still used the language of the sacred to accomplish its goals, a denomination committed to maintaining the boundary between the two spheres could have been appealing to those wishing to assert the prominence of the secular over the sacred.

History constituted another reason why Presbyterianism became the religion of the industrialists in the Alleghenies. While not the most numerous group, in some communities it was the oldest church, predating Methodism by a decade or more. Throughout much of the Allegheny region it arrived at about the same time as Methodism. Thus, many of the preindustrial elites also belonged to the Presbyterian Church, giving it an advantage at the dawn of the Gilded Age.

The pre-existing presence of Presbyterianism in the mountains, coupled with the fact that the churches were affiliated with the PCUS, also meant that the denomination remained theologically conservative in West Virginia in general and in the Allegheny counties in particular. Ironically the church of such Old South stalwarts as James Henry Thornwell, Benjamin Morgan Palmer, Robert Lewis Dabney, and John Girardeau was becoming the church of the captains of

\footnotetext{
${ }^{33}$ Robert H. Wiebe, The Search for Order 1877-1920 (New York: Hill and Wang, 1967), 145-147; John C. Hennen, The Americanization of West Virginia: Creating a Modern Industrial State, 1916-1925 (Lexington, University of Kentucky Press, 1996), 4; Nina Silber, The Romance of Reunion: Northerners and the South, 1865-1900 (Chapel Hill: The University of North Carolina Press, 1993), 95, 96.
} 
industry in what was once part of the Old Dominion, keystone of the Confederacy. ${ }^{34}$ The very industrial order these men and many others once questioned now fit comfortably within confines of traditional Southern Presbyterian orthodoxy. During the Gilded Age and the Progressive Era, the shift from an agrarian to an industrial perspective did not jeopardize or challenge historical doctrine or polity positions.

It should come as no surprise that this shift took place in West Virginia, which hooked its yoke to the industrial, free-labor North and tried to get a head start in the New South effort to "out Yankee the Yankees." 35 It is perhaps more surprising that, in the middle of an industrial revolution, the Southern Presbyterian church in the mountains of West Virginia retained its theologically conservative moorings. The fact that West Virginia churches remained under the ecclesiastical authority of the Synod of Virginia until well into the Progressive Era probably constituted the single greatest reason for the continued orthodoxy. While local congregations accepted the faith once received, the presbyteries and the synod, both of which were often run from Virginia, ensured that local pastors upheld the religious standards as well. Thus, the Dabney wing of the church still exerted considerable control over matters of faith and practice.

Antebellum Southern Old Schoolers put considerable effort into developing an understanding of the spirituality of the church, applying it most frequently to the issue of slavery. The fall of slavery did not mean the doctrine of the spirituality of the church was abandoned. To theologians such as Dabney, the slavery issue was just one of many issues. Since the spirituality of the church defined the actions of the church, the individual, and the state, that doctrine served

\footnotetext{
${ }^{34}$ See James Oscar Farmer, Jr., The Metaphysical Confederacy: James Henry Thornwell and the Synthesis of Southern Values (Macon: Mercer University Press, 1986) for more on the important role Southern Presbyterians in particular played in forming a Southern intellectual culture before the Civil War.

${ }^{35}$ From a speech by Henry Watterson delivered in New York, quoted in New York Tribune, November 21, 1877.
} 
as the lens through which to view all social and political interactions. Despite Dabney's social conservatism, he steadfastly maintained the church's sole task was to deliver the gospel to humanity. Anything else would supersede the authority given to it by God and encroach upon the divinely-ordained boundaries around other areas of life. ${ }^{36}$

This understanding persisted among Southern Presbyterians in Virginia and West Virginia into the Gilded Age and Progressive Era. A synodical resolution passed in 1910 reveals the centrality of their understanding of the church. The church's mission formed the basis of any kind of inter-denominational cooperation. The church was the body of Christ, and the Master commanded unity in it. The Synod argued, however, that this unity was not external but internal - "a spiritual unity, of love and sympathy and of effort to win the world to Christ." ${ }^{37}$ This spiritual unity could be achieved, despite widely differing doctrinal beliefs, by focusing on those things which all the churches held in common. As Presbyterians understood it, the great commonality was "the salvation of men." Thus, they could cooperate with all groups desiring to do this, but any plan of cooperation that infringed upon denominational beliefs would be unacceptable. Southern Presbyterians wanted to maintain their theological distinctives without the threat of external pressure to change those beliefs. ${ }^{38}$

Furthermore, PCUS members in West Virginia and Virginia continued to interpret the doctrine of the spirituality of the church in terms of a separation of church and state. This did not aim to prevent individual believers from using religion as a guide for their behavior and actions in the public sphere. Rather, it sought to keep the church out of the affairs of the state, and vice

\footnotetext{
${ }^{36}$ Sean Michael Lewis, Robert Lewis Dabney: A Southern Presbyterian Life (Phillipsburg, NJ: P\&R Publishing Company, 2005), 240, 241.

${ }^{37}$ Minutes of the Synod of Virginia, 1910, 52.

${ }^{38}$ Minutes of the Synod of Virginia, 52.
} 
versa. As a 1905 statement on Sabbath observance explained, in part:

while the church may use moral suasion with corporations and individuals, and should so educate its own members in civic righteousness that acting as citizens they will singly and collectively strive to secure the adoption and enforcement of righteous laws, yet ecclesiastical bodies, as such, should never take the sword into their hands, or directly employ or influence agencies of the State for the promotion of moral or spiritual ends. ${ }^{39}$

In keeping with the maintenance of proper order, both secular and sacred, Virginia and West Virginia Southern Presbyterians staunchly defended traditional gender roles in the church and in society. Church polity permitted only men to serve as elders, deacons, and trustees. Furthermore, the practice of forming churches by sending out commissioners from the presbytery and existing churches helped reinforce orthodoxy in all areas. Men tested and grounded in the faith bore the responsibility of organizing new churches. This increased the likelihood that new churches would be formed in the image of old ones.

The presbyteries and the Synod also worked to ensure that other traditional understandings of the Bible remained secure in a rapidly changing world. In 1899, the Synod of Virginia released a lengthy report on women in the church. At nearly fifteen pages long, the "Report on the Sphere and Rights of Women in the Church" offered detailed exegeses of Old and New Testament passages on the subject. At times even analyzing the Bible's original languages, the drafting committee sought to confront the "rapid and alarming development of the Woman's Movement" with a "full and plain statement of the teaching of the Word of God." 40

As these Southern Presbyterians saw it, the guiding Scriptural principle regarding women in the church and in the home was subordination. This did not make women inferior to men. Women were worthy to receive love, honor, and admiration, but God had placed them under the

\footnotetext{
39،"Sabbath Observance By Railroads," Minutes of the Synod of Virginia, 1905, 91.

40،Report on the Sphere and Rights of Woman in the Church," Minutes of the Synod of Virginia, $1899,121$.
} 
care and protection of men. Any abuse, coercion, or other mistreatment of women arising from this arrangement were the product of sin and not part of God's plan. In fact, the committee maintained, God had given men and women authority over different spheres of life. "The family is by the Scriptures made the special sphere of woman. There is her true throne ... and there is exercised her wisest dominion," the report affirmed. ${ }^{41}$

The Bible specifically forbade women from holding office or exercising authority in the church. Interpreting the Pauline epistles literally, this meant women could not serve as ministers, elders, or deacons. They could not lead worship services or preach or teach the Word of God to the assembled faithful. The Scriptures did provide for, or at least did not expressly prohibit, women to serve in some capacity. They could sing in the choir; they could form prayer circles; they could form missionary societies and other auxiliary groups; and they could teach in their own homes and in Sunday Schools. ${ }^{42}$

The report concluded by connecting these teachings to the overarching principle of subordination in the church, in the home, and in society. Without going into specifics, society in general must in some way be organized according to some conception of subordination. Women, by God's design, had their sphere, their strengths, their duties. Men, likewise, had theirs. If the two groups struggled against this plan and each other, individuals and society would suffer. If they cooperated in love according to God's plan, men and women, as well as society as a whole, would be lifted to "a higher and nobler life.",43

\section{Mainstream Growth Along The Mainline}

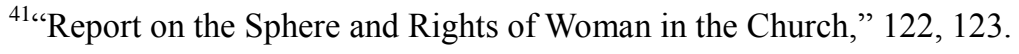

42،"Report of the Sphere and Rights of Woman in the Church," 123, 124, 132, 133.

43،"Report of the Sphere and Rights of Woman in the Church," 133.
} 
The shift that occurred in the mountains, then, was one of form, not of substance. The Southern Presbyterian church maintained its traditional theology and even associated directly with industrialization in some key locations. It is perhaps fitting then, that Henry Gassaway Davis played a role in the early history of Presbyterianism in the mountains. Although he featured far more prominently in the secular sphere, his involvement in the sacred sphere began before the war, about the time he took over the Piedmont terminal of the B\&O and opened his own business with his brothers in the early 1850s. Before the war they had branched out into banking and timbering. ${ }^{44}$

When Davis came to Piedmont as a superintendent for the B\&O, the town consisted of a handful of homes. A mere speck on the map, previously called Mount Carbon, it never rivaled the terminal cities of Parkersburg and Wheeling. ${ }^{45}$ However, Piedmont did experience modest growth in the late nineteenth century, becoming the first of a chain of industrial towns and small cities running through the Alleghenies that linked the mountains of West Virginia to larger Eastern and Midwestern manufacturing and trading centers. Shortly after his arrival, Davis joined the Piedmont Presbyterian Church, the oldest church in community, which had formed in 1854. By the following year, Davis had become a trustee. The original congregation of twentyfive consisted mostly of farmers, with a sprinkling of people from the professional and managerial classes. $^{46}$

\footnotetext{
${ }^{44}$ Thomas Richard Ross, Henry Gassaway Davis: An Old Fashioned Biography (Parsons, WV: McClain Printing Company), 1994), 25, 26.

${ }^{45}$ Ross, 25.

${ }^{46}$ Paul A. Smith, One Hundred Fifty Years of God's Bounteous Blessings: The History of Piedmont Presbyterian Church, 1856-2006 (Piedmont, WV: Self Published Church History, 2006), 1. The oldest church in the county was the Patterson's Creek congregation, located northeast of Keyser and just south of Cumberland, MD. It was chartered in 1768, with a second one established in 1834. Two other churches grew out of this original congregation, one in Burlington, also in Mineral County, and the other in Scherr, located in Grant County. These daughter congregations demonstrate the home missions initiatives undertaken by local congregations. A distance of forty-two miles
} 
The congregation suffered greatly during the Civil War, nearly dissolving shortly after the conflict ended. The church had no pastor and no elders for about eighteen months in the mid1860s. Seven members persevered, and the church reformed in 1868 . The new elders, one a dry goods merchant and the other a railroad agent, represented the commercial and industrial middle class. By 1880, the church had eighty members, a balanced mix of farmers, laborers, craftsmen, managers, and mid-level railroad officials. ${ }^{47}$

By then Davis had left the church - and West Virginia. He maintained a voting residence in Piedmont, but usually spent less than a combined three weeks a year there. He spent most of the warm months at his new residence of Deer Park, high in the Allegheny Mountains in Garrett County, Maryland. The family wintered in Frederick, Washington, D.C, or Baltimore. ${ }^{48}$ Piedmont remained the center of his industrial empire, but the church maintained its diverse social composition, attracting middle class professionals, coal miners, and mill workers. It had few socially prominent members. The most distinguished were perhaps Thomas B. Davis (Henry G.'s brother) and T.E. McCoole. Both men represented Mineral County in the state legislature after the Civil War, and T.B. Davis filled an unexpired term in the U.S. House of

separated Scherr from Patterson's Creek, with Burlington located roughly in the middle. The railroad did not connect any of these towns, but both were the product of population growth that these counties experienced as a result of the railroad. The Burlington congregation formed in 1893, with the Scherr body, called Greenland, forming in 1914. Elders from the Keyser church played a part in organizing both groups. No membership records for either congregation survive. See Robert Bell Woodworth, A History of the Presbytery of Winchester (Synod of Virginia): Its Rise and Growth, Ecclesiastical Relations, Institutions and Agencies, Churches and Ministers, 1719-1915 (Staunton, VA: The McClure Printing Company, 1947), 404-413; 444, 445. For a complete list of the churches established in the Presbytery of Winchester during this period and the dates of their erection, see pp. 444 and 445 of Woodworth's book.

\footnotetext{
47"Statistical Reports," Minutes of the General Assembly of the Presbyterian Church in the United States, 1880, 317; "Register of Communicants," Piedmont Presbyterian Church, n.d., 30-104; "Records of the Session," Piedmont Presbyterian Church, n.d., 6, 7.

${ }^{48}$ Ross, 41.
} 
Representatives in the early 1900s. ${ }^{49}$

Generally speaking, church leadership reflected the varied congregation. McCoole served as an elder before moving to the Keyser church. Throughout the 1880 s and 1890s, managers and craftsman served as elders and deacons, with no members of the industrial elite occupying those positions after the mid-1870s. By the early twentieth century, skilled industrial workers began holding leadership positions in the congregation. They first occupied the deaconate, and by the second decade of the century they served as both elders and deacons with equal frequency as men from the middle class. Throughout the Progressive Era, elders and deacons came from every rank of society except the highest and the lowest. While no members of the upper class held leadership positions in the church, no unskilled laborers did either. ${ }^{50}$ Working class persons apparently felt comfortable at Piedmont Presbyterian and had the opportunity to hold church offices.

During the Gilded Age and into the twentieth century, the church grew at a glacial pace. Denominational scholar Robert Woodworth noted that the period of the most substantial decrease, between the mid-1870s and mid-1880s, coincided with the rise of Keyser as an economic and political center for the county. ${ }^{51}$ Before the turn of the century, however, the congregation barely increased over the eighty members it had in 1880. As late as 1905, just eighty-six people belonged. However, the next fifteen years witnessed solid and consistent

\footnotetext{
49،"Records of the Session," Piedmont Presbyterian Church, n.d., 6; Darrell E. Holmes, ed. West Virginia Blue Book (Charleston, WV: Chapman Printing, 2001), 444, 445.

50"'Roll of Elders," Piedmont Presbyterian Church, n.d, n. p.; "Roll of Deacons," Piedmont Presbyterian Church, n.d., n .page; Ninth Census of the United States, 1870; Tenth Census of the United States, 1880; Twelfth Census of the United States, 1900; Thirteenth Census of the United States, 1910; Fourteenth Census of the United States, 1920. After the initial list of Trustees from 1855, no other record of trustees remains. It is probable, though not verifiable, that elders and deacons also served as trustees.

${ }^{51}$ Woodworth, 423.
} 
growth, with membership peaking at 220 in $1920 .^{52}$ Such growth may be suggestive of the church's evangelistic efforts. The population of Mineral County continued to grow between 1900 and 1910, but the population of Piedmont and the surrounding mining regions had leveled off, and in a few places had started to decline. ${ }^{53}$

While Presbyterians had been instrumental in initiating the Second Great Awakening in the early years of the nineteenth century, some quickly came to reject "new measures" for winning converts. Thus, by mid-century, especially in the South, revivalism was associated more with Baptists and Methodists. Generally speaking, Southern Presbyterians continued to frown upon what they perceived as human methods, while Northern Presbyterians, mostly of the New School, re-embraced the practice. In the twilight of the nineteenth century, revival fires again erupted, this time mostly in urban areas, during what religious historian William G. McLoughlin termed the "Third Great Awakening." 54

The liberal social gospel entered this phase of American religious development, while conservative evangelicalism and rising fundamentalism comprised the traditionalist wing. The latter segment employed revivals and mass meetings with great success in the first two decades of the twentieth century. Most of these were interdenominational, emphasizing shared allegiance to the "old time religion" over denominational particulars such as the mode of baptism or the form of church government.

\footnotetext{
52“"Statistical Reports," Minutes of the General Assembly of the Presbyterian Church in the United States, 1920, 303.

${ }^{53}$ Thirteenth Census of the United States: Population, Vol. 3, 1910, 1021.

${ }^{54}$ William G. McLoughlin, Revivals, Awakenings, and Reform (Chicago: University of Chicago Press, 1980), 141144. For more on the Presbyterian role in the Second Great Awakening and the development of revivalism, see Leigh Eric Schmidt, Holy Fairs: Scotland and the Making of American Revivalism (Grand Rapids: Eerdmans, 2001); Nathan O. Hatch, The Democratization of American Christianity (New Haven: Yale University Press, 1991); and Roger Finke and Rodney Stark, The Churching of America, 1776-2005: Winners and Losers in Our Religious Economy (New Brunswick, NJ: Rutgers University Press, 2005), among many others.
} 
Through the Progressive Era, Presbyterians in the mountains showed their willingness to participate in union (interdenominational) revival meetings. The pastor of the Piedmont church participated in one in 1914, although no record remains of how many communicants the church gained as a result of the meeting. ${ }^{55}$ Three years later, churches in nearby Keyser invited nationally renowned evangelist George Stephens to their town to hold meetings for a week. The Reverend Stephens did all the preaching during the week, with the pastor of the Keyser Presbyterian Church, The Reverend A.N. Perryman, featuring prominently in other revival activities. Held a in a large tent called the Tabernacle, these services resembled others in the D.L. Moody/Billy Sunday style. In addition to daily preaching services during the week and three on Sunday, the revival also included special prayer services and hymn singing. ${ }^{56}$

Like the Moody meetings of the 1870s and 1880s, the revival and related activities catered broadly to those involved in the industrial sector. Reverend Stephens held a special lunch for the business and professional men of the town, and a dinner for the businesswomen of the town. Women of all classes and all industrial occupations were specifically invited, whereas the invitation to the men did not mention wage earners or unskilled workers. ${ }^{57}$ Thousands of people gathered for the religious services, with twelve joining Keyser Presbyterian. Many of these newcomers were young people, and they came from all backgrounds and walks of life. ${ }^{58}$ This does not seem like very many people, especially considering the number of attendees at the services. However, other churches participated, and so likely gained members as well.

\footnotetext{
55"Record of the Session," Piedmont Presbyterian Church, 1914, 9. For more on the Piedmont church, see Woodworth, The Presbytery of Winchester, 422-427.

56،'The Stephens Party Now Working in Keyser,” Mineral Daily News, Feb. 12, 1917.

57،"People Are Thinking About Their Souls,” Mineral Daily News, Feb. 24, 1917.

58،Minutes of Session,” Keyser Presbyterian Church, 1917, 264.
} 
Furthermore, many of the attendees probably already belonged to a local church.

Despite the comparatively small addition from the revival, the twelve that joined the church not only represented a balanced cross-section of society, but they also reflected the existing social composition of the church. The Keyser church formed in 1892 from the merger of two churches - Mt. Hope and Calvary. Mt. Hope, in what was then called New Creek, dated to 1853 . It and the Piedmont church constituted a charge and shared a pastor. ${ }^{59}$ In 1887 , another Presbyterian church, Calvary, opened in Keyser. It formed from a rather messy split in the Mt. Hope congregation. ${ }^{60}$ The animosity between the old and the new churches was so great that Calvary affiliated with the Northern Presbyterians. However, wounds healed quickly, and the congregations re-merged in 1892, thus terminating any relationship with the PCUSA. The Piedmont-Keyser charge also dissolved, and each church had its own pastor. ${ }^{61}$

On the eve of industrialization, the leadership at Mt. Hope reflected the old agrarian order. The elders were farmers and lawyers, as were most of the deacons. Some of the members came from the ranks of the clerical class, but most were also farmers. While New Creek (later Keyser) lay along the $\mathrm{B} \& \mathrm{O}$ mainline, it, along with the rest of Mineral County, was still dominated by agricultural interests. That would soon change. By 1885 , increasing numbers of industrial laborers joined both churches. By the year of the merger, Calvary had an elder from

${ }^{59}$ A "charge" was a group of churches served by a single pastor.

${ }^{60}$ Charges of plagiarism and prevarication precipitated the schism. Believing the pastor to have acted inappropriately, two elders refused to attend services, and brought charges against the pastor before the presbytery. The remaining elders then brought counter-charges of character defamation against the dissenting elders. The presbytery reprimanded the pastor, but did not remove him. Not satisfied, the plaintiffs attempted to use the Session (board of elders) of the church to further discipline the pastor. The pastor and his allies called a meeting of the entire congregation during which two new elders were installed and the malcontents stripped of their offices and ousted. Another round of suits before the presbytery ensued. The juridical body ruled that the new elders were illegitimate and that the old ones must be re-instated. Conflict continued until 1887 when the original dissenting elders left with seventeen members to form Calvary Presbyterian Church.

${ }^{61}$ Woodworth, 415-422; 444, 445. 
among the merchant class and a deacon from the working class, albeit a skilled one. Over the next thirty years, the congregation and its leaders resembled those of their co-religionists in Piedmont. Members hailed from all classes, and leadership opportunities existed for men of all classes. Lawyers, farmers, railroad agents, shop foremen, and locomotive engineers alike served as elders and deacons. Like the Piedmont church, however, unskilled workers, for whatever reason, did not serve as elders or deacons. ${ }^{62}$

Unlike the Piedmont church, which experienced slow growth before 1900, the Keyser congregation increased quickly with industrialization. A membership of eighty-five in 1880 expanded to 130 just five years later. The rate of growth then slowed, but new congregants continued to join the church at a steady pace through the Progressive Era. In 1900, 168 people belonged to the church. By 1920, the rolls contained 261 names. ${ }^{63}$ The Session expected these members to honor the covenant each of them had with God and with the church. This included attending services regularly and partaking in the Lord's Supper. The Session sent letters to those too frequently absent from worship, reminding them of the commitment required of them as church members. Those persisting in error risked being disciplined. The church also specifically maintained a clear and uncompromising position against dancing and other forms of worldly amusement. The Session admonished the young people in particular to not get "carried away with the world's delusions."

The Piedmont and the Keyser congregations represented a continued emphasis on classic Presbyterian polity and doctrine amidst changing secular surroundings. Even as the composition

\footnotetext{
62،"Minutes of Session,” Keyser Presbyterian Church, 1876-1921, 26-391.

63“'Statistical Reports," Minutes of the General Assembly of the Presbyterian Church in the United States, 1880, 317; "Statistical Reports," 1885, 527; "Statistical Reports," 1900, 152; "Statistical Reports," 1920, 303.

64“Minutes of Session,” Keyser Presbyterian Church,” 1885, 59, 60; “Minutes of Session,” $1877,31$.
} 
of the church and its leadership increasingly reflected the new social and economic order, Presbyterianism in Mineral County, which for the most part pre-dated industrialization, remained wedded to the traditionalism of the PCUS. Records for the Presbyterian churches in Randolph County contain similar concern for keeping the covenant and ensuring the proper ecclesiastical and spiritual order. Furthermore, the Elkins and Beverly churches, the two largest and oldest in the county, also used revivals as a means to strengthen and enlarge the congregations. In fact, records indicate the Beverly church practiced revivalism much earlier than others in the mountains, beginning in $1879 .{ }^{65}$ In contrast to the Mineral County churches, however, industrialization produced a somewhat different congregational composition in these two Randolph County bodies. While both came to have relatively diverse congregations, egalitarianism was largely absent. Church leadership continued to reflect the secular power structure through the Progressive Era.

Ministers working with the Redstone Presbytery (in the Synod of Pittsburgh) first introduced their faith to the Tygart Valley before the American Revolution. However, it would be several decades before the denominational hierarchy established formal churches in the region, despite frequent requests to do so by local faithful. In 1823, the Synod of Pittsburgh detached the Tygart's Valley churches to the Synod of Virginia and the Presbytery of Lexington, but assigned a single pastor to the entire valley. Finally, in 1869, the Presbytery of Lexington organized three separate churches, each with its own pastor. The Leading Creek Church, located in Leadsville, served the northern end of the county while the Beverly Presbyterian Church accommodated the central portion. The faithful in the southern part of the county attended the Tygart's Valley Church, which had one congregation in Huttonsville and another in Mingo

\footnotetext{
65“Minutes of Session, Book I," Beverly Presbyterian Church, 1879-1883, 39, 54, 71; “"Minutes of Session, Book II," 1893, 44; Ross, 37, 38.
} 
Flats. $^{66}$

By 1880, the Beverly and Huttonsville congregations were the largest in the county, with 110 and 80 members respectively. Leading Creek had just 40 parishioners. Farmers dominated all three churches. On the eve of industrialization, some of the wealthiest farmers and lawyers in the county held the offices of elder and deacon in Beverly. Elder David Goff, a lawyer, served in the state Senate in mid-1870s. In 1881, one of the deacons, C.J.P. Cresap, also an attorney, represented the county in the House of Delegates. ${ }^{67}$

The WVC\&P reached Beverly in the 1890s and Huttonsville before the turn of the century. Timbering was not a major industry in the area, but, in addition to the railroad, some coal mines opened between those two towns. Despite this modest industrial growth, the congregation of the Beverly church continued to hail almost exclusively from the agricultural sector. A few railroad workers joined in the early 1900s, but for the most part the only non-farm workers who joined were teachers and lawyers. Through the turn of the century, the wealthiest farmers and most prominent lawyers continued to dominate the Session. One of those attorneys, T.R.P. Brown, served a term in the House of Delegates in the final years of the nineteenth century. Farmers and lawyers also continued to control the deaconate, with J.B. Ward, Davis's lawyer in the region, serving the church in that capacity. However, by 1900 a merchant and a silversmith had been elevated to the position as well. ${ }^{68}$

Throughout the Progressive Era, the membership of the church remained much as it

\footnotetext{
${ }^{66}$ Ross, $2-10$.

67"Statistical Reports," Minutes of the General Assembly of the Presbyterian Church in the United States, 1880, 312; "Minutes of Session, Book I," Beverly Presbyterian Church, 1871-1881, 37-126; Holmes, 422, 450; Ninth Census of the United States, 1870; Tenth Census of the United States, 1880.

68“"Register of Communicants, Book II," Beverly Presbyterian Church, 1891-1900, 30-115; Holmes, 450; Twelfth Census of the United States, 1900.
} 
always had. Industrial workers and merchants continued to join, but farmers, both big and small, still comprised most of the congregation. With the removal of the county seat to Elkins, however, many of the lawyers moved to Elkins and united with that fellowship. ${ }^{69}$ Church leadership eventually began to reflect the shift in membership. By 1921, a farm worker became a deacon. Based on available records, this seems to be the first time a member of the working class occupied a position of leadership within the congregation. Nevertheless, wealthy farmers and merchants continued to control the Session. ${ }^{70}$

Over the course of the Gilded Age and Progressive Era, the Beverly church did not demonstrate the mass appeal of Presbyterianism as its co-religionists in Mineral County did. However, the social and economic conditions of Beverly and the surrounding environs did not reflect the changes of industrialization to the extent that towns in Mineral County did. The industrial working class was not as numerous in the middle section of Randolph County. What records remain from Methodist churches in the area around Beverly suggest that denomination exerted a strong appeal on landless farmers and farm workers (See Chapter 4). Those factors helped preserve secular elite control in the Presbyterian church.

${ }^{69 ، " R e g i s t e r ~ o f ~ C o m m u n i c a n t s, " ~ D a v i s ~ M e m o r i a l ~ P r e s b y t e r i a n ~ C h u r c h, ~} 10$.

70،"Register of Communicants, Book II," Beverly Presbyterian Church, 1906-1912, 159-269; "Register of Communicants, Book III," 1920-1921, 17-56; Thirteenth Census of the United States, 1910; Fourteenth Census of the United States, 1920. The Huntersville Church in Pocahontas County underwent similar changes at the time. Located in what was the county seat, the church consisted of farmers and lawyers. Over the last three decades of the nineteenth century, three members represented the county in the House of Delegates. At the same time, the congregation barely had more than thirty members, and after the organization of the Marlin's Bottom Church (later Marlinton) in 1881, parishioners were even fewer. However, the church retained some of its elite members until 1900, when the Greenbrier Railway came through Marlinton, cutting offer Huntersville. This occurred seven years after the county seat moved to Marlinton. The Marlinton Presbyterian Church fared better. Founded in 1881 with a twelve member congregation, the church did not grow in its first decade. By 1900, however, it had fifty-two members. That number more than doubled by 1910 , when membership stood at 127 . Growth slowed over the final decade of the Progressive Era. The church counted 138 members in 1920. No other membership records remain. See Holmes, 449; Jane Price Sharp and William Price McNeel, eds. History of Pocahontas County, West Virginia, 1981: Birthplace of Rivers (Marlinton, WV: Pocahontas County Historical Society, 1981), 133; "Minutes of Session," Huntersville Presbyterian Church, 1877-1920; "Marlin's Bottom Church Organized," Minutes of the Greenbrier Presbytery; "Statistical Reports," Minutes of the General Assembly of the Presbyterian Church in the United States, 1890, 170, 171; 1900, 763; 1910, 249; 1920, 271. 
During the same period, secular elites dominated the Leading Creek Church. Located in what became Elkins, in 1895 the name changed to Davis Memorial Presbyterian Church in honor of H.G. Davis's mother, a year after he donated money to build a new stone house of worship. ${ }^{71}$ Despite the population increase Elkins experienced almost immediately due to the railroad, the Presbyterian church in the town remained of modest size. In fact, as late as 1905 it was still smaller than its Beverly counterpart, which peaked that year at 279 members. By 1910 , however, the situation was reversed and Davis Memorial was clearly the largest Presbyterian church in the county with nearly 400 members. Beverly, by contrast, had just 185 and would continue to shrink over the next decade. By 1920, Davis Memorial claimed nearly 600 members, making it the second largest Protestant church in the county and the largest church in the Tygart's Valley Presbytery. $^{72}$

Clearly, something about Presbyterianism attracted the people of Elkins, both elite and non-elite. After all, Presbyterians outnumbered Baptists throughout the Alleghenies. Membership records from the mid-1890s through 1920 reveal a socially diverse congregation. In this sense, Davis Memorial probably had the most diverse congregation in the mountains.

Farmers continued to attend, as did professionals such as doctors and lawyers, but the industrial sector of the economy was also well-represented. H.G. Davis and Stephen B. Elkins and their families joined shortly after moving to town, as did many of their agents and managers. Between 1910 and 1920, three state legislators worshipped there. Clerks and laborers, both skilled and unskilled, also joined the church in notable numbers. ${ }^{73}$

\footnotetext{
${ }^{71}$ Henry Gassaway Davis, “Journal,” Sept, 29, 1895.

72،"Statistical Reports," Minutes of the General Assembly of the Presbyterian Church in the United States (Richmond: VA, Presbyterian Committee on Publication, 1920), 278.

73،"Register of Communicants," Davis Memorial Presbyterian Church, n.p.; Twelfth Census of the United States, 1900; Thirteenth Census of the United States, 1910; Fourteenth Census of the United States, 1920; Holmes, 450.
} 
There was little chance a working-class individual could wield any power or influence in the church, save voting on its leadership. Like the Beverly church, farmers originally held power in the Elkins church. The old farmers continued to control the Session through the end of the century, but by the mid-1890s, members of an emerging merchant class already held positions on the board of deacons. One deacon was a railroad carpenter, but by 1910 he had purchased his own farm and left the industrial sector. Between 1900 and 1920, most of the deaconate consisted of lawyers and merchants. The most prominent among them was Howard Sutherland, who was elected to the West Virginia Senate and then surrendered his spot on the board to serve in the United States House of Representatives ${ }^{74}$

The elders, or members of Session, were an even more socially exclusive group, with no one from the working classes among them. Most were doctors and lawyers. The Session also included such prominent citizens as C. Wood Dailey (a lawyer and one of Davis' lieutenants, and a former Delegate from Mineral County) and James A. Allen, the President of Davis and Elkins College. The least among them in the secular world was a bank cashier. As was the case with other Presbyterian churches at the time, elders and deacons also acted as Trustees, rotating their terms in office. Davis and Elkins were the exception to this rule. Each became a Trustee upon joining and held the position for life, but neither acted as a deacon or elder. ${ }^{75}$

The social composition of the Elkins churches fills in another part of the spectrum of Presbyterianism in the mountains. Among churches in the mountains that pre-dated industrialization, that congregation changed the most amidst a shifting secular order. The social

\footnotetext{
74،"Register of Deacons," Davis Memorial Presbyterian Church, 5; Twelfth Census of the United States, 1900; Thirteenth Census of the United States, 1910; Holmes, 422.

75“Register of Deacons," Davis Memorial Presbyterian Church; Twelfth Census of the United States, 1900; Thirteenth Census of the United States, 1910; Fourteenth Census of the United States, 1920; Ross, 127. Elders and deacons also rotated terms as Sunday School Superintendent. See Ross, 132.
} 
diversity of the Keyser, Piedmont, and Elkins congregations indicates an element of popular religiosity in West Virginia Presbyterianism. At the same time, the fact that the Beverly and Elkins bodies remained in the control of secular elites into the 1920s, albeit elites from different economic orders, highlights the attraction of that denomination to those in power in the secular sphere. In both cases, secular elites exhibited extreme reluctance to surrender power in the sacred sphere. The new Presbyterian churches, those established as a result of industrialization, complete this picture of a denomination holding secular/sacred hierarchy and popular religion in tension.

\section{Centralization During the Progressive Era}

By 1890 , the presbyteries had established four new churches in the mountain counties of West Virginia. Three of them were along the WVC\&P mainline, with the fourth established in a town along its proposed route extension. The county seats of Mineral, Randolph, and Pocahontas County each had a Presbyterian church. ${ }^{76}$ The decentralized approach appeared to be working. However, conditions continued to change rapidly. As the railroad continued to open up new areas for development, more towns formed and more people moved in. Perhaps growth in the secular sphere would exceed the church's ability to minister to the growing population.

As early as 1887, before the West Virginia Central and Pittsburg reached Elkins, the synod entertained the possibility of switching to the synodical home missions pioneered by Edward O. Guerrant in Kentucky. After a lengthy discussion, the Committee on Home Missions decided against changing its methods of evangelism. In good Presbyterian spirit, it asserted that "we need only to persevere and to apply them [existing plans and methods] more vigorously and

\footnotetext{
76،"Statistical Reports," Minutes of the General Assembly of the Presbyterian Church in the United States, 1890, 169-173, 176-179; Robert Bell Woodworth, A History of the Presbytery of Winchester (Synod of Virginia): Its Rise and Growth, Ecclesiastical Relations, Institutions and Agencies, Churches and Minister, 1719-1945 (Staunton, VA: The McClure Printing Company, 1947), 442, 443.
} 
with a zeal more fervent."77

Despite this vote of confidence, the issue did not die. In 1890, the subject was broached again. The Special Committee on Evangelization acknowledged that greater centralization of missions was needed and argued that the synod must take over this responsibility because the presbyteries most desperate for missionaries were those least able to provide them. The synod knew this task traditionally belonged to the presbyteries, but, having consulted with the Synod of Kentucky, offered its own plan for synodical evangelization. The synod would form a regular Synodical Committee on Evangelization to oversee all home missions work within its bounds. To supplement its budget, it would designate a particular Sunday in November to collect money especially for missions. The new body would also appoint and support evangelists. However, the authority of the synodical evangelism committee would not supersede that of the various presbyterial home missions committees. The evangelists would serve at the request of the presbyteries and would go where directed by those bodies. The synod would directly control evangelistic work only in completely spiritually destitute areas outside the bounds of a presbytery. $^{78}$

The synod adopted the plan, becoming the third synod in the PCUS to adopt some form of synodical missions. ${ }^{79}$ A spirit of cooperation between the synod and the presbyteries quickly

\footnotetext{
77،The Report on the Committee on Home Missions," Minutes of the Synod of Virginia, 1887, 413. At this point, the Committee on Home Missions primarily served as a liaison between the General Assembly and the presbyteries. It raised and distributed some funds and kept records of home missions work within its bounds. Overall however, it played a very minor role in actual missions operations.

78،"Synodical Evangelization,” Minutes of the Synod of Virginia, 1890, 99-101.

${ }^{79}$ Thompson, Presbyterians in the South, Vol. 3, 31. After Kentucky, in 1889 North Carolina became the second synod to adopt synodical missions. In the early 1890s, synodical missions became increasingly popular and the existing home mission plans of the General Assembly became increasingly unworkable. Interestingly, as home mission work became more centralized in the synods, it became more decentralized at the national level. In 1893, the General Assembly replaced the Preferred and Optional Plans. Under the new system, synods and presbyteries were urged to fund and execute evangelistic activity completely on their own. A separate collection would be taken to fund the Assembly's Executive Committee on Home Missions, whose work would now be devoted exclusively to
} 
developed. The added support did boost missionary activity. Perhaps not surprisingly, most presbyteries took advantage of the additional funds available to them. Rather than call upon the synodical evangelists, many presbyteries used the money from the synod to pay their own missionaries. It was not long until synodical evangelists were active throughout the Synod of Virginia, in both Virginia and West Virginia. ${ }^{80}$ The individual presbyteries clung to their responsibility for home missions within their territories, forcefully asserting oversight of all missionaries within their bounds. They maintained strong home missions committees, funded them as best they could, and remained the first source of financial aid to destitute churches. The presbytery also filled vacant pulpits. ${ }^{81}$

Debate continued within the synod, however. In 1895, just five years after establishing a centralized mission plan, many called for even greater concentration of home mission prerogatives in the synod. The Synodical Committee on Home Missions advocated assuming complete control of all missionary activity in its territory. After a careful review of the work of presbyteries, however, the committee reconsidered, believing it wise to maintain the status quo. The presbyteries had re-doubled their efforts at evangelizing their territories, and many on the committee admitted that restructuring for missions could cause more problems than it would solve. Thus, while some modification did take place, the Synod of Virginia ended the nineteenth century committed to the application of essential Presbyterian principles. By 1900, amidst considerable social and economic upheaval in the mountains, the primarily presbytery-based home missions scheme continued to yield results. In the final decade of the nineteenth century,

\footnotetext{
"frontier" areas. Weaker presbyteries in older synods would be helped by other presbyteries in the same area, not by the General Assembly.

80“"Synodical Evangelization,” Minutes of the Synod of Virginia, 1894, 362.

81،"Report of the Home Mission Committee," Minutes of the Greenbrier Presbytery, 1895, 124, 125.
} 
the Greenbrier, Winchester, and Lexington presbyteries organized eight new churches within the five mountain counties studied here. Six of those stood in towns along rail lines cutting through the region. ${ }^{82}$

This success highlights the importance of the railroad as much, if not more so, than the effectiveness of the presbytery-based missions system. Commissions organized these churches in towns that barely existed, or in some cases did not exist, just a few years prior to the coming of the Iron Horse. Churches in such places as Elk Garden, Gormania, and Bayard, all in Mineral and Grant counties, grew in the wake of industrial development in these mining towns. ${ }^{83}$ Two other churches, those in Parsons and Davis, both important towns in Tucker County along the WVC\&P, also demonstrated the complex relationship between Presbyterianism and secular authority. Neither church was very large during this time, but both owed their existence to the railroad and the new industrial order that accompanied it. Without the railroad, neither Davis nor Parsons would have existed, and, in all probability, neither would those churches.

In 1886, two years after the railroad rolled into the town of Davis, the Winchester Presbytery organized a church there ${ }^{84}$ From the beginning, a close connection existed between the church and industrialization. The church's early history also demonstrates how Presbyterian polity worked with technological advances to advance the gospel. William Wilson, a former elder at a Presbyterian Church in western Maryland, moved to Davis to become the superintendent of a new tannery, and soon started a Presbyterian Sunday School. For several

\footnotetext{
82“"Statistical Reports," Minutes of the General Assembly of the Presbyterian Church of the United States, 1900, 144147, 151-153. Woodworth, 444, 445. Of course, the total number of churches added within the bounds of these three presbyteries was far greater than eight. Thus, the success of these presbyteries demonstrates the continued effectiveness of the traditional approach to evangelizing new territory.

${ }^{83}$ Woodworth, 445.

${ }^{84}$ Minutes of the Winchester Presbytery, 1886, 101; Tenth Census of the United States, 1880; Twelfth Census of the United States, 1900; Thirteenth Census of the United States, 1910; Fourteenth Census of the United States, 1920.
} 
months, the minister at the Holly Meadows church, the only Presbyterian Church in Tucker County, became the first regular preacher for the small band of believers in the new town. By the end of 1886, the Presbytery of Winchester, recognizing the need for a church along the railroad, sent a commission of ministers from Mineral and Hampshire Counties to organize a church, install a pastor, and unite it with the presbytery. ${ }^{85}$

The leadership and the membership of the new church also reflected the new industrial order in the region. Its fourteen original members came from all social classes, ranging from bank president to coal miner. During the Gilded Age and Progressive Era, very few farmers joined the congregation. Most of its parishioners worked in a variety of positions in the mining, timbering, or railroad industries. White collar professionals and clerks also worshipped there. ${ }^{86}$ From the original fourteen members, the church grew quickly, with fifty-eight congregants in 1890. But then growth slowed, even as the town grew. At the turn of the century, membership declined to forty-six. The church did not have more than 100 members until 1915, when it reached 110 ; it peaked at 146 in $1920 .^{87}$

The membership was about as diverse as the area would allow. Davis was a new settlement, founded by H.G. Davis for coal mining and coke and timber production; it was situated in the Alleghenies at over 3000 feet. Thus, few farmers lived in the town. Most of the residents worked in the extractive or manufacturing sectors, with a majority of the rest working in the retail and service sectors. To some extent, church leadership reflected a good cross-section of the congregation. The original Session, which consisted of three elders, was comprised of a

\footnotetext{
${ }^{85}$ Robert Woodworth, “Davis Presbyterian Church, Fiftieth Anniversary Address,” July 18, 1937, 3, 4.

86،"Register of Communicants," Davis Presbyterian Church, n.d, n. p.; Woodworth, 4; Twelfth Census of the United States, 1900.

87،"Statistical Reports," Minutes of the General Assembly of the Presbyterian Church of the United States, 1890, 180; 1900, 152; 1915, 273; 1920, 302.
} 
tannery superintendent, the chief engineer of the railroad, and a coal miner. Two of these men had served as elders in other churches, while the third had been a deacon. Over the next thirtyfive years, the elders hailed entirely from the merchant class. Most of them owned their own stores, but a few worked as clerks. However, members of the industrial elite and their lieutenants, as well as industrial laborers, did not hold that position. ${ }^{88}$

The composition of the diaconate during this period was slightly more diverse. Like the elders, most of the deacons worked in the service or retail sector, but a few did come from among the highest and lowest ranks of society. Of the four original deacons, one was a stone mason, but two others were company men, one an auditor for an unspecified coal company and the other a supervisor for the West Virginia Coal and Coke Company, one of Davis' operations. ${ }^{89}$ This basic pattern continued during the first two decades of the twentieth century. Over the course of his ministry, one particular deacon held several prominent positions in the new industrial economy. In addition to owning his own businesses, he also served as the President of the National Bank of Davis and general manager for the Buxton and Landstreet Company, the Davis Coal and Coke Company general store. Two other deacons practiced medicine, while one worked as a salesman and another mined coal. ${ }^{90}$

\footnotetext{
${ }^{88}$ Robert Woodworth, 4, 11; Tenth Census of the United States, 1880; Twelfth Census of the United States, 1900; Thirteenth Census of the United States, 1910; Fourteenth Census of the United States, 1920.

${ }^{89}$ Minutes of the Presbytery of Winchester, 1887, 128.

${ }^{90}$ Woodworth, "Davis Presbyterian Church...," 12; Tenth Census of the United States, 1880; Twelfth Census of the United States, 1900; Thirteenth Census of the United States, 1910; Fourteenth Census of the United States, 1920. In 1899, a decade after lay believers formed a Presbyterian Sunday School there, the Presbytery of Winchester established a congregation in Thomas, the sister city of Davis. There were eight charter members. Almost no records survive, but those that do hint that the Thomas church and the Davis church had similar social compositions, both in the congregations in general and the leadership in particular. The first two elders were a coal miner from Scotland and a native-born railroad freight agent. The rest of the congregation included the wives of the two elders, a merchant's wife, and a clerk's wife. The Thomas church remained comparatively small, reaching just ninety members in 1925. See Cleta M. Long, History of Tucker County, West Virginia (Parsons, WV: McClain Printing Company, 1996), 158.
} 
The Presbyterian Church of Parsons also displayed the close connection between that denomination and industrialization. In fact, it and the Elkins church probably highlighted that connection more than any other churches in the mountains. The Davis church showed how Presbyterians used the railroad to their advantage, and further demonstrates how the denomination continued to embody at least some elements of popular religion. The Parsons church reflected similar connections. More importantly, the congregation, like that of Elkins, strongly suggested that the Southern Presbyterian Church was indeed the church of industrialists in the Alleghenies.

In 1875, an evangelist working with the Presbytery of Lexington gathered a small group of believers at Holly Meadows in Tucker County, located about three miles north of the head of the Cheat River (present-day Parsons). Three years later, a presbyterial commission organized a church of eight members, all farmers, which became the first Presbyterian Church in Tucker County. ${ }^{91}$

Many of the leading citizens in the area, led by the Parsons family, allied with H.G. Davis to bring the railroad south to the head of Cheat. In 1898, a decade after the formation of the new town of Parsons, the Parsons family and several others, all of whom belonged to the Holly Meadows congregation, asked the Presbytery of Winchester to establish a new church in Parsons. ${ }^{92}$ Twenty-two members formed the new church. In addition to some of the wealthiest farmers in the area, the congregation also included a few merchants and industrial laborers. The Parsons and other members of the Parson Presbyterian Church all featured prominently in the

\footnotetext{
${ }^{91}$ Woodworth, 1.

${ }^{92}$ Mariwyn M. Smith, comp., "Records and Minutes of the Presbyterian Church,” 1992, 21.
} 
effort to transfer the county seat from St. George to Parsons. ${ }^{93}$

There was more to this industrialist connection. Records are almost non-existent, but membership lists from the St. George Methodist Episcopal Church indicate that at least one major wing of the Parsons family belonged to that church in the 1870s and 1880s. Sansome E. Parsons, the half-uncle of Ward, who led the group that allied with Davis and Elkins, served in several capacities in that church and in the St. George Circuit (MEC) during that time. ${ }^{94}$ Sometime after 1885 he joined the Presbyterian Church in Holly Meadows and in 1898 he became one of the first elders of the Parsons Presbyterian Church. ${ }^{95}$

Many factors can contribute to changing denominations. However, the fact that S.E. Parsons, an active Methodist, so quickly became a leading Presbyterian, coupled with the fact that this conversion occurred during industrialization, suggests a connection between Presbyterianism and the changing secular order. The Parsons family, most of whom were Presbyterians, allied with H.G. Davis, who was also a Presbyterian. To be sure, the evidence does not prove this alliance was caused simply by religious commonality. Rather, this combination of links between secular authority and Presbyterianism shows that many of the industrial elite, whether local or absentee, found Presbyterianism agreeable and that factors other than personal religious conviction may have been involved in denominational re-affiliation.

\footnotetext{
${ }^{93}$ Mariwyn M. Smith, comp., "Chronological Roll,” 1992, 1; Tenth Census of the United States, 1880; Twelfth Census of the United States, 1900; Ronald L. Lewis, Transforming the Appalachian Countryside: Railroads, Deforestation, and Social Change in West Virginia, 1880-1920 (Chapel Hill: The University of North Carolina Press, 1998), 222, 223.

94،"Quarterly Meeting Minutes of the St. George Circuit, MEC,” 1875-1885, n.p. Ward Parsons remained at Holly Meadows, also called Bethel, after the formation of the Parsons Church. His religious affiliation prior to the organization of that congregation remains unknown. See Homer Floyd Fansler, History of Tucker County, West Virginia (Parsons, WV: McClain Printing Company, 1962), 629.

${ }^{95}$ Mariwyn M. Smith, comp., "Parsons Presbyterian Church Elders,” 1992, n. p.
} 
Stephen B. Elkins had been a Baptist before his partnership with H.G. Davis. ${ }^{96}$

Through the 1920s, the town of Parsons, while it did become the county seat, never achieved the regional prominence of the town of Elkins. In fact, the town of Davis had a larger population and the Davis church had a larger congregation during the period. Like the Davis church, Parsons experienced rapid growth within the first few years. By 1905, membership had doubled to fifty-three. Through 1920, however, its membership never exceeded 100, peaking at ninety-four in 1915. Like the Mineral churches and Davis Memorial, this congregation had a diverse membership, boasting roughly equal numbers of farmers, industrial workers, merchants, professionals, and managers over the course of the Progressive Era. ${ }^{97}$

Despite comparatively low membership, the church drew some of its leaders from the elite ranks of society. In addition to S.E. Parsons, other members of the Parsons family, all of whom were farmers, served as elders and deacons until 1910. Lemuel Parsons, Ward's son, held the positions of deacon and treasurer. Solomon Kalar, for a time the town mayor, was a trustee. Unlike Elkins, in which the new elite largely prevented even the middle class from exercising authority in the church, leadership in the Parsons church was open to all social groups almost from its beginning. The other founding elder was a merchant. By 1903, a doctor and a currier (a skilled tannery worker) joined the Session. Over the next decade, a tannery night watchman and pulp mill laborer also became elders. ${ }^{98}$

These two newer churches shared many characteristics with older churches in the mountains. The Parsons group demonstrated the close link between secular and sacred. Parsons, ${ }^{96}$ H.G..D., “Journal,” Nov. 7, 1895.

97"Statistical Reports," Minutes of the General Assembly of the Presbyterian Church in the United States, 1905, 202; 1915, 276; Smith, "Chronological Roll," 1-7.

${ }^{98}$ Smith, "Parsons Presbyterian Church Elders," n.p. Aside from Lemuel Parsons, no deacons names are mentioned; Lewis, 222. 
along with Beverly and Elkins, showed that secular elites, whether agricultural or industrial, expressed an affinity for Presbyterianism. Both Parsons and Davis had diverse congregations and men from all social classes had access to positions of power, even if fewer elders and deacons came from the industrial working classes. By attracting members of all social classes, both continued to prove that Presbyterianism, even when it came in on the rail, still exhibited facets of popular religion.

All three presbyteries with territory in the Alleghenies proved ready, willing, and able to use the new form of transportation to their advantage. In 1898 and 1899, two addition churches sprang up in Hendricks and Thomas, two new mining and timber towns in Tucker County. In 1904, the Presbytery of Greenbrier organized a church at the mill town of Cass in Pocahontas County in response to a request from the West Virginia Pulp and Paper Company, with support of the owner of the town and the lumber operation. The next year, the Presbytery of Lexington established a church in Glady, a timbering community in Randolph County. No detailed records exist for these congregations, but none of the churches grew very large during the first two decades of the twentieth century. ${ }^{99}$ Nevertheless, they reflected the popular religiosity of the denomination and helped make the Southern Presbyterian Church the second largest denomination in the mountains. Only Methodists achieved greater success in the region, and at times the Presbyterians arrived in various locations first.

The rapid expansion of Presbyterianism in the mountains mirrored a trend across the Mountain State. In 1895, for example, in response to expansion, the Synod erected a new

\footnotetext{
99"'Statistical Reports," General Assembly of the Presbyterian Church in the United States, 1910, 250; 264; 1920, 304, 306; Pocahontas Times (Marlinton, WV), January 13, 1901. With 75 members in 1920, Cass had one of the larger congregations in these industrial towns; Woodworth, 445; Roy B. Clarkson, On Beyond: Leatherbark, The Cass Saga (Parsons, WV: McClain Printing Company, 1990), 180; Jane Price Sharp and William Price McNeel, eds., History of Pocahontas County, West Virginia, 1981: Birthplace of Rivers (Marlinton, WV: Pocahontas County Historical Society, 1981), 126; Steve Bodkins, Bemis and Glady, West Virginia: A History of Two Mountain Towns (Parsons, WV: McClain, 2006), 47-50.
} 
presbytery - the Presbytery of Kanawha. The Greenbrier Presbytery was split almost in half, with its western portion forming the new body. The Presbytery of Kanawha extended from the central and southern counties of West Virginia west to the Ohio River. ${ }^{100}$

The Synod of Virginia recognized that this type of development resulted from railroad expansion and that this was only the beginning. As more industry took root, more people would move into the area. Few of these newcomers had experience with Presbyterianism; many were Roman Catholic. Like many Protestants during this period, Presbyterians viewed Catholicism with suspicion. Presbyterians in Virginia and West Virginia were no different, seeing the increase in Catholic immigration with great alarm. They even petitioned the General Assembly to form a committee to work with other Protestant bodies to monitor the Church of Rome, which the synod deemed "a menace or blight to civil and religious liberty of every kind wherever it has obtained a foothold." 101 Industrialization posed a number of new challenges, and the church had to be ready.

At the dawn of the twentieth century, West Virginia stood as the most promising missionary field within the bounds of the Synod of Virginia. Such great potential came with a price. The field was so large and filling so quickly with people that the church might not be able to evangelize it effectively. The synod took action to prevent being overwhelmed. First, it formed a Committee on Division of the Synod to investigate the possibility of creating a new synod, which would incorporate most of West Virginia, excepting a few southern counties and the eastern panhandle. In 1902, the committee concluded in favor of the new synod, believing

\footnotetext{
${ }^{100}$ Joe B. Overmeyer, History of the Presbytery of Kanawha, 1895-1956 (Charleston, WV: Jarrett Printing Company, 1957), iii-v. Denominational records always use the word "erect" when discussing the creation of a new synod, presbytery, or church.

101،"The Report of the Special Committee on the Painter Resolution,” Minutes of the Synod of Virginia, 1913, 289.
} 
the large territory which made up the Synod of Virginia could best be served by two synods. ${ }^{102}$

The next year, the Synod rejected the idea. However, it did finally move forward with plans to increase centralization of missions. A Special Committee on the Evangelistic and Home Mission Work of the Synod of Virginia developed a comprehensive plan of reorganization which merged the committees on evangelization and home missions into a single central advisory committee. This committee would appoint and pay a superintendent, whose sole responsibility would be coordinating all missions work in the territory. The rest of the committee would consist of the chairmen of the presbyterial home missions committees, three additional ruling elders, and two ministers. ${ }^{103}$

The synod adopted this strategy, which strongly resembled the arrangement adopted by the Synod of Kentucky nearly twenty-five years earlier. ${ }^{104}$ The Synod of Virginia now assumed considerable authority over missions. Of course, the presbyteries still had their own missionary organizations and schemes. Furthermore, once in a presbytery, the synodical evangelists would still be answerable to the presbyterial authorities. The fact that presbyterial mission leaders composed most of the synodical committee meant that the decision-making remained representative. The synod did recognize the need for much greater coordination and cooperation in this matter. If it hoped to continue to build additional churches, expand existing ones, and make converts, such new measures seemed necessary.

Over the first decade of the twentieth century, several smaller rail lines opened up the vast back country of the mountain counties, connecting it with the larger towns along the WVC\&P

\footnotetext{
102،CCommittee on Division of the Synod,” Minutes of the Synod of Virginia, 1902, 362-365.

103،"The Evangelistic Plan,” Minutes of the Synod of Virginia, 1903, 412.

104،'Synodical Evangelists and the Presbyteries," Minutes of the Synod of Kentucky, 1882, 81.
} 
mainline. The Synod stood in a good position to take advantage of this transportation revolution, and by 1910 its new plan seemed to be working. No new churches were added in Mineral County. Tucker and Grant added one each, Pocahontas two, and Randolph three. ${ }^{105}$ A New Presbytery and a New Synod

This data on Presbyterian missions in the mountains during the first decade of the twentieth century can be somewhat misleading. To be sure, several new churches sprang up throughout the Alleghenies, especially in Randolph and Tucker counties. However, once established, these churches grew slowly. Such mixed results prompted the Lexington Presbytery to overture the Synod of Virginia for the creation of a new synod, which would include the parts of the Lexington, Greenbrier, and Winchester Presbyteries west of the Alleghenies, in addition to the Kanawha Presbytery. ${ }^{106}$ The other presbyteries initially exhibited less enthusiasm for the plan, but that would soon change. Even the one presbytery that did support it questioned whether a new synod would be financially viable.

In the meantime, a new scheme emerged. The Lexington Presbytery explored creating a new presbytery out of its western counties, which comprised the majority of its territory. Despite the railroad, travel in the presbytery remained difficult. For all the rail lines that crisscrossed the territory in both Virginia and West Virginia, no east-west line crossed the mountains. The quickest route for commissioners to meetings of the presbytery was to use the C\&O's Durbin Route and H.G. Davis' Coal and Iron Railway, which required them to circle nearly two hundred miles (round trip) outside the presbytery. The increasing number of churches in West Virginia meant more and more people had to make the trip East and increased the frequency of meetings

\footnotetext{
105“Statistical Reports," Minutes of the General Assembly of the Presbyterian Church in the United States, 1910 , $550,551,763-766$.

106، Overture to the Synod of Virginia,” Minutes of the Lexington Presbytery, 1910, 350, 351.
} 
in West Virginia. These additional churches also strained the presbytery's financial and ministerial resources. The presbytery believed this transportation problem helped contribute to the slow growth of congregations in the west. ${ }^{107}$

Perhaps ironically, low membership numbers were a cause as well as an effect. Of twenty-seven "church organizations," only five were self-supporting, all of which lay along the West Virginia Central and Pittsburg mainline: three in Randolph County and two in Tucker County. In fact, the Winchester and Lexington Presbyteries both claimed Tucker County. In 1911, the Winchester body polled the congregations in that county and found that those in the northeastern part of the county - Davis and Thomas - preferred to stay with it, while those in the central and southwestern sections - Hambleton, Parsons, and Hendricks - wanted to join the Lexington Presbytery. Those three congregations were then ceded to the presbytery of their choice. ${ }^{108}$ Thus, one of the "church organizations" claimed by the Lexington Presbytery, the Davis-Thomas church, was not actually within its bounds.

Whatever the ecclesiastical organization, the western portion of the Lexington Presbytery would struggle to support if it became it a presbytery. Nevertheless, the Lexington body requested that the Synod create a new presbytery, the Presbytery of Tygart's Valley. Of the twenty-seven congregations in the new body, seventeen lay in Randolph and Tucker counties. Although the mother organization lost over half its land mass, it lost just over ten percent of its

\footnotetext{
107“"Report Concerning the Division of Lexington Presbytery," Minutes of the Lexington Presbytery, 1911, 421. The presbytery also considered dividing up its West Virginia counties between the Kanawha and Winchester presbyteries. However, the Lexington body concluded their sister presbyteries would probably not agree to this, as it would inflict on them the same hardships the Lexington Presbytery was trying to escape.

108“"Report Concerning the Division of the Lexington Presbytery," 421; "Division of Presbytery" from Minutes of the Winchester Presbytery, quoted in Minutes of the Lexington Presbytery, 1911, 516. By "church-organizations," the presbytery meant a local ecclesiastical unit served by a single pastor. These could consist of one congregation, as in the case of Elkins, or two or more congregations, such as Beverly/Midland, Davis/Thomas, or Hambleton/Parsons/Hendricks.
} 
total membership. The Lexington Presbytery also requested that the Synod of Virginia make special financial provision for the Presbytery of Tygart's Valley, which would help the new body survive and ensure that it would be an organic part of the Synod, and not just a colony of the existing presbytery. ${ }^{109}$

The Synod wasted no time. That year, 1911, it erected the Presbytery of Tygart's Valley, which included all or parts of fourteen West Virginia counties. ${ }^{110}$ The Davis rail network tied these counties together, making travel relatively easy. Because it was not linked to the others by rail, Pendleton County remained in the old presbytery. In its haste, however, the synod neglected to provide financial support for the new presbytery. Thus, the mother and daughter bodies decided to delay the split, as most of the churches within the bounds of the new presbytery were not financially independent. Should the new presbytery convene, it would be completely unable to provide for most of its congregations. A year later, the synod approved the necessary funding, and the Presbytery of Tygart's Valley held its first meeting at Davis Memorial Presbyterian Church in Elkins. ${ }^{111}$

The new presbytery represented important changes taking place in Southern Presbyterianism. First, to a large extent, the Presbytery of Tygart's Valley owed its existence to the railroad, specifically the Davis rail system. The most prosperous churches within its bounds were in the mountains and along the WVC\&P. Half of those congregations had existed barely

\footnotetext{
${ }^{109}$ "Report Concerning the Division of the Lexington Presbytery," 422, 424; "Overture to Synod of Virginia as to Division of Presbytery," excerpted from Minutes of the Lexington Presbytery in Minutes of the Presbytery of Tygart's Valley, 1912, 14.

110“Action of the Synod of Virginia, 1911," excerpted from Minutes of the Synod of Virginia in Minutes of the Presbytery of Tygart's Valley, 1912, 18; Howard McKnight Wilson, The Lexington Presbytery Heritage: The Presbytery of Lexington and its churches in the Synod of Virginia, Presbyterian Church in the United States (Verona, VA: McClure Press, 1971), 128, 129.

111“Action of the Synod of Virginia, 1912," excerpted from Minutes of the Synod of Virginia in Minutes of the Presbytery of Tygart's Valley, 1912, 19; Allen 33.
} 
ten years, yet their prosperity already exceeded that of many churches two, three, and even four times older. Natural resources were not the only cause of this, or perhaps even the primary cause. The vast interior of the state also contained rich timber and coal lands. Yet churches in those counties, both old and new, continued to struggle as their sister congregations in the highlands prospered.

Rather, the mountain churches reaped the benefits of an elite membership. Industrialization had turned Randolph and Tucker counties, along with other counties in the Alleghenies, into strongholds of the new economic order. Regional capitalists such as Henry Gassaway Davis and Stephen B. Elkins, along with their local power brokers and agents, belonged disproportionately to Presbyterian churches. These men, believing strong churches to be foundational to a strong West Virginia and strong America, gave generously to their houses of worship.

Second, the creation of the Tygart's Valley Presbytery signaled the end of an era for the Synod of Virginia. The territory opened by the railroad proved somewhat fertile ground for the Presbyterian message, at least in terms of the number of churches established. Indeed, all of West Virginia, once essentially an outpost of the Synod of Virginia, had blossomed into a stronghold of Southern Presbyterianism. New methods of transportation notwithstanding, the size and terrain of the newest presbytery, not to mention the rest of West Virginia, made overseeing, coordinating, and unifying the synod from east of the mountains increasingly difficult.

More specifically, the creation of the Tygart's Valley Presbytery meant that, for the most part, the churches within the synod were divided into presbyteries according to their state. The Greenbrier, Kanawha, and Tygart's Valley presbyteries contained only West Virginia churches. 
The Presbytery of Winchester remained the only presbytery in the entire synod with both Virginia and West Virginia churches. In response to denominational expansion in West Virginia and the resulting re-organization, the Greenbrier, Kanawha, and Tygart's Valley presbyteries began demanding a new synod. They all overtured the Synod of Virginia in 1913 to join with them in petitioning the General Assembly to combine those three into a synod consisting only of churches in West Virginia. $^{112}$

The Synod of Virginia agreed, and the following year it petitioned the General Assembly of the PCUS to form the three petitioning presbyteries as the Synod of West Virginia. The General Assembly assented, and the new ecclesiastical body planned to hold its inaugural meeting in the fall of $1914 .{ }^{113}$ The formation of the new synod indicated not just the numerical success of Presbyterianism in the mountains, but also the long-term viability of those churches. Just two years before, when the Tygart's Valley Presbytery formed, the overwhelming majority of its churches did not enjoy financial independence. Of course, this situation did not reverse itself in two years, but the fact that the Synod of Virginia and the General Assembly approved of the creation of the Synod of West Virginia showed that the presbyteries, especially Tygart's Valley, developed an effective system of support for weaker churches. The Synod of Virginia, the Presbytery of Lexington, and even the General Assembly continued to help with financial resources for churches in the Tygart's Valley Presbytery, but the churches within that group, along with churches across West Virginia, quickly made significant strides in providing for themselves. $^{114}$

\footnotetext{
${ }^{112}$ Minutes of the Presbytery of Greenbrier, 1914, 17. The terms "overture" and "petition" were the official terms used to refer to formal requests from one denominational level to a higher one.

${ }^{113}$ Minutes of the Presbytery of Greenbrier, 1914, 17, 18.

${ }^{114}$ Allen, 53.
} 
The Davis Memorial Presbyterian Church in Elkins, the largest church in its presbytery and the largest in the mountain counties, took the lead in aiding feeble congregations and encouraging missionary activity throughout the region. Installed as pastor by the Lexington Presbytery in early 1902, the Reverend Frederick Barron helped lead the way in strengthening local churches. Davis Memorial had been struggling over the previous few years, but under his leadership the church quickly prospered. Rev. Barron had been instrumental in forming the Tygart's Valley Presbytery, which itself was the result of church growth in the area. After that development, he served on the presbytery's Home Mission Committee, often as chair, until he relocated to Charleston to head a financial campaign for denominational educational institutions. $^{115}$

Such local work was necessary. The Synod of West Virginia did not centralize and organize its missions and evangelism to the same extent as its mother synod had. It did establish a Synod's Home Mission Committee, which, like its counterpart in the Synod of Virginia, was comprised of the chairmen of the presbyterial mission committees and two at-large members. Into the 1920s, this group oversaw funding for all denominational organizations and activities, except for its schools and orphanage. Thus, in its early years, home missions was just one of many tasks for which the committee was responsible. ${ }^{116}$

The committee attempted to establish a missionary apparatus that mirrored the one with which the presbyteries were accustomed from their tenure in the Synod of Virginia. However, West Virginia’s plan resembled Virginia’s 1890 synodical mission plan, not the 1902 reorganization which had significantly increased central control over missions. The Synod of West

\footnotetext{
${ }^{115}$ Ross, 32, 44, 45; Allen, 21, 57, 58.

${ }^{116}$ Allen, 62, 64.
} 
Virginia did not appoint a single superintendent of missions over the entire territory, nor did it centralize all missionary activity under a single entity. Rather, West Virginia's home mission committee focused only on spiritually destitute areas to which the presbyteries could not tend. The synodical committee was very clear it would not encroach on presbyterial mission work. Like the Synod of Virginia between 1890 and 1902, West Virginia's committee would supply evangelists and money to the presbyteries, but only upon request, and the presbyteries would direct the evangelists' work. ${ }^{117}$

It is difficult to assess the impact, or lack thereof, of this decentralized plan on the mountain counties. Few sections of the mountains remained completely closed at the establishment of the new synod. Thus, between 1910 and 1920, Mineral, Tucker, and Pocahontas added no new congregations. However, the coal and, especially, the timber boom lasted long enough to continue to draw people into the region, and an extensive rail network could take them just about anywhere. A number of tiny communities continued to spring up in those counties, mostly in Randolph and Grant, which added three and four churches respectively. $^{118}$

\section{Conclusion: Elitism and Popular Religion}

By 1920, forty years after H.G. Davis established his West Virginia Central and Pittsburg Railway, the presence of Presbyterianism in the mountains increased nearly fourfold. Five onceremote mountain counties of West Virginia contained forty such congregations, up from just fourteen in 1880. The Southern Presbyterian Church established all of the new ones, and all of the pre-existing ones belonged to the PCUS. The specific denominational affiliation of those

\footnotetext{
${ }^{117}$ Allen, 62-64.

118“Statistical Reports," Minutes of the General Assembly of the Presbyterian Church in the United States, 1920, 273-276.
} 
churches, especially the new ones, signified a commitment to conservative theology. ${ }^{119}$

It also meant Presbyterianism was hardly the church of the outsider. While the Synod of Virginia and its constituent presbyteries sent missionaries into the mountains, those men did not bring a foreign religion. Religious scholars H. Davis Yevell and Marcia Clark Meyers note that Presbyterians conceived of the home mission movement in the late nineteenth century "as a means for assimilating 'exceptional populations' into the American mainstream." ${ }^{120}$ They wanted to use the gospel to unite the country under the banner of Protestantism. However, the two major wings of the denomination understood the details of this endeavor in different ways. Northern Presbyterians believed the mountain people needed to be uplifted and civilized. They needed to catch up to the rest of the country in many ways, but especially culturally. ${ }^{121}$

On the other hand, as the mission to the mountains of West Virginia indicated, Southern Presbyterians saw the church as a bridge between two groups that shared much in common. The congregations that pre-dated industrialization already embodied the values that Victorian society cherished because Presbyterianism itself held those values in high regard, finding support for them in Scripture. As the records of the synod and presbytery revealed, newer churches

\footnotetext{
${ }^{119}$ State-wide, the General Assembly reported approximately 15,782 Southern Presbyterians in 1920. This number is approximate, as not all counties in the state were in the Synod of West Virginia. This number does include the churches in the Presbytery of Winchester, in the Synod of Virginia. However, that presbytery included churches in Maryland as well. In any event, this rough figure demonstrates the fact that while the denomination expanded its reach in terms of the number of churches, its growth in the state over the Gilded Age and the Progressive Era was actually small. The PCUS added just about 5000 members in forty years. It remained the third largest Protestant denomination in the state (fourth when the MEC and MECS are considered separately). See "Statistics," Minutes of the General Assembly of the Presbyterian Church of the United States, 1920, 260-273. The PCUSA reported 6175 members around the same time. "Statistics of the Synod of West Virginia," Minutes of the Synod of West Virginia, 1917, n.p.

${ }^{120} \mathrm{H}$. Davis Yevell and Marcia Clark Meyers, "The Presbyterians in Central Appalachia," in Christianity in Appalachia: Profiles in Regional Pluralism, Bill J. Leonard, ed. (Knoxville: The University of Tennessee Press, 1999), 191.

${ }^{121}$ Yevell and Meyers, 191, 192.
} 
continued to embrace those same virtues. ${ }^{122}$ Many of these shared values pertained to authority. The new industrial order prized discipline and obedience to a pre-ordained hierarchy. The new elites, and the agrarian elite allies, expected their subordinates to do as they were told and to delegate authority and duties as needed. Managers, in turn, expected clerks and laborers to be prompt, stay on task, and work efficiently. Time was money, and a stoppage anywhere along the line meant lower profits and lower pay. ${ }^{123}$

Presbyterian denominational structure functioned in a similar fashion. While individual congregations possessed the autonomy to elect their own leaders, call their own pastors, and run their day-to-day affairs, higher levels of ecclesiastical authority held certain expectations, perhaps chief among which were doctrinal. Through the 1920s, Southern Presbyterians at all levels continued to adhere to traditional understandings of the Bible (see chapter 7 for more on this) and of the spirituality of the church. Furthermore, as in industry, the average parishioner had little chance to exercise much power or to rise through the ranks. To be fair, he probably had more freedom than did laborers. Presbyterians voted on elders and deacons; coal miners and timber workers did not have the privilege of electing foremen or managers. Elders and deacons served for life, and theirs were usually the only offices in many congregations, especially the smaller ones. Thus, fewer members had the chance to serve. The average parishioner could certainly rise through the ranks and become elder or pastor, but, as was the case with the common laborer in mechanized industry, he was increasingly becoming the exception rather than the rule. ${ }^{124}$

\footnotetext{
${ }^{122}$ Thomas J. Schlereth, Victorian America: Transformations in Everyday Life, 1876-1915 (New York: HarperPerenial, 1991), 65, 66, 243-269. See also Robert T. Handy, A Christian America: Protestant Hopes and Historical Realities (New York: Oxford, 1984).

${ }^{123}$ Schlereth, 54-67.

${ }^{124}$ Schlereth, 56.
} 
These similarities between Presbyterianism and industrial capitalism could help to explain the close association between secular elites and that denomination. As church records show, in the West Virginia mountains the upper class belonged disproportionately to this group, but, as the records also reveal, Presbyterian churches were among the most socially diverse congregations in the region. They were all overwhelmingly white and native born, but they came from all walks of life. Thus, in some regard, Southern Presbyterianism represented popular religion as well.

Identifying elements of popular religion in these Presbyterian churches is a bit more difficult than doing so in Baptist churches and Methodist churches. Unlike Baptists, individual Presbyterian congregations did not draft distinct doctrinal statements; unlike Methodists, Presbyterian churches had very few available leadership opportunities for lay members. Like these two denominations, Presbyterians in West Virginia held revivals, which, as religious scholar Charles Lippy observed, "centered on the awesome reality of the supernatural that came directly to the believer through the intense, personal experience of conversion." ${ }^{125}$

Presbyterians played a key role in fomenting the Second Great Awakening, but their participation did not last long, as ecclesiastical authorities feared the camp meetings would disrupt proper order and erode proper doctrine. Presbyterians in the South, who tended to be more traditional, thereafter shied away from the movement, while their Northern counterparts continued to embrace it, most notably traveling evangelist Charles Grandison Finney ${ }^{126} \mathrm{~A}$ century later, however, Southern Presbyterians in West Virginia were comfortable with

\footnotetext{
${ }^{125}$ Charles H. Lippy, Being Religious, American Styles: A History of Popular Religiosity in the United States (Westport, CT: Praeger, 1994), 76, 77.

${ }^{126}$ Roger Finke and Rodney Stark, The Churching of America, 1776-2005: Winners and Losers in Our Religious Economy (New Brunswick, NJ: Rutgers University Press, 2005), 89-92, 108-112.
} 
revivalism. At times their revivals employed techniques pioneered much earlier, such as the anxious bench, where attendees could get special prayer as they struggled, often very emotionally, with their sin. The Progressive Era revivalists, like their predecessors, focused on the individual, "enticing men [and women] into the good way" by somehow simultaneously appealing to each listener individually and to no one in particular. ${ }^{127}$

Despite the denomination's emphasis on preserving its identity, Southern Presbyterians exhibited willingness to work with other denominations and focus on commonality. For evangelical Protestants, the great commonality was personal conversion. The message preached by the Rev. George Stephens, one of the revivalists sponsored by the Keyser Presbyterian Church, focused on the personal and the supernatural. While it is difficult, if not impossible, to say why a given person joins a given church, by supporting events such as the Stephens Revival, Presbyterians communicated a message of personal religion to potential adherents. While their denomination possessed a rigid power structure, it by no means precluded direct connections between rank-and-file members and the divine. Rather, it actively encouraged them developments.

A few quotes from Rev. Stephens demonstrate the expectation of a supernatural occurrence at these meetings, and for the believer in everyday life. "The need is universal, everybody must be born again." "You don’t put on Christianity. It means Christ in you." "God knows your heart, no matter how nice you think you are."128 Clearly anyone, regardless of birth, or rank, or color could have an intimate relationship with God that was not bound, regulated, or limited by any other authority.

Presbyterians in the mountains of West Virginia continued to hold firm to this deeply

\footnotetext{
${ }^{127}$ Finke and Stark, 97; “The Campaign Begins Sunday Night 7 O’Clock,” Keyser Daily News, Feb. $19,1917$.

${ }^{128}$ People Are Thinking About Their Souls,” Mineral Daily News, Feb. 24, 1917.
} 
personal approach to religion, something that was consistent with the historic Presbyterian message, while insisting on the order and discipline which also characterized their faith. In doing so, they appealed to a broad spectrum of the public, and in some cases seemed to encourage the upper class to join their ranks. Between 1880 and 1920 they succeeded in holding popular religion and ecclesiastical hierarchy in tension. The equilibrium they achieved also showcased the cultural connections between modern mainstream America and an industrializing rural region. Along with the Baptists and the Methodists, the Presbyterian Church acted as a pier for a cultural bridge between these two parts of the country, the deck of which consisted of a number of shared cultural assumptions. Unlike the two former groups, the Presbyterian Church in the Alleghenies functioned as cultural liaison for secular elites, facilitating the forging of bounds between incoming capitalists and the existing power structure. It performed so well in both these roles precisely because of its presence in the area prior to 1880 and its continued commitment to an orthodox faith. 


\section{6: Baptists}

\section{Cooperation, Not Subordination}

In 1883, the Executive Board of the Baptist General Association of West Virginia realized that it must take advantage of the new railroads crisscrossing the state if Baptists were to reach effectively the growing population of the state. The Board declared that, "The rapid development of State by railroads, building or projected, the rapidly advancing agricultural and mining interests constantly opening up new and important fields, inviting us to occupy them these things cause us to exclaim, 'Oh, for the Spirit's awakening power in our ministry and among our churches." ${ }^{1}$ Over the course of the 1880 s, the denomination worked diligently to evangelize portions of the state, with little to no Baptist presence.

The Allegheny region, especially its western face, was one of the most destitute regions in the state for Baptists. Unlike the situation of the Presbyterians and Methodists, Baptist work in the mountain counties began almost from the ground up. Their work in the region demonstrates popular religion in ways that are intricately connected to denominational distinctiveness. The lack of Baptist presence prior to industrialization makes it more difficult to set the religious life of Baptists in that area in a national context. The nature of Baptist life in the Alleghenies prior to industrialization cannot be compared to life during and after industrialization, simply because it did not exist. However, Baptist mission and church work in the area during the Gilded Age and Progressive Era does show that new Baptist churches were remarkably similar to those already existing elsewhere in West Virginia. Throughout that period, most West Virginia Baptists fellowshipped with Baptists across the county; yet even as national mainstream Baptist life changed, Baptists in the state, including those in the mountains, maintained traditional Baptist

\footnotetext{
1“'Executive Board Report,” Minutes of the Baptist General Association of West Virginia, 1883.
} 
understandings of polity and theology.

By the late 1880s and early 1890s, Baptists established a presence in the Alleghenies. Mission efforts and church growth reflected a commitment to historic Baptist principles, but development was slow and uneven into the first two decades of the twentieth century. While the Baptist General Association worked feverishly to evangelize the Alleghenies, it quickly realized its resources were unequal to the task. Missionary efforts in many places, even in some wellestablished commercial centers, were inconsistent and under- funded.

For the first two decades of its existence, the Baptist General Association of West Virginia was nominally and unofficially affiliated with national Baptist organizations. It consistently supported foreign missions through donations to the American Baptist Missionary Union (part of what became the Northern Baptist Convention in 1908) and also made occasional donations to the Southern Baptist Convention for the same purpose. ${ }^{2}$ In 1865, the General Association, recognizing the spiritual need in the state, recommended that local churches that needed additional funding apply to "whatever Regular Baptist Missionary organization they may see fit." ${ }^{3}$ Generally, Northern Baptists exhibited greater concern for the new state at that time than did Southern Baptists.

This work was not officially connected or coordinated with the work of the state Baptist General Association, nor did the BGA support the American Baptist Home Mission Society (another body which would become part of the Northern Baptist Convention) or any other national domestic mission group financially or in any other way during the immediate post-war period. Thus, while there was some work by national denominational groups, it was limited in

\footnotetext{
${ }^{2}$ Sixty-Fifth Annual Report of the American Baptist Missionary Union (New York: ABMU, 1879), 7, 8.

3 "Resolutions," Minutes of the Baptist General Association of West Virginia (Parkersburg, WV: Sentinel Publishing, 1878), 9.
} 
scope and aimed at particular local churches desiring immediate assistance. West Virginia Baptists as a whole continued to remain independent vis a vis home (state) missions, sending out their own missionaries into destitute portions of the state and making decisions exclusively at the local and general association levels. In 1886 they formally joined the American Baptist Home Missionary Society, although their reasons for doing so are unclear. According to the Association records, there was much discussion on the issue. Elsewhere in the minutes the Executive Committee lamented about the persistent shortage of resources with which to carry out missionary endeavors. ${ }^{4}$

No specific details pertaining to the decision to join the American Baptist Home Missionary Society were reported until the 1915 Jubilee meeting, and even then the account gave just an overview of the events that took place at the 1886 annual meeting in Huntington. Reminiscences indicated that representatives of the SBC and the ABMU presented their cases to the assembly. Some West Virginia Baptists who wanted to join with the SBC, and those in Virginia, desirous of closer relations with their West Virginia brethren, also encouraged a shift toward the SBC. The Reverend Dr. H.A. Tupper spoke for the Southern Baptists, and impressed his audience, especially about the work of the Convention in Mexico. Then the Rev. Thomas Allen of the ABMU spoke. According to recollections, "He carried his hearers... and when he had finished, the address of Dr. Tupper had been forgotten.",5

The BGA provided no other details about the merits of joining with Northern Baptists; however, the records of the Southern Baptist Convention may shed more light. They also indicate that while the actual decision may have been made in 1886, the issue had been brewing

\footnotetext{
4"Executive Board Report," Minutes of the Baptist General Association of West Virginia (Parkersburg, WV: Sentinel Publishing, 1886), 16-18.

${ }^{5}$ Arthur Hank, A.B. Withers, and John S. Stump, eds., Baptist General Association of West Virginia: Jubilee Volume (s.1.: 1915), 68, 69.
} 
for several years. In 1882, the Reverend Matthew Ellison, the Convention's Vice-President for West Virginia, enumerated four reasons why he thought West Virginia would not join the SBC, but would rather unite with the ABMU. The first was relational in nature. Northern Baptist groups had been reaching out to and working in West Virginia since before the Civil War. The Southern Baptist Convention, by contrast, had little contact with West Virginia until more than a decade after the war. Beginning in 1877, the Southern Baptist Convention counted the BGA of West Virginia as a constituent body, although no delegate attended its gathering. In fact, while there were many "Visiting Brethren" at SBC meetings over the next two decades, only one official delegate from the BGA attended a convention between 1877 and 1899, when West Virginia was finally removed from the rolls. During that time, at least one SBC missionary served the state each year, but usually they were confined to the border counties, specifically in the southeast. ${ }^{6}$

The second and third reasons pertained to the financial strategies of both the ABMU and the ABHMS. The ABMU would impose less of a financial burden for foreign missions on West Virginia Baptists than would the SBC. In addition, the ABHMS would provide dollar-for-dollar matching funds for in-state mission work, and the Home Mission Board of the SBC could not compete with that. The fourth reason was the only one relating to sectional differences. American Baptists, Ellison noted, believed there was no reason for another national Baptist group to exist anymore, "the cause originating the Southern Baptist Convention being swept away by the war."

\footnotetext{
6"Relations of State Boards and Convention," Annual of the Southern Baptist Convention, 1882, 57; Hank, 46; Annual of the Southern Baptist Convention, 1877, 10; Annual of the Southern Baptist Convention, 1884, 5; "Appendix B," Annual of the Southern Baptist Convention, 1899, LXXIV; Hank, et. al. "The American Baptist Home Mission Society - Fifty Years Work in West Virginia, 190.

7“"Relations of State Boards and Convention," 57.
} 
West Virginia Baptists clearly desired cooperation, but not at the expense of autonomy. The General Association held the ABHMS in high regard, declaring that it was "a denominational necessity," but the resolution that passed in favor of uniting with that national group specified that the Executive Board would not permit the national group to take over state missions. Autonomy would be preserved. The General Association, the Executive Board insisted, would cooperate with the American Baptist Home Mission Society "provided, our distinctive State Mission work under the management of the Board shall not be abandoned." 8 In practice, this amounted to receiving some money and missionaries from the national body, but once in West Virginia, all funds and personnel came under the direction of the state association and its Superintendent of Missions and would be spent on work in fields selected by the state body. This polity, which emphasized a balance between autonomy and cooperation, extended to the local level as well. ${ }^{9}$

This fierce protection of independence is reflective of the traditional Baptist understanding of local church autonomy. Joining with the Northern Baptists instead of the Southern Baptists may have been the best way to both protect autonomy and yet still further the work of Baptists in West Virginia. During the second half of the nineteenth century and extending into the early twentieth century, Northern Baptists were far more decentralized than their Southern counterparts. Four major societies carried out Northern Baptist work - the American Baptist Missionary Union, formerly known as the Triennial Convention and devoted solely to foreign missions; the American Baptist Home Mission Society; the American Baptist Publication Society, formerly known as the Tract Society; and the American Baptist Education

\footnotetext{
8“Executive Board Report,” 1886, 18.

9"Report on Home Missions" and "Resolution on Cooperation," Minutes of the Baptist General Association of West Virginia (Parkersburg, WV: Sentinel Publishing, 1889), 18, 23.
} 
Society, which also included Southern Baptists. All were independent of each other. There was no single organization for all Northern Baptists. The Southern Baptist Convention, on the other hand, was in charge of both home and foreign missions, as well as other aspects of Southern Baptist life, although the Convention still did not have legislative or judicial power over constituent state or local groups. ${ }^{10}$

The process of recruiting West Virginia demonstrates that reality. Rev. Allen represented the Missionary Union, but the Baptist General Association of West Virginia voted to cooperate with the Home Mission Society. This could indicate that West Virginia Baptists had closer ties to the ABMU than to the ABHMS, a conclusion strengthened by the fact the General Association had been financially supporting the foreign missionary society, yet not supporting the home missionary society. It also shows that decentralized authority and local church autonomy were important to both West Virginia Baptists in particular and Baptists in the North in general. At the same time, a spirit of cooperation was encouraged and cultivated among the various societies of Northern Baptists and affiliated state and local bodies. Prior to 1888, the ABHMS grouped West Virginia with Pennsylvania as one missionary district. Once West Virginia joined the national group, the state became its own district, alternately called the West Virginia District or the Kanawha District. The Reverend W.E. Powell, the General Missionary and Superintendent of Missions for the BGA, was appointed as the state's representative to the society. In his first report to the national society's board, Powell noted that the spread of the railroad and the rapid increase in population and new towns made it impossible for the BGA alone to evangelize the

\footnotetext{
${ }^{10}$ McBeth, 393-413.
} 
state effectively. It had done and continued to do good work, but assistance from the ABMHS was necessary. ${ }^{11}$

\section{Baptists in the Mountains}

Baptists had significant challenges ahead of them. The first detailed, organized mission report did not appear in General Association records until 1881. ${ }^{12}$ In 1889 , the group reported “alarming destitution" in nearly thirty counties, including Mineral, Grant, Tucker, Randolph, and Pocahontas. ${ }^{13}$ Yet it saw great potential. The West Virginia Central and Pittsburg already connected five of these six counties, and another road was being laid to Marlinton in Pocahontas County. "It is worth much to that denomination of Christians who can and will put the first missionaries to work on along the lines of new railroads," the Executive Board observed. ${ }^{14}$ Baptists particularly stressed the importance of occupying county seats.

Such optimism was justified. Soon after joining the ABHMS, state missions took off. In 1885, there were 447 churches in the state, and just eleven missionaries. Ten years later, the number of missionaries had increased to eighteen, but the number of congregations jumped to 525. ${ }^{15}$ Between 1883 and 1892, the total number of Baptist parishioners increased from approximately 26,000 to just over 34,000 . By the turn of the century, Baptist bodies affiliated with the state and national organizations counted more than 40,000 members. Over the next two decades the denomination experienced steady growth. By 1919, Baptists claimed more than

\footnotetext{
11،Annual Report of the Board," Fifty-Sixth Annual Report of the American Baptist Home Mission Society (New York: ABMHS, 1888), 44, 45.

${ }^{12}$ Hank, et. al., "Fifty Years of State Mission Work in West Virginia," 50.

13،"Report on State Missions," Minutes of the Union Association, 1889, 4.

14“"Unoccupied Fields,” West Virginia Baptist Annual: Proceedings of the General Association, $1892,13$.

15“"Executive Board Report," Minutes of the Baptist General Association of West Virginia (Parkersburg, WV: Sentinel Publishing, 1904), 13.
} 
61,000 white members and 15,000 blacks, making them the second largest Christian denomination in the state. ${ }^{16}$

Improved transportation and increased in-migration provided missionaries with fertile ground and better ways to reach it. Even missionary efforts within the remote mountain counties along the WVC\&P mainline looked at least somewhat promising. Keeping missionaries and churches in these areas was extremely difficult, even with the railroad and the constant influx of new people. With help from the national home mission society, the Baptist faith slowly began to grow in the highlands. Several Baptist churches took root along the Allegheny front by 1900, most of which were scattered along the railroad tracks that cut through the peaks and slopes. Baptists maintained a continuity of faith and practice in West Virginia, even in a rapidly changing world. Not only had the General Association retained its autonomy while adapting to the times, but new local groups also exhibited the same dedication to traditional Baptist polity and theology as older churches in the area. Although records for these congregations are sparse, they indicate respect not only for local church autonomy and associationalism, but also for other Baptist distinctiveness, including egalitarian polity and theology and respect for confessional faith. Baptists valued written statements of belief, but those were specific representations of local congregations, not rules determining which individual churches could and could not be Baptist. This consistency also informed how Baptists related and responded to the changes occurring in the secular sphere, and thus also played a role in how West Virginia became

\footnotetext{
16“"Statistical Table," Minutes of the Baptist General Association of West Virginia (Parkersburg, WV: Sentinel Publishing, 1883), n.p.; "Summary of Statistics," 1892, n.p.; "Statistics of the Baptist General Association of West Virginia," 1919, n.p.; Hank, et. al. 54. These numbers roughly correspond to those found in the United States Census around the same time. According to the 1926 survey of religious bodies, Northern Baptists numbered nearly 77,000. Southern Baptists counted just over 3,500, with Primitives numbering about 1,300. See Religious Bodies: 1926, vol. 2 (Washington: United States Government Printing Press, 1929), 81, 85, 196.
} 
increasingly connected with and integrated into the mainstream of America over the course of the Gilded Age and Progressive Era.

West Virginia Baptists received help from more than just the American Baptist Home Mission Society. Virginia Baptists took an avid interest in evangelizing their western neighbors during the last quarter of the nineteenth century. Their actions, however, did not constitute cooperation among the Baptists of the two states. The various Virginia Baptist associations that sent missionaries into the West Virginia border counties always intended for new churches to unite with Baptist associations in Virginia, not West Virginia. In 1881, the Potomac Baptist Association sent a Reverend Umstot into West Virginia's eastern panhandle and he formed a church in Wardensville in Hardy County almost immediately. The next year that church and a few others in the panhandle formed the Shenandoah Association, which then joined the Baptist General Association of Virginia. This new association aimed to foster closer communion among churches "west of and immediately adjacent to the Blue Ridge" and to establish new churches in “this neglected part of the vineyard."17

Rev. Umstot continued to labor their, taking into account the presence of the railroad but perhaps not utilizing it to his greatest advantage or in the way West Virginia Baptists would have preferred. By 1886, the West Virginia Central and Pittsburg had reached Tucker County. Rev. Umstot formed a Baptist church in Mineral County that year, but it was not in Keyser, near the northern terminal of the railroad. The new church, Mineral Baptist Church, began at his home in Patterson Creek, several miles northeast of Keyser near the Maryland border. Umstot was the pastor, and the congregation consisted of seven members: five women and two men. For the first two years, the group met in schoolhouses and private homes. It then acquired an existing

\footnotetext{
17"Preamble and Resolution," Minutes of the Meeting of the Formation of the Shenandoah Baptist Association (New Market, VA: Henkel \& Co. Printers, 1882), 1.
} 
structure to use as a meeting house, which became known as the Old Baptist Church, located near the pastor's home. The congregation, however, continued to be called the Mineral Baptist Church. In 1888, a new church was formed, the Lone Star Baptist Church near Burlington, about twelve miles southeast of Keyser.. The Lone Star church was the home building of the congregation, but the body met in several locations in Mineral County, including at the Old Baptist Church. Mineral Baptist also served parts of neighboring Hampshire County. ${ }^{18}$

The small group drew up an eleven-article confession of faith similar to other Baptist confessions in use at the same time. The Old and New Testaments were described as "the word of God and divinely inspired and a revelation from God to man." While basic, the articles on salvation reflected careful theological consideration which attempted to navigate a middle passage between strict Calvinist predestination and free will Arminianism. In fact, the language suggested a greater understanding of theology than of English grammar. While the grammar was poor, the religious articulation was careful. The atoning work of Christ on the cross was "as universal as the curse." Redemption, however, was conceived of as particular, while at the same time based on repentance and belief. Only those sinners who repented and exercised a "living and divine faith in the atoning blood of Christ" would be saved. All true saints would persevere to the end and receive a final reward in heaven. Unbelievers, however, would spend eternity separated from God in hell. ${ }^{19}$

Church records shed light on how the congregation understood those tenets. The pastor and the members applied the doctrinal positions in specific ways in the everyday life of the church. Minutes indicate that after preaching, the pastor would invite those who had been saved

\footnotetext{
18“Minutes," Mineral Baptist Church, 1886-1888, 8-15; 1890, 21. In 1890, a separate congregation was formed in Hampshire County at Mechanicsburg. Eleven members left Mineral Baptist to form this new church.

19 “Minutes," Mineral Baptist Church, 1886, 6-8.
} 
to join the church. For example, in April 1889, he requested all those come forward "who Believed the Lord had Bin gracious to them in the pardon of theirs sins and desired to unite with the Mineral Baptist Church By Baptism."20 There are similar examples of these calls to listeners come forward, confess faith, and join the church. The phrasing indicates the conviction that God must forgive sin, but that the individual must believe in Christ and accept the pardon. Since the local church included regenerate believers only, the next logical step for a new convert was to become a member of a local body. Because the means of joining was baptism, the next step for one wishing to join was to be baptized.

The statement is also very specific about ecclesiology. Not only was baptism by immersion the only mode taught in the Bible, but "such a baptism is essential to our membership with a scriptural church." Three articles pertained to church life. Members pledged themselves to the work and success of the church. The statement was not only an expression of beliefs, but also a covenant in which signatories affirmed that they were "willing to be ruled by the word of God and that the majority of the members shall rule according to the word of God."21

While brief, the statement encapsulates several historical Baptist doctrinal distinctives. Baptism was more than just being immersed; it was the door to the local church. Congregational church government and local church autonomy also featured prominently. Finally, the confession demonstrated the continued struggle of Baptists to chart a clear and consistent course on salvation that remained faithful to a sound, straightforward, and literal reading of Scripture while not becoming dry, doctrinaire, and discouraging of mission work.

This church represented the decentralized nature of Baptist organization as well as some organizational fluidity. Upon formation, it was technically an independent Baptist church,

\footnotetext{
20“Minutes," Mineral Baptist Church, 1889, 16.

21،"Minutes," Mineral Baptist Church, 1886, 6-8.
} 
formed by independent, individual believers, but then it requested association membership and was "read into the Shenandoah Association." Upon joining, members consented to the Constitution of that association, much of which was similar to the Mineral Baptist Church statement of faith. "The Word of God, in the Old and New Testaments, is the only true and proper standard of Christian faith and practice...”, the association and its constituent churches maintained. The Bible concentrated "all executive [and] ecclesiastical authority in each separate congregation of baptized believers." 22

The association was the primary unit of Baptist denominational organization. Local church autonomy did not mean isolation, and historically most Baptists balanced cooperating with other churches with the freedom to run their distinct congregations as they saw fit, without outside interference. $^{23}$ Despite the size and resources of national, or at least regional, groups such as the Southern Baptist Convention and the American Baptist Home Mission Society, significant missionary and benevolent work occurred at the association level. The very existence of the Shenandoah Association and several of its constituent churches, including Mineral Baptist, evince this fact. At the same time, however, membership in the association was voluntary and did not require relinquishing local church autonomy.

The Constitution of the Shenandoah Association expressly stated that churches uniting with it would not surrender their independence. Furthermore, the association could not "exercise any control over the internal affairs of the churches, or arraign any church at her bar for any purpose whatever." While this left member churches free to conduct affairs as they pleased, it did not mean that just any church would be welcome to fellowship under any circumstances.

\footnotetext{
22،"Constitution," Minutes of the Meeting of the Formation of the Shenandoah Baptist Association, 5.

${ }^{23}$ Bill Leonard, "Conviction and Contradiction: Reassessing Theological Formation in Baptist Identity," Baptist History and Heritage 47 (Summer 2012), 12.
} 
The association reserved for itself the right to exclude churches from membership "for any defection deemed sufficient." ${ }^{24}$ The Constitution gave no specifics about what a sufficient defection might be, but usually a church was dis-fellowshipped for serious doctrinal error or misconduct. Very rarely did failure to give adequate financial support to the association result in expulsion.

In 1889, Mineral Baptist dispatched a delegation to form the Eastern Association with three other churches in West Virginia's Eastern panhandle. The new association organized "at the old Baptist church ... in Mineral County" on July 27, 1889. The new group held its first session near Petersburg in Grant County in September of that year. Only two West Virginia churches, one in Martinsburg and one in Charles Town, remained in the Shenandoah Association. ${ }^{25}$ The new association outlined a broad, three-fold purpose: "the preaching of the word of God, the conversion of sinners, and the building up of the Redeemer's Kingdom, at home and abroad."26

The Constitution for the Eastern Association was very similar to that of the Shenandoah Association. Constituent churches surrendered none of their independence, and the association would function neither as a legislative or judicial body. However, churches wishing to join did have to agree on some basic points, which mirrored the confession of Mineral Baptist and its former association. First and foremost, congregations affirmed "that the word of God in the Old and New Testament is the only true and proper standard of Christian faith and practice...” In keeping with classic Baptist faith, the local church of baptized believers retained all "executive and ecclesiastical authority." The association and its constituent bodies asserted that these

\footnotetext{
${ }^{24}$ Leonard, "Conviction and Contradiction," 6.

25“"Minutes," Mineral Baptist Church, 1889, 19, 20; “Minutes,” Shenandoah Association (New Market, VA: Henkel \& Co, 1888), 7 .

26“"Constitution and By-Laws," Minutes of the Eastern Association, 1890, 4.
} 
doctrines and others "generally believed and taught by Baptists in West Virginia, and of the United States, are in accordance with the word of God."27

This congregation struggled. For its first fifteen years membership barely exceeded thirty. At no time from its beginnings through 1920 did it have more than fifty-three members. ${ }^{28}$ Reasons for the low numbers are unclear. While, historically, Baptists had no presence in the county, Rev. Umstot did his best to spread the Baptist message. The charter members were a homogeneous group. Both male members were farmers. One owned his farm, the other did not, and was unemployed for a time. Most of the women were farmers' wives. ${ }^{29}$ In November of 1887, the pastor preached a revival at the Lone Star Church, and eight people joined the church as a result. The converts comprised a slightly more diverse cross-section of society. Of the three male converts, one was railroad yardmaster and one was a mail carrier, but as before, the women were farmers' wives. ${ }^{30}$

Revival and other evangelistic meetings continued to be commonplace for the Mineral congregation through the 1920s. Those meetings hearkened back to the revival fires of the Second Great Awakening, whose mass gatherings became a mainstay for Baptists and Methodists in the first half of the nineteenth century. They helped spread the message of popular religion throughout the country, especially to lower and working class people, as well as to farmers, who may have found getting to town for weekly services difficult. The protracted meetings of the late nineteenth and early twentieth centuries were intended for the same purpose.

\footnotetext{
${ }^{27}$ “Constitution and By-Laws," 4.

28،"Statistics of the Eastern Association," Minutes of the Eastern Association, 1890, n.p.; 1900, n.p.; 1905, n.p.; 1910, n.p.; 1920, n.p. By 1925, church membership reached sixty-five.

29"Minutes," Mineral Baptist Church, 1886, 8; Tenth Census of the United States, 1880; Twelfth Census of the United States, 1900.

30“"Minutes," Mineral Baptist Church, 1887, 13; Twelfth Census of the United States, 1900.
} 
Umstot and his successor, the Reverend T.J. Riggs, held protracted meetings throughout their pastorates. In the 1910s, an evangelist named A. Bailey began holding meetings in his home. The General Association appointed him missionary to Grant and Hampshire Counties in 1909. They believed even this small portion of the Eastern Association was too large a field to be manned by just one person and earnestly desired to get more missionaries into that area. ${ }^{31}$ This never happened, and Bailey ministered to more than just the two counties assigned to him, helping add to the ranks of the Mineral Baptist Church. ${ }^{32}$

The composition of the church remained much the same during the church's first thirty years. Women outnumbered men nearly three to one. Most of the women did not work outside the home, and most of those who did were housekeepers for others. Generally, the men were divided among farmers, tradesmen such as carpenters, and railroad laborers. No managers or businessmen, such as coal operators or factory owners, appeared on the membership lists. While the lists were not complete, the data suggests a church comprised mostly of farmers, with working and lower-middle class wage earners constituting a sizable minority. All listed members were native-born whites, most of them originally from Virginia or West Virginia.

From the beginning, leadership positions were open to all men, regardless of secular social standing. The first "deaken" was an unemployed farmer worker. The church clerk was a land-owning farmer. The three delegates dispatched to help found the Eastern Association reflected a commitment to a spiritual equality that did not depend on secular relationships. One was a land-owning farmer who employed others to help work his land, one was a railroad

\footnotetext{
31"Executive Board Report," Minutes of the Baptist General Association of West Virginia (Parkersburg, WV: Sentinel Publishing, 1909), 21.

32،“Executive Board Report," 1918, 62
} 
yardmaster, and the other was a railroad laborer. ${ }^{33}$ The participation of the latter two suggests how men who in the secular world perhaps experienced an unequal relationship - as laborer to boss - landed on equal footing in the sacred realm. The church made no distinction between rich and poor. The small size of the church also meant there were only a few deacons over the thirty years of church life sketched here. In 1890, the church elected two more deacons - one a landing-owning farmer and one who rented. In 1907, another land owning farmer was selected as deacon. ${ }^{34}$

While it seemed that farmers, whether land-holding or not, controlled the diaconate, this could very well reflect the fact that they constituted the majority of the members. Aside from deacon and association delegate, there were other offices which also reveal a commitment to spiritual equality. The first two clerks were men, a farmer and a railroad laborer, but from 1895 through the early 1920s, women occupied the position exclusively. By the 1910s, women also began serving as church treasurers. Many Baptist churches at the time did not allow women to vote. Church records did not indicate whether women possessed the vote, but the fact that women were elected to the positions of clerks and treasurers suggests that women did have a voice in congregational decisions. Either way, women played a leadership role in the church, even if it was a role in some ways consistent with the contemporary Victorian notion of separate spheres for men and for women. ${ }^{35}$

Through the first years of the 20th century, delegations to the association consisted of men from all social classes and occupations. Because of the small size of the congregation,

\footnotetext{
33،"Minutes," Mineral Baptist Church, 1886, 11; 1889 18; Tenth Census of the United States, 1880; Twelfth Census of the United States, 1900.

34،"Minutes,” Mineral Baptist Church, 1890, 20; 1907, 54.

35“"Minutes,” Mineral Baptist Church 1895, 36; 1902, 45; 1912, 57; 1918, 63.
} 
many of the men represented the it several times. Although the church did not allow women to serve as deacons (or pastors) during this period, beginning in 1908 it chose women to serve as delegates to the association. This also points to women being allowed to vote in congregational meetings, but, again, this is only an inference, albeit a strong one. ${ }^{36}$ Acceptance of women as association delegates indicates something of a shift away from traditional understandings of female roles, even as it could have re-enforced basic conceptions of secular gender functions. Women, elected by the congregation, perhaps just by its male members, officially represented the group. From an organizational perspective, association delegates played an important role. They strengthened ties among churches and provided support to pastors. However, the nature of the Baptist association inherently limited the significance of female delegates. The association had no authority over the local congregations, and delegates exercised no spiritual authority, either over other the local congregation or in the association meeting.

In 1891, the church formed a Sunday School. The first Sunday School Superintendent was an elderly farmer. Not until 1918 is another mentioned, again a farmer. ${ }^{37}$ Although the records do not mention this position frequently, in all likelihood only men held it. Traditionally, Baptists did not believe women could teach or be in authority over men, even young men. Women could, however, teach girls and younger boys. Mineral Baptist probably had female Sunday School teachers, who served under the authority of the Superintendent.

True to Baptist teachings, no formal education was required to teach or preach, although one called to preach did have to be a man. Over the course of the first thirty years, the church licensed two men to preach. In 1891, the church granted an elderly farmer the privilege to

\footnotetext{
36“Minutes," Mineral Baptist Church 1908, 55.

37،"Minutes,” Mineral Baptist Church, 1891, 26; 1918, 63.
} 
"exercise the gifts when in prayer meetings and in exertation [sic] from the word as opportunity might present themselves [sic]." Three years later, the group licensed young farmer to preach. ${ }^{38}$ Thus, the Mineral Baptist Church showed limited diversity of membership but various affirmations of the egalitarian theology and polity of Baptists. Farmers constituted a majority of the congregation and so held many of the highest elected positions in the church. While the diaconate was closed to women, men of all social standings could occupy the office. All other positions (e.g. Sunday School Superintendent, church clerk, treasurer) eventually opened to both men and women, and people from all ranks of secular society participated in these aspects of church life.

West Virginia Baptists certainly benefited from the work of Virginia missionaries in Mineral County, but West Virginia ties with the ABHMS worked to its advantage in the mountain counties just to the south and west, including Grant, Tucker, Randolph, and Pocahontas. The work in Grant Count followed the pattern set by Umstot in Mineral. The new railroad towns in the northwest corner of the county were not the center of evangelic efforts; rather, missionaries concentrated on two other sections of the county: the more populous southern part of the county near Petersburg, the county seat, and the north-central part, closer to the older towns. In the three remaining counties studied here, the missionaries closely followed the railroad as it drove deep

\footnotetext{
38،"Minutes," 1891, 24;1894, 34. During the late nineteenth and early twentieth century, many Baptists followed a traditional literal interpretation of I Timothy 3:1-13 and other passages and permitted only men to serve as pastors and deacons. Many churches also prohibited them from speaking or voting in business meetings and teaching men or teenage boys. Despite the widespread prohibition in the Northern Baptist Convention (later American Baptist Churches, USA) on female pastors and deacons which extended well into the twentieth century, the decision was still left to the local congregations and associations, and was not expressly forbidden at the national convention level. See Leonard, Baptists in America and Baptist Ways; McBeth, Women in Baptist Life (Nashville: Broadman Press, 1979); and Fisher Humphreys, The Way We Were (Macon, GA: Smith \& Helwys, 2002). Many Baptist churches had an office of deaconess for women. However, most churches with this office did not ordain these women. The deaconess was an assistant to the deacon. This practice was most common in America and England in the eighteenth and early nineteenth centuries. After the Civil War, the deaconess position, both ordained and nonordained, steadily declined in the United States. For more on deaconess in Baptist life, see Charles W. Deweese, Women Deacons and Deaconesses: 400 Years of Baptist Service (Mercer, GA: Macon University Press, 2005).
} 
into the mountains. New churches in these counties were established in communities immediately along the route, often in newly-formed towns.

The presence of Baptist General Association missionaries in the mountain counties preceded official cooperation with the American Baptist Home Mission Society and came before the WVC\&P extended south into Randolph County and the Coal and Iron Railway climbed into Pocahontas County. In 1883, the BGA appointed W.H. Davis as missionary to Grant County. There was as yet no church in the county, but the mood was optimistic. Within the year, Rev. Davis planted one church and purchased a lot for a building. "I feel that we are on the eve of a revival," he reported to the General Association. ${ }^{39}$ This one church was North Mill Creek Baptist Church, located in the southern part of the county near Petersburg, not along or near the WVC\&P. ${ }^{40}$

It was not until 1890 that missionaries planted a Baptist church, Davis Baptist Church, closer to the new railroad. It was not directly along the track, though, but in Maysville, the old county seat, in the center of the county. Rev. Umstot founded the church along with Rev. Davis, the namesake of the church. The Rev. Macando was called as the first pastor, and the body met in school houses and outdoors before an edifice was constructed. ${ }^{41}$ In 1906, a portion of the congregation from Kline’s Gap and Jordan Run formed Harmony Baptist Church, “a regular organized missionary Baptist church according to the teaching of the New Testament." These

\footnotetext{
39،"Report of the Executive Board to the Baptist General Association of West Virginia," Minutes of the Nineteenth Annual Session of the Baptist General Association of West Virginia, 1883, 16, 17.

40، A Brief History of the North Mill Creek Baptist Church,” The Dorcas/Maysville Parish, (Maysville, WV: SelfPublished Church History, 1967), n.p.

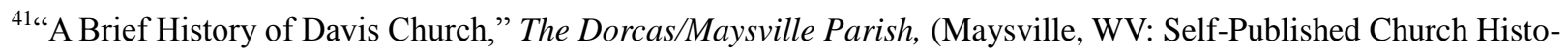
ry, 1967), n.p.
} 
believers desired their own church to better serve the needs of their area and split amicably from the mother church. ${ }^{42}$

None of these congregations grew very large. In 1900, the first year that Davis Baptist appeared in the minutes of the Eastern Association, it claimed forty-two members. This number peaked five years later at ninety-seven before plateauing around fifty for the next two decades. While the numbers of its founding members are unknown, Harmony had thirty-one congregants in 1910. Over the next decade, that number increased steadily, reaching sixty-three in $1920 .^{43}$ A number of other similarities existed among these Baptist churches. Native-born whites, most of whom were farmers, made up the overwhelming majority in each congregation. Some members of the industrial working class joined, particularly toward the end of the Progressive Era. Records of the churches suggest that no one in an upper-middle class or upper class occupation belonged during this time. Men, but only men, of all occupations served as deacons and trustees. By the mid-1910s, women from Harmony began serving as church clerks and delegates to the association. ${ }^{44}$

\footnotetext{
42،"Minutes," Harmony Baptist Church, 1906; 1907, 13-15, 23-28, 38. The term "missionary Baptist church" does not indicate the denomination by that name examined in Clifford Grammich's Local Baptists, Local Politics. In the context of the nineteenth century, the term "missionary" was used adjectivally to refer to Baptists who supported missionary activity, as opposed to the anti-mission Baptists. A number of Baptist churches in the Allegheny highlands applied this term to themselves. All worshipped well within the confines of the Baptist mainstream; none of them were Old School Baptists.

Despite forming a single new church, the two segments of Harmony continued to worship separately. They were also served by the same pastor, deacons, clerks, and trustees. While this church served the people of Jordan Run, there was another church there. Founded in 1903, it was a union church, serving both Baptists and Brethren. No records remain and it is not mentioned in the records of the other churches, just in the history of the Dorcas/Maysville Parish. In 1924, thirteen members of Harmony Baptist from Jordan Run withdrew from Harmony "to start a church of their own at Jordan Run." The relationship between the union church and the later Jordan Run church, or any of the Baptist churches in that part of Grant County, is unclear. The union church never appeared in the records of the Eastern Association. See "Minutes," Harmony Baptist Church, 1915, 59, 60; 1924, 79.

43،"Statistics of the Eastern Association,” Minutes of the Eastern Association, 1900, n.p.; 1905, n.p.; 1910, n.p.; 1915, n.p.; 1920, n.p.; 1925, n.p.

44“"Church Covenant," Davis Baptist Church, 1895; "Minutes," Davis Baptist Church, s.n, n.p.; "Membership Roll," Harmony Baptist Church, 1906, 18, 19; 1924, 81, 82; "Minutes," Harmony Baptist Church, 1906-1924, 18-82;
} 
The fact that women in Harmony Baptist served as clerks and association delegates is especially remarkable considering the congregation's use of James M. Pendleton's Church Manual. First published in 1867 by the American Baptist Publication Society, the manual contained a short, twenty-article statement of faith similar to the New Hampshire Confession. Pendleton was, however, a leader of the reactionary Landmark movement, which was particularly strong in the South. Landmarkers held that Baptists constituted the only true church and that Jesus himself was a Baptist. They also took extreme views on local church autonomy. Pendleton argued that deacons should be involved in the business affairs of the church, and thus also be clerks, treasurers, and trustees, which would make it impossible for women to be deacons. The fact they were at Harmony, a church clearly aware of Pendleton's views, shows that the congregation was truly committed to local church autonomy and egalitarianism. It charted its own course and made decisions for itelf, while staying within the Baptist tradition of reserving the biblical offices of pastor and deacon for men. ${ }^{45}$

As Rev. Davis started his work in Grant County, M.P.H. Potts labored in Randolph and Pocahontas counties, which the General Association grouped together as one mission field in 1881. Potts alone served them both - two of the largest counties in the state. His reports contained almost no detail. He told the Executive Board of the BGA that he remained encouraged in spite of the enormity of the task before him. ${ }^{46}$ The 1880 minutes of the Union Association showed a church existed in Valley Head, in southern Randolph County. Records do

Twelfth Census of the United States, 1900; Thirteenth Census of the United States, 1910; Fourteenth Census of the United States, 1920.

\footnotetext{
45"Minutes," Harmony Baptist Church, 1906, 13. The Davis church also adopted the confession found in Pendleton's manual. See also Deweese, 72.

46،"Report of the Executive Board to the Baptist General Association of West Virginia," Minutes of the Nineteenth Annual Session of the Baptist General Association of West Virginia, 1883, 17.
} 
not state that Potts founded the church, although he almost certainly did, preaching there until 1887, when the church disappeared from association records. At no time did the congregation number more than seven. ${ }^{47}$

A brief column in the September 1888 issue of The Baptist Home Mission Monthly about the strength of Baptists in West Virginia indicated there was one church each in Randolph and Pocahontas counties, as well as one in Tucker. ${ }^{48}$ However, the article gives no detail about their origins or locations. The column also does not specifically credit the churches to Potts' work or any other mission work; rather, it implicitly linked the congregations with other Baptist churches affiliated with the West Virginia General Association. That edition of the home mission publication is the only reference to these churches; General Association and local association records make no mention of them.

The first permanent church established in the area in which Potts labored, and directly along the mainline of the WVC\&P, was the First Baptist Church of Elkins, established in direct response to the railroad and the growth and development it promised. In the winter of 1889 , three Baptist preachers, including Superintendent Powell, preached at the Presbyterian Church in the new town of Elkins. The locals did not respond and Powell made no further effort to start a Baptist church there. The next year, noting the rapid growth of the town after the arrival of the railroad, Powell returned. In November he preached at the school house, inviting those there saved to join the Baptist church he was forming. Six people came forward to unite with that new church, and on November, 16, 1890, they were baptized in the Tygart River. According to church records, a large crowd gathered and Powell used the occasion to teach on baptism by

\footnotetext{
47"Financial and Statistical Tables," Proceedings of the Union Association, 1880, n.p.; "Financial and Statistical Tables," 1887, n.p.

48،News and Notes," The Baptist Home Mission Monthly 10 (Sept. 1888), 243, 244.
} 
immersion, arguing that it was "the Apostolic mode of baptism: the way taught and practiced by Jesus himself." "Never before had the ordinance been administered here by a minister of our denomination," Powell wrote in the introductory minutes. The new group declared itself "regular, straight forward, close communion Baptists."

Powell served as pastor of the Elkins congregation, which met in the school house for the next few months. He organized a Sunday School, which quickly grew to eighty-five participants. By the end of 1890, the church had twenty members. ${ }^{50}$ In February 1891, the people called the Reverend Amos Robinson of Rhode Island to be their minister. Robinson accepted and started on April 1 of that year. Like Mineral Baptist, the Elkins church began as independent, but after the arrival of the new pastor, it requested membership in the Union Association and was therein received. The congregation initially met in the school house and in the Presbyterian Church. Thanks to a donation of land from Henry Gassaway Davis, the church erected a meeting house near downtown Elkins in November of 1891. Stephen B. Elkins attended the inaugural service. ${ }^{51}$ Not only did Robinson occupy the pulpit of the Elkins church, but the General Association also appointed him missionary to Randolph and Tucker counties. Powell's early successes did not translate into continued growth, and Robinson quickly recognized that his labor would be difficult. The region in general was not amenable to Baptists, and he identified Elkins in particular as "a strong paedo-Baptist community.",52

\footnotetext{
49،"Introductory Minutes," First Baptist Church of Elkins, 1890, n.p.

50،"Church Edifice Department,” The Baptist Home Mission Monthly 15 (Nov. 1893), 364.

51“"Minutes,” First Baptist Church of Elkins, 1891, n.p.; Deed Book V, Page 35, 1891.

${ }^{52}$ Amos Robinson, "Report from Elkins," The Baptist Home Mission Monthly 24 (June 1902), 177. "Paedo-baptism" means infant or child baptism, after the Greek word for child.
} 
Robinson did not elaborate on this anti-Baptist sentiment. The presence of Primitive Baptists in the county who abstained from mission work, revivals, and Sunday Schools could, in part, account for it. The lack of community outreach among Primitive Baptists perhaps led valley residents to believe that all Baptists were similarly unconcerned. On the other hand, Methodists and Presbyterians, both of whom practiced infant baptism, maintained a much greater public presence.

The two Primitive congregations in Randolph County constituted the only Old School Baptists in the mid-Allegheny region. Until the 1880s, they made up the entire Baptist presence in the five counties studied here. Both churches originated from a single missionary Baptist church in the early nineteenth century and fellowshipped with other churches in the Union Association, the local Baptist association that served several counties in what became northcentral West Virginia. ${ }^{53}$

Immigration formed another factor in this anti-Baptist attitude. As the Superintendent of Missions noted in 1904, most of the people moving into this area, whether native or foreignborn, were, if Christian, paedo-Baptists, thus giving other denominations an advantage. ${ }^{54}$ Whatever the reason, church membership records seem to verify this observation. By 1900 , the Elkins church claimed just forty-two members. Rev. Potts came to help Robinson in the church,

\footnotetext{
${ }^{53}$ Daisy Ferguson Martin, Montrose Community History (Elkins, WV: Published for the Montrose Historical Society,1991), 14. The Valley Baptist Church, the original Primitive Baptist congregation in Randolph County, objected to missionary endeavors and separated from the Union Association in 1826 over that issue. Few records exist for either the Valley church or its sister congregation, the Leading Creek Old Side Baptist Church. However, by the 1890s, membership in each church stood at less than fifty. While these low figures could be due to missionary Baptist encroachment, Primitive Baptist practice in general did not encourage membership growth. Their lack of ministry within the surrounding community could also help explain the local population's initial animosity to Baptists. Perhaps locals associated the new missionary Baptists with their anti-mission counterparts and thus became weary of any Baptist message, regardless of the source. See "Business," Minutes of the Union Baptist Association, 1826, 4; Maxwell, A History of Randolph County, West Virginia, 313.

54،Kanawha District Report," Seventieth Annual Report of the American Baptist Home Mission Society (New York: ABMHS, 1904), 305-306.
} 
allowing him to concentrate on mission work in the two counties. These early results did not discourage Robinson, his successors, or the church. Five years later, with H.F. Loomis as pastor, the congregation numbered 120, a nearly 200 percent increase over the period. Growth slowed over the next five years, with church membership increasing to 148 by 1910 when G.E. Barlett served as pastor.

By 1915 T.H. Tiffany occupied the pulpit, and the congregation grew to 221 . The next five years witnessed the most significant jump. With yet another man, Joe W. English, serving as pastor, the First Baptist Church of Elkins boasted 488 congregants, making it the third-largest Protestant church in Randolph County and the largest Baptist church along the mainline of the West Virginia Central and Pittsburg. ${ }^{55}$

Records at local and associational levels give few clues as to how Baptists curried favor with local residents. The greatest period of growth occurred after the turn of the century, yet the commentary about progress in those years is almost non-existent. In 1907, Amos Robinson, who began work in 1902 as a full-time ABMHS missionary and American Baptist Publication Society colporteur to Randolph and Tucker counties, simply noted that the "prevailing anti-Baptist sentiment [had been] overcome and Baptist sentiment created." ${ }^{\circ 6}$ During his time at First Baptist Church of Elkins, as he laid the foundation for a future harvest, Robinson, like other Baptist and Methodist preachers in the state, relied on the revival.

In the winter of 1892, he held a "protracted meeting" for five weeks in Elkins. Despite the weather and the prevalence of a sickness he called the "grippe," (which was a term used for influenza) Robinson was pleased by the attendance, which averaged more than sixty per night.

\footnotetext{
55،Statistical Church Report," Minutes of the Union Association, 1900, 12; 1905, 33; 1915, 29; $1920,40$.

56،West Virginia Mission Report,” Minutes of the Baptist General Association of West Virginia, $1907,18$.
} 
The "grippe" seemed particularly rampant among church members, as there were several nights no one in the audience was a believer. Yet this did not deter Robinson, who took encouragement from the high numbers of unbelievers at the meetings. ${ }^{57}$ Two years later another revival began in December and lasted seven weeks. A Southern Methodist evangelist from Parkersburg initiated the revival, and "the town and the surrounding country was stirred and all denominations were blest by it [sic]. ${ }^{, 58}$

A letter to the Union Association described Baptist participation in the protracted meeting and its results. Rev. Potts returned to the county, and along with a young ministerial candidate, preached and taught the distinctive doctrines of Baptists. Fifteen people joined the church, many of them young, and they organized a weekly young peoples' meeting in town. Baptists also established a new preaching station and Sunday School three miles outside of town. ${ }^{59}$ However, the optimism soon faded. As quickly as they ignited, the fires of revival extinguished. Later in 1895 , the church lamented that the county now suffered from "spiritual coldness and indifference." The congregation, however, still appeared healthy. It continued holding to the "good old doctrines of the Bible." ${ }^{60}$ Rev. Robinson held more protracted meetings in 1896. His duties as missionary, however, required that he go into the mountains. Another pastor, perhaps Rev. Potts, assumed charge of one of the revivals during this time. Just as before, sickness plagued the church, hindering attendance not only at the revival but also at regular Sunday services. ${ }^{61}$

\footnotetext{
${ }^{57}$ Amos Robinson, “A Needy Field in West Virginia,” The Baptist Home Mission Monthly 14 (June 1892), 184, 185.

58،"Letter to the Union Association,” First Baptist Church of Elkins, 1894, n.p.

59،"Letter to the Union Association,” First Baptist Church of Elkins, 1894, n.p.

60“"Minutes," First Baptist Church of Elkins, 1895, n.p.

${ }^{61}$ Amos Robinson, “A Letter from Elkins,” The Baptist Home Mission Monthly 18 (Aug. 1896), 286.
} 
With the exception of the 1893-1894 revival, the records are unclear about how successful these revivals were. Since church membership at the turn of the century stood at only forty-two, just double what it had been a decade earlier when the church was founded, it seems that the Baptist message fell largely on deaf ears. Robinson's successors are credited with building the First Baptist Church of Elkins into a large, healthy, prosperous congregation. However, perhaps the protracted meetings in the early days softened the ground and fertilized the soil for later harvests.

The Elkins church prospered in the early twentieth century, and revivals continued as a regular part of Baptist life in Randolph County. In 1911, evangelistic services began in midJanuary and continued into March. Much like the revivals of the Second Great Awakening, this one seemed to be the product of planned spontaneity. The meetings were scheduled to run for at least a week, but they proceeded much better than expected. By February, an announcement appeared in the newspaper reading "The meeting will continue until further notice." ${ }^{62}$ It does not seem that any official notice of cessation was ever issued, but by March the revival fires died down. The duration of the revival suggests great success for the Baptists, although records give no indication of the number of converts won at these gatherings.

A revival in 1917, conducted with the help of a group called the Blue Mountain Evangelist Forces, yielded 100 conversions. ${ }^{63}$ While the records do not specify that all those saved joined the Baptist church, this awakening no doubt significantly increased membership. Thus, the revival tradition in general helps account for the growth and success of Baptists in

\footnotetext{
62،"Baptist Meeting,” Elkins Inter-Mountain, Jan. 14, 1911, Jan. 21, 1911, Feb. 4, 1911.

63،Minutes," First Baptist Church of Elkins, 1917, n.p.
} 
Elkins. Those two protracted meetings in particular do much to explain the significant growth of the Elkins church after 1910.

Of the Baptist churches covered here, the records for the Elkins congregations are most complete. While Elkins was larger and more prosperous than the county seats of other counties along the WVC\&P, the Baptist church there had a similar social and racial/ethnic composition to other Baptist churches in the Alleghenies. The congregation remained predominantly working and lower-middle class through 1920. While the church lacked social diversity, the egalitarian nature of Baptist polity and theology is evident. Most of the men were farmers, but not all owned land. The first deacon was a butcher who lived with his father-in-law. The second clerk, who took over the position shortly after the church opened, due to the drowning of the first clerk in the Tygart River, was a machinist. Few, if any, land-owning farmers joined the church before 1900. Most of the men who joined were laborers, on farms, in mills, or in mines. ${ }^{64}$ Rev. Robinson noted the poor economic state of the congregation. The depression of the 1890s hit the group hard. Work was scarce and wages were low. Even those from the middling ranks were not immune. "When I asked one of our best brethren in Elkins what he could do for our Home Mission Society, he told me his financial condition. I could hardly refrain from tears," wrote Robinson in a letter The Home Mission Monthly, a national Baptist mission publication. ${ }^{65}$ Despite the low economic status of its early members, the church managed to become financially independent by 1900. The American Baptist Home Mission Society dropped them from its support roll that year. ${ }^{66}$

\footnotetext{
64“"Official Register of Deacons,” First Baptist Church of Elkins, n.p.; “Clerks,” n.p.; "Chronological Register of Members," n.p.; Twelfth Census of the United States, 1900.

${ }^{65}$ Robinson, "What a Missionary Thinks," The Baptist Home Mission Monthly 17 (Sept., 1895), 134.

66،"Minutes,” First Baptist Church of Elkins, 1900, n.p.
} 
Socially, the church became more diverse during the first two decades after 1900, although few upper-class residents from the industrial or commercial sectors of the economy joined the church. Many of the new members continued to be wage-earning laborers, tradesmen, and clerks. Farmers, many of whom owned their land, also joined the church in greater numbers. Nevertheless, leadership opportunities remained open to persons of all social standing. From 1900 to1920, deacons came from all ranks of society, except from the capitalist elite. ${ }^{67}$ Like other Baptist churches in the region, First Baptist of Elkins permitted only men to be deacons or Sunday School Superintendent, but unlike the other churches surveyed here, the position of church clerk was also occupied only by men. Men from all social ranks occupied these positions, but whether the by-laws prohibited women from being clerks is unclear. Elkins records do not list association delegates, so women's opportunities in the areas of church life remain unknown. The one job that was certainly available to them was treasurer. The first five treasures were all women, but after the turn of the century men held the job exclusively. ${ }^{68}$

While men of all secular occupations had the opportunity to serve in various leadership capacities, it appears that women enjoyed fewer opportunities in the Elkins church than in other Baptist churches throughout the Alleghenies. To be sure, the records are largely silent. But the fact that women were not church clerks suggests the Elkins congregation was at least somewhat more conservative than its counterparts in other counties. The fact that women ceased to occupy the post of treasurer after 1900 could also reflect a reactionary trend among the congregation. In any event, the First Baptist Church of Elkins exhibits many of the egalitarian characteristics

\footnotetext{
67"Deacons," n.p.; Twelfth Census of the United States, 1900; Thirteenth Census of the United States, 1910; Fourteenth Census of the United States, 1920.

${ }^{68}$ “Official Register of Sunday School Superintendents," First Baptist Church of Elkins, n.p.; "Official Register of Clerks," n.p.; "Official Register of Treasurers," n.p.; Twelfth Census of the United States, 1900; Thirteenth Census of the United States, 1910; Fourteenth Census of the United States, 1920.
} 
typical of Baptists in West Virginia and across America during the Gilded Age and Progressive

Era while at the same time displaying a strong commitment to historic Baptist understandings of male authority within the church. Whereas women in other churches in the area enjoyed substantial leadership opportunities in the business and organizational aspects of the church, even as men retained control of purely spiritual affairs, women in the Elkins church enjoyed far fewer privileges, and by the turn of the century perhaps none.

Baptist missionaries in Randolph and Tucker counties used the railroad to their advantage. However, they did not necessarily follow the track as it was laid. Amos Robinson's field included both Randolph and Tucker counties, but Baptists began their work in Randolph first, and then moved back north to Tucker County. Robinson founded three churches in new towns in that county in $1892 .^{69}$ Of the three the First Baptist Church of Parsons enjoyed the most success. There were eleven founding members, and W.F. Bennett served as the first pastor. A Reverend Raasch took over the church in 1896 and remained for two years. By 1900, with Michael Angelo Kelley in the pulpit, the church had just nine members. However, with the help of the Home Mission Society, the church purchased land from Lemuel Parsons for the construction of a building. Kelley left after just one year, but over the next four years the church experienced solid growth, reaching forty-nine congregants in 1905 under C.H. Pack, who also

\footnotetext{
${ }^{69}$ In addition to Parsons, the other two new churches were Hulings (Hambleton) and Davis. The Hulings congregation formed after an eighteen-day revival. While the town was remote, the missionary connected the new body of believers with the other Northern Baptists by providing them with literature and tracks from the American Baptist Publication Society. Under the guidance of W.F. Raasch of Kansas, who moved to the mountains in 1896 to help in Tucker County, the congregation erected a building, the first Baptist building in the county. Both he and Robinson also focused on nearby Hendricks, but with limited success. A congregation appeared there in 1897, but was never viable. In 1897, Hulings was read into the Union Association. Three years later, the small church had a pastor and eighteen members. The congregation reached a maximum of sixty-eight in 1910. Five years later, membership had declined to forty-five, and shortly thereafter closed. Besides the reports contained in the Union Association, no other records remain. The Davis body struggled to remain viable. It was read into the Union Association in 1897, but disbanded shortly after that. See "A Needy Field in West Virginia," 185; "Executive Board Report," Minutes of the Baptist General Association of West Virginia, 1896, 30; 1897, 32; 1898, 39; 1900, 51; Report on Newly Constituted Churches," Minutes of the Union Association, 1897, 7; "Statistical Church Report," Minutes of the Union Association, 1900, n.p.; 1910, n.p.; 1915, n.p.; and "Report on Newly Constituted Churches," 1897, 7.
} 
served Hambleton. That number nearly doubled over the next five years to ninety-seven. Between 1910 and 1921, by which time it was the only Baptist church in Tucker County, membership hovered in the low to mid-nineties, and at least three pastors occupied the pulpit. ${ }^{70}$

Beyond the statistical information sent to the association, records are almost non-existent for the Parsons church. Some missionary correspondence helps give a partial picture of the growth, development, and social composition of the congregation. The story is similar to that of the church in Elkins, but also indicates a church very active in Parsons and other towns in Tucker County. The Sunday School formed by Rev. Pack also served as a community outreach. From the Sunday School he formed a boys' club. To be a member, a boy had to attend Sunday School and "refrain from smoking cigarettes." The club soon grew to fifty boys, aged 10 to 16 . Pack organized these into four baseball teams and devoted himself to managing them, umpiring their games, and traveling with them to play teams from neighboring towns. ${ }^{71}$ Until Pack's ministry, the Parsons church "was without love or favor among the people." Association minutes credit him with remedying the anti-Baptist attitudes in the county. Along with Rev. Robinson, he reorganized the church in Davis. ${ }^{72}$

Most of the other records that survive are from the mid-twenties, just outside the period covered here, but they suggest a good picture of the social composition of the church between its founding and 1920. Most of the members were farmers, tradesmen, or laborers. There was at least one lumber merchant in the congregation, but the overwhelming majority of the members probably did not come from the new upper class of businessmen and capitalists. Most of the

\footnotetext{
70“"Statistical Church Report," Minutes of the Union Association, 1893, n.p.; 1900, n.p.; 1905, n.p.; 1910, n.p.; 1921, n.p.; Homer Floyd Fansler, History of Tucker County (Parsons, WV: McClain Printing Company, 1962), 635.

${ }^{71}$ C.H. Pack, "Parsons,” The Baptist Home Mission Monthly 31 (April 1909), 180-181.

72،"Executive Board Report," Minutes of the Baptist General Association of West Virginia (Parkersburg, WV: Sentinel Publishing, 1904), 23.
} 
wealthier members were probably farmers but, unlike the Mineral Church, existing rolls suggest that farmers constituted a minority of the Parsons church, albeit a substantial one. The majority of the members held wage earning jobs in mills and factories, although few seemed to be coal miners. Men in trades and wage earning lower clerical positions comprised another large minority of the group. ${ }^{73}$

During his time as pastor and missionary, Amos Robinson organized or helped organize five other Baptist churches in his territory, in addition to the three in Tucker County and one in Elkins. Three were white congregations and two were black. ${ }^{74}$ Overall, Robinson established nine churches during his tenure as pastor and missionary in the region. Although he left the pulpit of First Baptist of Elkins in 1902, he did not leave the mountains. As a colporteur

\footnotetext{
${ }^{73}$ Fansler, 634; Twelfth Census of the United States, 1900; "Minutes," First Baptist Church of Parsons, 1904, n.p.; "List of Members," 1926, n.p. Unlike the churches in Mineral and Grant counties, a noticeable number of Parsons parishioners moved to West Virginia from Pennsylvania. Interestingly, it appears these particular in-migrants did not take mining, milling, or logging jobs, but found employment in retail stores or with local governments. Loggers, miners, and mill workers in the church were born in West Virginia.

${ }^{74}$ Robinson, "Letter from Elkins," 177. One of the white churches was in Montrose, a small farming community in Randolph County along the WVC\&P between Elkins and Parsons. The Union Association received it into fellowship in 1897. Organizing a missionary Baptist church here made sense because of the presence of an antimission Primitive Baptist church in the community. In fact, Robinson made some progress in overcoming antimission attitudes in that town. A.W. Murphy, the son of the local Primitive Baptist minister, helped preach at the missionary Baptist church and served as the church clerk. By 1900 it had a pastor, but just twelve members. Five years later, the numbers were the same, and by 1910 the church ceased to appear in the minutes of the Union Association. It seems anti-mission sentiment there was just too great to overcome. The other white church was in Faulkner, a tiny town on the Shaver's Fork of the Cheat along the route of the Coal and Iron Railroad from Elkins to Durbin. It was frequently neglected and never appeared in association records. State mission reports also indicate some work in Huttonsville and Valley Head, but only briefly. Baptists established a mission in Valley Head in 1891, and four years later it had twenty-two members, but no building. After that, however, it faded from the records. By 1900, the whole of southern Randolph County seems to have been almost completely neglected. See Daisy Martin Ferguson, "Montrose Community History," Published by the Montrose Community Historical Committee, 1991, 14; "Statistical Church Report," 1900, n.p.; "Report on Newly Constituted Churches," Minutes of the Union Association, 1897, 7; "Statistical Church Report," 1900, n.p.; 1905, n.p.; "State Mission Report," Minutes of the Baptist General Association of West Virginia, 1900, 37; "Letter from Elkins," 177; Letter from Elkins," 177; "Statistical Church Report," Minutes of the Union Association, 1891, n.p.; 1895, n.p.

Robinson notes that there were seven churches in the two counties in 1902 - five white and two black. One of these, the Shiloh Baptist Church (also called Second Baptist Church), was located in Elkins and founded by working class blacks in 1897. However, the name and location of the second black Baptist church remain a mystery. Black church records in West Virginia from this period are even more sketchy than records from white churches. Robinson's column in the home mission monthly is the only place any mention of another black church appears.
} 
missionary he continued to conduct revivals, plant churches, and support ministers in the region. $^{75}$

As the Randolph County mission plateaued over the course of the first decade of the twentieth century, efforts in Tucker County seemed to flourish. L.J. Pack joined his brother in Parsons and by 1906 had taken responsibility for the churches and outstations along the railroad in the northeastern portion of the county. In 1907 he extended the field, moving north along the track into Grant County and establishing a church at Gormania. Three years later, as the church in Parsons continued to grow slowly, Pack ministered to a total of seven churches and outstations in northeastern Tucker County and western Grant County. But success was fleeting. By 1912, the General Association lamented that Pack labored in "an unproductive field." Baptist gains along the WVC\&P in Tucker and Grant quickly evaporated. Pack and others continued the work, but none of the new churches or outstations remained viable. None joined associations, and no local records survive. ${ }^{76}$

Thus, of the various Baptist churches established in the Randolph/Tucker County field over the course of the Gilded Age and Progressive Era, only three remained consistently viable over the period. By 1920 the Baptist presence in the two counties dwindled to just three churches - two churches in Elkins, one white, one black, and the church in Parsons. Pocahontas County, which had been a part of Rev. Potts' mission field in the early 1880s, remained a difficult field which apparently was not manned consistently in the last fifteen years of the nineteenth century. Rev. H.P. Hardway came to Pocahontas in 1896, focusing on the small town of Lobelia in the

\footnotetext{
${ }^{75}$ The term "colporteur" refers to a person whose worked consisted exclusively of distributing Bibles, religious literature, and hymn books. Colporteurs cooperated with local religious leaders to meet the needs of congregations. The railroad revolutionized this ministry, allowing for more rapid transportation of larger quantities of material. Many colporteurs had specialized railcars complete with mini-libraries and keyboards.

76،“Executive Board Report," Minutes of the Baptist General Association of West Virginia (Parkersburg, WV: Sentinel Publishing, 1907), 6; 1910, 30; 1912, 24.
} 
southern-most part of the county, along the border with Greenbrier County. By 1900, S.G.

Callison was in the county, but the work lagged. Initially he simply went from house to house, preaching when he could. He labored hard to overcome great prejudice toward and ignorance about Baptists and eventually was welcomed in many pulpits throughout the county. While no church was formed, Callison reported several desired to be baptized, and others wanted to join a Baptist church. The Greenbrier division of the C\&O Railroad, which joined H.G. Davis's Coal and Iron Railway near Durbin, increased the importance of the Pocahontas field. At least one more missionary was required. ${ }^{77}$

The railroad revolutionized life in Pocahontas County. It brought more people and more jobs, but it did not bring more Baptists. For reasons that are unclear, Baptists were unable to take advantage of the railroad's advance through Pocahontas County the way they had in Randolph and Tucker Counties, and had at least tried to do in Mineral and Grant Counties. In 1906, Rev. Callison left Pocahontas for Nicholas County, forcing Rev. Robinson to expand his work into Pocahontas County. When Callison returned in 1908, he seemed to pick up where he left off. Thomas Woodridge came to help him in this "intense anti-mission, anti-Baptistic county." This second missionary labored in the southern part of the county, around Lobelia, and in parts of Bath and Augusta counties in Virginia. By 1910 they had organized a total of six churches across Pocahontas County. Two of them were along the railroad - one at Durbin with fourteen members and one at Marlinton, the county seat, with thirty-four members. ${ }^{78}$

\footnotetext{
77"State Mission Report," Minutes of the Baptist General Association of West Virginia, 1900, 37; "Executive Board Report," 1903, 23; Truett Rogers, West Virginia Baptist History: The Convention Years, 1865-1965 (Terra Alta, WV: Headline Books, 1994), 64, 65.

78،"State Mission Report," Minutes of the Baptist General Association of West Virginia, 1908, 43; "Executive Board Report," 1910, 29, 31; Rogers, 66, 68.
} 
The optimism of Callison's report was apparently short lived. After 1910, Pocahontas County completely disappeared from General Association records. Of the six churches reported, only one, that in Lobelia, ever showed up in any local association records. While the Lobelia church was founded in 1905, its first appearance in association records was not until 1914. In that year it reported forty-nine members to the Greenbrier Association. The next year the body had fifty members and was contributing to state mission work. The association gave no report for 1916, and, by 1917, Lobelia was gone from association records. No records for any local congregation remain. $^{79}$

\section{Mainline Theology for Mountain Baptists}

While some membership records remain for the white and black Elkins churches and the Parsons church, only those of the First Baptist Church of Elkins are detailed enough to provide insight into the specific theological beliefs of that body. The first letter to the Union Association stated that the First Baptist Church of Elkins adopted the New Hampshire Confession of Faith. Drafted in 1833 at the request of the New Hampshire Baptist State Convention, the New Hampshire Confession attempted to articulate a mediating position between Calvinism and Arminianism. The dominant belief among eighteenth century and early nineteenth century Baptists in both England and America was a soteriology (or doctrine of salvation) that emphasized God's sovereignty and particular election. God had chosen a certain number of people to be saved and go to heaven, a doctrine known as particular redemption. The rest remain unregenerate and spend eternity in hell. An individual could do nothing to earn, choose, desire, or prepare in any way for salvation.

\footnotetext{
79،"Greenbrier Association,” Minutes of the Baptist General Association of West Virginia , 1914; n.p.; 1915, n.p.; 1917, n.p.
} 
These positions emerged from the earlier Philadelphia Confession of Faith. In 1742, the Philadelphia Baptist Association adopted a slightly modified version of the Second London Confession. The American version "remained the principle Calvinistic statement for most Baptists in all sections until the Second Great Awakening of the 1820s." ${ }^{\prime 80}$ At the same time, however, the traditional concepts of predestination, election, and free will came under attack from various directions, especially in the North. The New England Theology gradually began to soften Calvinism, making more room for free will. Free Will Baptists preached a more overt Arminianism: that Christ died for everyone, and salvation was denied only to those who specifically chose not to believe.

One response to these deviations was a strict Calvinistic reaction. The Black Rock Resolutions were the best example of this course. A group of Baptist ministers, styling themselves as "Old School," met at Black Rock, Maryland in 1832 and drafted a statement of theological and ecclesiastical principles. It upheld the Calvinist views of the Philadelphia Confession as "established 'baptistic' doctrines," particularly emphasizing the sovereignty of God. This core position not only enabled the Old School Baptists to defend particular redemption, it also acted as a hedge against so-called "human inventions" such as revival meetings, Sunday schools, and mission societies. "A1 "As the Old School Baptists saw it, there was no scriptural basis for such activities, which represented certain 'arrogant pretensions' that regeneration is produced by impressions made upon the natural mind by means of religious sentiments instilled into it,"” explains Baptist historian Bill Leonard. The Black Rock Resolutions

\footnotetext{
${ }^{80}$ William H. Brackney, A Genetic History of Baptist Thought (Macon: Mercer University Press, 2004), 33-35, 40.

${ }^{81}$ Brackney, 38, 39. For more on the early development of Primitive Baptists, see James R. Mathis, The Making of the Primitive Baptists: A Cultural and Intellectual History of the Antimission Movement, 1800-1840 (New York: Routledge, 2004).
} 
became an important part of an emerging movement of anti-mission Calvinistic Baptists in the mid-antebellum period that came to be called Primitive Baptists. ${ }^{82}$

The New Hampshire Confession represented a more popular, mainstream response to the specter of Arminianism. The confession sought to represent the views of all the Baptist churches in New Hampshire, not just the Calvinistic ones. While drafted by the state convention, true to the traditional idea of Baptist autonomy, the convention never officially adopted the statement. Nevertheless, it became widely accepted throughout New Hampshire and the rest of the country by both local churches and denominational organizations by mid-century and maintained its prominence well into the twentieth century. ${ }^{83}$

Regarding salvation, the document moved away from the Calvinist position found in the Philadelphia Confession. There is no mention of God choosing some for salvation while all others die in their sins. Rather, the article entitled "Of the Freedom of Salvation" indicates that salvation is made available to all who accept it "by a cordial, [penitent,] and obedient faith." All that prevents one from being saved is an individual's "own [inherent depravity and] and voluntary refusal to submit to the Lord Jesus Christ." ${ }^{84}$ Note that while more emphasis is laid on an individual's ability to choose salvation, there is still an understanding that fallen humanity is, as stated in the article "Of the Fall of Man," "by nature utterly void of that holiness required by the law of God, wholly given to the gratification of the world, of Satan, and of their own sinful

\footnotetext{
${ }^{82}$ Bill Leonard, Baptist Ways: A History (Valley Forge, PA: Judson Press, 2003), 182.

${ }^{83}$ Leonard, 190.

${ }^{84 ، " T h e ~ N e w ~ H a m p s h i r e ~ C o n f e s s i o n, " ~ i n ~ B a p t i s t ~ C o n f e s s i o n s ~ o f ~ F a i t h, ~ 2 n d ~ R e v i s e d ~ E d i t i o n, ~ e d . ~ W i l l i a m ~ J . ~ L u m p k i n ~}$ and Bill J. Leonard (Valley Forge, PA: Judson Press, 2011), 380. The original text of the confession does not survive. Words in brackets are additions made by J. Newton Brown, editorial secretary of the American Baptist Publication Society, in 1853. He reprinted the statement in The Baptist Church Manual, adding two entire articles along with key words and phrases in select existing articles. Thus, the 1853 text would have been the version adopted by the First Baptist Church of Elkins.
} 
passions." A person cannot do anything to earn salvation. In faith and repentance they "turn to God with unfeigned contrition, confession, and supplication for mercy." God will protect and preserve the salvation of true believers, ensuring that none fall away. ${ }^{85}$ Thus, a balance is struck between God's sovereignty and human free will.

Regarding Scripture, the confession states that "the Holy Bible was written by men divinely inspired, and is a perfect treasure of heavenly instruction; that it has God for its author, salvation for its end, and truth, without mixture of error, for its matter." ${ }^{86}$ Leonard notes that while the exact meaning of the phrase "truth, without mixture of error" has been intensely debated, the statement came to represent a popular understanding of biblical authority. ${ }^{87}$ Like other Baptist confessions, the New Hampshire Confession focuses on the local, visible church rather than the universal, invisible church. The visible church is composed of baptized believers who observe Christ's ordinances and follow His laws. Believers' baptism by immersion "is prerequisite to the privileges of a church relation; and to the Lord's Supper." 88

This was the statement of faith of the First Baptist Church of Elkins. That local church was new, not only organizationally but also organically. When it adopted the New Hampshire Confession, the institution itself was barely a year old. More importantly to Baptists, the church as a group of believers was young, having been formed of new converts, not those leaving an existing congregation. Adoption of the confession signified continuity with both established traditional Baptist positions, such as those on the church, and traditional Baptist debates, such as those on Calvinism and Arminianism.

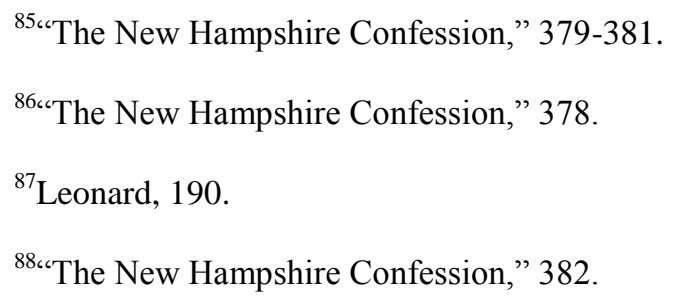


Furthermore, a comparison of the New Hampshire Confession, the confessions adopted by the other churches established along or near the mainline of the West Virginia Central and Pittsburgh, and the stated theological positions of the General Association reveals significant doctrinal similarities between West Virginia Baptists, both old and new, and between West Virginia Baptists and those in the rest of America, both North and South, during the late nineteenth and twentieth centuries. All of the churches, of course, adhered to the idea that baptism was the entry to the church and that only church members could be admitted to the Lord's Table. Those tenets were at the very core of Baptist identity.

The new Baptist churches in the mountains also shared the modified or evangelical Calvinism which had become common-place among many Baptists over the previous fifty years. Only the Mineral church used language reminiscent of the strict Calvinist orthodoxy of the eighteenth century, but, even that was carefully qualified. Historically, particular redemption meant that salvation was reserved for only those individuals God had specifically chosen to receive it. The concept was crucial to the Calvinist doctrine of predestination. The Baptists in Mineral County, however, used the term differently. To them, salvation was reserved for any who repented and believed in Christ.

The General Association articulated this middle ground. Once again, true to Baptist polity, the West Virginia state body did not adopt a confession of faith, leaving that task to the local churches where they believed the responsibility and duty rightfully belonged. However, they did briefly summarize the basic soteriological beliefs of all West Virginia Baptists. Writing at the Jubilee meeting in 1915, the Executive Board stated that "[w]e have held to the sovereignty of God; the direct access of all souls to God." ${ }^{\prime 89}$ The phrase "sovereignty of God" had always been at the very center of Calvinism. The great fear of Calvinists such as Old School ${ }^{89}$ Hank, et al, 74. 
Baptists was that any allowance of human free will in salvation would undermine God's purposes and will. If people were able in any way to choose to be saved, then God might not be completely in control. On the other hand, if people had no choice in the matter, it was then entirely up to God. Some were elect and some were not. However, this notion seems to be balanced with the assertion that all people have direct access to God. While the term "sovereignty of God" is not defined, the traditional meaning of the term is antithetical to the proposition that all people can come to God, which suggests that all people are capable, in some sense, of repenting and having faith, not just those whom God has predestined for eternal life. This in no way implies that salvation is earned, simply that it is available to all and withheld only from those who reject it.

Another similarity between the new mountain churches and other Baptists, both within and without West Virginia, was a concern for missions. Harmony Baptist specifically declared itself a missionary Baptist church. The church faithfully supported state, home (United States), and foreign missions. None of the other churches studied here specifically mentioned being a "missionary" Baptist church, although records show that all of them, from their formation, were involved in missionary endeavors at all levels and cooperated with the General Association and American Baptist Home Mission Society.

Simply joining an association affiliated with the General Association signified an interest in missions. Evangelizing the Mountain State was one of the major reasons for the formation of the General Association. The Jubilee meeting of the BGA in 1915 celebrated the history and success of Baptist missionary efforts over the previous fifty years. During the mid-antebellum period, mission and anti-mission Baptists had fellowshipped together in the Western Virginia Association, which formed in 1844 and lasted until 1850. The organization covered sixty 
counties, which contained roughly 8500 missionary Baptists and 2600 anti-mission Baptists. ${ }^{90}$ Dis-fellowship between the two groups began in the 1830, and by the 1850 s the separation was complete.

Anti-mission sentiment refused to go away, however. In the earliest years of the twentieth century, it was on the rise among churches in the General Association. John S. Stump, W.E. Powell's successor as state Superintendent of Missions, worried that anti-mission pastors were becoming increasingly common in missionary churches. His letter to the Home Mission Society in 1902 indicates that churches which had generously contributed to missions had called anti-mission pastors. He does not go into great detail, but the letters suggests that the people called these pastors not because congregations were changing their minds, but because the choice of pastors was so limited. Once in the pulpits, these preachers then attempted to limit and even halt support for missions. Apparently some ministers also believed they could draw families away from anti-mission churches if they downplayed or ignored missionary activities. ${ }^{91}$ Stump's concerns may have been unfounded. Missionary Baptists had always outnumbered their antimission brethren, and anti-mission numbers continued to decline into the twentieth century, while missionary Baptists prospered, bolstered by the support of the ABHMS.

Commitment to missions constituted one aspect in which Baptist churches in West Virginia, both new and existing bodies, remained connected to their counterparts in the rest of the United States, particularly those churches affiliated with the ABHMS. Despite the legacy of the anti-mission movement, the main strand of Baptists in America was mission-oriented. At the heart of this endeavor were the salvation of the individual and the formation of Baptist churches

\footnotetext{
${ }^{90}$ Hank, et al., 38-40.

91، Annual Report to the Board," Sixty-Eighth Annual Report of the American Baptist Home Mission Society (New York: ABHMS, 1902), 56, 57.
} 
that would preach the gospel and continue to evangelize in their communities. Missionaries and pastors met physical needs of their parishioners and participated in other aspects of local life, as in the case of Rev. Pack in Parsons. However, the preaching of the gospel and redemption of souls always remained the purpose of the local church.

\section{Baptists and Popular Religion}

Probing the records and histories of these Baptist churches clearly highlights the continuity of West Virginia Baptist beliefs, even in a rapidly-changing world. The General Association retained its autonomy and adapted to the times. While the Home Mission Society sent missionaries and money, the BGA was not financially or organizationally dependent upon the national group. The state and national bodies cooperated, with West Virginia Baptists helping to support the society's missionaries in the state by giving to the General Association's State Missions Board. ${ }^{92}$ While theological liberals became increasingly powerful in the national body, West Virginia Baptists remained faithful to their historic faith but desired organizational unity for the advancement of the gospel. A theological stance which became increasingly fundamentalist but which still sought denominational cooperation, coupled with a relatively moderate social position (discussed in Chapters $7 \& 8$ ), indicates a group of Baptists still within the mainline of American Protestantism at the time. The "Old Time Baptists" which receive so much treatment in the literature on Appalachian religion not only constituted a tiny fraction of the total number of Baptists in the state, but they were also almost non-existent in the highest and most remote parts of the state.

New local churches also exhibited the same dedication to traditional Baptist polity and theology as the older churches in the state, yet, it seemed that the people of the mountains were,

\footnotetext{
92، Annual Report to the Board," Sixty-Ninth Annual Report of the American Baptist Home Mission Society (New York: ABMHS, 1903), 47.
} 
on the whole, uninterested in Baptist teachings. With the exception of the First Baptist Church of Elkins, the Baptist churches along the WVC\&P mainline struggled. Other than the Elkins congregation, none of them had more than 100 members before 1920 . This hardly seems like an endorsement or manifestation of popular religion, but popular religion is about much more than which religion is most popular among the people. Sheer numbers are not the best measure of popular religion. Popular religiosity manifested itself in other ways in those elements of church life which facilitated intimate and meaningful participation and connection with other Christians, the church, and God.

Baptist churches in the mountains provided opportunities for those with the least amount of power in the secular world to exercise some in the sacred sphere. Most of the churches along the WVC\&P remained very small throughout the Gilded Age and Progressive Era. Membership continued to consist primarily of lower and lower-middle class people. Even though Elkins experienced significant growth after 1900, for the first decade of its existence, the Baptist Church of Elkins also consisted mostly of those from the lower social rungs. When membership grew, more elite people joined the church, but egalitarian polity remained, with people from all social classes exercising leadership in the church. Indeed, all of the new churches disregarded temporal status when determining who could serve in leadership roles within the church. This aspect of religious life is something many scholars of popular religion tend to overlook because of the focus given to the tension between popular religiosity and organized religion. This does not have to be the case. The highly decentralized nature of Baptist policy and the egalitarian constitution of its theology demonstrate that the individual was very much a part of the organization as both an institution and a community. 
Baptist ecclesiology is intricately connected with the democratic polity and theology of the denomination. The church is more than a place or a building; at its core, the church consists of believers gathered together. As Levonn Brown writes, "When Jesus used the word church, he was referring to a group of people whom he had called to be with him in special relationship."93 In the Baptist tradition, the emphasis is on groups of believers in individual local churches, rather than on all Christians world-wide. While each congregation is autonomous in relation to other congregations, it is still part of the body of Christ. This means that a local church must obey the will of Christ, but is free to do so as it sees fit. "It means that all of the members, and not just the minister or deacons or some committee, have a role in seeking the will of Christ," explains McBeth, arguing out that this was the New Testament pattern. ${ }^{94}$

Integral to this democratic conception of the church was the doctrine of the priesthood of the believer. This concept did not originate with Baptists, but it was foundational to their origins and has been central ever since, informing confessions of faith and church life and practice. In short, all people have access to God. Repentance and faith cannot be coerced. The believer, fellowshipping with other believers in a local church, is on equal spiritual footing with all other members of the congregation, regardless of social rank in the secular world. ${ }^{95}$ The entrance into the local church is the same for all - baptism. The statements of faith examined here, along with all Baptist confessions, are explicit on this subject. The newly-converted person joins the church through baptism. This act is an outward symbol of an inward change. Only the regenerate can

\footnotetext{
${ }^{93}$ Levonn D. Brown, “If This Is Not a Place," in Proclaiming the Baptist Vision: The Church, Walter B. Shurden, ed. (Macon: Smith \& Helwys Publishing, Inc., 1996), 61.

${ }^{94}$ H. Leon McBeth, "The Church: Community of Faith,” in Proclaiming the Baptist Vision: The Church, Walter B. Shurden, ed. (Macon: Smith \& Helwys Publishing, Inc., 1996), 21.

${ }^{95}$ Walter Shurden, “Introduction," Proclaiming the Baptist Vision: The Priesthood of All Believers, Walter B. Shurden, ed. (Macon: Smith \& Helwys Publishing, Inc., 1993), 3.
} 
truly be members of the church. However, as Baptist scholar R. Wayne Stacy notes, the act also has collective implications that are as important as the individualistic meanings. Baptism, he posits, "is, by its very nature, an act of community."96 Through this act, one joins the local church, which is a community of those obedient to Christ.

Because of equality within the body, leadership positions then became open to all, regardless of worldly station. No formal education or training was required. It was God's call, not human training, that ultimately qualified one for the positions of pastor/preacher and deacon, which were the two offices Baptists recognized as having Scriptural authorization. ${ }^{97}$ As pastor or deacon, a man served a true community, not just an institution. In a real sense, he was the spiritual heir of New Testament Christians - in the case of pastors and even licensed preachers, Timothy and Titus and in the case of deacons, Stephen and Philip. ${ }^{98}$

Even the clerical offices such as trustee, Sunday School Superintendent, clerk, and treasurer, which were not directly sanctioned by Scripture, still represented the choices and needs of the local congregation. In the case of the latter two, women were permitted to serve the church in these capacities. While women's roles in these congregations were still within classic Baptist understandings of gender roles, in most of the churches studied here, women were able to exercise the maximum amount of leadership and participation in the church afforded by their faith tradition.

The confessional tradition of West Virginia Baptists also sheds light on religion in Appalachia and can be used to understand popular religion in the region. The statement of faith

\footnotetext{
${ }^{96}$ R. Wayne Stacy, “A Baptist Theology of Baptism,” in Proclaiming the Baptist Vision: Baptism and the Lord's Supper, Walter B. Shurden, ed. (Macon, GA: Smith \& Helwys Publishing, Inc., 1999), 111.

${ }^{97}$ McBeth, The Baptist Heritage, 76.

${ }^{98}$ See I and II Timothy, Titus, and Acts 6-8.
} 
was at the center of church life. Like Primitives and Old Regulars, mainline Baptists continued to define themselves in confessional fashion. These confessions were more than dry theological tracts. They represented the living faith of everyday believers. They were also basic instructional tools for doctrinal education. As McBeth observes, "the confession not only expressed the Baptist faith but also helped formulate it." $" 99$

Charles Lippy points out the similarities between fundamentalism and popular religion. "At its base, fundamentalism was compatible with the religiosity of the people, for both assumed the reality of supernatural power and the prevalence of supernatural forces at work in the world," he argues. ${ }^{100}$ Well before the fundamentalist-modernist controversy of the 1920s, local Baptists in West Virginia, even in those churches formed when the social gospel was on the rise among Northern Baptists, affirmed the core doctrines that the fundamentalists fought hardest to defend. For Baptists, the heart of the matter seemed to be Scriptural authority. While other issues were certainly important, they all stemmed from the inspiration and inerrancy of the Bible. The first article of the New Hampshire Confession, and of the other confessions adopted by the churches examined here, was on Scripture, and it was around this articulation of the biblical inspiration and inerrancy that Northern Baptist fundamentalists rallied in the early 1920 s.

While Baptists were not known for overt supernatural workings of the Holy Spirit such as speaking in tongues or faith healing, they consistently attested to those actions of the Spirit which were common to every Christian as a called, repentant, faithful, and sealed child of God. In affirming the confession, the believer became an intimate part of the church as a community and as an institution. This confessional bond coupled with the opportunities and responsibilities of serving as deacon or clerk, for example, demonstrates how the church functioned as a link

\footnotetext{
${ }^{99}$ McBeth, The Baptist Heritage, 68.

${ }^{100}$ Charles Lippy, Being Religious, American Style (Westport, CT: Praeger, 1994), 167.
} 
between the natural and the supernatural, and how it could do so in a popular context. In a Baptist church, believers voluntarily came together as part of the body of Christ, submitting themselves to his lordship, expressing their particular faith, and living it by deciding among themselves how best to serve God.

\section{Conclusion}

The Gilded Age and Progressive Era were periods of both concentration and expansion. Government and business gained more power and extended their reach into American society and culture. Baptists were not immune to these trends. At the state and national levels, they concentrated their resources in order to expand their ministries. While substantial shifts occurred at the national level among Northern Baptists, West Virginia Baptists remained firmly grounded in their traditional ways. Even the newest churches in the state, which were also those in the most remote regions, quickly and readily affirmed the positions Baptists had held for centuries.

The study of these churches and the local and state associations with which they quickly united reveals strong religious similarities between West Virginia Baptists and those in rest of America at the beginning of heavy industrialization of the mountain state. Contrary to much of the literature, greater religious homogenization was not a product of the period. In fact, among Baptists quite the opposite is true. Although the period in question witnessed greater cooperation between state and national denominational agencies and increased centralization at the national level, it also witnessed the development of significant diversity in Baptist circles. The rise of liberalism and the social gospel divided Baptists in far more substantial ways than the antimission controversy or even the conflict over slavery before the Civil War.

The conservatism of the newest churches in West Virginia is perhaps best attributed to a combination of chronological, theological, and polity factors. Many were established while the 
social gospel was still in its infancy among Baptists. Furthermore, even after partnering with the American Baptist Home Mission Society, the state General Association retained control over choosing and sending missionaries. Thus, into the twentieth century conservative missionaries labored in the mountains, preaching the old-time religion. The fact that through 1920 most ordained Baptist pastors in America did not have formal religious or seminary training meant that ministerial exposure to new theological ideas was comparatively limited. Through the Progressive Era, pastors in general, especially those in rural areas, were consistently conservative, if not fundamentalist. ${ }^{101}$ Thus, traditional Baptist doctrines remained dominant in the state, even in those churches formed when theological liberalism was on the rise.

In addition to continual support of classic Baptist theology, West Virginia Baptists clung tenaciously to their distinctive polity. While allowing some greater cooperation with the national Baptist groups, the General Association and the local associations worked to preserve the autonomy of the local churches. Within individual congregations, men of all social ranks served as deacons, trustees, clerks, Sunday School Superintendents, and association messengers. Women were also able to wield a considerable amount of influence within local congregations, even if usually in administrative and organizational capacities and not in spiritual roles. Perhaps more importantly, the position of women in these churches seemed to be completely unrelated to the greater secular context in which the assembly was situated. Elkins, by far the most developed and populous city in the mountains, had the church with the most conservative stance on gender roles. The Grant County churches, all of which stood off the mainline, allowed women greater service and leadership opportunities.

The paucity of Old Time Baptists in the Allegheny region and the doctrinal similarities and organizational links between West Virginia Baptists as whole and their co-religionists in the ${ }^{101}$ A Genetic History of Baptist Thought, 384. 
rest of America at the dawn of the industrial era cast doubt on the effectiveness of the "mountain church tradition" paradigm to adequately explain and describe the nature of religion in the region. Instead, the concept of popular religion may be better suited to analyze the development of Protestantism in West Virginia during the late nineteenth and early twentieth centuries and draw connections between the secular and sacred in America. More of this second aim will come in Chapter 8.

The Baptists in the Alleghenies were largely middle and lower class, and most had very little if any formal religious education. They held to a faith honed over the centuries by educated clergy and trained theologians. Nevertheless, church polity allowed them to truly appropriate that faith, to make it their own through active participation in local congregations. The Baptist churches studied here indicate that mainline Baptist churches were by no means less Baptist or compromising on what they considered to be the central elements of their religion. What concentration and centralization occurred among Baptists at all levels did nothing to limit the ability of mainline Baptist churches to allow for manifestations of popular religion. In fact, it was popular religiosity which permitted Baptists in the Alleghenies, and in West Virginia in general, to meet the needs of the changing world around them as they deemed appropriate and still remain faithful to their religious heritage. 


\section{7: An Appalachian Social Gospel, or Becoming Fundamentalist?}

\section{Introduction}

Missionaries and church workers in the mountains labored during times of great social and economic upheaval. Indeed, many of them believed the changing times necessitated their work. Equally significant religious change occurred at the same time. Secular and sacred changes existed in a dialectical relationship, each serving simultaneously as both cause of and effect on the other. Because of this symbiosis, the shifting religious attitudes of the nation, particularly among certain segments of the population, played an important role in framing the mountain religious experience during the period. As a major development in American religious life, the social gospel movement affected all large, national, mainline American denominations, but it did not do so equally.

During the Gilded Age, many Americans, especially from the middle class, riding a wave of moral enthusiasm and idealism, stood ready to work for social reform. The social gospel sprang from this environment and quickly occupied a leading position in the quest for a just society. Originally referred to as social Christianity, the social gospel did not originate in a single American denomination, but rather arose out of concern for the impact of the industrial revolution and a renewed emphasis on the doctrine of the Kingdom of God (see Chapter 1). ${ }^{1}$

Several elements working together determined the extent to which a given denomination felt the influence of theological liberalism in general and the social gospel in particular. Geography constituted a major factor, one over which churches had little or no control. The social gospel exerted significant, and early, influence in the North. Due to rapid immigration and urbaniza-

\footnotetext{
${ }^{1}$ Robert T. Handy, ed. The Social Gospel in America (Oxford: New York, 1966), 4-11; Charles Howard Hopkins, The Rise of the Social Gospel in American Protestantism, 1865-1915 (New Haven: Yale University Press, 1940), 105, 106; Ronald C. White, Jr. and C. Howard Hopkins, The Social Gospel: Religion and Reform in Changing America (Philadelphia: Temple University Press, 1976), 81.
} 
tion, the problems which fueled the new movement confronted religious leaders and thinkers in the North, particularly in the Northeast and Midwest, more directly and powerfully than in other parts of the country. Thus, the northern wings of mainline Protestant denominations provided more fertile ground for progressive religion than did southern branches.

Denominational distinctiveness made up another major factor. Baptist, Methodist, and Presbyterian contributions to the social gospel during the late nineteenth and early twentieth centuries operated as functions of the unique characteristics and situations of each denomination as they did the products of individual talents and minds. Denominational histories, theologies, and practices conditioned the three major national mainline churches and their regional branches to deal with social issues and progressive religious developments in different ways. This meant the liberal/conservative divide, and later the modernist/fundamentalist divide, varied in degree and significance between the major mainline churches.

An overview of Baptist, Methodist, and Presbyterian interaction with the social gospel on a national level will demonstrate these differences. It will also provide the background for an examination of how each group dealt with the social gospel in the mountains of West Virginia. In turn, this more concentrated study will reveal the ways in which each church manifested popular religion. Studying this particular Appalachian response to the social gospel will help flesh out the religious atmosphere in the Mountain State in the early twentieth century and help situate religion as a bridge between Appalachian and American culture during the period. Finally, since the social gospel developed out of, and represents, the intersection between the sacred and secular, it offers a window into the religious mindset of West Virginia Protestants on the relationship between those two spheres and all that they entailed. 


\section{The Social Gospel: An Overview}

Congregationalists, a mainline denomination descended from the Puritans of Massachusetts, whose numbers and influence began to wane after the Civil War, made the pioneering contributions to social gospel thought. While other mainline denominations soon explored and developed this new school of thought in Christianity, Washington Gladden, Josiah Strong and Theodore Munger, all Congregationalist ministers, first applied the precepts of the Bible to the social and economic crisis of the Gilded Age and later Progressive Era, believing Christianity offered the best chance for peace and prosperity in an industrial nation. ${ }^{2}$ Munger was perhaps the most accomplished theologian of the three, while Gladden and Strong were more involved with social reform, albeit in moderate, if not conservative, forms. As such, these two men were concerned with the state of the ever-growing working class. Yet both saw socialism as dangerous. Rather, justice for laborers could be achieved in part by such things as labor unions, profit sharing, and serious anti-trust legislation and prosecution. While these positions represented a moderate political stance, a marked conservative strand remained among early social gospelers. Josiah Strong, for example, advocated a strong nationalism and argued for strict anti-immigration policies, equating Americanization with Christianization. ${ }^{3}$

Liberal theologians and social gospelers saw a strong connection between contemporary social issues and the doctrine of the Kingdom of God. Classical laissez-faire economics promoted individualism and a social order predicated on drastic wealth inequalities. With an otherworldly focus on individual salvation, some Christian denominations also promoted individual-

\footnotetext{
${ }^{2}$ Christopher H. Evans, Liberalism Without Illusions: Renewing an American Tradition (Waco: Baylor University Press, 2010), 56.

${ }^{3}$ Hopkins, 105; Gary Dorrien, The Making of American Liberal Theology: Imagining Progressive Religion, 18051900 (Louisville: Westminster/John Knox Press, 2001), 293-311.
} 
ism and deemphasized the collective and societal aspects of humanity. Even segments of the Methodist church, which had always emphasized social holiness, had become comfortable with the social structures that promoted vast wealth inequalities and other forms of social injustice. The work of individuals and private organizations, rather than comprehensive institutional reform, would be sufficient to handle the problems of industrialization and urbanization in a biblical a manner. ${ }^{4}$

American Protestants aware of the pressing social problems associated with industrialization and the rise of national corporations looked to theological liberalism to find the spiritual, hermeneutic, and doctrinal tools to approach the secular crisis. A new emphasis on the doctrine of the Kingdom of God constituted the central part of the social gospel from the very beginning. Reform may have constituted the ultimate end of this new social Christianity, but innovative approaches to doctrine drove these Christian reformers and radically altered the way they approached their work. It caused some Baptist and Presbyterian scholars, pastors, and theologians to seriously re-evaluate and re-prioritize the positions of their respective denominations. It caused some of their Methodist counterparts to renew and reinvigorate their Wesleyan social commitments to meet the needs of an industrial America. It was this theological revolution, discussed in more detail below, which distinguished the social gospel in the history of Christianity of in the United States. ${ }^{5}$

The idea of the Kingdom was nothing new to American Protestants. Christians of all stripes believed that at some point God would establish the kingdom on earth. At least as late as ${ }^{4}$ Christopher H. Evans, The Kingdom is Always but Coming: A Life of Walter Rauschenbusch (Grand Rapids: Eerdmans, 2004), 173.

${ }^{5}$ Dorrien, The Making of American Liberal Theology, Vol. 2, 311-314; Vol. 3, 293-341; Robin W. Lovin, "Moral Theology," in The Oxford Handbook of Methodist Studies, William J. Abraham and James E. Kirby, eds. (New York: Oxford University Press, 2009) ,653, 654; Charles Howard Hopkins, The Rise of the Social Gospel, 1856-1915 (New Haven: Yale University Press, 1940, 289-292, 310-311. 
the Gilded Age, the dominant belief concerning the kingdom among conservatives and liberals alike was postmilliennialism, the "theory that the second advent [of Christ] would climax, rather than commence, a thousand-year period of peace established by the forces of God." ${ }^{6}$ During the early and mid-nineteenth century German liberal theologians moved the Kingdom of God to the forefront of Christian thought and depicted Christianity in primarily social terms by accentuating the fatherhood of God and the brotherhood of man. Using the concept of the Kingdom, American Protestants welded together a desire to remedy social ills with social Christianity. Calls to Christianize society by conforming it and its various parts, both individual and collective, to the gospel resulted from this confluence of ideas and circumstances. By applying the gospel principles of love, justice, and brotherhood, social gospelers believed Christians could radically alter the social order and help inaugurate the kingdom on earth. ${ }^{7}$

This doctrinal shift precipitated by Protestant intellectuals' admiration for German theological liberalism had profound implications on American theology. The mature social gospel moved beyond the moralism of Gladden and Strong, offering a modern theology capable of responding to the modern world rather than simply a renewed emphasis on proper living and concern for one's neighbor. As Walter Rauschenbusch, Northern Baptist pastor, theologian, and professor, referring to the Kingdom of God, observed, "Here was the idea and purpose that had

\footnotetext{
${ }^{6}$ Jacob Henry Dorn, Washington Gladden: Prophet of the Social Gospel (Columbus: Ohio State University Press, 1967), 194; George M. Marsden, Fundamentalism and American Culture (New York: Oxford University Press, 2006), 48-55; Randall Balmer, The Making of Evangelicalism: From Revivalism to Politics and Beyond (Waco, TX: Baylor University Press, 2010), 32-35; Christopher H. Evans, Liberalism Without Illusions: Renewing an American Christian Tradition (Waco: Baylor University Press, 2010), 51.

${ }^{7}$ Dorn, 183; Christopher H. Evans, The Kingdom Is Always But Coming: A Life of Walter Rauschenbusch (Grand Rapids: Eerdmans, 2004), 231.
} 
dominated the mind of the Master himself. When the Kingdom of God dominated our landscape, the perspective of life shifted into a new alignment."

The Kingdom was inherently a social doctrine; it focused on the entirety of God's reign the "sum of all divine and righteous forces on earth" - and not just individual relationships to God. " "The Kingdom of God has taken the place of justification," Rauschenbusch observed in 1909 in comments concerning the theological tendencies of the previous century. "Religious individualism [belongs] to the old formulas." 10 Individualism dominated Protestantism because of the emphasis on the doctrine of justification. Furthermore, Biblicism and Calvinism undergirded this traditional Protestant focus and also represented "barriers to freer and more historically oriented ways of thinking.",11

This re-orientation resulted in the re-conception of both sin and salvation as social. Large groups and organizations, such as businesses, schools, and even governments -- what Rauschenbusch called "super-personal" forces -- must be brought under the law of Christ to operate by the principles of love and justice. Otherwise, they helped magnify, intensify, compound, and transmit the sins of individuals, thus further enslaving society to sin. Therefore, they must be made to

\footnotetext{
${ }^{8}$ Walter Rauschenbusch, Christianizing the Social Order, (New York: MacMillan, 1912), 93. See also Donovan Smucker, The Origin of Rauschenbusch's Social Ethic (London: McGill-Queen's Press, 1994), 87, 88.

${ }^{9}$ Walter Rauschenbusch, "The Kingdom of God," Brotherhood Leaflet No. 4, 1894; reprinted in Winthrop S. Hudson, ed., Walter Rauschenbusch: Selected Writings (Mahwah, NJ: Paulist Press, 1984), 78. See also Gary Dorrien, The Making of American Liberal Theology: Idealism, Realism, and Modernity, 1900-1950, 90-93 for a brief but detailed overview of Rauschenbusch's complex and sophisticated understanding of the Kingdom of God. His four-pillared view of the idea moved beyond the often one dimensional interpretations of both liberals and conservatives.

${ }^{10}$ Walter Rauschenbusch, “Theological Tendencies: 1814-1909," n.p. (1909), translated by Pat Thimme, manuscript copy in Box 99 in the Rauschenbusch Family Manuscript Collection, American Baptist Historical Society at Mercer University, Atlanta, Georgia.

${ }^{11}$ Rauschenbusch, “Theological Tendenices...," n.p.
} 
work for the Kingdom of God instead of for the Kingdom of Evil. ${ }^{12}$ Thus, the gospel was truly social. It was good news for society.

Social activism and reform per se were not inherently anathema to conservatives. Voluntary societies arose from the revival fires of the Second Great Awakening to fight a myriad of social vices and improve society through collective action. Theological conservatives backed not only missionary, Bible, and tract societies, they also joined the ranks of social liberals of the period in advocating for such things as temperance, education and prison reform, and moderate anti-slavery (e.g. colonization). To be clear, progressive theology certainly exerted an influence on reform movements, especially abolitionism. Antebellum "voluntaryism," however, was not primarily concerned with reconsidering doctrine. Rather, it was concerned with purifying society. ${ }^{13}$

From 1865-1930, a long, gradual process religious scholars call the "Great Reversal" occurred. During this period, conservatives and then fundamentalists slowly subordinated social concerns to individual ones until eventually social reform in general became suspect and in some quarters almost nonexistent. American religious historian George Marsden posits that this process took place in two phases and was extremely complex. The first phase, from 1865-1900, saw a shift from postmillienialism to premillienialism and from a Calvinistic view of politics to a pietistic one, as well as the increasing popularity of dispensationalism. The Civil War and the tu-

\footnotetext{
${ }^{12}$ Walter Rauschenbusch, A Theology for the Social Gospel (New York: Abingdon, 1917), 171.

${ }^{13}$ Ronald C. White, Jr. and C. Howard Hopkins, The Social Gospel: Religion and Reform in Changing America (Philadelphia: Temple University Press, 1976), 5-12; Kenneth J. Collins, Power, Politics, and the Fragmentation of Evangelicalism: From the Scopes Trial to the Obama Administration (Downers Grove, IL: IVP Academic, 2012), 49, 50. White and Hopkins note that abolitionists tended to scorn other reform and benevolence groups because of their willingness to cooperate with slaveholders. In fact, abolitionists formed their own missionary and tract societies, "establishing an alternate system to the American Protestant benevolent empire" and most closely presaging the social gospel emphasis on "the corporate nature of social evil." White and Hopkins, 16-18. For more on antebellum reform movements in general, see Donald Dayton, Discovering an Evangelical Heritage (Grand Rapids: Baker Academic, 1988); William G. McLoughlin, Revivals, Awakenings, and Reform (Chicago: The University of Chicago Press, 1978); David Brion Davis, ed., Ante-Bellum Reform (New York: Harper and Row, 1967); and Ronald G. Walters, The Antislavery Appeal: American Abolitionism after 1830 (New York: W.W. Norton and Company, 1984).
} 
mult of Reconstruction called into question the credibility of the postmillennial worldview. The world seemed to be getting worse, not better. This meant that many conservatives expected that only Christ could bring the Kingdom to earth, by initiating his 1000 year reign. The primary duty of Christians was to save souls; conditions on earth would increasingly deteriorate as the end neared. It also meant, as Marsden pointed out, that political action was seen simply as a means to restrain evil, not as a positive means to advance the Kingdom. ${ }^{14}$

These factors alone are insufficient explanations of the shift in attitudes about social reform. Even as the new understanding of the end times became more common in some mainline denominations, conservatives and fundamentalists still called for progressive reform. "The factor crucial to understanding the 'Great Reversal,' and especially in explaining its timing and exact shape, is the fundamentalist reaction to the liberal Social Gospel after 1900," Marsden argued. ${ }^{15}$ By World War I, social Christianity became completely identified with liberalism and occupied powerful positions in mainline denominational structures.

What bothered theological traditionalists were not really liberal calls for social improvement, but, rather, the doctrinal foundations which supported them. Many of the social gospelers reformulated Christian theology in a way that at the very least minimized the traditional focus on individual salvation. Liberals, therefore, approached social reform from a vastly different perspective than their fundamentalist counterparts. It was this difference which completed the

\footnotetext{
${ }^{14}$ Marsden, 91-93; David O. Moberg, The Great Reversal: Evangelism Versus Social Concern (Philadelphia: Lippincott, 1972), 34-38; Timothy P. Weber, Living in the Shadow of the Second Coming: American Premillenialism, 1875-1925 (New York: Oxford University Press, 1979), 41. Modern dispensationalism was a form of premillenialism that took root in America in the 1870s and grew steadily over the ensuing decades. It was pioneered by Irishman John Nelson Darby in the 1830s and later British and American theologians modified and refined the concept. Briefly, dispensationalism views the entirety of human history divided into distinct arrangements used by God to regulate the way humans relate to Him. Within this broad framework, however, adherents have developed a complex theology. For more on this, see, among others, Weber and Charles Ryrie, Dispensationalism (Chicago: Moody Press, 2007) and Craig C. Hill, In God's Time: The Bible and the Future (Grand Rapids: Eerdmans, 2002).

${ }^{15}$ Marsden, 91.
} 
"Great Reversal" over the first three decades of the twentieth century. While each denomination experienced this phenomenon in different ways, generally speaking, the "Great Reversal" opened a wide chasm between liberals and conservatives and severed links between orthopraxy and orthodoxy in much of American Protestantism. ${ }^{16}$

The "Great Reversal" paradigm is useful for broadly examining the sweeping changes occurring in American religious life in the Gilded Age and the Progressive Era. A unique theological gulf opened during the period, and that development had profound effects on American Christianity. At the state and local levels, and in some cases the national level, the "Great Reversal" is not always nuanced enough to deal with the diversity of mainline Protestantism. Methodists, Baptists, and Presbyterians in West Virginia acknowledged and participated in the changes occurring in the secular and sacred spheres. Their beliefs and actions are difficult to dichotomize, and the "Great Reversal" concept can actually obscure more than it reveals. The religious progression in the mountains at this time should not be seen as action-reaction. Rather, it should be seen as simply action, with each group demonstrating flexibility and faithfulness in handling the challenges of industrialization and modernization.

\section{Methodists}

Historically, Methodists saw no distinction or contradiction between orthopraxy and orthodoxy. Founder John Wesley maintained a strong commitment to sound theology and to social activism. "The Gospel of Christ knows no religion but social; no holiness, but social holiness," he maintained. ${ }^{17}$ Wesley's social theology should not be equated with the social gospel, but the

\footnotetext{
${ }^{16}$ Marsden, 91-93; Collins, 51

${ }^{17}$ Quoted in Georgia Harkness, The Methodist Church in Social Thought and Action (Nashville: Abingdon Press, 1964), 94, 95. For more on the origins of Methodism and Wesleyan theology, see, among many others, David Hempton, Methodism: Empire of the Spirit (New Haven: Yale University Press, 2005) and Richard P. Heitzenrater, Wesley and the People Called Methodists (Nashville: Abingdon Press, 1995).
} 
various branches of Methodism in America carried on this legacy of comprehensive and integrative theology. It spanned the breaches between the ME Church, and the ME Church, South. This close connection between doctrine and action reached from the General Conferences down through the denominational hierarchy to the local churches, although the specifics in how this belief was applied were not always the same.

However, as the early years of the 1900s passed, this unity began to fracture. The social gospel and its attendant liberal theology made greater headways into the MEC, while Southern Methodists, while still expressing social concern, became increasingly suspicious of new theology. In any case, the relationship between thought and deed in Methodism complicates the basic narrative of the Great Reversal. At the same time, it shows how believers at the state and local levels exercised considerable autonomy in determining how they would exercise their faith.

Methodist scholars agree that while theological liberalism and the social gospel slowly gained acceptance in their church (even in the North), the heirs of Wesley consistently maintained a clear social stance and were willing to adapt that position to new social and economic realities. ${ }^{18}$ All of the major strands of American Methodism supported nineteenth century causes such as temperance and Sabbath reform, but when new social and economic realities arose in the Gilded Age, Methodism, in general and unevenly, rose to the challenge of responding with and through the Christian message.

The Methodist Episcopal Church first gave official attention to the urbanization and industrialization occurring in the Northern states in 1888. In a subsection of the Bishops' Address entitled "Labor Problem," the episcopal leaders recognized the growing divide between labor and capital, a chasm which had increased since the Haymarket Riot two years earlier. The

\footnotetext{
${ }^{18}$ Russell, E. Richey, Kenneth E. Rowe, and Jean Miller Schmidt, The Methodist Experience in America: A History, Vol. 1 (Nashville: Abingdon Press, 2010), 300.
} 
church maintained it was not commenting on political issues, nor was it taking sides. Both sides suffered from corruption, or at least the potential to become corrupt. As a spiritual body, the MEC believed it had the answer. Both sides must "be governed by the Spirit of Christ."19

This sentiment should not be equated with the social gospel, although it revealed a real social awareness that transcended narrower doctrinal controversies. It coincided with the sprouting of decidedly social gospel thought within the denomination. It would take more than a decade for a Methodist social gospel to mature, but once it did it, became a driving force within the denomination. Classic Methodist practices blended easily with the social gospel. Wesleyan custom combined Scripture, reason, tradition, and experience of the divine into a four-part locus of spiritual authority, although Scripture remained the primary source of Christian authority. ${ }^{20}$ In the face of new scientific evidence and changing economic and social conditions, Methodists possessed considerable resources to deal with innovation, while still retaining strong ties to their roots.

Well before the full flowering of social gospel thought in the North, the General Conference made increasingly detailed statements about social conditions in America. While elements of other major Protestant denominations acted in the same way, the MEC was the first such group to officially issue such forthright declarations about increasing injustice and inequality. In 1892, the Bishops called on all clergy to preach against mass accumulation of wealth. The church must remain true to Scriptural principles, and this meant helping the poor, many of whom were racial and ethnic minorities. Thus, the church recognized that, in many ways, racial and economic issues were connected. ${ }^{21}$

\footnotetext{
19“'Bishops' Address,” Journal of the General Conference of the Methodist Episcopal Church, 1888, 55-60.

${ }^{20}$ Richard P. Heitzenrater, Wesley and the People Called Methodists (Nashville: Abingdon Press, 1995$), 318,319$.

21،'Bishops' Address," Journal of the General Conference of the Methodist Episcopal Church, 1892, 62-65.
} 
By the turn of the century, however, more decidedly social gospel thought pervaded the denomination as a whole. The General Conference issued statements on the social duty of Christians. The church was not a political entity, nor would it champion various social theories. It did not need them. It had the truth of the gospel and must use that to mediate between capital and labor. It would side with neither; rather, it would work to bring both sides to the side of Christ. "Never, until the Church shall lay the Golden Rule upon the conscience of capitalists and laborers, will the golden millennium of industrial peace be ushered in," read a report on the current state of the country. ${ }^{22}$

Some key social gospel elements stood out in the segments of the speech. Phrases such as "millennium of industrial peace" and "social millennium" moved beyond the traditional postmillennialism of Methodism to a postulate a specific vision of the kingdom on earth set in the context of Gilded Age and Progressive Era America. Furthermore, the basis of the church's action was "the one supreme relation among men, which is Brotherhood." 23 The concept of the brotherhood of man, with the related idea of the fatherhood of God, constituted one of the foundational pillars of the theological liberalism undergirding the social gospel.

The social gospel became fully integrated and institutionalized in the Methodist Episcopal Church in 1908 when it adopted the Social Creed. The year before, churchmen desiring an even more complex and concrete social stance formed the Methodist Federation for Social Service (MFSS). Led by Frank Mason North, Harry F. Ward, and others, the group saw itself as the product of escalating trans-Methodist and trans-Atlantic public ministry. Ward took the lead in

\footnotetext{
22،"Some of the Evils and Perils of Our Age," Journal of the General Conference of the Methodist Episcopal Church, 1904, 139-149; "Bishops' Address," Journal of the General Conference of the Methodist Episcopal Church, 1900, 69-72.

23،"Bishops' Address," Journal of the General Conference of the Methodist Episcopal Church, 1900, 69-72.
} 
drafting the Social Creed, a succinct, eleven-point statement outlining a vision for the MEC, often hailed as "the preeminent summation of the social gospel.".24

The document called for "[e]qual rights and justice for all men in all stations of life" and for "the recognition of the Golden Rule and the mind of Christ as the supreme law of society and the sure remedy for all social ills. ${ }^{25}$ While the Creed also advocated for fairness in adjudicating labor and business disputes, the overwhelming majority of the points supported various positions of organized labor against businesses. North added four more points to the text: the right to a job, unemployment compensation, old age/disability insurance, and aid to dependent children. The Federal Council of Churches, of which the MEC was a founding member, adopted this augmented version. ${ }^{26}$

The connectional system afforded Methodists an excellent means of cooperation and coordination of resources and talents. The General Conference created numerous programs for a wide variety of causes in the 1910s and 1920s. Various annual conferences also expanded their social ministries, some of which predated General Conference activity by years. The hierarchical structure of the church could have allowed the social gospel to spread like wild fire, but that same system allowed considerable autonomy to lower power structures and considerable diversity in belief. Historic Methodist attitudes about the relation of doctrine and practice meant the ideas in the Social Creed did not seem as radical to conservative Methodists as they did to con-

\footnotetext{
${ }^{24}$ Frederick A. Norwood, The Story of American Methodism (Nashville: Abingdon Press, 1979), 392, 393. See also "Bishops' Address," Journal of the General Conference of the Methodist Episcopal Church, 1908, 136, 137. The MFSS was and is not under the control of the General Conference.

${ }^{25}$ Harkness, 47.

${ }^{26}$ Richey, et. al., 325. Both North and Ward had extensive careers in the Methodist Episcopal Church and the Federal Council of Churches. For more on their lives and thought, see Gary Dorrien, The Making of American Liberal Theology: Idealism, Realism, and Modernity (Louisville: Westminster John Knox, 2003), 107, 294, 295, 396. See also Doug Rossinow, "The Radicalization of the Social Gospel: Harry F. Ward and the Search for a New Social Order, 1898-1936," Religion and American Culture: A Journal of Interpretation 15, No. 1 (Winter 2005) : 63-106.
} 
servatives in other denominations. In fact, conservatives within the denomination voiced little opposition to the propositions voiced in the Social Creed.

In the early years of the twentieth century, conservatives focused their attention on a distinctly theological and philosophical development they believed constituted a much more significant threat to true Methodism than the Social Creed. In 1904, conservatives brought Borden Parker Bowne before the New York East Conference (the very conference in which Frank Mason North worked) on heresy charges, alleging he held and taught aberrant views on sin, salvation, the Bible, sanctification, and a number of other doctrines, both primary and secondary. Bowne availed himself well, was acquitted, and returned to his teaching post at Boston University. ${ }^{27}$

The rise of the social gospel, Bowne's acquittal, and the subsequent rise of theological liberalism in the MEC left little room for fundamentalism. In the 1910s and especially in the 1920s, some conservative stalwarts strenuously objected to the direction in which their denomination headed. Led by Harold Sloan and Clarence True Wilson, fundamentalists sent a number of complaints to the 1920 General Conference about textbooks used at Drew University, a Methodist institution of higher education. The body stipulated that books must be in accordance with church teaching, but did not ban any. Four years later, it laid the matter to rest, refusing to ban books and decrying "heresy-hunting.,"28

\footnotetext{
${ }^{27}$ Richey, et. al., 301. For an abridged transcript of the trial, see Russell E. Richey, Kenneth E. Rowe, and Jean Miller Schmidt, The Methodist Experience in America: A Sourcebook, Vol. 2 (Nashville: Abingdon Press, 2000), 460-464. For more on Bowne's theological positions, see Gary Dorrien, The Making of American Liberal Theology: Idealism, Realism, and Modernity (Louisville: Westminster John Knox, 2003). Social gospelers in the denomination found some elements of his personal idealism attractive, although Bowne himself had only a sporadic interest in broader collective matters. It was left to students of Bowne such as Albert Knudson, Franklin Rall, and Edwin Lewis to synthesize social thought with the inward looking nature of Boston Personalism, Bowne's principle contribution to modern theology. See also Norwood, 319.

${ }^{28}$ Norwood, 384-386.
} 
Through the 1920s, the Methodist Episcopal Church would remain big enough for everyone. As George Marsden pointed out, "Methodism was too little oriented toward strict doctrinal definitions for its fundamentalists to grow to large numbers or to have much impact." ${ }^{29}$ Following Donald Dayton, Methodist scholar Kenneth Collins also notes that fundamentalism influenced denominations more closely tied to the Reformed tradition, such as Baptists and Presbyterians, much more than it did those in the Wesleyan heritage.$^{30}$ This picture of Methodists, and those of Baptists and Presbyterians to follow, seems to support these claims.

Fundamentalists by no means went away, and some churches, districts, and annual conferences remained essentially conservative. While liberals occupied many big-city pulpits and faculty positions at major seminaries and universities, the denomination as a whole remained tradition-minded enough to maintain a broad theological balance and a broad commitment to social reform. Even those annual conferences which did not accept theological liberalism or the social gospel did not retreat from social causes because of a firm grounding in the Wesleyan tradition. Thus, for the MEC, the notion of the Great Reversal may not really apply.

The Methodists in the mountains of West Virginia substantiate these observations. In the MEC, three different annual conferences claimed the various churches in the five counties studied here. Until 1905, Pocahontas County belonged to the Virginia Conference. The next year, Pocahontas County churches joined the West Virginia Conference, which already included Randolph and Tucker counties. The Baltimore Conference claimed Grant and Mineral counties. In

\footnotetext{
${ }^{29}$ Marsden, 178.

${ }^{30}$ Kenneth Collins, The Evangelical Moment; The Promise of an American Religion (Grand Rapids: Baker, 2005), 36-38. Note in the text that while Marsden and Collins agree that Methodists were not prone to fundamentalism, they disagree on the exact reasons why that is so.
} 
1906, it surrendered Grant to the West Virginia Conference as well, while retaining Mineral through the Progressive Era. ${ }^{31}$

The railroad and the extractive industries it supported held even greater sway and made a deeper impact in territory of the West Virginia Conference. As more people entered the state and as mining and timbering continued to develop, the local churches, various districts, and women's groups reached out to help and evangelize the growing industrial population, including blacks and ethnic minorities. By 1910, for example, the Oakland district, which included Tucker and Grant counties, had a ministry to Italian immigrants. ${ }^{32}$ However, discrete social gospel influences probably exerted much less influence on local Methodist behavior than traditional Wesleyan ideas of social holiness. Neither the Social Creed, nor any reference to it, nor any acknowledgement of the work of the Federal Council of Churches, appeared in conference records. ${ }^{33}$ Despite its outreach to immigrant communities, this segment of West Virginia Methodism seemed reluctant to take a stand on the actual conditions and effects of industrialization. Tem-

\footnotetext{
${ }^{31}$ Given that it disbanded in 1906, two years before the General Conference adopted the Social Creed, it should come as little surprise that the Virginia Conference developed little appreciation for "the social question." Although the railroad, mining, timbering, and other heavy industries had long since established themselves in the mountain regions of the conference, the body as a whole and its several districts remained wedded to more traditional forms of community engagement. During its nearly forty-year ministry, the annual conference saw temperance and Sabbath reform as the primary avenues for public involvement. The report on "Reforms" in 1905 simply called on labor and capital to refrain from violating the Sabbath. See Raymond Fitzhugh Wrenn, "The Virginia Conference of the Methodist Episcopal Church, 1867-1906," in Those Incredible Methodists: A History of the Baltimore Conference of the United Methodist Church, Gordon Pratt Baker, ed., (Baltimore: Commission on Archives and History: The Baltimore Conference, 1972), 279; "Reform," Minutes of the Virginia Conference, Methodist Episcopal Church, $1905,47,48$.

32،"Oakland District Report," Official Journal of the West Virginia Conference, Methodist Episcopal Church, 1910, $15,16$.

${ }^{33}$ For the most part, the social gospel as such among West Virginia Methodists during most of the Gilded Age and Progressive Era seemed confined to academia. The Buckhannon District report of 1912 indicated that West Virginia Wesleyan College, located in Buckhannon, Upshur County, assigned social gospel texts in some courses. The report caused no great stir. Members of the MEC in West Virginia, like their co-religionists across the country, maintained a basically conservative theological stance. They made no overt moves toward theological liberalism, but expressed no dismay that material which may advocate that theology was being used in their institutions of higher education. See "Buckhannon District Report," Official Journal of the West Virginia Methodist Conference, Methodist Episcopal Church, 1912, 17.
} 
perance and Sabbath reform dominated their minds well into the twentieth century. However, when they finally addressed the modern economic order, they steeped their affirmations in the social gospel. In 1920, the annual conference endorsed a resolution drafted by the Ohio Valley Trades and Labor Assembly. The first plank stated that "the teachings of Christ constitute a platform upon which all men can agree." Thus, "they can be applied to modern industrial problems. ${ }^{34}$

The conference seemed to take no further action on this declaration, but a uniquely social gospel approach to the problems of modern America remained entrenched in the state denomination, even if its theology remained, on the whole, right of center. In 1930, for example, the District Superintendents' report noted that the church must pay careful attention to the situation of industry in the state because of the close relationship between West Virginia and business. In uncertain economic times, vigilance was all the more important. ${ }^{35}$

The Baltimore Conference included a more urban and diverse population than either the old Virginia Conference or the West Virginia Conference. In some ways, the social gospel made a much bigger imprint on that conference than it did on the other two discussed here. However, the level of social concern evidenced by that body did not always seem commensurate with the ideological influence of the social gospel. At the same time, theological liberalism by no means completely replaced traditional doctrinal understandings.

The Baltimore Conference included only a handful of counties in West Virginia, and after 1906, only one of those studied here. The lack of local church and district records makes it difficult to determine the extent of influences evident at the annual conference level. Nevertheless,

\footnotetext{
34"The Attitude of Labor," Official Journal of the West Virginia Conference, Methodist Episcopal Church, 1920, 50, 51.

35“"Bishop's Address," Official Journal of the West Virginia Conference, Methodist Episcopal Church, 1930, 63.
} 
the situation in the Baltimore Conference highlights how Methodism makes drawing clear lines between conservatism and the social gospel extremely difficult.

Temperance and Sabbath concerns dominated the conference's public ministry into the first decade of the twentieth century. The area boasted active women's groups, as well as freedmen's aid societies. Without retreating on these traditional Methodist issues, the conference adopted the Social Creed and created a Commission on Social Service in $1912 .{ }^{36}$ Its first report, issued in 1916, contained the purest essence of the social gospel, as well as a vigorous social commitment. "The Kingdom of Heaven is the will of God realized in our social relationships," it read. In seeking to remedy the ills of society, the commission also believed new measures could augment the old "new measures." "Social service is real evangelistic conservation. The revival passes and is lost unless the social environment is made to conserve its results. ${ }^{, 37}$ The church declared its commitment to work against evil in all facets of American life and expressed a willingness to work with other groups seeking the same end.

The commission and its work embedded the social gospel, both in doctrine and in practice, within the annual conference. At the same time, however, the conference showed a conservative side. In 1916, the same year the Commission on Social Service issued its first report, the annual conference also adopted a report from the Sunday School board about the need for better literature. The board expressed concern over new and confusing literature being used in Methodist adult Sunday Schools. "[T]he doctrines emphasized by Mr. Wesley and the Methodist

\footnotetext{
36، Commission on Social Service," Minutes of the Baltimore Conference of the Methodist Episcopal Church, 1912, 48.

37"Commission on Social Service," Minutes of the Baltimore Conference of the Methodist Episcopal Church, 1916, 81. For more on the social gospel in the Baltimore Conference, see Asbury Smith, "A Century of Developing Concerns, 1865-1965," in Those Incredible Methodists, 423. "The State of the Nation," Minutes of the Baltimore Conference of the Methodist Episcopal Church, 1921, 195; and "The State of the Church," Minutes of the Baltimore Conference of the Methodist Episcopal Church, 1922, 349, 350.
} 
Church [should] be emphasized also in our Methodist Sunday Schools." the report asserted. The function of the Sunday School and its material was to teach the "the Bible as The Book, the revealed and inspired Word of God." Only that truth would "save our people from confusion and establish their goings." 38

This simultaneous affirmation of the social gospel and use of fundamentalist-leaning language is puzzling on one level. Clearly the Baltimore Conference expressed a new understanding of the kingdom that moved beyond standard postmillennialism, but the Sunday School report, which was the only report addressing doctrine that was issued during the period, suggested it did not want to embrace liberal theology fully. When these competing views are held up to traditional Methodist beliefs, the tension disappears; the Baltimore Conference went further than both the West Virginia Conference and West Virginia Southern Methodists in its stance on social issues and their remedy. In ways similar to the MEC, they opted for a conciliatory approach which sought to synthesize basic social gospel beliefs and language about the kingdom and the importance of Christianizing society with a high view of Scripture and the accuracy of its teachings. In this way, the annual conference highlights a trend Marsden observed in the MEC - a fidelity to classic orthodoxy and orthopraxy combined with a generous openness to new approaches to new problems.

In addition to its general silence on doctrine, the conference's record on social action reflected this moderate stance. Despite the optimism of the Social Service report, the commission did little in the way of actual service. It did not even issue regular reports. In lieu of this, the

\footnotetext{
38"Sunday Schools," Minutes of the Baltimore Conference of the Methodist Episcopal Church, 1916, 77, 78. Emphasis is in the original. Collins notes that many church historians and theologians, both within and without the Wesleyan tradition, have observed that this type of fundamentalist language about the inerrancy of Scripture, which also became increasingly common in holiness denominations in the $1920 \mathrm{~s}$, did not accurately reflect the historic Wesleyan understanding of the Bible. Thus, such language really does reflect a fundamentalist influence, although it should not be construed as evidence of the existence of a militant power block within the denomination. See Collins, The Evangelical Moment, 70-78.
} 
annual conference as a whole issued few statements on labor or any other aspect of "the social question." It used the language of the social gospel, but rarely applied it to specific situations. As conference historian Asbury Smith noted, "The conference had very little to say about labor during the period." 39

Since that conference contained just a handful of churches in the mountain counties that are the subject of this study, it is reasonable to conclude that social gospel influences upon those churches were minimal at best, especially considering that the Commission on Social Service confined its activity to urban areas to the east. Nevertheless, an examination of the Baltimore Conference suggests some exposure to new theological influences, as well as a wide-spread commitment to historical Methodist understandings of doctrine and social action. The same can be said of mountain Methodists in the West Virginia Conference. Finally, at least at the time during which the Great Reversal was supposedly occurring, Methodists in the Baltimore Conference (MEC), and to a lesser extent the West Virginia Conference, saw no contradiction between continued adherence to classical Methodist theology and concerted efforts to solve the various social problems of the period.

A mix of cultural and religious conservatism that at times bordered on fundamentalism occupied a much stronger position in the Methodist Episcopal Church, South, but lacked the opportunity to sharpen itself against a concentrated theological liberalism. ${ }^{40}$ In terms of practice, Southern Methodists voiced concern for social issues in a much more traditional manner than did their coreligionists in the MEC. ${ }^{41}$ The General Conference did not even acknowledge an aware-

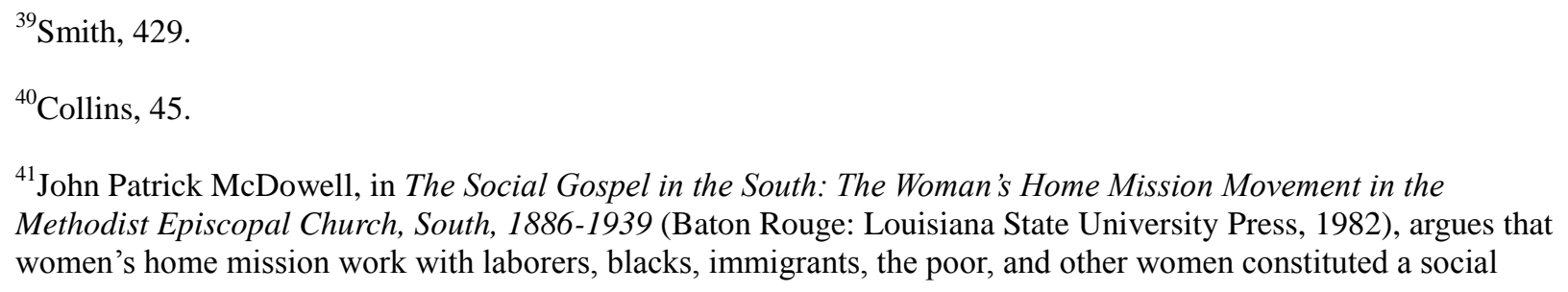


ness of the changing political, economic, and social climate of the country until 1894. Even then, it simply affirmed that the church was not a political body and that people must let their consciences guide them in non-religious matters. The Bishops' Address of 1906 recognized the breathtaking speed with which the country had industrialized and created a materialistic spirit in America antithetical to the kingdom of Christ. The statement avoided making any direct claim about wealth itself. Wealth simply must not be used to oppress the poor. ${ }^{42}$

Two years later, the MEC, South joined the Federal Council of Churches. The denomination endorsed the idea of ecumenism, but its social stance, still in many ways shaped largely by paternalism, lagged behind that of the MEC. Well into the second decade of the twentieth century, Southern Methodists emphasized nineteenth century reform issues such as temperance and Sabbath keeping. In addition to education, they also took an increasing interest in evangelization and uplift of African Americans, portraying themselves as the "best friend[s] of the Negro."43

Finally, with the adoption of the Social Creed in 1914, the General Conference took steps to address the new social issues of the period. While it still remained anchored to traditional approaches, Southern Methodist public theology began to broaden, albeit slowly. Nearly twenty years after declaring the church a purely spiritual body, the General Conference finally formally recognized what by then was old news to much of America. Men with inordinate amounts of wealth had elevated "the commercial world above the spiritual" and the "exigencies

gospel presence in the MEC, South. While influenced by contemporary social gospel thought, this work grew out of the Wesleyan tradition. Despite effective ministry, these groups exerted little theological influence over the annual conferences or the General Conference, and thus it would be inaccurate to say they led the denomination toward theological liberalism. For more on gender and the social gospel, see Wendy J. Deichmann Edwards and Carolyn De Swarte Gifford, eds., Gender and the Social Gospel (Chicago: University of Illinois Press, 2003).

42،"The Bishops' Address," Journal of the General Conference of the Methodist Episcopal Church, South, 1906, 3032.

${ }^{43}$ Harkness, 54; “Bishops' Address," Journal of the General Conference of the Methodist Episcopal Church, South, $1910,20-22$. 
of trade" over the "laws of the kingdom of heaven," the Bishops' Address stated. The bishops still maintained that the church "cannot serve as the partisan of a class, whether rich or poor. ... It is her office to inspire spiritual ideals among all classes and to proclaim Christian principles of life rather than to work out details of procedure and insist upon rigid methods and procrustean programmes [sic] for the settlement of all social issues," the address concluded. ${ }^{44}$

It would be inaccurate to say that any of the major Protestant denominations, on a national level, chose sides on "the social question." However, many of them did, at different times, come down moderately on the side of labor. They did not condemn capitalism as such, nor industrialization. Rather, they firmly declared the worker must be guaranteed rights commensurate with his or her job and position in society. That was the aim of the Social Creed. It was not until 1922, however, that the MEC, South clearly and strongly articulated this position. The Southern church believed workers' desire for "a righteous compensation" and "a safe and intelligent family life" was "just and worthy of respect on the part of all Christian Churches." 45

At the same time, one must not assume a strong fundamentalist presence in the organization either. Richey, Rowe, and Schmidt astutely pointed out that purely theological fundamentalism exerted far less influence on the denomination than other concerns, many of them cultural. Temperance and other older moral and societal issues anchored the antimodernist position, as drunkenness and Sabbath-breaking were associated with Europeans and immigrants, who were associated with urbanization and Roman Catholicism. These associations caused stiff opposition to unification with the MEC in the 1920s and early 1930s. ${ }^{46}$ Thus, while theological issues cer-

\footnotetext{
44،"Bishops' Address," Journal of the General Conference of the Methodist Episcopal Church, South, 1914, 30, 31.

45"The Church and the Industrial Question," Journal of the General Conference of the Methodist Episcopal Church, South, 1922, 358, 359.

${ }^{46}$ Richey, et. al., 341, 342. These authors also argue that the departure from the MECS of the holiness movement followers in the 1890s siphoned off leaders, lay and clergy, that might have been more doctrinally militant.
} 
tainly registered with Southern Methodists, and while they continued to adhere to traditional understandings of Christianity, most of the militancy, such as it was, derived from other sources that held theology of secondary, not primary, importance.

Unfortunately, available records from local churches and districts do not contain information on doctrine and practice. Like the Methodist Episcopal Church after 1905, the Southern Methodist churches in the Alleghenies in West Virginia were split between two conferences - the Western Virginia Conference, which encompassed Randolph and Tucker counties, and the Baltimore Conference, which included Pocahontas, Grant, and Mineral counties. The former stretched from the Allegheny Mountains west to the Ohio Valley, while the latter extended northeast from the mountains to the Delmarva Peninsula. Thus, the specific voice of mountain Methodists on theology and the social gospel can be difficult to hear. However, examining the proceedings of the two annual conferences provides a context for the particular set of counties examined here. That evidence indicates these annual conferences and their constituent districts mirrored the conservatism of the General Conference, gradually increasing their social witness as the time dictated but refraining from adopting the new theology often associated with such activism.

Like other American Methodists, the Western Virginia Conference devoted considerable attention to temperance and Sabbath reform. Evangelism and Sunday schools constituted two distinctly sacred means the group used to combat the vices of drinking, gambling, and Sunday leisure. Despite the fact that the conference included major timber and coal counties, it made no mention of the industrial and social issues facing the state. The home mission board created an Italian ministry in response to the increasing number of immigrants in the state, but that seemed to stem from traditional Methodist ideas of social holiness, not newer ideas about the social gos- 
pel. ${ }^{47}$ Records show no evidence of adoption or even acknowledgement of the Social Creed.

The only hint of ecumenism was the eagerness to cooperate with the MEC and the Methodist Protestant Church in West Virginia, as well as to contemplate reunion with their co-religionists. ${ }^{48}$

In 1918, Board of Temperance added Social Reform to its name. However, the board continued to discuss only temperance. Even after ratification of the Eighteenth Amendment, it focused on enforcing the laws and cracking down on bootlegging and corruption. As late as 1930, neither the Board of Temperance and Social Reform nor any other board or committee within the Western Virginia Conference made any mention of the problems unique to an industrial society, whether rural or urban. The Great Depression and its crippling impact on the state apparently merited no mention either.

Southern Methodists made only one official statement on the theological controversies of the period. They rejected any teaching or view which questioned the historicity of the Old Testament, especially Genesis, or which in any other way denied "the inspiration of the Bible, the Deity of Christ, his Virgin Birth, [and] the atonement for sin." Such positions came from "minds that have been warped by the teachings of the rationalists, agnostics and infidels." While not wishing to restrict freedom of conscience, the annual conference called upon the General Conference and other appropriate authorities to remove such people from their positions, declaring

\footnotetext{
47" Report of the Board of Home Missions," Western Virginia Conference Journal, Methodist Episcopal Church, South, 1910, 30, 31.

48،"Report of the Committee on Inter-Church Federation," Western Virginia Conference Journal, Methodist Episcopal Church, South, 1910, 34, 35. In 1939, the MEC, the MECS, and the MP Church united to form the Methodist Church. In 1968, the Evangelical United Brethren joined and the resulting denomination became the United Methodist Church.
} 
that "no man can hold such views and remain a consistent member of the Methodist Episcopal Church, South.",49

The annual conference never repeated this type of statement. Furthermore, it seemed to be grounded in genuine theological involvement, and not some marginally-related social or cultural element. This, coupled with the complete silence on matters pertaining to the Social Creed, suggests Southern Methodists in the Alleghenies, along with those in the other parts of West Virginia, remained consistently conservative throughout the early twentieth century. The three other counties studied here belonged to the Baltimore Conference, which included a much more diverse cross-section of society. It included farmers, miners, and timber workers in the Alleghenies, Blue Ridge, and Valley of Virginia, native-born whites from northern Virginia and the Chesapeake, and industrial laborers and immigrants from Baltimore. Given this constituency, the Baltimore Conference might be expected to be more vocal on social issues than the Western Virginia Conference and maybe even more open to new theological positions.

However, while the Baltimore Conference never addressed theological issues one way or the other, it also seldom addressed social ones. It never addressed the Social Creed. In 1911, it commended the work of the Federal Council of Churches, but not say anything specific. Not until 1920 did it add "Social Service" to the Report on Temperance. ${ }^{50}$ Even then, it focused solely on getting the Eighteenth Amendment ratified and subsequently enforced. Like the Western Virginia Conference, it did not make broader statements about the new realities in industrial Ameri-

\footnotetext{
49،"Resolution No. 2," Western Virginia Conference Journal, Methodist Episcopal Church, South, 1923, 41-43. This terminology regarding the Bible would be another example of language inconsistent with the thought of John Wesley.

50،"Report on Temperance," Minutes of the Baltimore Conference, Methodist Episcopal Church, South, 1911, 84; "Report on Temperance and Social Service," 1920, 66.
} 
ca. Making occasional statements on race and worrying about the moral dangers of dancing and the movie industry merited much more frequent mention into the late $1920 \mathrm{~s}^{51}$

Of course, the paucity of involvement in West Virginia and the mountain region in particular raises questions about how much contact mountain congregations, even those along the railroad, had with the social gospel. No records exist either way, but given the silence of the Baltimore Conference, it seems likely that the social gospel had minimal impact on the mountain counties or the conference as a whole, even if the mission work of the women produced notable spiritual and physical results. On the other hand, fundamentalism seemed to gain little traction in the region either. Thus, a moderate theological conservatism prevailed along with an equally moderate social conservatism.

\section{Presbyterians}

Presbyterians arguably made the fewest theoretical contributions to the social gospel of the Big Three Protestant denominations. However, Presbyterian theologians, scholars, and clergy significantly augmented social Christianity in their own ways, at times building upon the work of other denominations and at other times forging their own path. Furthermore, the more hierarchical denominational structure created some early theological skirmishes that presaged the

\footnotetext{
51"Report on Temperance and Social Service," Minutes of the Baltimore Conference, Methodist Episcopal Church, South, 1927, 82. The social gospel did affect the Baltimore Conference through the women's home missionary movement. In 1904, women in the area formed a home missionary society, which became the Women's Home Missionary Council in 1910. Most of their work took place in Maryland and Virginia, but they eventually began laboring in the West Virginia coal fields, although not in the highlands. In 1918, a student movement formed, calling itself "North American Students Mobilizing for Christian World Democracy." Apparently, no students from West Virginia joined the group. However, the platform, as well as the name itself, indicated a strong indebtedness to the social gospel. They sought to discuss and study the "present world situation in relation to the Kingdom of God" and to apply the principles thereof to the "interracial and social life of North America." See "North American Students Mobilizing for Christian World Democracy," Eighth Annual Report of the Women's Missionary Council (Nashville: Publishing House for the Methodist Episcopal Church, South, 1918), 132.
} 
battles of the 1910s and 1920s. Among the Presbyterians, most of these occurred in the North. ${ }^{52}$

However, Southern Presbyterians, despite devout allegiance to Westminster orthodoxy, also grappled with doctrine before the turn of the twentieth century. Oddly enough, however, Darwinian evolution "received far more attention in the Southern Church than it did in the North." ${ }^{53}$ In the 1880s, conservatives led by Robert Lewis Dabney mounted an effort to silence James Woodrow, professor of science and religion at the Presbyterian Seminary in Columbia, South Carolina, who believed the Darwinian model of evolution could legitimately explain the biblical account of Creation and did not contradict anything in the Bible. Woodrow maintained firm allegiance to the Westminster Confession, believing it did not address the issue. In 1886, the General Assembly overwhelmingly recommended Woodrow's dismissal from his teaching position, although he remained an ordained minister. Two years later, the General Assembly passed doctrinal deliverances affirming the historicity of Adam and a literal interpretation of

\footnotetext{
${ }^{52}$ Northern Presbyterians did not have a presence in the mountain counties studied here and thus are not a major part of this study. However, that denomination certainly merits brief mention in this chapter. Some of the earliest doctrinal battles occurred in the Presbyterian Church of the United States of America. Northern Presbyterians helped codify the "fundamentals" with the Doctrinal Deliverance of 1910. The General Assembly adopted a fivepoint statement crafted by the Committee on Bills and Overtures which identified those doctrines which the denomination held as "essential and necessary." That list included the inspiration and inerrancy of the Bible, the virgin birth of Christ, the substitutionary atonement of Christ, the bodily resurrection of Christ, and the veracity of miracles. All ministerial candidates were required to affirm those beliefs. Minutes of the General Assembly, 1910, 272-273. For more on this subject, see Gary Dorrien, The Making of Liberal Theology: Imagining Progressive Religion, 1805-1900 (Louisville: Westminster John Knox, 2001), 275-279, 361-365; Lefferts A. Loetscher, A Brief History of the Presbyterians, $3^{\text {rd }}$ ed. (Philadelphia: The Westminster Press, 1978), 129-136; Milton J. Coalter, John M. Mulder, and Louis B. Weeks, eds, The Diversity of Discipleship: The Presbyterians and Twentieth-Century Christian Witness (Louisville: Westminster/John Knox Press, 1991); Milton J. Coalter, John M. Mulder, and Louis B. Weeks, eds., The Reforming Tradition: Presbyterians and Mainstream Protestantism (Louisville: Westminster John Knox Press, 1992); Bradley J. Longfield, The Presbyterian Controversy: Fundamentalists, Modernists, and Moderates (New York: Oxford, 1991); James H. Smylie, A Brief History of the Presbyterians (Louisville: Geneva Press, 1996); J. Michael Utzinger, Yet Saints Their Watch Are Keeping: Fundamentalists, Modernists, and the Development of an Evangelical Ecclesiology, 1887-1937 (Macon: Mercer University Press, 2004).

${ }^{53}$ Lefferts A. Loetscher, A Brief History of the Presbyterians, $3^{\text {rd }}$ ed. (Philadelphia, Westminster Press, 1978), 120.
} 
Genesis, which clearly stated their position that evolution and the biblical account of creation were incompatible. $^{54}$

This stance positioned Southern Presbyterians firmly alongside the rest of Southern Protestantism during the period. It also demonstrated a type of Presbyterian solidarity, as members North and South fought for the "old time religion." Unlike the North, where major theological battles raged on and off for nearly fifty years, the Southern doctrinal front remained relatively quiet for roughly forty years after the Woodrow trial. The PCUS was certainly aware of the theological controversy in the North but made no mention of it. While Southerners believed in the "five fundamentals," there was no official Southern list of fundamentals. Those who became known as fundamentalists remained in control of the PCUS until the Great Depression. ${ }^{55}$ Denominational newspapers, the publications of major theologians, and General Assembly records indicated a united front in such matters.

Unfortunately, few newspapers from the Southern branch of the Presbyterianism survive from this period. Those that do, however, show a commitment to what became known as the "five fundamentals" (which did vary in number at different times). Although that doctrinal stance was popularized as such by the PCUSA in 1910, conservatives across the denomination long believed them to be central to the Christian faith. The few extant periodicals, all dated before the turn of the century, reveal this conviction. An 1885 article from the Central Presbyteri-

${ }^{54}$ Sydney E. Ahlstrom, A Religious History of the American People, vol. 2 (New York: Image Books, 1975), 183; Loetscher, 120, 121; Thompson, Presbyterians in the South, Vol. 2, 458-490.

${ }^{55}$ Milton J. Coalter, John M. Mulder, and Louis B. Weeks, eds., The Reforming Tradition: Presbyterians and Mainstream Protestantism (Louisville: Westminster John Knox Press, 1992), 126; Thompson, Presbyterians in the South, Vol. 3, 324. This certainly does not mean that every pastor, teacher, and church-goer fully embraced and accepted fundamentalism. Liberals, moderates, and non-fundamentalist conservatives also belonged to the PCUS. Between the 1890s and 1920s, several pastors did question the official denominational theology. However, none of these men created the controversy that Woodrow had and no other incident reached the General Assembly. Serious and sustained challenges to fundamentalism really did not begin to appear on the radar until the second decade of the twentieth century and the General Assembly did not address the issue again until 1924. See Thompson,

Presbyterians in the South, Vol. 2, 442; Vol. 3, 302-307. 
an, which became a recommended publication within the bounds of the Synod of Virginia, is particularly illustrative. $^{56}$

In a column entitled "Story of the Greek New Testament," an unnamed author made the case for the inspiration of the Bible, or more specifically the New Testament, in the original language only. At the same time, the author made the case that some form of biblical criticism could be used in defense of traditional conceptions of inspiration and inerrancy. Only the original texts were inspired because the Holy Spirit worked only through those original authors, not through any subsequent scribe or translator. Addressing adherents of some kind of inspiration of concepts or truths, the author pointed out that all ideas, no matter how abstract, must be expressed by words. Thus, the truth of the Bible is expressed in the very text of the Bible, and denying the inspiration of its very words called into question the inspiration of the ideas they conveyed. $^{57}$

All copies and translations, in whatever language, contained some error. However, through textual criticism, biblical scholars determined which Greek text was the closest to the original. Textual criticism had also demonstrated the close agreement between all available Greek texts. The traditional doctrines of the faith are found in all of them, even if the texts do not all agree in every jot and tittle. "[I]nstead of making changes in the Greek text, scholarly criticism will tend to give it permanence," the author asserted. Unlike higher criticism, which sought to undermine the text, textual criticism sought to uncover the original documents. Thus,

\footnotetext{
${ }^{56}$ Minutes of the Synod of Virginia, 1896, 463.

57" Story of the Greek New Testament," Central Presbyterian (Richmond, VA), Aug. 26, 1885. A letter to the paper in 1887 demonstrated why reunion between Northern and Southern Presbyterians proved difficult, despite significant doctrinal agreement and a willingness on both sides to cooperate with other Reformed and Presbyterian bodies. After nearly thirty years, neither side could quite get over the Civil War. Both remembered the other's attacks on beloved clergy and decidedly non-central theology positions, such as views on slavery and secession, if such topics could even be considered theological. "Reply to the Open Letter," Central Presbyterian (Richmond, VA), Sept., 7, 1887. Those hard feelings lingered into the twentieth century. By the turn of the century, however, Southerners also hesitated to discuss union due to increased liberal activity within the Northern denomination.
} 
because of careful scholarship, the average reader could rest assured that they read the true Word of God. ${ }^{58}$

Unfortunately, the availability of PCUS newspapers drops off abruptly in the early 1890s. After that time, it is difficult to get a feel for Southern Presbyterian attitudes that existed alongside the official pronouncements of the General Assembly and the work of denominational theologians. However, the limited newspaper evidence, when coupled with material from theologians and the General Assembly, paints a clear picture about the nature and development of Southern Presbyterian theology.

The majority of the literature on fundamentalism focuses on Northern denominations. ${ }^{59}$ While the 1885 newspaper article on inspiration and inerrancy clearly demonstrated Southern awareness and approval of Northern theological positions, it by no means indicated Southern reliance on the North for theology. At least until the turn of the twentieth century, and in many ways through the 1920s, a basic theological unity spanned the several branches of American Presbyterianism. Much of this, of course, stemmed from the fact the major split in the church occurred primarily for political and not theological reasons. Thus, in many important ways,

\footnotetext{
58“"Story of the Greek New Testament." In short, higher criticism attempts to apply scientific methodology in studying the Scriptures in order to determine authorship, sources, and how the context in which a text was written might have influenced the author and the content of the document. By contrast, lower criticism, also called textual criticism, deals solely with the text itself. Textual critics examine variant readings of a particular text in an effort to determine which one best preserves the original autograph. For more on both higher and lower criticism, see the respective entries in Walter A. Elwell, ed., Evangelical Dictionary of Theology $2^{\text {nd }}$ ed. (Grand Rapids: Baker Academic, 2001), 554-556, 1178-1180.

${ }^{59}$ Mark A. Noll, The Scandal of the Evangelical Mind (Grand Rapids: Eerdmans, 1994), 114-126. For more on the theological development of fundamentalism, see Fisher Humphreys and Philip Wise, Fundamentalism (Macon: Smith \& Helwys, 2004). For a detailed examination of how and why fundamentalism arose in the North, see George M. Marsden, Fundamentalism and American Culture (New York: Oxford University Press, 2006) and Ernest Sandeen, The Roots of Fundamentalism: British and American Millenarianism, 1800-1930 (Chicago: The University of Chicago Press, 1970). Treatments on mid-twentieth century fundamentalism give more attention to Southern Protestantism, but still place Northern Christians as the driving forces behind the movement. For more on that topic, see works such as George M. Marsden, Reforming Fundamentalism: Fuller Seminary and the New Evangelicalism (Grand Rapids: Eerdmans, 1987) and Joel A. Carpenter, Revive Us Again: The Reawakening of American Fundamentalism (New York: Oxford University Press, 1997).
} 
theological unity between North and South was a result of shared Presbyterian roots, rather than one section borrowing from another. The theological conservatism and later fundamentalism of the South certainly did not result from Northern and urban theology being taken out of context.

Despite a common heritage and the greater prominence of PCUSA theologians, the southern wing produced its own theologians who made contributions to church life and thought. These men contributed to the making of a Southern fundamentalism much as their Northern counterparts constructed Northern fundamentalism. Furthermore, Southern doctrinal history suggests the conservative position was not a reactionary innovation occasioned by the rising tide of liberalism.

Perhaps the best known Southern Presbyterian preachers were from the Civil War era men such as James Henley Thornwell, Benjamin Morgan Palmer, and Robert Lewis Dabney although their pro-slavery stances and support of the Confederacy often overshadow their particularly theological contributions. Thornwell died in 1862, but he articulated a view of "plenary verbal inspiration resulting in an infallible Scripture." ${ }^{60}$ This meant that the very words of the Bible were inspired by God, and those were without error or mistake.

Palmer and Dabney (both of whom assumed the mantle of denominational theologian after Thornwell's death, training before the war and before the advent of Darwinism and the widespread use of higher criticism in the United States) echoed these views. Much less well-known second generation thinkers such as Thomas E. Peck, William Swain Plumer, and John Lafayette Girardeau also taught and preached a traditional American Presbyterian understanding of the Bible. $^{61}$ This understanding held sway well into the twentieth century and grew organically from

\footnotetext{
${ }^{60}$ Morton H. Smith, Studies in Southern Presbyterian Theology (Phillipsburg, NJ: Presbyterian and Reformed Publishing Company, 1962), 127-132.

${ }^{61}$ Smith, 228-254.
} 
within the PCUS. While generally not known outside the denomination, those men and the Southern Presbyterian Church as a whole remained committed to what had become fundamentalist orthodoxy through the first third of the twentieth century. ${ }^{62}$

What major battles the PCUS did engage in through the 1920s took place outside the denomination in the ecumenical arena. While both Northern and Southern Presbyterians frequently balked at reunion during this time, both remained open to some form of cooperation among all churches in the Reformed Tradition (this would include smaller Presbyterian groups such as the Cumberland Presbyterian Church as well as the various branches of what had been the Dutch Reformed Church) and took steps toward such a confederation in 1905. Such an organization would in no way hinder the autonomy of its constituents; rather, it would allow for greater cooperation and fraternization among them in spreading the gospel. ${ }^{63}$

This attitude led Northern and Southern Presbyterians to become charter members of the Federal Council of Churches in 1908. The decision by Southern Presbyterians to join the FCC reflected denominational efforts to take a well-rounded approach to ecclesiastical relations as well as the less well-defined association between the theological and political spectrums. They remained committed to a literal interpretation of the Bible and the rejection of the liberal theological underpinnings of the social gospel, but that did not necessarily mean they rejected all social concern or action whatsoever. While Southern Presbyterians and their social gospel brethren

\footnotetext{
${ }^{62}$ For more on the home-grown nature of Southern Presbyterian fundamentalism, see Sean Michael Lucas, “ 'Our Church Will Be on Trial': W.M. McPheeters and the Beginnings of Conservative Dissent in the Presbyterian Church in the United States," The Journal of Presbyterian History Vol. 84, No. 1 (Spring/Summer 2006), 1, 2, 54, 55; and Thompson, Presbyterianism in the South, Vol. 2, 446-465; Vol. 3, 302-310, 323-325.

${ }^{63}$ Minutes of the General Assembly of the Presbyterian Church in the United States (Richmond: Presbyterian Committee on Publication, 1905), 109-111.
} 
might not always have seen eye-to-eye on reform, the former body by no means rejected all of the latter's ideas on improving society.

As Presbyterian historian Robert Schneider notes, from the outset, misunderstandings existed about the purpose of the Council. It is easy to look back now and see the overwhelming social gospel influence from the beginning. At the time, some of the more conservative groups involved, including the PCUS, believed the ecumenical body's work would center on traditional nineteenth century Protestant concerns and methods, which included evangelism, Sabbath observance and Sunday Schools, temperance reform, and family issues. Due to the doctrine of the spirituality of the church, the Southern Presbyterian church usually had been reluctant to advocate for political action in these areas, but to them, that seemed to be precisely the point of the FCC. Churches united would not have to rely on the state. ${ }^{64}$

It quickly became clear, however, that the FCC would be a vehicle for the social gospel. Labor, business, race, urban services, and even the structure of federal and state governments merited attention and needed Christianization. ${ }^{65}$ The social statement issued by the Southern Presbyterian church in 1914, as well as by the Northern and United Presbyterian churches, highlighted the differences between the conservative aims of several constituent denominations and the more liberal aspirations of the FCC. It was also illustrative of some aspects of the Great Reversal and the evolution of the relationship between social action and theology.

The United Declaration on Christian Faith and Social Service, adopted by both Northern and Southern Presbyterians in 1914, became the first statement on social activism by either wing of the church. The PCUS, the PCUSA, the United Presbyterian Church, and the Associated Re-

\footnotetext{
${ }^{64}$ Robert A. Schneider, "The Federal Council of Churches and American Presbyterians, 1900-1950," The Journal of Presbyterian History Vol. 84, No. 2 (Fall/Winter 2006), 111-113.

${ }^{65}$ Schneider, 113.
} 
formed Presbyterian church cooperated to produce the document. Despite some disagreement among Presbyterians, especially in the South, and the FCC, other points of agreement prevailed regarding social teaching. The United Declaration called for a fair wage for labor and condemned child labor, degrading working conditions for women, the unjust and unequal distribution of wealth, and the exploitation of labor. It called for all people in all areas of life to employ "the Christian principles of Love, Justice, and Truth in all their social relations, economic, industrial, or political." 66

The FCC social creed contained the same ideas, but the two reports differed significantly on how to implement these teachings. The Presbyterian document also upheld the importance of social involvement while firmly subordinating it to the duty of the church to labor for the salvation of souls. Against the social gospel concept of social salvation, the phrase "Christian Faith" meant "the teachings of the Holy Scriptures, the essential doctrines of which are held in common by all Evangelical Churches and are embodied in the ecumenical creeds of Christendom." "Social Service" followed from the teachings of Scripture and was "evidence of a lively faith, and at best cannot merit pardon of sin or eternal life." ${ }^{\circ 7}$

In a firm but non-combative tone, Presbyterians also took issue with the means the FCC used to accomplish its goals. Both church and state were ordained by God, but God specifically gave them distinct functions. The church was required to better the spiritual lives and physical lives of men and women. However, the church's power was "spiritual, ministerial and declarative" and it was "to inculcate and apply those principles" in its own way and by its own means. ${ }^{68}$

\footnotetext{
${ }^{66}$ "Report on the Ad-Interim Committee on Christian Faith and Social Service," Minutes of the General Assembly of the Presbyterian Church in the United States (Richmond: Presbyterian Committee on Publication, 1904), 162.

67“The United Declaration...," 161.

${ }^{68 ،}$ "The United Declaration...," 162.
} 
The concept of the spirituality of the church, then, did not mean the church simply ignored the goings-on in the world. Rather, the church prophetically confronted injustice and evil with and on its own God-given power, and did not, nor should not, become involved in politics nor rely on chiefly political means to achieve righteous ends. The denomination as a whole continued to address reform concerns, albeit now in greater numbers, as it always had, even as the FCC and social gospelers called for more progressive reform. Thus, in an important sense for the PCUS, still firmly under conservative and fundamentalist control in the 1920s, the Great Reversal never really occurred.

The overtly political and at times seemingly radical nature of the Federal Council of Churches did not sit well with many Southern Presbyterians. The General Assembly received frequent calls to withdraw. On a few occasions in the earliest years it did, only to re-enter shortly thereafter. At times, the General Assembly also unsuccessfully petitioned the FCC to change its position on various issues. ${ }^{69}$ Despite this contentious relationship, conservative Southerners persevered in the ecumenical movement until 1931, when a combination of theological liberalism and social activism proved intolerable. ${ }^{70}$

State and local denominational groups displayed this continued faithfulness to classic dogma. Until 1914, PCUS churches in West Virginia belonged to the Synod of Virginia.

\footnotetext{
${ }^{69}$ Smylie, 108; Minutes of the General Assembly of the Presbyterian Church in the United States (Richmond: Presbyterian Committee on Publication, 1919), 55. For more on the Federal Council of Churches, see, among others, John A. Hutchinson, We Are Not Divided: A Critical and Historical Study of The Federal Council of the Churches of Christ in America (New York: Round Table Press, 1941) and C. Gregg Singer, The Unholy Alliance (New Rochelle, NY: Arlington House Publishing, 1975). For more on the sometimes rocky relationship between the PCUS and FCC, see Milton J. Coalter, John M. Mulder, Louis B. Weeks, eds., The Diversity of Discipleship: The Presbyterians and Twentieth-Century Christian Witness (Louisville: Westminster John Knox, 1991), 154, 155; Schneider, 109.

${ }^{70}$ The Diversity of Discipleship, 155. See also Schneider, 119. On the eve of American involvement in World War II, the Southern Presbyterian church once again rejoined the Federal of Council of Churches, believing the war necessitated a united Christian front. It also became an active and supportive participant in the reorganization of the group, in 1950, as the National Council of Churches.
} 
Through the 1920s, synodical records reflect a deep commitment to traditional Presbyterian concepts of the spirituality of the church and to nineteenth century-style reform work. The Synod had committees on Sabbath and temperance reform, as well as evangelism, but said nothing about other social work. There is no mention of the United Declaration on Christian Faith and Social Service or the Federal Council of Churches.

A resolution passed in 1910, however, sheds some light on how West Virginia and Virginia Presbyterians thought about ecumenism and interdenominational cooperation. The motion expressed no problem with working with other churches. The church was the body of Christ, and the Master commanded unity. But, the Synod argued, the unity was not external but internal - "a spiritual unity, of love and sympathy and of effort to win the world to Christ.",

This spiritual unity could be achieved, despite widely differing doctrinal beliefs, by focusing on those things which all the churches held in common. As Presbyterians understood it, the great commonality was "the salvation of men." Thus, they could cooperate with all groups desiring to do this, but doctrine was still very important, and any plan of cooperation that infringed upon denominational beliefs would be unacceptable. ${ }^{72}$

The newly formed Synod of West Virginia appeared to follow in the footsteps of its mother synod. Into the 1920s, save for infrequent references to temperance and the Sabbath, the records contained absolutely no mention of other social issues. They made just passing reference to doctrine, although those mentions clearly pertained to the fundamentals and the battle against liberalism. In 1914, the first year of the Synod of West Virginia, the Northern Presbyterians in West Virginia extended a cordial greeting to their co-religionists. The Southern synod responded

\footnotetext{
${ }^{71}$ Minutes of the Synod of Virginia, 1910, 52.

${ }^{72}$ Minutes of the Synod of Virginia, 52.
} 
by saluting the Northern synod's commitment "to the atonement for sin, by the death of Christ, $\ldots$ in the vicarious suffering and death, resurrection and ascension" of Jesus. The body of Christ needed such a faithful witness, especially in "view of the loose views which are now so prevalent, as to the divine origin of the human race, of the birth of our Saviour, the Lord Jesus Christ, and the skepticism abroad in the land.,73

Not surprisingly, conservatism remained firmly entrenched in the three presbyteries which comprised the Synod of West Virginia; modern social concern did not register with the presbyteries of Greenbrier, Winchester, and Tygart's Valley. The Greenbrier and Winchester presbyteries, in addition to the Lexington Presbytery from which the Tygart's Valley Presbytery was formed in 1911, maintained a continued interest in temperance and the Sabbath. Despite the rapid industrialization in the mountains and the solid growth of the PCUS in the mountain counties, the presbyteries expressed no desire, official or otherwise, to deviate from the spirituality of the church. It is possible they saw their existing programs of evangelism, reform, and Sunday School as fulfilling the spirit of the PCUS's statement on social service, but that is merely conjecture.

Under the Presbyterian form of government, the proclamations of the General Assembly possessed no binding authority on constituent synods, presbyteries, and churches. Without a clear resolution on the topic, it is impossible to discern exactly what the various West Virginia presbyteries thought of the new social reform movements. At best, when put into context, the argument from silence indicates traditional understandings of Presbyterian theology and polity in matters of social and political action prevailed in the mountains. It suggests that mountain Presbyterians gave no quarter to the social gospel.

\footnotetext{
${ }^{73}$ Minutes of Synod of West Virginia, 1915, 11.
} 
One notable incident, however, does provide some evidence that the mountain Presbyterians leaned toward fundamentalism. Some churches in the mountains had stood for generations before industrialization. Others sprang up as the railroad rumbled through. Churches old and new rallied around the old ways and did their best to ensure that theological liberalism would have as little success in West Virginia as did the social gospel.

In 1915, a Reverend John McKenzie came under review by the Presbytery of Tygart's Valley. The presbytery's inquiry focused primarily on the veracity of miracles and the inspiration of Scripture. The report given for the official minutes excluded the actual questions, but did include a detailed summary of Rev. McKenzie's reply. The pastor affirmed his belief in the "plenary inspiration of Scriptures - that the Bible is fully inspired in all its parts." He admitted that he remained unsure about whether all individual words were equally inspired, but he still taught the inspiration "of the whole Bible and each of its parts." "74

In holding to Mosaic authorship of Genesis, he rejected a basic claim of higher criticism. McKenzie equivocated slightly by saying that he thought Moses recorded the events he truly believed to have happened, such as the creation of Eve from Adam. However, he seemed to satisfy his inquisitors by claiming he could "only take the account (of Eve's creation) as it stands as the record of an actual occurrence." He went on to say he fully believed the historicity of the events of Jonah, including the ingestion of Jonah by the whale. ${ }^{75}$

The committee judged McKenzie's position on miracles by standard Southern Presbyterian orthodoxy. At one point during the interview, the moderator appealed to the authority of R.L.

\footnotetext{
74،“Summary of Reaffirmation, Etc., of Rev. John McKenzie," Minutes of the Presbytery of Tygart's Valley, 1915, 103.

75“"Summary of Reaffirmation," 103. Note that this is fifteen years before Clarence Darrow posed the same question to William Jennings Bryan at the famous Scopes Monkey Trial.
} 
Dabney's definition of the term. McKenzie agreed with Dabney. Miracles resulted from God's immediate action in the natural realm, without the use of secondary causes. The testimony closed with a final affirmation of miracles, the infallibility of the Bible, the deity of Christ, and the messianic nature of Psalms 22 and 110 and Isaiah $53{ }^{76}$

While admittedly a lone occurrence, it is telling. The leaders of the churches in the mountains of West Virginia took doctrine seriously and upheld the PCUS standard. The fact that the presbyteries and the Synod were otherwise silent on matters of doctrine suggests a theological uniformity among West Virginia Presbyterians. The reaffirmation of Rev. McKenzie demonstrated a willingness by the churches to interrogate doctrinally-suspect clergy.

Furthermore, this incident is perhaps the best reflection of the conservatism of individual congregations. While records are by no means complete, those that do exist from local Sessions show no sign of struggles over doctrine, whether strictly theological or practical; no other churches sent preachers to be reaffirmed. West Virginia Presbyterian churches focused primarily on ensuring that believing communities functioned in an orderly fashion according to the Presbyterian understanding of Scripture, that members received appropriate spiritual nourishment, and that the gospel was preached.

Baptists

Among the Baptists, Methodists, and Presbyterians, Baptists, in particular Northern Baptists, made the most substantial and earliest contributions to the social gospel. ${ }^{77}$ Walter Rausch-

\footnotetext{
76، Summary of Reaffirmation, ...," 104. Unfortunately, no other information about the McKenzie case exists. Most likely he served as pastor in one of the churches within the bounds of the Tygart's Valley presbytery, although records for local churches are not detailed enough to determine exactly where McKenzie labored. His congregation probably expressed concern over his beliefs and appealed to the regional hierarchy. The context of the statement indicated the presbytery accepted McKenzie's beliefs, and the synodical records show no evidence of the case going any higher up the chain of authority.

${ }^{77}$ Southern Baptists, with no churches within these counties during this period, are not a major part of this study. Nevertheless, the Southern Baptist understanding of the social aspect of Christianity should be noted, both for its
} 
enbusch, Samuel Zane Batten, William Newton Clarke, and Shailer Matthews, among others, led the way in developing this brand of theological liberalism in America. Along with Rauschenbusch and many others, Batten, a Philadelphia pastor, and Clarke, a theologian and professor at Hamilton Theological Seminary, formed an organization which became known as the Brotherhood of the Kingdom. This group, which eventually expanded to include both women and nonBaptists, published numerous pamphlets advocating a "now/not yet" view of the kingdom in which the kingdom was in some sense already a reality on earth while some aspects would only be fully realized in the future. The Brotherhood constituted one of many outgrowths of the social gospel in the Northern Baptist churches.

The ideas of Rauschenbusch and others, along with rapidly-changing conditions across America, led to the creation of a unified Baptist denomination in the North. In 1907, the various Baptist societies in the North, including the American Baptist Publication Society, the American Baptist Foreign Mission Society, and the American Baptist Home Mission Board, united in a single entity: the Northern Baptist Convention. Each society would now be a board under the auspices of that Convention. The minutes from the first session indicate that modern conditions and "the revolutionary change in social organization" required greater cooperation among Northern Baptists. Like governments and business, Baptists attempted to use size to their advantage.

own merits and its usefulness in comparing and contrasting denominational activity. For more on this subject, see Keith Harper, The Quality of Mercy: Southern Baptists and Social Christianity, 1890-1920 (Tuscaloosa: The University of Alabama Press, 1996), 1-14; Daniel W. Stowell, Rebuilding Zion: The Religious Reconstruction of the South, 1863-1877 (New York: Oxford, 1998); Rufus B. Spain, At Ease in Zion: A Social History of Southern Baptists, $1865-1900$ (Tuscaloosa: The University of Alabama Press, 2003); Beth Barton Schweiger, The Gospel Working Up: Progress and the Pulpit in Nineteenth-Century Virginia (New York: Oxford, 2000); Michael E. Williams, Sr., Isaac Taylor Tichenor: The Creation of the Baptist New South (Tuscaloosa: The University of Alabama Press, 2005); Wayne Flint, "Dissent in Zion: Alabama Baptists and Social Issues, 1900-1914," Journal of Southern History 35 (Winter 1969) : 532-542; Wayne Flint, "Southern Baptists and Reform, 1890-1920," Baptist History and Heritage 7 (October 1972) : 211-222 (among several others by Flint); John W. Storey, Texas Baptist Leadership and Social Christianity, 1900-1980 (College Station, TX: Texas A\&M Press, 1986); and Barry Hankins, Uneasy in Babylon: Southern Baptist Conservatives and American Culture (Tuscaloosa: The University of Alabama Press, 2002). 
State conventions and associations received automatic membership in the national Convention because of membership in the various national societies which united in the Northern Baptist Convention. ${ }^{78}$

Technically, the Northern Baptists now had a denominational structure equal to that of the Southern Baptists. As Baptist historian Leon McBeth noted, official organizational centralization did not necessarily give more power to the national body nor did it require constituent associations and churches to surrender any autonomy. "The Northern Baptist churches, lacking any sustained tradition of denominational cooperation, failed to rally thoroughly around the new convention, and the societies, though now called boards, behaved much as before," he observes. ${ }^{79}$ In fact, in keeping with spirit of the age and Baptist heritage, the Convention explicitly endorsed ecclesiastical democracy and declared it would "never control the Baptist churches. ${ }^{\Perp 80}$

The next year, the body set up committees to outline the relationship of the church to social issues, including labor and industry. Strong and overt social gospel influences were most obvious in the committees and reports pertaining to how the church related to society, whether regarding labor, education, or other public matters. When formulating a denominational position on labor-capital relations and the nature of modern society, Convention delegates argued that "The kingdom of God, in the Christian concept, may mean much more than a human society on earth, but it is certain that it can never mean less. The program of the kingdom includes daily

\footnotetext{
${ }^{78}$ Minutes of the American Baptist Publication Society, (New York: ABPS, 1909), 78.

${ }^{79} \mathrm{McBeth}, 566$.

80،“The Convention Minutes," Annual of the Northern Baptist Convention, 1908, 27.
} 
bread for all; it demands the removal of the things that may become temptations; and it implies the deliverance of the life from all evil.",81

The committee commissioned Shailer Matthews to write a series of teachings on "The Social Gospel" for use in churches across the country. The group adopted a modified platform on labor and industry, which it took from the Committee on the Church and Modern Industry of the Federal Council of Churches, of which the NBC was a charter member, in 1908. The statement called for labor union recognition, safer working conditions, higher wages, abolition of child labor, and regulation of women's labor. While many cast social gospelers as political radicals, in general, the statement was quite moderate. Capital and labor should unite in brotherhood, but there were no attacks on private property or calls for labor to have a greater input in management decisions beyond wages and hours. ${ }^{82}$

By 1911, the various committees on social issues combined into the Social Service Commission. Such social gospel and liberal stalwarts as Rauschenbusch, Batten, and Matthews consistently served on the commission, which dealt with everything from labor to divorce to worldly amusements, drafting detailed position statements on each topic. ${ }^{83}$ Each time, in the end, the Kingdom of God was both the example to follow and the goal to reach. As the commission stated in 1915, "To seek the kingdom of God means much more than to seek the salvation of one's soul or even the up-building of the church. To seek the kingdom of God means to seek the salvation of the family, the redemption of the State, and the Christianization of society." 84

\footnotetext{
81،"The Church and Labor and Industry," Annual of the Northern Baptist Convention, 1909, 133. 
The formation of the Northern Baptist Convention gave liberals, modernists, and social gospelers power and influence far greater than their numerical strength among Northern Baptists. The liberal base consisted primarily of younger scholars and urban pastors, although conservatives were still in the majority. Many older professors were conservative, and most local pastors still taught traditional positions on Scripture and the person and work of Christ. Brackney notes that the Convention did not create this diversity, but greater centralization did allow it to become a problem in ways that might not have developed had the societies remained independent. ${ }^{85}$

In the first few years of Convention proceedings, conservatives seemed to hold little power and seemed unable to muster their forces. They voiced no real opposition to the pronouncements of the Social Service Commission, even though that body was a major platform for social gospel ideas. Eventually fundamentalists did respond, however, and their concerns and actions in the NBC demonstrated important aspects of the "Great Reversal." Over the course of the 1910s, fundamentalists traveled the country, warning congregations of the dangers of heresy and rallying support. They quickly coalesced into a major organized force in the Convention.

Education, missions, and publications constituted three early doctrinal battlegrounds in the Northern Baptist Convention. The conflicts began in the mid-1910s but extended well into the 1920s. Conservatives mounted a multi-pronged assault against theological liberalism. First, they tried to root out "suspect" doctrine in denominational colleges and universities. Second, they called for a purge of theologically-liberal missionaries. Finally, they urged the Convention to sell its official weekly publication, The Baptist. ${ }^{86}$

\footnotetext{
${ }^{85}$ William H. Brackney, The Baptists (Westport, CT: Praeger, 1994), 29.

${ }^{86} \mathrm{McBeth}, 572-576$.
} 
For all their efforts, fundamentalists failed to achieve victory on any of these fronts. Nevertheless, they did make some gains in the Convention. In 1920, they held a pre-convention meeting in Buffalo at which they called for an investigatory commission to probe the doctrinal positions of the Baptist colleges. They also articulated several theological points deemed "fundamental Baptist truths" to which the schools, faculties, and trustees should adhere and which they should promote. These views included "the inspiration of the Word of God, the Deity of Christ, the atonement, the resurrection, the return of the Lord, the spiritual nature of the church, the necessity for a regenerated, baptized church membership, the unchanged nature of the obligation of the ordinances of baptism and the Lord's Supper, and the imperative responsibility of carrying out the great commission." 87

The group dominated the Buffalo meeting. It forced the NBC to withdraw from the increasingly unpopular Interchurch Movement, an ecumenical effort at domestic and international cooperation which included thirty denominations. It also formed the Fundamentalist Fellowship and made plans to capture the entire Convention. While it seemed that some segments of the Convention were more moderate and conciliatory than fundamentalists wished, conservatives still constituted a powerful force within the body. However, the Convention itself had no statement of faith, which made it hard to prove heresy. A confession would make it easier to uphold orthodoxy. Yet the fundamentalists were still Baptists. Thus, in 1922 when they offered a resolution concerning the New Hampshire Confession (see Chapter 6) with a premillennial interpretation of the final article, it did not call for the Convention itself to adopt any official doctrinal standard. Rather, the Convention was

\footnotetext{
${ }^{87}$ "Resolutions of the Pre-Convention Conference on Fundamentals," Annual of the Northern Baptist Convention, 1920, 48. The Great Commission refers to that final set of instructions Jesus gave to his disciples to make disciples of all nations. Versions of these last words appear at the end of the Gospels of Matthew, Mark, and Luke.
} 
simply to recommend the New Hampshire Confession "to all such local Baptist churches within our bounds as feel the need of a clear and competent confession." ${ }^{" 88}$ Thus, they would preserve traditional Baptist theology and polity.

Opponents offered a well-crafted counter-resolution which stated that "the Northern Baptist Convention affirms that the New Testament is the all-sufficient ground of our faith and practice and we need no other statement." ${ }^{\prime 89}$ This second proposal passed two to one. The conservative majority of the Convention found it difficult to vote against the Bible itself. At the same time, liberals supported it because it specified no particular interpretation of the sacred text. Marsden argued that the defeat of the New Hampshire Confession irreparably harmed the fundamentalist movement in the Northern Baptist Convention. After a period of strength and unity, the far-right wing splintered into two groups. The more moderate fundamentalists increasingly aligned with the conservatives and became less militant; the more extreme fundamentalists formed the Baptist Bible Union, along with Canadian and Southern Baptists, splitting from the NBC in 1932 and forming the General Association of Regular Baptist Churches the next year. ${ }^{90}$

Local church records make no mention of these theological debates and the conflict and division they produced. After the brief formative periods of the several churches, in which they stated doctrinal positions and drafted church covenants, church records are quite mundane, dealing exclusively with the business and life of the local church. Even local association records seldom, if ever, address doctrinal concerns at the national level. Through the state General

\footnotetext{
88“"Resolution to Adopt the New Hampshire Confession," Annual of the Northern Baptist Convention, 1922, 129, 130.

89،"Substitute Resolution,” 133.

${ }^{90}$ Marsden, 171, 172; McBeth, 577, 578. The less militant fundamentalists remained in the NBC in 1947, when they left to organize the Conservative Baptist Association of America.
} 
Association and the state Baptist paper, The Baptist Banner, local churches continued to be connected to and aware of national Baptist life and new trends and developments. Along with the minutes of the General Association, The Baptist Banner showed that West Virginia Baptists remained faithful to their theological roots amidst significant shifts in Northern Baptist thought. Over the course of the 1910s and the early 1920s, West Virginia Baptists, already conservative, moved firmly (but briefly) into the moderate wing of the fundamentalist faction, joining in calls for action at the national level while nevertheless having few to worries about doctrinal dissent at home.

Amid lingering challenges from anti-mission Baptists and mounting challenges from theological liberals, the General Association sought to assert both its relevance to West Virginians and its allegiance to a Baptist understanding of the faith. Summarizing the beliefs of West Virginia Baptists, the Reverend T.H. Tiffany, at the time pastor of the Elkins congregation, wrote for the General Association:

We have held to the sovereignty of God; the direct access of all souls to God; equal privileges of all believers in the churches; the individual responsibility of every believer; the complete separation of church and state; and regenerated church membership baptized with a believer's baptism upon a personal profession of faith in Christ. ${ }^{91}$

In encapsulating many of the core assertions of the various statements of faith adopted by Baptists throughout West Virginia, including the younger churches in the mountains, this short paragraph reveals a crucial fact about how these Baptists viewed their faith. At its center, Christianity was a religion that focused on rectifying the relationship between individuals and God. The restoration of this faith brought people into communion with God and with fellow

\footnotetext{
${ }^{91}$ Hank, et. al., 74.
} 
believers. Thus, any emphasis on community and solidarity was a function of the initial individualism of the one-on-one encounter with God.

In 1919, the General Association passed two crucial resolutions which demonstrated allegiance to the fundamental doctrines but revealed they did not want to go as far as the more extreme fundamentalists in abandoning ecumenism. West Virginia Baptists were ready to participate in the Interchurch World Movement, provided, as the Convention had stipulated, that such interdenominational collaboration would not compromise Baptist autonomy. ${ }^{92}$ In a much more popular move, the state group passed a lengthy resolution supporting the New Hampshire and Philadelphia Confessions of Faith. The delegates also specifically enumerated the doctrinal positions they deemed most essential to the Baptist faith. First, they listed the fundamentals:

full inspiration and infallibility of the Bible; total depravity of man, or that he is by nature dead and corrupt in trespasses and in sins; necessity of regeneration; in the virgin birth; death of Christ. . . as our substitute. . . blood atonement. . . only atonement; literal resurrection from the dead; in his promised literal return; resurrection and everlasting punishment of the wicked. ${ }^{93}$

Second, the resolution affirmed classic Baptist distinctives, such as the autonomy of the local congregation, the necessity of believer's baptism by immersion as the prerequisite to church membership, and adherence to the Bible as the only standard of faith and practice. ${ }^{94}$

The Baptist Banner also revealed the religious mood of West Virginia Baptists. Articles articulating conservative theological positions appeared with increasing regularity in the newspaper between 1910 and 1922. A brief 1907 article showed a clear understanding of the issues plaguing the Northern Baptist Convention. Even at this comparatively early date, the

\footnotetext{
92“"Resolution," Minutes of the Baptist General Association of West Virginia (Parkersburg, WV: Sentinel Publishing, 1919), 44.

93“Johnson Resolutions," Minutes of the Baptist General Association of West Virginia (Parkersburg, WV: Sentinel Publishing, 1919), 39.

94“"Johnson Resolutions,” 39.
} 
author showed concern about liberalism in Baptist seminaries eroding confidence in Scripture. The higher criticism taught at many such institutions of higher education undermined both the salvific message of the Bible and its historical accuracy. ${ }^{95}$

As the fundamentalist/modernist conflict within the national denomination escalated towards the end of the 1910s, articles on the core tenets of the faith and the battle to preserve them appeared in almost every issue of The Baptist Banner. Many of them dealt directly with the proceedings of the NBC. Coverage in the state paper highlighted the importance and ubiquity of the issues. Topics and concerns often appeared in the state paper, and also in the state association minutes, before they erupted publicly at the national convention. The necessity for a single statement of faith was one example. West Virginia Baptists officially endorsed the New Hampshire and Philadelphia Confessions three years before the subject came up for a vote on the floor of the NBC. In 1918, a year before the state resolution, an article appeared in favor of a confession. "But far too many, influenced by love for the seemingly liberal, do not 'earnestly contend for the faith once delivered to the saints,"' its author W.L. Richardson maintained. The confessional tradition, on the other hand, kept Baptists grounded in the faith and ensured that they really were contending for that faith. Baptists must not be afraid to confess, to truly declare, what they believe and why. ${ }^{96}$

While the fundamentalist/modernist controversy affected most of the major Protestant denominations, Baptists defended their position in a uniquely Baptist fashion. Roscoe Murray, an assistant editor of The Banner, argued that the ideas of individual soul liberty and the priesthood of the believer could not be used to reject other essential truths of Scripture. "The

\footnotetext{
${ }^{95}$ I.M. Lake, “Religion Not Of Divine Origin,” The Baptist Banner XVIII (July 25, 1907), 7, 15.

${ }^{96}$ W.L. Richardson, “Weak Places in West Virginia Baptists: Part II,” The Baptist Banner XXIX (Feb. 14, 1918), 14, 15.
} 
liberty of the individual Conscience ceases when it comes to a matter Fundamental and plainly taught in God's Holy Word," he explained. He concluded by getting to the heart of the issue the trustworthiness of Scripture - and connected it directly with being a true Baptist. "The Bible is God's Infallible Word and we must remember that our personal liberty is bounded by it. Baptists accept that Word as an all sufficient guide. To cease to accept it as such is to cease to be a loyal Baptist." 97

So great was the perceived threat to biblical Christianity that some even identified developments in the Convention and in the rest of mainline Protestantism with the prophesied apostasy of the end times. T.C. Johnson, pastor of the Baptist Temple in Charleston and a leading force in state denominational affairs, argued that the liberalism, modernism, and social gospel of his day defined the "falling away" mentioned in II Thessalonians 2:3. Modern liberals, he asserted, were far greater apostates than even the Roman Catholics of the Middle Ages: "Even the Romish Church did not fall away from the great fundamentals. They held all through the dark ages to the virgin birth, the deity of Christ, the miracles, the resurrection of Christ, the necessity of regeneration, the inspiration of the Bible, etc.,". 98

This association of theological liberalism with biblical prophesies about the end times and the second coming of the Lord fit nicely into the dispensational premillennialism that by this time was popular in Baptist churches across the country. Many leading Baptists became dispensational premillennialists, but neither dispensationalism nor premillennialism was among the fundamentals listed by Baptists or any other denomination at the time. The staff of the

\footnotetext{
${ }^{97}$ Roscoe Murray, “Making License of Liberty.” The Baptist Banner XXXII (Aug. 15, 1921), 7.

${ }^{98}$ T.C. Johnson, “The Great Apostasy,” The Baptist Banner XXXI (March 11, 1920), 6.
} 
Banner recognized that both pre- and postmillennialists were orthodox. The truly important point was a belief in the literal return of Jesus. ${ }^{99}$

Fundamentalist, dispensational premillennial theology did not mean West Virginia Baptists remained unconcerned with the pressing social issues of the day. Theological conservatism did not equal being socially or politically reactionary. West Virginia Baptists had a long history of social concern and reform activism, taking up temperance concerns in the mid1870s. In the early years of the twentieth century Baptists also took up the cause of Sabbathreform, and over the following forty years, temperance and Sabbath reform remained priorities. The new social conditions caused by industrialization, urbanization, and immigration exacerbated the problems of alcohol abuse. During the last quarter of the nineteenth century, the labor problem became the major reform issue of the day. Reformers, secular and sectarian alike, identified that as a root cause of many other social ills and vices, including alcohol use and Sabbath-breaking.

The West Virginia Baptist response to the labor question and related social problems demonstrated the conservatism of that denomination, and, to a certain extent, the validity of some of Marsden's assertions about the Great Reversal. The General Association did not form a social service committee until 1914. In its first report on social service, labor was grouped with several other concerns and was treated briefly and in general terms, although generally favorable to the working class. The committee suggested "that every Baptist church in West Virginia be urged to take up the matter of social service as it may be necessary in its own community."100

\footnotetext{
99“"Purely a 'Domestic' Issue," The Baptist Banner XXXII (Sept. 1, 1921), 5. The Baptist Banner also defended a literal reading of Genesis, which was another corollary to the idea of the inspiration and infallibility of Scripture. In addition to editorial pieces against evolution, a reprinted article defending literal six-day creation by William Jennings Bryan appeared several times between 1918 and 1923.

100“"Report on Social Service," Minutes of the Baptist General Association of West Virginia (Parkersburg, WV: Sentinel Publishing, 1914), 18.
} 
The term "social service" was not specifically defined. Yet the General Association encouraged churches to cooperate with the state legislature and local city councils and county commissions. Finally, the report included a list of traditional and progressive reform causes.

Baptists supported legislation in the following areas:

sanitation and morals in hotels and lodging houses; industrial education and protection of employees; parks, playgrounds, and recreation centres; theatres, dance halls and moving picture shows; Sunday observance and seventh day rest for all toilers; pure food laws and regulations of markets, groceries and dairies; the white slave traffic and the social evil in all its forms; child labor and protection of women as employees; and in general the social betterment of all our communities in city and country alike. ${ }^{101}$

The social service committee issued just two more reports, in 1915 and 1916. There were some key similarities between the 1915 state report and many of the reports from the national Convention's Social Service Commission. Baptists at both levels believed that the principles of Christianity should be applied in public settings. "Social service, rightly defined, is practical Christianity," declared West Virginia Baptists. ${ }^{102}$ To some extent, the concept of the universal fatherhood of God and the univseral brotherhood of man, one of the major theological underpinnings of the social gospel, was also evident in the state report. "The ideal Social order is one in which the relation of men to God is that of Sons; and the relation of men to one another is that of brothers," the statement reads. ${ }^{103}$

Furthermore, like the social gospelers in the Northern Baptist Convention, West Virginia Baptists sought to improve material conditions, not just spiritual ones. At the same time, however, the state report connected the notions of fatherhood, brotherhood, and sonship to personal salvation in much clearer and more direct ways than did the ones authored by theological liberals.

\footnotetext{
101،Report on Social Service," 1914, 18. Emphasis theirs.

102“"Report of Social Service," Minutes of the Baptist General Association of West Virginia (Parkersburg, WV: Sentinel Publishing, 1915), 56. Emphasis theirs.

103،"Report of Social Service," 56.
} 
Sonship resulted from salvation, and thus the full intimacy of the divine familial bonds could felt and enjoyed only by those who experienced genuine conversion. Finally, the most glaring feature of the three social service reports from the Mountain State was the complete absence of the Kingdom of God. That core premise of the social gospel was nowhere to be found.

Thus, while Baptists in West Virginia expressed legitimate concern over the physical and social welfare of humanity, they, like many of the nineteenth century reformers, saw social reform purely as a function of personal salvation and not as something that could be truly achieved without it. Throughout the first decades of the twentieth century, they retained the traditional commitment to social issues that Marsden associated with conservative Christians of the second half of the nineteenth century. The short life span of the social service committee could also be due to the Great Reversal, although perhaps in this case it could be better called the "Quick Turnaround." Despite, or perhaps because of, their close proximity to the industrial situation, West Virginia Baptists soured on the idea of social service as an official program of the denomination.

The fact that many church members in the mountain regions most drastically affected by industrialization during this time were themselves members of the working class further complicates the issue. Even though egalitarian church polity meant that people from all classes could and did serve in leadership positions in the local church, there was no indication that working class parishioners ever attempted to get their collective voice heard at the local and state associations, let alone any indication that this alternative perspective was recognized. In 1916, the chairman of the social service committee lamented that the labor movement accepted Jesus as a social leader but rejected Christ as a redeemer. ${ }^{104}$ However, even that statement is ambiguous, as

\footnotetext{
104،"Report of Committee on Social Service," Minutes of the Baptist General Association of West Virginia (Parkersburg, WV: Sentinel Publishing, 1916), 63.
} 
there is scant evidence that organized labor, whether moderate or radical, ever found notable support among working class Baptists in the Allegheny region.

No mention of labor appeared in the local associations encompassing the Allegheny region until 1921, after most of the track had been laid and the timber industry had started to decline. Even at that late date, views expressed on the matter remained very conservative and showed no evidence of the social gospel influence and no mention of the kingdom. While traditional in approach, a resolution by the Union Association was very clear about Baptist support of labor. The association wished to cooperate with labor and bring about "amicable relationships between all classes of laborers, as well as between capital and labor." ${ }^{105}$ However, while not directly stating it, the churches seemed to want to keep labor subordinate, ensuring that it did seriously threaten the existing social order. "[W]e condemn all lawlessness by whomsoever perpetrated," concluded the resolution. ${ }^{106}$ Thus, Baptists in the mountains remained largely silent on the new "social question" and expressed conservative views when they did speak about it.

\section{Conclusion: Fundamentalism, the Social Gospel, and Popular Religion}

Throughout the Progressive Era, mainstream Protestants in the mountain counties of West Virginia, and in the state as a whole, continued to understand their religion and its teachings in traditional ways, although theological liberalism and the social gospel certainly made inroads into the state. The presence, even dominance, of heavy industry, the influx in population, and resulting social and cultural changes raised the possibility that new measures might be required. At the same time, however, conservative impulses within Methodist, Presbyterian, and Baptist ranks ensured that while service still would be a priority, traditional understandings of doctrine would not be displaced.

\footnotetext{
105“Special Resolution,” Minutes of the Union Association, 1921, 11.

106،"Special Resolution," 11.
} 
Perhaps more importantly, the study of the major Protestant denominations in West Virginia raises questions about the adequacy of broad and generalized studies and conclusions about the social gospel and fundamentalism. The "Great Reversal" paradigm describes some aspects of the reaction to social gospel liberalism, but it seems that this method errs by seeing the people involved first as liberals or conservatives, and then as members of particular churches. Reprioritizing would help. Liberalism and conservatism crossed sectarian boundaries. However, denominational distinctives influenced how liberalism and conservatism would manifest in individual believers and how much impact movements such as the social gospel or fundamentalism would have.

The different responses to the social gospel, whether positive, negative, or indifferent, stemmed from distinctions among the denominations rooted in their histories and heritages. All drew from a common well, and the core doctrines cited by conservatives and fundamentalists in each group spanned denominational barriers, but the social gospel recognized that thought determined action. Supporters not only called for a re-evaluation of the relationship between idea and deed, but they also came to the conclusion that it might be necessary to re-interpret doctrine to provide an appropriate foundation for praxis.

In some sense, Southern Presbyterians "became" fundamentalists because "fundamentalism" came into existence. ${ }^{107}$ Southern Presbyterians, grounded in scholasticism and the spirituality of the church, remained reluctant even to consider any reform efforts beyond temperance and Sabbath-keeping. They interpreted the beliefs and positions associated with fundamentalism as an accurate representation of their faith. They were conservative in their theology, and they defended those positions against theological liberalism, but the comparative lack of social gospel

\footnotetext{
${ }^{107}$ Recall Collins, "fundamentalist quadrilateral:" militancy, social ambivalence, sectarianism, biblio-centricism. See Chapter 1 for more detail. See also Collins, The Evangelical Moment, 36, 37.
} 
and modernist opposition at state and national levels meant that they were less militant than their Northern counterparts, especially during the Progressive Era. The PCUS churches also drew their theology from different sources and contexts.

Northern Baptists in West Virginia temporarily "became" fundamentalists as they were drawn into the fight against liberalism in the Northern Baptist Convention. At the same time, doctrinal dissent hardly existed at the state and local levels, and the social gospel really never took root. Drawing upon strong commitments to individual salvation and freedom of conscience, West Virginia Baptists equivocated on what exactly the church should do in the secular sphere. As a whole, they believed "the fundamentals" were just succinct expressions of classic Baptist positions and that social reform was an extension of individual salvation rather than a distinct end in itself. Dispensationalism, common in some fundamentalist circles, increased, but by no means became the dominant view at the time in West Virginia. As the national controversy faded in the mid-1920s, Baptists at state and local levels seemed to abandon the fight against "heresy" as quickly as they had joined it, remaining theologically conservative but in some sense ceasing to be fundamentalist. They did not even consider departing for the Baptist Bible Union (later the General Association of Regular Baptists) with other fundamentalists in 1923 or the Conservative Baptist Association, formed in 1947 (see Chapter 6.).

Methodists possessed Wesley's golden coin of personal holiness and social holiness. One could not exist without the other. Generally speaking, the MEC, nationally and in West Virginia, showed greater concern for the new industrial order than its Southern counterparts and exhibited at least some greater willingness to apply distinctly social gospel principles to the new problems in search for solutions. At the same time, Methodists in West Virginia clearly believed in the 
compatibility of new social action and traditional faith. They saw no reason why social action should undermine doctrine or require that it change.

Southern Methodists showed greater reluctance to embrace new ideas about the kingdom and social holiness, but they also displayed far less doctrinal militancy than Baptists and Presbyterians in the region and should not be called fundamentalist any more than the MEC should be. ${ }^{108}$ To be sure, both Methodist groups took official positions, but perhaps due to their traditional Wesleyan theology they did not condemn the ideas contained in the Social Creed or the actions of the Federal Council of Churches. The difference between the MEC response to the social gospel and the MEC, South was quantitative, not qualitative. Both saw themselves as heirs of Wesley and faithfully representing his legacy.

These denominationally-conditioned responses to the social gospel and fundamentalism also shed light on popular religion. Charles Lippy points out the similarities between fundamentalism and popular religion. "At its base, fundamentalism was compatible with the religiosity of the people, for both assumed the reality of supernatural power and the prevalence of supernatural forces at work in the world," he argued. ${ }^{109}$ Baptists, Presbyterians, and Methodists were not known for overt supernatural workings of grace such as speaking in tongues or faith healing, and it would be inaccurate to label all mainstream Protestants in West Virginia as fundamentalists. It can even be difficult to define clearly the boundary between conservative and fundamentalist in mountain churches.

There are other ways, however, that mainline Protestants in the mountains exhibited popular religion. These were perhaps less overt than doctrinal militancy or charismatic worship, but

\footnotetext{
${ }^{108}$ Collins, 45-48; Carl E. Burrows, Robert B. Florian, and David F. Mahoney, Melting Times: A History of West Virginia United Methodism (Charleston, WV: Commission on Archives and History, 1984), 280.

${ }^{109}$ Charles Lippy, Being Religious, American Style (Westport, CT: Praeger, 1994), 167.
} 
on some level they represent a simpler, more elemental religiosity that highlights the "popular" in popular religion. The members of each group consistently attested to those supernatural works of grace common to every Christian as a called, repentant, and faithful child of God. Furthermore, by understanding the religious issues of their day in terms of their respective faith traditions, all of which affirmed in one way or another those doctrines most closely associated with fundamentalism, members of these congregations became intimate and integral parts of their churches as communities and institutions.

It would be even more inaccurate to designate mainstream West Virginia Protestants as social gospelers, but their tepid collective response to the social gospel is useful in describing popular religion in the mountains. Religious scholar Peter Williams called the theology of the likes of Rauschenbusch and Ward "the High Social Gospel," which "fell far short of becoming the 'stuff' of poplar Protestantism." However, he also identified a "low or evangelical Social Gospel." This dealt little with theological minutia one way or another; it combined "evangelical morality and conservative Progressivism." ${ }^{\prime 10}$ In this way, the social gospel could very much reflect popular religion, as common parishioners banded together to work largely independent of direct denominational control, such as in women's missionary organizations or the MEC student movement for global Christian democracy.

Given the paucity of these types of organizations in the mountains, it remains doubtful that the social gospel as such constituted a viable form of popular religion in the region. This in no way means that believers remained unmoved by the situations of working people, the poor, and others dispossessed in modern America. In light of how the various denominations responded to the "high Social Gospel," social action in the mountains remained rooted in conservatism,

\footnotetext{
${ }^{110}$ Peter W. Williams, Popular Religion in America: Symbolic Change and the Modernization Process in Historical Perspective (Englewood Cliffs, NJ: Prentice-Hall, 1980), 139.
} 
and thus the social gospel really did not constitute a form of popular religion in the Alleghenies. This trans-denominational conservatism, which was also demonstrated in other ways in other chapters, meant West Virginia Protestants continued to believe church authority derived first and foremost from God and the Bible, and secondarily, if at all, from its association with secular sources of authority or from its appropriation of secular ideologies or theories. The church's ability to minister to the secular world came precisely from the independence of that sphere, and so the church would therefore be free to determine exactly how it would speak and what the message would be. 


\section{8: Moral Reform}

\section{A Protestant America, A Protestant West Virginia}

Mainline Protestants disagreed and divided over the best responses to the changing social and economic conditions of the Gilded Age and Progressive Era. The development of the social gospel and fundamentalism suggested a disintegration of the Protestant consensus in America. On a deeper, more historic level, the nation's largest denominations remained united in their vision for the country and elementary ways to make that a reality. Mission work stemmed from a genuine concern for souls. However, evangelism also involved important cultural elements.

Northern missionaries saw cultural uplift as part and parcel of their labor in the Southern mountains, often viewing the local people as the "other." They wanted to incorporate West Virginia into the mainstream of American life. Of course, the West Virginia Baptists, Methodists, and Presbyterians working in their home state did not see their field as foreign or the people as different. They too wanted to improve the religious and moral life of residents; they too wanted West Virginia to take its rightful place in Christian America. West Virginians as a whole wanted the same thing. For example, business and political leaders such as Henry Gassaway Davis and Stephen B. Elkins predicated their secular endeavors on the premise that the Mountain State could become a leader in modern industrial America. The goals of missionaries and industrialists often overlapped, with sacred and secular forces supporting each other. At other times, when these visions of a modern, industrial, moral civilization conflicted, the values of the business class usually won. Morality would be an important component of an industrial West Virginia, but secular authorities, specifically industry, took on an increasingly prominent role in defining the parameters of that morality. ${ }^{111}$

\footnotetext{
${ }^{111}$ John C. Hennen, The Americanization of West Virginia: Creating A Modern Industrial State, 1916-1925 (Lexington: The University of Kentucky Press, 1996), 135, 149.
} 
Despite divergent views on the mountain mission field, West Virginia missionaries and their Northern counterparts shared a common goal. The gospel made up the cornerstone this of efforts to improve people. Liberals, fundamentalists, and everyone in between agreed that certain behavioral changes should be evident in a life transformed by God. Two of the most prominent moral concerns on which all mainstream Protestants agreed were Sabbath-keeping and temperance. In America, Methodists, Baptists, and Presbyterians each had long histories of championing these causes in various ways. Grouped together under the aegis of "moral reform," these captured the connection between sacred and secular, blurring distinctions between the old and new orders. Religious historian Robert Handy points out that while the quest for Sabbath observance stemmed largely from a desire to preserve past practices, the quest for temperance and prohibition was relatively new, and that "the adding of temperance to the definition of Christian civilization was for the most part an innovation of the nineteenth century."

These issues represented an evangelical sentiment that clashed with traditional understandings of masculinity in the rural and mountain South. Men did not so much reject the power of the church and the importance of the sacred in everyday life, public and private, but the concept of masculinity that constantly demanded aggressiveness, assertiveness, and toughness prevented the church from making an unchallenged claim on the behavior of members and attendees. Industrialization exacerbated this reality. The requirements of factory work and the increase in the single male population suggested that vices would increase. ${ }^{113}$ At the same time,

\footnotetext{
${ }^{112}$ Robert T. Handy, A Christian America: Protestant Hopes and Historical Realities (New York: Oxford, 2004), 45.

${ }^{113}$ Ted Ownby, Subduing Satan: Religion, Recreation, and Manhood in the Rural South, 1865-1920 (Chapel Hill: The University of North Carolina Press, 1900), 130-134. See also Joe L. Coker, Liquor and the Lost Cause: Southern White Evangelicals and the Prohibition Movement (Lexington: The University of Kentucky Press, 2007).
} 
industrialists found much use for moral reform, especially temperance, as a drunken and disorderly work force was bad for business.

Such Protestant mores also clashed with values, traditions, and practices of many of the immigrant groups coming into the country throughout the Gilded Age and Progressive Era. Southern and Eastern Europeans, many of whom were Catholics and Jews, adhered neither to Protestant standards on Sunday nor those on drinking. A diverse cross-section of those groups came to Appalachia in general and West Virginia in particular. Thus, both issues rose to prominence nationally and regionally in the 1880s in large part because significant segments of the population now had no grounding in the Puritan legacy. ${ }^{114}$

The fact that many West Virginia Protestants viewed these newcomers as uncivilized, backwards, brutish, ignorant, and racially inferior bolstered the association of certain behaviors and practices with the idea of a Christian civilization. Since many of the countries in Southern and Eastern Europe remained technologically and politically underdeveloped, some native-born Americans saw a causal connection between morality and temporal progress. Immigrants' lifestyles were deemed simply incompatible with American society. ${ }^{115}$ A variety of groups, including the major Protestant denominations, attempted to rectify this situation. Temperance and Sabbath-keeping were major reform efforts in their own right, but those issues personified how many Protestants viewed the changes occurring in society at the time and the relationship between the sacred and secular.

Sacred Calls for Reform

\footnotetext{
${ }^{114}$ Alan M. Kraut, The Huddled Masses: The Immigrant in American Society, 1880-1921 (Wheeling, IL: Harlan Davidson, Inc., 2001), 179-181; Charles W. Calhoun, ed., The Gilded Age: Perspectives on the Origins of Modern America (New York: Rowman \& Littlefield Publishers, Inc., 2007), 273.

${ }^{115}$ Matthew Fyre Jacobson, Barbarian Virtues: The United States Encounters Foreign Peoples At Home and Abroad, 1876-1917 (New York: Hill and Wang, 2000), 3-8.
} 
Methodists, Baptists, and Presbyterians wanted to check moral and religious decline in the mountains, and, if possible, reverse it. By doing so, they hoped to elevate their state to a position of prominence in modern America. Moral reform must take place, but the three groups disagreed on exactly how to implement it. Furthermore, each took a different position on which particular aspect of reform was most important. Methodists used the phrase "moral reform" as a catch-all that included a variety of social issues considered vital to the individual Christian life and to the health and prosperity of society. Nationwide, Methodists took the lead in these classic American reform initiatives. The ME Church and the MEC, South believed these matters served important functions in American life, supporting American civilization. Declension in these areas would contribute to the erosion of society and culture. The moral health of the nation served as a barometer for its material health. As the former rose, so would the latter. If the former declined, so would the latter. Thus, through the late nineteenth and early twentieth centuries, Methodists exerted considerable effort to ensuring that the traditional Protestant position on these issues remained the standard across the country. To that end, they were willing to employ an array of means, ranging from individual example to national legislation.

While both temperance and Sabbath observance constituted major concerns for Methodists, that denomination placed far more emphasis on temperance. Georgia Harkness argues that temperance took precedence over every other social issue and was in fact an expression of the social gospel. That it may have been, but Methodist activity on temperance long predated the social gospel, and many with no interest in or even antagonism toward the social gospel labored tirelessly against demon rum. ${ }^{116}$ It was this widespread support which made Methodism such a

\footnotetext{
${ }^{116}$ Georgia Harkness, The Methodist Church in Social Thought and Action (New York: Abingdon, 1964), 54. In The Methodist Experience in America, A History (Nashville: Abingdon, 2010), 335, 336, Russell E. Richey, Kenneth E. Rowe, and Jean Miller Schmidt concur with Harkness's assessment of the importance of temperance to the Methodists across the country. Despite the increasing popularity of the Social Creed in the ME Church, anti-alcohol
} 
powerful force in the temperance movement. Methodists played prominent roles in three significant non-sectarian dry organizations - the National Prohibition Party, the Women's Christian Temperance Union, and the National Anti-Saloon League.

They also did not hesitate to bring the full power of their denomination to bear on the subject. Both the MEC and the MEC, South frequently issued lengthy temperance reports, often calling upon the federal government to take immediate action. In 1884, the MEC, which had long demanded total abstinence from its members, now insisted on nothing less than a prohibition amendment to the United States Constitution. Appreciating the difficulty of such an undertaking, it was willing to advocate, in the meantime, for state and local temperance laws. In any case, alcohol must be driven from the land. The General Conference formed a temperance committee in 1892, upgrading it to a board in 1904. ${ }^{117}$

The General Conference of the ME Church, South echoed this sentiment in 1890. Genuine personal temperance must be voluntary, but it was still the duty of the government to legislate against liquor. ${ }^{118}$ Whereas the ME, Church General Conference itself took the lead in temperance campaigns, Southern endeavors were more decentralized, with less cooperation among the various annual conferences. Regardless of those differences, Methodists of both branches in

activism far outweighed any struggles for economic equality or increased recognition of organized labor. Denominational support for both temperance and Sabbath-keeping dated to Francis Asbury's pioneering missionary work in what were then the British colonies. While Wesley himself opposed both drunkenness and social drinking, some other early Methodists disagreed. In the early national period, only clergy were required to remain dry. Lay people could drink in moderation, but were strongly advised not to do so. In 1832, the General Conference formed a committee on temperance, which called for total abstinence. However, at the state and local levels, many Methodists organized temperance groups before the 1830s. Methodists began to see both temperance and the Sabbath as two sides of the same coin and foundational to civilization. While usually favoring voluntary and cooperative means, Methodists increasingly expressed a willingness to call upon the government to enforce morality. See William G. McLoughlin, Revivals, Awakenings, and Reform (Chicago: University of Chicago Press, 1978), 112-114; Betty O'Brien, “The Lord's Supper: Fruit of the Vine or Cup of Devils?," Methodist History 31, no. 4 (1993), 204, 205; and Harkness, 19, 20, 31, 32.

${ }^{117}$ Frederick A. Norwood, The Story of American Methodism (Nashville: Abingdon, 1974), 394.

${ }^{118}$ Norwood, 394. 
West Virginia saw these matters in much the same way. The annual conferences mobilized at different times, and disagreed on the minutia, but they all shared common assumptions about the nature of the problem and the overarching remedy.

In 1882, the West Virginia Conference of the Methodist Episcopal Church called for a state constitutional prohibition amendment as the only solution to the liquor problem. That body also pledged to vote only for "open and avowed temperance men" who would help rid the state of "the mildew and blight of the rum traffic." With the proliferation of non-denominational temperance groups, increased cooperation outside institutional religious confines also appeared promising. In 1887, the MEC annual conference voted to cooperate with all anti-Saloon leagues and the Women's Christian Temperance Union. ${ }^{119}$

In 1886, the Western Virginia Conference of the Methodist Episcopal Church, South called for political action against alcohol and also began coordinating dry efforts with the national temperance organizations. Southern Methodists submitted an extensive report to the annual conference on temperance which expounded on the connections between liquor and civilization. "We hesitate not to say, observation having convinced us, that intemperance is the giant foe of mankind, undermining the foundation of the social fabric and poisoning the very fountain heads of society." They went on to declare "the liquor traffic everywhere is the giant foe of Church and State."120

That same report also mirrored many of the concerns that non-sectarian groups raised about the deleterious effects of alcohol on home and hearth. "We have seen young manhood debauched and ruined; ... childhood's sunny hours merged into shadow and blight whilst gray hairs

\footnotetext{
119“Temperance Report," Official Journal of the West Virginia Conference, Methodist Episcopal Church, 1882, 36; "Temperance Report," Official Journal of the West Virginia Conference, Methodist Episcopal Church, $1887,44$.

120،"Temperance Report,” Western Virginia Conference Journal, Methodist Episcopal Church, South, $1886,27$.
} 
have come with broken hearts to the grave," the committee lamented. ${ }^{121}$ The 1900 report further emphasized the pernicious and far-reaching impact of strong drink. Drunkards not only destroyed themselves, but they also brought "their families to want" and became "a blight on human society."122

Despite calls for political action, neither annual conference was ready to reject the moral suasion strategies employed in the antebellum era. Throughout the remainder of the nineteenth century, Methodist ministers continued to preach in favor of temperance and were instructed to do so every quarter. Sunday schools and revival meetings also devoted time to preaching about the evils of alcohol and the benefits of sobriety. ${ }^{123}$ By the turn of the century, however, tactics seemed to change abruptly. Strong denunciations of alcohol and vehement calls for state and federal constitutional amendments continued, but local success in reducing alcohol consumption coincided with a marked decline in local temperance preaching. The $1900 \mathrm{ME}$ Church, South report, for example, contained no mention of preaching or any other distinctly church-based efforts. Rather, government action and cooperation with non-sectarian groups garnered all the at-

\footnotetext{
121،“Temperance Report,” Western Virginia Conference Journal, Methodist Episcopal Church, South, 1886, 27.

122،"Temperance Report,” Western Virginia Conference Journal, Methodist Episcopal Church, South, 1900, 40, 41.

${ }^{123}$ Both Baltimore Conferences and the Virginia Conference of the ME Church also contained counties lying within the Alleghenies. With large urban areas and black membership, these conferences had different social and racial compositions than their transmontane brethren. Nevertheless, they too concurred on temperance. For example, see "Report on the Committee on Temperance," Minutes of the Baltimore Annual Conference of the Methodist Episcopal Church, South (Baltimore: King Brothers, 1885), 48; "Report on the Committee of Temperance," 1900, 66, 67; "Report on the Committee of Temperance," 1910, 82, 83; "Temperance Cause," Minutes of the Baltimore Conference of the Methodist Episcopal Church (Baltimore: William K. Boyle \& Son, 1875), 61, 62; "Temperance," 1886, 67, 68; "Temperance Report," Minutes of the Virginia Conference of the Methodist Episcopal Church (Alexandria: W.P. Grand and Co., 1885), 16, 17; “Temperance," 1890, 24. In its 1920 report on temperance and social service, the Baltimore Conference, MECS petitioned the United States Congress and the President to change the preamble of the Constitution to reflect the indebtedness of the nation to God. The amended introduction would read, in part, "We, the people of the United States, devoutly recognizing the authority and law of Jesus Christ, the Saviour and King of nations, and desiring to form a more perfect union." They believed this insertion to be "effective Christian propaganda." "Temperance and Social Service - Report 2," Minutes of the Baltimore Conference of the Methodist Episcopal Church, South (Baltimore: King Brothers, 1920), 68, 69.
} 
tention. In just a few decades, the Methodists significantly de-emphasized practices they had seen for more than one hundred years as fundamental to moral reform of any kind.

While West Virginia Methodists worked to extinguish what they saw as a pernicious evil, they also strove to preserve what they considered a hallmark of their faith and of their country: they continually condemned leisure and work on Sunday. On the national level, however, the two largest branches of the denomination devoted significantly less time to the Sabbath than to temperance. By contrast, the MEC and the MEC, South, especially after the turn of the century, usually connected concern for this issue with other social issues. The Social Creed, for example, which both groups adopted, asserted that workers had a right to rest one day out of seven. ${ }^{124}$

The annual conferences, on the other hand, devoted considerable attention to the Sabbath. Both wings of the church believed the day stood as a cornerstone of American life, and so must be defended. As early as 1875, the Baltimore Conference of the ME Church, which included churches in the eastern panhandle of West Virginia, recognized the link between the sacred day and secular society. Worldly amusements, sports, leisure activities, and unnecessary labor all profaned the Sabbath and violated God's law. They asserted that the Fourth Commandment (observing the Sabbath) was binding on all people, and that "no nation can attain a true elevation of Christian civilization that disregards it."

In 1880, after a lengthy explanation of the function of the Sabbath, the annual conference concluded that railroads and other large businesses contributed to its desecration and subsequent "social disorder and communism" more than any other factor, including new immigrants who came to these shores with no respect for the day. They called for legislation to protect the Sab-

\footnotetext{
${ }^{124}$ Harkness, 40, 47.

125“'Sabbath Observance," Minutes of the Baltimore Annual Conference of the Methodist Episcopal Church (Baltimore: William K Boyle and Son, 1875), 57.
} 
bath against its corporate foes. ${ }^{126}$ Over the course of the Gilded Age and the Progressive Era, these Methodists continually maintained that observing the Sabbath undergirded American society and served as a moral anchor. ${ }^{127}$

The Baltimore Conference of the ME Church, South issued the first of few Sabbath reports in 1890. While it stopped short of calling for legislation, it applauded those who worked for such goals and believed that the state did possess the authority to enact such laws. Unlike its MEC counterparts, however, the MEC, South Baltimore Conference expressly instructed its pastors to increase teaching and preaching on the subject. The annual conference did not issue another Sabbath report until 1920, although its approach remained the same over the three decades. It still supported the work of organizations such as the Lord's Day Alliance, but the ecclesiastical body did not directly call for legislation. It did, however, "believe this day (Sunday) to be one of the fundamental principles of our national civilization and security.",128

126“'Sabbath Observance," Minutes of the Baltimore Annual Conference of the Methodist Episcopal Church (Baltimore: Methodist Episcopal Book Rooms, 1880), 72, 73.

${ }^{127}$ Their co-religionists in the Virginia Conference came comparatively late to Sunday's defense, but they adopted a similar stance. Starting out by simply calling upon their ministers to preach at least two sermons a year on the subject, they shortly called for "all legitimate means be used to secure a proper observance of the Lord's Day." See Sabbath Observance," Minutes of the Virginia Conference of the Methodist Episcopal Church (Hampton, VA: Normal School Press, 1890), 30; "Sabbath Observance," Minutes of the Virginia Conference of the Methodist Episcopal Church (Hampton, VA: Normal School Press, 1895), 25.

128“"Report of the Committee on Sabbath Observance," Minutes of the Baltimore Annual Conference of the Methodist Episcopal Church, South (Baltimore: King Brothers, 1890), 59, 60; "Report of the Committee on the Sabbath Observance," Minutes of the Baltimore Annual Conference of the Methodist Episcopal Church, South (Baltimore: King Brothers, 1920), 65, 66. The West Virginia Methodists in the West Virginia (ME Church) and Western Virginia (ME Church, South) Conferences concurred. Over the course of the 1890s, members of MEC congregations petitioned the state and local governments to pass and enforce Sabbath laws. However, Sabbath reports faded from conference records in the early 1900s. Their Southern Methodist counterparts in the Western Virginia Conference also did not take up the cause in earnest until 1890. They never directly petitioned the government to enact Sabbath legislation. However, they did keep the issue at the forefront of their meetings well into the Progressive Era. Most of the pro-Sabbath work the Western Virginia Conference engaged in consisted of educating members and the public as a whole about the importance of the Lord's Day, an approach generally consistent with that of the rest of the Methodist Episcopal Church, South. See Report of the Committee on Observance of the Sabbath," Official Journal of the West Virginia Conference, Methodist Episcopal Church, 1890, 41; "Committee on Observance of the Sabbath," 1896, 37, 38; and "The Sabbath," Western Virginia Conference Journal, Methodist Episcopal Church, South, 1890, 47. 
The temperance and Sabbath positions of Methodists in the mountains of West Virginia showed firm commitments to the Methodist heritage and to the vision of an America based on distinctly Protestant morality. The church's willingness to pressure local, state, and federal governments on these issues implied that members living in an emerging modern industrial economy saw themselves as part of a nation unified by common allegiances to secular progress fueled by moral and spiritual progress. Over the course of the Gilded Age and Progressive Era, Methodists across the country saw the church's role as both public and private. The church would minister to its members, but it would also be a voice of righteousness to those in positions of power within the secular sphere. With the exception of the Western Virginia Conference, calls to preach about temperance and Sabbath declined as the years passed. This did not mean that other pulpits fell silent on those issues. Rather, it could be that Methodists believed they should concentrate on persuading secular authorities, as their own people were firmly in the temperance and Sabbath camps. While on one hand this suggests an increased public presence for the church, especially in the case of temperance, the very fact that this high profile was required indicates that Methodists, along with other Protestants, felt their position as arbiters of national morals were threatened. The uneasy status of the Sabbath points to this conclusion.

While nationwide Baptists championed the Sabbath longer than they did temperance, in West Virginia Baptists quickly established their position on temperance while remaining formally silent on the Sabbath. No doubt they advocated its observance; it seems they did not deem that conditions in the state at that time warranted a specific declaration of principles regarding Sunday rest. That would change. In the meantime, they charted a course on temperance that put them at the forefront of the state dry movement and which represented their efforts to resolve the tension between separation of church and state in a Christian civilization. 
In 1874, just nine years after forming, the Baptist General Association issued its first temperance report. Citing an array of clergy, professors, and journalists from the United States and England, the report included numerous statistics on the dangers of alcohol - increases in orphans, widows, suicides, incarcerations, property and income losses, deaths, and so on. The lengthy statement went on to praise the recent formation of the Woman's Christian Temperance Union and the entrance of women into the fight against "King Alcohol." The General Association expressed great confidence that these new crusaders for righteousness would help turn the tide of the battle. ${ }^{129}$

The report continued with a strong denunciation of alcohol on religious grounds. "The gospel has no greater opponent than intoxicating liquors." it declared. All Christians, especially ministers, should completely abstain from all alcohol. They should also take every other step possible to fight this great sin, including petitioning the state legislature and Congress. As an ecclesiastical body, the General Association itself did not petition the state, but it did believe the state had a role to play. It called upon civil authorities to vigorously enforce existing temperance laws. $^{130}$

In 1880, the General Association initiated a comprehensive effort to ensure legal prohibition. The state body formally called upon the legislature to pass a law prohibiting the consumption, possession, and trafficking of alcohol. It also wanted to collect dry signatures from counties and towns and then send them on to the capital. Finally, it resolved to appoint a committee to

\footnotetext{
129،"Report on Temperance," Minutes of the Baptist General Association (Parkersburg, WV: Sentinel Publishing, 1874), 6-8.

130“'Report on Temperance,” 9, 10.
} 
rally all West Virginia temperance forces in convention to organize a concerted offensive against liquor. $^{131}$

It is difficult to determine the effectiveness of these campaigns. The state legislature did take up the issue of prohibition in 1888. While each anti-alcohol bill failed by a wide margin in the plebiscite, many counties did adopt local option laws. Baptists were just one voice among several calling for such results, as other denominations soon joined them in directly enlisting the aid of the state.

Over the last decades of the nineteenth century, the West Virginia Baptist position on legislative action solidified. The General Association concluded that direct and comprehensive government intervention offered the only chance to eliminate the threat. That particular report emphasized the secular nature of the problem, perhaps in an effort to further justify the Association's assertion that secular authorities must act on the problem. As "an aggressive enemy of social order," alcohol "annihilate[d] public morals and the public conscience," in addition to destroying the Sabbath and hindering the gospel. ${ }^{132}$

The saloon and the church stood as symbols of diametrically opposing ways of life. The saloon existed for the sole purpose of corrupting and degrading individuals and the culture. By contrast, the church asserted itself as an ally of peace, order, law, and good government. All

\footnotetext{
131،Report on Temperance," Minutes of the Baptist General Convention (Parkersburg, WV: Sentinel Publishing, 1880), 8. That same year, I.H. Johnson, brother of T.C. Johnson, a leading Baptist pastor and ardent foe of alcohol, founded the West Virginia Freeman, a weekly prohibition newspaper. This would be part of a concerted effort of the denomination, along with lay and clerical leaders, to reach all segments of society with the dry gospel. The paper quickly caught the eye of the Woman's Christian Temperance Union, which adopted it as its own organ in the state, pledging to considerably increase its distribution of it before the 1888 vote on the prohibition amendment. See Truett Rogers, West Virginia Baptist History: The Convention Years, 1865-1965 (Terra Alta, WV: Headline Books, Inc., 1994), 109, and "Report on Resolutions," Annual Report of the Woman's Christian Temperance Union of West Virginia, 1886-1888 (Keyser, WV: Mountain Echo Printers, 1888), 19, 69.
}

\footnotetext{
132“"Report on Temperance,” Minutes of the Baptist General Association (Parkersburg, WV: Sentinel Publishing, 1896), 26.
} 
Christians and denominations, not just Baptists, had a responsibility and a duty to do everything possible to ensure a dry victory. ${ }^{133}$

Over the course of the Gilded Age, Baptists in the mountains, working through the local associations, developed a view of temperance which corresponded closely with statewide opinion. The Eastern Association, which included churches in Mineral and Grant counties, issued a report on the subject in 1889, its inaugural meeting. Despite the infancy of the association, the statement revealed a mature and comprehensive understanding of the importance of temperance reform. "The proper business of civilized man is to promote the progressive improvement of society," the report began. Liquor, by its very nature, destroyed all it touched - the individual, the family, the nation. Thus, Baptists must oppose alcohol and strictly practice temperance. ${ }^{134}$

It would be nearly thirty years before the Eastern Association issued another report on temperance. Appearing after the ratification of the Eighteenth Amendment, the statement celebrated the ultimate defeat of alcohol and all its allies, crediting God with the victory. ${ }^{135}$ While the association approved of the constitutional amendment and had called for all Christians to stand against alcohol, it never expressly instructed believers to vote on the issue nor had the association itself ever intimated that it considered direct petitioning of the government by the church appropriate.

\footnotetext{
133،"Temperance," Minutes of the Baptist General Association (Parkersburg, WV: Sentinel Publishing, 1900), 36. For more specific examples of West Virginia Baptist involvement with temperance, see Truett Rogers, West Virginia Baptist History: The Convention Years, 1865-1965 (Terra Alta, WV: Headline Books, Inc., 1994), $108,109$.

134،"Report on Temperance," Minutes of the Eastern Association, 1889, 5.

135“"Report on Temperance," Minutes of the Eastern Association, 1920, n.p. The scarcity of temperance reports in this case should not be interpreted as a lack of concern on the matter. Of all the local Baptist associations in West Virginia, the Eastern issued the briefest reports. In most cases, these contained little more than a short outline of the meeting and the statistical reports for the constituent churches.
} 
This suggests that a narrower interpretation of the foundational Baptist doctrine of separation of church and state still held sway in some parts of the state. Interestingly, in West Virginia that view seemed to be most popular in the mountains, home to many newer congregations. The Union Association, which included churches in Randolph and Tucker counties, wrestled over the propriety of direct ecclesiastical engagement on the issue. In 1880, recognizing the deleterious effects of alcohol on every aspect of civilization, it issued its first temperance report. The association determined to "use our every effort" to eradicate alcohol. Elaborating slightly, it also noted that the state must perform its duty and enforce existing laws controlling the sale of liquor. $^{136}$

While it did not in any way specifically support government action for prohibition, the association could have intended its blanket statement to cover such an option. On the other hand, the vagueness could have been intentional, with the report meant to satisfy opposing factions. Delegates to the Union Association called upon all preachers in their areas to deliver temperance sermons as soon as possible. This emphasis on distinctly sacred measures dominated association temperance reports over the next few years. At the same time, the committee seemed to narrow its views on what other action should be taken. In 1886, its members pledged, as citizens, to "give our influence to all proper and righteous means." ${ }^{137}$ In the context of Baptist theology, this could have been a veiled rejection of direct political involvement by the churches.

This conclusion is bolstered by the report from the very next year. The association resolved that moral suasion had been tried and found wanting. Clearly that alone would not suffice. Thus, the statement urged all Christians to vote for the state prohibition amendment the

\footnotetext{
136،Temperance," Minutes of the Union Association, 1880, 6, 7.

137،"Report on Temperance," Minutes of the Union Association, 1886, 10.
} 
next year. ${ }^{138}$ To be clear, however, the association itself still stopped short of petitioning the government. In fact, in the years following the failure of the amendment, it hardened its stance against government action, favoring moral suasion once again. Political parties, liquor licenses, and local options would not work. Victory could be assured only by an educated and Christian citizenry. The home, the school, and the church must become places where young people received training in their responsibilities and duties to society, one of which, of course, was to free it from the tyrannical grip of strong drink. The association continued to support the W.C.T.U., but only in moral reform, not in political reform. ${ }^{139}$

The exact reasons for this oscillation remained unclear. For the most part, the same group of men rotated on and off the temperance committee year after year, including Elkins pastor Amos Robinson. Opinion continued to shift into the twentieth century. In 1905, the association once again complained that "moral suasion as a remedy is utterly inadequate." It once again declared it the duty of all Christians to vote dry. Once again, however, the Union Association as a body stopped short of taking any action. ${ }^{140}$

Some combination of political coercion and moral suasion seemed to be working in the mountains. In 1910, the Union Association claimed just 500 saloons operated within its bounds, down from 3,000 seven years before - yet 500 hundred saloons were far too many. That same year, a full thirty years after the General Association petitioned the legislature, the Union Association finally officially solicited the state legislature to enact prohibition. The association continued to maintain its support for traditional understandings of the separation of church and state,

\footnotetext{
138“"Report on Temperance," Minutes of the Union Association, 1887, 14.

139“"Report on Temperance," Minutes of the Union Association, 1893, 4.

140،"Report on Temperance," Minutes of the Union Association, 1905, 13, 14.
} 
even as it altered the approach to temperance. Because alcohol was injurious to civilization, the state had a duty to restrain that evil force, and the church had a duty to officially remind the state of its responsibility. This would better enable the church to promote the Kingdom. ${ }^{141}$

After three decades of wavering on exactly how to handle the issue, this group of Baptists fell in line with the rest of the state. From that point on, its temperance reports resembled those of the General Association, as well as those of the Methodists. Preaching received less and less attention. The 1913 report, for example, authored by H.W. Tiffany, pastor of the Elkins congregation, did not even discuss the ways in which churches might continue to instruct their members on the subject using the Scriptures. Rather, with ratification of the state constitutional prohibition amendment, Baptists in the mountains focused primarily on pressuring the state to enforce the law and imploring restaurants, hotels, and railroads to resist the temptation to sell bootlegged liquor. ${ }^{142}$ Through the 1920 s, preaching took a back seat to moral policing in these reports, especially with the passage of a federal prohibition amendment.

Sabbath reports began to appear much later than temperance reports in association minutes. In fact, for reasons unknown, neither the Eastern nor the Union associations issued a report on the Sabbath between 1880 and 1920 (which was common for local associations in West Virginia). When the General Association finally passed its first resolution on the topic in 1905, it mirrored the approach to temperance. Apparently, a significant and rapid increase in sporting events and rail excursions on the Sabbath prompted action. Baptists decried all such desecrations and called upon members to shun such activities. They also appointed a committee to work

\footnotetext{
141،"Report on Temperance," Minutes of the Union Association, 1910, 17, 18.

142،"Report on Temperance,” Minutes of the Union Association, 1913, 12, 13.
} 
with counterparts in other denominations. This group would bring its collective concerns on the matter before the legislature. ${ }^{143}$

A committee on Sabbath Observance was formed and the following year issued a report which overtly linked the fate of America with the fate of Sunday. "If respect for the Christian Sabbath is destroyed... then this nation, so favored by God, will go down into a deserved and shameful disgrace," the committee proclaimed. Efforts by business and individuals to profane the day constituted an "unholy conspiracy." The church must mobilize in defense of God and country. In addition to cooperating with other denominations to secure stricter Sabbath laws, Baptists called upon pastors to preach on proper Lord's Day observance. ${ }^{144}$

By 1909, the stance on Sabbath-keeping matured. God gave humanity the day as a gift, not as a punishment. The General Association developed a two-pronged approach to the issue, one which depended upon both church and state to do their respective duties. For its part, the church must practice what it preached, genuinely observing the Sabbath and educating its members about what that meant. Civil government had a responsibility to legislate on the matter because Sunday and the sacred principles it embodied were tightly woven into the national fabric. Sunday leisure activities, specifically organized sports, helped draw the youth away from those concepts. Sunday work denied workers their rights. At stake was not just a day of rest. Sabbath observance represented the priority of people over property. Desecration of the Lord's Day meant the triumph of the "fierce spirit of commercialism" - gain for the sake of gain. ${ }^{145}$

\footnotetext{
${ }^{143 ، " R e s o l u t i o n ~ o n ~ T e m p e r a n c e, " ~ M i n u t e s ~ o f ~ t h e ~ B a p t i s t ~ G e n e r a l ~ A s s o c i a t i o n, ~ 1905, ~ 47, ~} 48$.

144،"Report on Committee on Sunday Observance," Minutes of the Baptist General Association, $1906,46$.

145،'Sunday Observance,” Minutes of the Baptist General Association, 1909, 47, 48.
} 
Unlike temperance that remained a major concern of West Virginia Baptists well into the 1920s, pronounced concern for the Sabbath seemed short-lived. In 1915, a decade after the first report, Sabbath observance ceased to appear in the General Association minutes. The Association did not issue another report until 1925. Like other Protestants in West Virginia, for whatever reason, Sabbath concerns among Baptists slowly faded from public view in the early twentieth century. Indeed, West Virginia Baptists actually expressed less public concern for the Sabbath than did their Methodist and Presbyterian counterparts. Nevertheless, what they did say was congruent with the message voiced by those other groups; it was also consistent with their Baptist heritage.

While some of the basic theological views of these believers stood in stark contrast to emerging national trends in the denomination, their views on these two social issues put them well within the Northern Baptist mainstream. In some cases, the Sabbath divided liberal and conservative Protestants. Whereas conservatives wanted to restrict both work and leisure, liberals believed amusement activities should be permitted in order to allow working people to enjoy them. However, as they did with Methodists, temperance and Sabbath issues united Baptists across the theological divide. Both work and leisure constituted threats to proper Sabbath observance. ${ }^{146}$ At the Northern Baptist Convention, social gospelers usually handled social issues. As they did with Methodists, such matters fell under the aegis of the social gospel, even though, again like the Methodists, to Baptists they were also very much items of historical concern. In 1909, in just the second year of the NBC, the Social Service sub-committee supported one day of rest for laborers. In keeping with a concern for the working class, it passed a resolution denouncing compulsory Sunday labor by the postal service, calling it a "violation of the law of the

\footnotetext{
${ }^{146}$ Alexis McCrossen, Holy Day, Holiday: The American Sunday (Ithaca, NY: Cornell University Press, 2000), 56, 57.
} 
Rest Day." ${ }^{147}$ Two years later, the Social Service Commission crafted a much stronger statement in favor of the Sabbath. It still centered on labor concerns. The resolution called upon Baptists to unite with unions in the quest to re-establish Sunday as a day of rest, free from the compulsions of labor and the temptations of amusement. ${ }^{148}$

The liquor traffic, which spanned everything from the social club to the saloon, constituted "one of the most subtle foes that humanity has to meet in its upward progress." They also "reaffirm[ed] ...allegiance to the principle of total abstinence for the individual and legal prohibition for the State." The sub-committee passed a resolution supporting the various temperance societies and exhorted "all Christian voters to use their ballots for the suppression of the saloon." ${ }^{\prime 149}$ The church still had a unique and important role to play. The Social Service Commission wanted pastors and Sunday school teachers to inform their congregants and pupils on the subject of intemperance. It "summon[ed] the people to resume the old-fashioned preaching of total abstinence." 150

At the national level, these positions remained through the 1920s. In fact, due to the social gospel focus on labor rights, the Sabbath received as much if not more attention than temperance. Whereas the Methodists' attention to temperance overshadowed their concern for labor, Baptist social gospel concern for labor fueled interest in other moral reforms. At the same time,

\footnotetext{
147،Activity of the Church in Social Service," Annual of the Northern Baptist Convention, 1909, $134,153$.

148“Social Service Commission," Annual of the Northern Baptist Convention, 1911, 130. Nationally, Baptists had a long history of involvement with keeping the Sabbath. They came relatively late to temperance. They rejected drunkenness and hard liquor, but following their English predecessors, generally accepted moderate social drinking and rarely called for total abstinence. They dealt more aggressively with the issue after the Revolution, but did not feature prominently in the temperance societies which sprang up in the antebellum period. The Philadelphia Association did call upon its members to abstain from all alcohol in 1830. That was the exception; many Baptists split over whether to give membership to wets. See Bill J. Leonard, Baptist Ways: A History (Valley Forge, PA: Judson Press, 2003), 221, 222.

149،Activity of the Church in Social Service,” Annual of the Northern Baptist Convention, 1909, $134,152$.

150“'Social Service Commission,” Annual of the Northern Baptist Convention, 1911, 130.
} 
the more conservative Baptists in West Virginia continued to support both causes for traditional reasons. The conservative and liberal approaches contained some key similarities. While they were not exactly the same in letter and spirit, both sides shared a desired goal. Elimination of alcohol and preservation of the Sabbath would strengthen the moral fiber of American civilization and build up the Kingdom.

Like the other two major Protestant groups, the Southern Presbyterian understanding of these issues flowed naturally from denominational distinctives and efforts to remain loyal to its faith tradition. Calls for temperance reform were extremely rare among Southern Presbyterians. The Southern General Assembly made no mention of temperance until 1914, when the body called upon members to vote for prohibition, but the Synod of Virginia, which still included West Virginia, objected to this action. While Virginia Presbyterians certainly favored temperance and viewed the liquor trade as evil, they objected to what they perceived as the church's endorsement of national prohibition laws, seeing such a declaration as a political act and therefore contrary to ecclesiastical rule and procedure. ${ }^{151}$

Read into the minutes the following year, this objection seemed to make an impact on the PCUS approach to drink. The national body issued its first (and only report prior to 1920) temperance report in 1915. It supported temperance and Prohibition, but offered no specific detail about how to achieve those ends. It simply called upon believers to use "legitimate means" to fight liquor and pernicious influence. ${ }^{152}$

\footnotetext{
${ }^{151}$ Minutes of the General Assembly of the Presbyterian Church in the United States of America, 1915, 29. By contrast, the Northern Presbyterian General Assembly had committees on temperance and Sabbath observance in 1890. See "Special Committee on Sabbath Observance," Minutes of the General Assembly of the Presbyterian Church in the United States of America, 1890, 65-68; "Standing Committee on Temperance," 80-84.

152،"Report on Temperance," Minutes of the General Assembly of the Presbyterian Church in the United States of America, 1915, 77.
} 
Local records reflected the pan-Virginian aversion to unified denominational political action against alcohol. Synods and presbyteries in Virginia and West Virginia had temperance committees. However, detailed reports were almost never included in presbytery or synodical minutes. These few reports demonstrated a nuanced interpretation of the doctrine of the spirituality of the church. In 1883, the Synod of Virginia issued a report on temperance which could be understood as a rejection of that foundational Presbyterian doctrine. It denounced intemperance as an evil which "undoubtedly keep[s] many persons from the throne of God." The committed called upon the synod to "exhort our members and people" to fight liquor using "all such means by legislation or otherwise as may otherwise seem to them most advisable."153

At first glance, this resolution seems almost identical to the objectionable one passed more than thirty years later by the General Assembly. However, as Southerners interpreted it, the doctrine of the spirituality of the church did not completely prevent them from discussing political involvement, as long as it was done carefully. The doctrine did state that the church was a distinctly spiritual entity and as such should refrain from "engaging in the broader cultural aspects" of society. However, individual Presbyterians working in the secular sphere were expected to let their faith guide and influence their actions. In this case, passing temperance legislation should be in accordance with an individual Presbyterian's personal beliefs. Furthermore, the church believed the civil government did in fact have a responsibility to legislate in certain areas, and the church was well within its proper bounds to remind the state of these duties. ${ }^{154}$

It appears, then, that the Synod did not intend its 1883 report to be a statement of official denominational support for political action. The 1884 on temperance indicated that while the

\footnotetext{
153،"Temperance," Minutes of the Synod of Virginia, 1883, n.p.

${ }^{154}$ Randall H. Balmer and John Fitzmier, The Presbyterians (Westport, CT: Praeger, 1994), 91; "Sabbath Observance By Railroads," Minutes of the Synod of Virginia, 1905, 91.
} 
synod maintained its position against direct political involvement by the church, it would not attempt to limit the action individual members might take. In 1913, it supported the General Assembly's stance on liquor, adopting the national body's resolution. Failure to oppose sin was itself a sin of omission, and thus Presbyterians must take action. However, the resolution remained vague in its declaration of action, stating only that, "we urge on all our membership the duty of using all legitimate means" and "all ways which may be approved by their Christian conscience and judgment." 155

The complete lack of temperance reports in the minutes of the Greenbrier, Lexington, and Winchester presbyteries could also suggest a strong commitment to the spirituality of the church. While the ministers and Sunday School teachers educated their parishioners and students about the evils of alcohol, the presbytery as a whole apparently felt no need to make official declarations on the subject. In 1915, this attitude carried over into the newly created Synod of West Virginia (PCUS), which refrained from issuing temperance reports through the 1920 s. $^{156}$

To Southern Presbyterians, Sabbath-keeping constituted a far greater concern than temperance. Even though calls for this reform were still not as frequent or vehement as Methodist calls for temperance, they nevertheless reflected the connection between morality and civilization and showed that Presbyterians, explicitly or implicitly, placed a substantial burden on the civil government to perform its duties. The General Assembly formed a Sabbath committee in 1878. The following year, the committee issued its first report. The statement was general and

\footnotetext{
155،The Liquor Traffic,” Minutes of the Synod of Virginia, 1913, 270.

${ }^{156}$ This did not prevent local churches from taking some action. The Davis Memorial Presbyterian Church in Elkins, for example, endorsed a Woman's Christian Temperance Union petition to Congress calling for a prohibition amendment to the Constitution. This, however, was the exception, not the rule. See Thomas Richard Ross, The Davis Memorial Presbyterian Church 1895-1995: A Century of Service (Parsons, WV: McClain Printing Company, 1995), 40.
} 
cautious in tone. It called upon all Presbyterians, especially pastors and other church leaders, to zealously defend the Sabbath. It urged synods and presbyteries to carefully consider the matter and take such action as they saw fit. ${ }^{157}$

In 1880, the Sabbath committee issued a lengthy report detailing the importance of Sunday. Just as the railroad prompted new missionary endeavors, it also prompted renewed concern for properly observing the Lord's Day. The committee applauded existing laws which limited individual activity on that day. However, it expressed concern that railroads and other corporations conducted business as they would the other six days of the week. The General Assembly condemned it as a double injustice. First, such trade violated God's command to keep the Sabbath holy. Second, the government, by allowing such activities, endorsed a double-standard. Somehow, activity that was illegal for individuals became legal when committed by corporations. The report pointed out that "God recognizes no such distinctions.",158

The document also argued that proper respect and observance of the Sabbath represented the key to the successes of Great Britain and then America. Restricting business and public affairs on Sunday symbolized the country's commitment to the biblical principles which undergirded the Constitution. Failure to do so constituted a crime against humanity, the earth, the church, and God. The committee called upon all ministers and other church leaders to zealously observe the Sabbath, as words without action were worthless. Other recommendations included forming new voluntary associations and cooperating with existing ones committed to the observance of the Lord's Day. The report also brought up the possibility of petitioning the state

\footnotetext{
157،"Report of the Special Committee on the Sabbath," Minutes of the General Assembly of the Presbyterian Church in the United States, 1879, 45, 46.

158“"First Report of the Permanent Committee on the Sabbath," Minutes of the General Assembly of the Presbyterian Church in the United States, 1880, 88, 89.
} 
government. The synods of Alabama and North Carolina had already done so, the latter with success. Such an option should be available to all synods if they chose to exercise it. ${ }^{159}$

The same report attempted to reconcile this position with the doctrine of the spirituality of the church, and in doing so offered a carefully constructed explanation of that position. The committee fully endorsed the spirituality of the church and the related concept of the separation of church and state. The church's rightful purview was religious and spiritual matters, but the Sabbath was not just a religious matter. It was a moral and temporal matter, and it was on this aspect of the issue that the church believed it had a right to address before secular authorities.

The health of the country rested in part upon Sabbath observance, and therefore the topic was the proper subject of legislative involvement. The government could not and should not compel people to worship on Sunday or any day. However, the government could and should compel people, whether they toiled in labor or management, to abstain from work one day a week. Good morals, which of course sprouted from religion, made a firm foundation for good government, which was necessary to maintain a strong and happy nation. ${ }^{160}$

The General Assembly itself, however, waited another fifteen years to issue a clear call for Lord's Day legislation. Records indicate there was much debate in the denomination about the effectiveness of government action. By 1895, doubts about proposing legislation disappeared, and the committee "commend[ed] all wise legislation for protection of the Sabbath." In addition to reiterating calls for more frequent sermons on the subject and for interdenominational cooperation, the General Assembly for the first time called upon individual

\footnotetext{
${ }^{159}$ "First Report of the Permanent Committee on the Sabbath," 89, 90.

160، The First Report of the Permanent Committee on the Sabbath," 89, 90. To be sure, it does seem that there was some inconsistency in the application of the spirituality of the church to the issues of temperance and Sabbath reform. That, however, is a topic well beyond the scope of this project. In any event, the evidence here indicates West Virginia Presbyterians did view both of these social issues through the lens of their traditional doctrine.
} 
church members to be more vigilant and strict about keeping the day holy. While the central body respected the right of individual conscience, it requested that congregants prayerfully consider their behavior. ${ }^{161}$

On a national level, the Southern Presbyterian church maintained this position through the 1920s. Apparently, all of the constituent synods were comfortable with the position on government action and church support for it. State and local bodies also experienced an evolution of their views on appropriate action in defense of the day of worship and rest. In 1880, the Synod of Virginia issued a call to the presbyteries, instructing them, if they had not already done so, to form committees on the Sabbath and formulate plans to halt desecration of the Lord's Day, but the directive contained no detail on what action should be taken. The report also expressed concern that "evangelical denominations" contributed in part to the erosion of respect for Sunday by participating in public gatherings and other social events on that day. ${ }^{162}$

The synod remained silent on the issue for the next quarter of a century, although their Sabbath committee still existed. In 1907 the synod formed a committee devoted especially to Sabbath observance in West Virginia, which had no laws regulating railroad use on Sundays. The board sent letters to the largest railroads operating in the state, as well as to Henry G. Davis and Stephen B. Elkins. Only Davis responded, but no details from his letter appear in denominational records or in his own personal papers. ${ }^{163}$ No other reports from this committee appear in

\footnotetext{
161،"The Report of the Standing Committee on the Sabbath," Minutes of the General Assembly of the Presbyterian Church in the United States, 1895, 427-429.

162،Sabbath Observance," Minutes of the Synod of Virginia, 1880, 355, 356.

163،"Sabbath Observance of Railroads in West Virginia," Minutes of the Synod of Virginia, 1907, 254. Another committed formed two years earlier to persuade Virginia railroads to abide by existing laws. They joined an interdenominational group comprised of the Virginia Conference of the ME Church, South, the Association of Baptist Churches, and the Diocese of Southern Virginia of the Protestant Episcopal Church. The group's primary target was the railroads themselves. When it was unable to convince them to voluntarily comply, the churches expressed a willingness to use the courts to force compliance, and perhaps even lobby the legislature for tougher statutes. The
} 
synodical proceedings. In fact, after 1908, Sabbath observance issues of any kind disappear from the records for more than a decade. The next report on Sabbath observance in West Virginia did not appear until the 1920s. In 1921 the Synod of West Virginia began cooperating with non-sectarian Sabbath reform organizations, such as the Lord's Day Alliance, in continued efforts to promote official pro-Sabbath legal and political action. ${ }^{164}$

Sabbath reports were more frequent in the records of the presbyteries, but still intermittent. They showed that Southern Presbyterians in West Virginia held the Sabbath in high regard and tried to scale back what they considered to be inappropriate behavior on Sunday. Some presbyteries issued more reports than others, and some contained more detail, but all agreed on the basics. As the Winchester Presbytery acknowledged, Sabbath obligations were binding on Christians, and the civil authorities had their role to play in ensuring the day was not profaned. ${ }^{165}$ Of course, Christians had to take responsibility for their actions, and thus refrain from breaking the Sabbath, even if they had gone to church in the morning. Ministers, therefore, needed to preach on the importance of the Sabbath more frequently. The Winchester Presbytery continually reiterated these calls for educating and exhorting parishioners. ${ }^{166}$

In 1880 the Lexington Presbytery petitioned the Virginia legislature to enact a law prohibiting unnecessary use of trains on the Sabbath. Such a law had already been passed in North

Presbyterians expressed concern about this legal route, citing the spirituality of the church. However, three years later, they participated at a meeting between the various denominations and the presidents of the major railways in Virginia. This meeting led to a proposed bill which would have eliminated excursions and reduced fares on Sunday, as well allowing freight trains carrying perishable goods to run for just four hours. The legislature defeated the bill. See "Sabbath Observance by Railroads," Minutes of the Synod of Virginia, 1905, 90, 91; "The Committee on Observance of the Sabbath by Railroads," Minutes of the Synod of Virginia, 1908, 303.

164“'Sabbath Observance Committee," Minutes of the Synod of West Virginia, 1921, 15.

165 "Report on the Sabbath," Minutes of the Winchester Presbytery, 1880, 65.

166“"Observance of the Sabbath," Minutes of the Winchester Presbytery, 1895, 38. 
and South Carolina. ${ }^{167}$ Railroad use was only one cause of Sabbath desecration. Fifteen years later, the Sabbath committee recognized a series of different threats, ones which the synod generally ignored. Participation in worldly pursuits such as baseball games, fairs, shopping, theater performances, and drinking also contributed to the decline in public morality and loss of respect for God's holy day. ${ }^{168}$ Decrying Sunday amusements as inappropriate use of time became a common theme running through Lexington Presbytery Sabbath reports.

Southern Presbyterians at all levels believed the spirituality of the church allowed them to make some call for government action to protect Sunday. However, such calls had to be carefully worded in order to emphasize the moral, not the religious, nature of the problem. Following the same logic, it would seem that Southern Presbyterians at all levels would be more willing to make similar statements and take similar actions on temperance. Various temperance organizations argued that alcohol represented a distinctly moral threat to families and societies, building a dry coalition that transcended sectarian differences. What prevented the Presbyterian Church in the United States from making the same argument? Based on the documentary evidence, it is unclear. It is clear, however, that the Sabbath constituted the more important issue and that Southern Presbyterians believed they were acting according to doctrinal standards in both cases. Achieving Reform

Looking at temperance and Sabbath-keeping together in these three denominations shows how churches saw their role in society. They were not just winning converts; they were bettering society as a whole by improving the condition of its constituents. This was not just the opinion

\footnotetext{
167،“Committee on Sabbath Observation,” Minutes of the Presbytery of Lexington, 1880, 42.

168“Sabbath Report," Minutes of the Presbytery of Lexington, 1895, 44. The Sabbath reports from the Greenbrier Presbytery were rather unremarkable. Of course, they denounced recreation and leisure activities on the Sabbath as sinful and encouraged members to refrain from such behavior, but they really do not add anything to the understanding of the Southern Presbyterian position on the issue.
} 
of supporters of the institutional church. As Handy observes, late Victorian culture saw a morally upright and self-restrained people as essential for economic progress. Attending church became a symbol of commitment to the moral and social framework of Christian America. ${ }^{169}$

However, these particular moral crusades could also be interpreted as signaling the decline of sacred authority in the mountains and the transfer of that authority and influence to secular vestiges, be they industry or civil government. As the Progressive Era matured and faded into the Roaring Twenties, some industries switched to five- or six-day work weeks on their own. While many still required seven days of labor from employees, some industrialists, such as Davis, attempted to minimize the number of workers needed on Sundays. Civil authorities did not require such largess; entrepreneurs, for a number of reasons, decided this practice made good business sense. However, capitalists stopped short of capitulating to Sabbatarian demands. The close ties between the businesses and religious denominations often translated into dependence of the sacred on the secular. Many industrialists were more than happy to support reform, whether voluntary or coerced, but only on their own terms. Enterprises such as transportation, utilities, or large-scale manufacturing wanted the freedom to do as they chose, while often calling upon civil government to enforce Sabbath restrictions on smaller firms. ${ }^{170}$ In the end, Victorian businessmen were businessmen first and Victorians second. Simply put, temperance laws usually suited their needs better than Sabbath laws.

Such modifications to the work week and the conditional nature of secular support could help explain the growing silence from mainline Protestants on Sabbath reform as the twentieth century progressed, although there were still some murmurs on Sunday's behalf. Unlike tem-

\footnotetext{
${ }^{169}$ Handy, 73.

${ }^{170}$ McCrossen, 146-151.
} 
perance, there were no reports of progress or victory in Sabbath reform in West Virginia. ${ }^{171}$ Even after state and federal constitutional prohibition amendments passed, Methodists, Baptists, and Presbyterians continued to urge the government to strictly and consistently enforce the law. However, requests that their preachers make conscious efforts to sermonize against alcohol became increasingly sporadic and in some cases ceased entirely.

Henry Gassaway Davis embodied the capitalist seeking to establish a culture in the mountains that sought to integrate Appalachia into mainstream America and establish hegemony over the existing pre-industrial culture and any other claimants to authority, including the church. He fully understood, though, that industry and religion must complement each other. In 1907 he wrote a letter to the Board of Church Extension of the West Virginia Methodist Protestant Church:

Church Extension and State development should go together. There is work to do, not only in the new communities that are springing in West Virginia, but in the older ones, where the people are unable from want of opportunity, to receive proper spiritual instruction. In your endeavors in this work you have my best wishes. ${ }^{172}$

In Gilded Age and Progressive Era America, Christianity played an important role in shaping society and culture. A Christian America needed a strong Christian (meaning Protestant) church; however, the failure of Sabbath reform and the success (at least temporarily) of temperance could suggest a critical merging of values and a shift in authority. Sacred and secular values coalesced to support a materially and spiritually prosperous America. As the two spheres came together, the secular emerged as superior to the sacred, as the former's ability to command resources grew exponentially. At the same time, the sacred became increasingly willing to sub-

\footnotetext{
${ }^{171}$ This does not imply that Sabbath reform efforts failed all over the nation.

172،"Board of Extension,” Minutes of the West Virginia Conference, Methodist Protestant Church, 1907, 25. This board was in charge of funding construction of church buildings and expanding existing structures to accommodate growth.
} 
ordinate itself to the secular. That latter sphere then became the final arbiter of values, deciding which remained legitimate and which did not. In this case, temperance continued to be useful while Sabbath observance did not.

The actions and attitudes of men such as H. G. Davis also demonstrated this transformation in American culture and society. He acted in ways that he believed were most beneficial to industry, and he made it clear that he would not tolerate any effort by religious groups against him, no matter how seemingly insignificant. When Father Charles Wieder, a local Roman Catholic priest, removed church funds from Davis's Bank of Piedmont, deposited them into "a new and opposition bank," and then encouraged his parishioners to do the same, Davis appealed directly to James Cardinal Gibbons, archbishop of Baltimore. The industrial leader noted that a number of Catholics worked in his mines and on his railroad and that "if the church representative works against us ... it could [not] well expect any friendly acts from us." ${ }^{\prime 73}$ Cardinal Gibbons replied, but his response was lost. Apparently Davis was satisfied with the resolution, as he never mentioned the incident again. This episode did not represent a distinct anti-Catholic sentiment. In his letter to Cardinal Gibbons, Davis notes that he did, from time to time, donate funds to the Catholic Church. Rather, it illustrated the fact that, in the new industrial order, when sacred and secular concerns conflict, the secular would take precedence.

At the same time, it demonstrated, along with so many other incidents, Davis's desire to support and work with religious organizations and sources of sacred authority. Due to the paucity of "people of means" within the state, he felt "called upon to do ... religious and charitable work in West Virginia," regardless of the denomination or specific religious affiliation of that work, although he gave most of his financial support to Presbyterian churches. While he and

\footnotetext{
${ }^{173}$ Letter from H.G. Davis to Cardinal James Gibbons [sic], April 2, 1888. Series 15, Box 206, Henry Gassaway Davis Papers, West Virginia Collection, Wise Library, West Virginia University, Morgantown, WV.
} 
many other capitalists in the mountain counties joined the Presbyterian church, they realized the necessity for a broader consensus in accomplishing the "civilizing" task. Through charitable giving to all Protestant groups, and at least occasionally to the Catholic Church, Davis in particular encouraged church growth and demonstrated an appreciation for basic Christian morality and the stability it could bring to society.

He and other members of the local elite supported the temperance cause in other important ways. Historian David Corbin surveyed some of the ways industrialists attempted to influence the culture of their workers, thus persuading them to give up the drink voluntarily. In the wake of the Paint Creek-Cabin Creek strike of 1912, coal operators funded the establishment of YMCAs across the southern tier of the state. Drinking in the region decreased fifty percent over the subsequent five years. ${ }^{174}$ H.G. Davis was well ahead of that trend. Writing to the president of the YMCA national board, Davis noted that he felt "obligated to devote what money I can consistently give for the advancement of this cause to the work in my own State."175 In 1906, the Young Men's Christian Association of Maryland, Delaware, West Virginia, and the District of Columbia recognized his dedication to the organization in West Virginia. During his keynote address to that regional body, he remarked that the YMCA "is doing such wonderful work in improving the moral and spiritual condition of the time."

Later that year he donated a lot for a YMCA building in Charleston. His daughter Hallie, wife of his business partner and U.S. Senator Stephen B. Elkins, donated land for and fully fund-

\footnotetext{
${ }^{174}$ David Corbin, Life, Work, and Rebellion in the Coal Fields (Chicago: University of Illinois Press, 1981), 124, 125.

${ }^{175}$ Letter from H.G. Davis to Francis A. White, Oct. 22, 1906. Series 15, Box 220, Henry Gassaway Davis Papers, West Virginia Collection, Wise Library, West Virginia University, Morgantown, WV.

${ }^{176}$ Henry Gassaway Davis, “Journal,” Jan. 26, 1906.
} 
ed the construction of a YMCA building in the town of Elkins. ${ }^{177}$ The local Presbyterian elite, many of whom were also the industrial and political elite, remained active in the YMCA. State Senator (and later Congressman) Howard Sutherland's wife became President of the YMCA Ladies Auxiliary in 1911. That same year, Presbyterian ruling elder and deacon Boyd Wees was elected YMCA Senate President, with H.G. Davis chosen as YMCA Board President. ${ }^{178}$ While there is no known correlation between the YMCA and alcohol consumption in and around Elkins, Davis, his family, and their allies cast themselves in the role of benefactors of all society while promoting a particular set of late Victorian values.

In addition to religious and cultural efforts, these men and women also used political means to reach their goals. For example, despite the fact that neither his church nor the presbytery to which it belonged made specific calls for temperance reform during his life time, Davis, as a private entrepreneur, wrote to all the magistrates in Randolph County asking that they deny liquor licenses for establishments along his train routes in the hopes of decreasing conflict in the camps and boosting productivity. ${ }^{179}$ When the state legislature voted on a prohibition amendment to the state constitution in 1911, three of Davis' associates and fellow Presbyterians represented the district containing Randolph County. In the Senate, Howard Sutherland voted dry. As Delegates, Davis' son John T. Davis and James W. Weir, both Presbyterians from Elkins, also voted against the drink. During a brief stint in Congress, Colonel Thomas B. Davis, a Presbyterian lay leader from Piedmont and brother of H.G. Davis, labored for greater federal control over

\footnotetext{
${ }^{177}$ H.G..D., “Journal,” May 25, Dec. 6, 1906.

178،"Ladies Auxiliary,” Elkins Inter-Mountain, Jan. 12, 1911; “Y.M.C.A. Senate Organized on Thursday Night,” Jan. 13, 1911; "Y.M.C.A. Board of Directors for Coming Year," Feb. 6, 1911.

${ }^{179}$ Alan Clarke, West Virginia's Coal and Coke Railway (Lynchburg, VA: TLC Publishing, 2002), 15.
} 
liquor. ${ }^{180}$ By acting in secular capacities as elected public officials, these men voted in accordance with Presbyterian doctrine and their own personal beliefs. While the church itself refused to petition civil government in favor of Prohibition, it did encourage and expect its members to strive for righteous laws in all areas. ${ }^{181}$

Biblical teachings and morality were driving factors for sectarian and non-sectarian drys alike. Historian Richard Hamm notes that prohibitionists in particular, and progressive reformers in general, held an Old Testament conception of the legal system which equated law with morality. The idea that the government had a responsibility and a duty to promote morality for the common good and general welfare of all society was foundational to the progressivism of the early twentieth century. As Hamm writes, "Since no one had a right to make others suffer by offering them temptations to sin, the government needed to command the end to such temptations." 182

Such suffering was widespread, and many, especially women, recognized that those who suffered the greatest were not the ones doing most of the drinking. Women and children, with relatively little legal protection against the misconduct of husbands and fathers in the nineteenth century, often found themselves at the mercy of men who, in lieu of rent, heat, and food, spent what money the family had at the local pub and then staggering home to assault their wives and children. “Given a woman's limited legal rights, the drunkard as head of the household was seen

\footnotetext{
180“First Prohibition Amendment Vote in House: 73 For to 9 Against," Elkins Inter-Mountain, Feb. 3, 1911; "Prohibition Amendment Goes Through Upper House by Vote of 23 to 7," Elkins Inter-Mountain, Feb. 7, 1911; Letter from West Virginia Anti-Saloon League to Thomas B. Davis, Feb. 1907. Thomas B. Davis Papers, West Virginia Collection, Wise Library, West Virginia University, Morgantown, West Virginia.

181،'Sabbath Observance By Railroads,” Minutes of the Synod of Virginia, 1905, 91.

${ }^{182}$ Richard F. Hamm, Shaping the $18^{\text {th }}$ Amendment: Temperance Reform, Legal Reform, and the Polity, 1880-1920 (Chapel Hill: The University of North Carolina Press, 1995), 34-37.
} 
as a true oppressor of his wife and family," observes scholar Ruth Bordin. ${ }^{183}$ In fact Eliza Thompson, the first president of the Women's Christian Temperance Union, saw the effects of strong drink first-hand. Alcohol abuse contributed to her son Allen's early death. The family also experienced serious financial problems stemming from her husband's drinking problems. ${ }^{184}$

The Woman's Christian Temperance Union and the Anti-Saloon League in the mountains of West Virginia shared these opinions of morality and the adverse effects of alcohol on the home and family. These organizations worked to rally the people in favor of prohibition and to elect men such as Sutherland, Davis, and Weir. In 1910, the year before the legislature voted on the prohibition amendment, Mineral County had no county W.C.T.U. chapter, and the Keyser chapter had just been reorganized. The Piedmont chapter, which had been very active in the 1880s and 1890s, had folded. Grant County had two local chapters; Tucker County had three, two of which were newly-established. Elkins housed the only chapter in Randolph County, and Pocahontas County had two chapters, one in the logging town of Cass. ${ }^{185}$

Through at least the mid-1910s, ten local chapters of the Anti-Saloon League existed along the West Virginia Central and Pittsburg mainline. With twenty members, Elkins had the largest organization by far, followed by Marlinton and Davis, the only one in Tucker County,

\footnotetext{
${ }^{183}$ Ruth Bordin, Women and Temperance: The Quest for Power and Liberty, 1873-1900 (New Brunswick: Rutgers University Press, 1990), 6, 7.

${ }^{184}$ Holly Berkley Fletcher, Gender and the American Temperance Movement of the Nineteenth Century (New York: Routledge, 2008), 83-85.

${ }^{185}$ Minutes of Twenty-Eighth Annual Convention of the Woman's Christian Temperance Union of West Virginia, 1910 , $34,35,38,108,113-115$. Over the course of the 1910s, the number of local chapters in the mountain counties fluctuated significantly. Some chapters, such as those in Davis and Elkins, remained relatively strong, while others such as Thomas and Hendricks, which were newer, faded. See Minutes of the Thirty-Fifth Annual Convention of the Woman's Christian Temperance Union of West Virginia, 1917, 16-19, 74, 75.
} 
with six men each. Randolph County had another chapter, and Pocahontas County had four additional groups. Grant and Mineral Counties each had one, with one member each. ${ }^{186}$

Neither the WCTU or the Anti-Saloon League claimed overwhelming numbers, and, at best, most chapters could be called semi-active. Furthermore, no details remain about their exact work in the communities along the railroad. However, business and religious leaders, clerical and lay, featured prominently in these organizations at the local level. In Elkins, Presbyterians contributed significantly to both groups. Elders and deacons from the Davis Memorial Presbyterian Church, most of whom came from the ranks of the secular elite, comprised more than one-third of the local Anti-Saloon League. In 1900, the wives of Presbyterian elders served as president and corresponding secretary of the Elkins chapter of the W.C.T.U. The treasurer was the mother of a deacon. ${ }^{187}$

Members of other denominations became involved in both organizations, demonstrating a cultural as well as a religious unity among Protestants. The president of the Hambleton W.C.T.U. was the wife of a Baptist pastor. A member of the Davis Methodist Episcopal Church served as treasurer of the Randolph-Tucker Bi-County W.C.T.U. and another Methodist laywoman acted as treasurer of the Davis chapter; the wife of a lumber dealer and Methodist trustee served as president of that group. ${ }^{188}$

\footnotetext{
186، Anti-Saloon League of West Virginia.” Typescript Membership List, n.d. Located in the West Virginia Collection at the Wise Library of West Virginia University, Morgantown, West Virginia.

187“"Anti-Saloon League of West Virginia.”; Minutes of the Eighteenth Annual Convention of the Woman's Christian Temperance Union of West Virginia, 1900, 78; Thomas Richard Ross, The Davis Memorial Presbyterian Church 1895-1995: A Century of Service (Parsons, WV: McClain Printing Company, 1995), 124-128; Twelfth Census of the United States, 1900; Thirteenth Census of the United States, 1910. Clergy from the major Protestant denominations of West Virginia occupied all state-level offices. See Letter from West Virginia Anti-Saloon League to Thomas B. Davis, Feb. 1907.

${ }^{188}$ Minutes of the Twenty-Eight Annual Meeting of the Woman's Christian Temperance Union of West Virginia, 1910, 114, 115; Thirteenth Census of the United States, 1910.
} 
Methodists were also very active in the Anti-Saloon League. Five of the six members of the Davis chapter were Methodists - the pastor of the ME South, Church and the pastor and two trustees from the Methodist Episcopal congregation. Not to be outdone, the entire membership of the Marlinton Anti-Saloon League, six people in all, consisted of clerical and lay leaders of the ME Church, South. In addition to the pastor, members included the treasurer, stewards, and trustees. $^{189}$

The notable presence of Methodists in the temperance movement is not surprising. Lack of church records prevents identification of the religious affiliation of the rest of the Elkins AntiSaloon league, but it is possible that Methodists were active in that local chapter as well. Sectarian diversity also reflected social diversity in the temperance movement. The Elkins Presbyterians predominantly hailed from the upper class; they were political and business leaders. One of the Methodists from Davis was a lawyer, but the rest of the Davis and Marlinton temperance activists worked as salesmen and clerks - members of the commercial middle class.

From the available records, it seems the working class displayed comparatively little interest in actively campaigning for prohibition, but the upper and middle class men and women steering the dry movement in the mountains needed the support of the lower class. As the vote on the state prohibition amendment neared, anti-liquor efforts focused on those groups most likely to vote wet. A month before the 1912 plebiscite, the West Virginia Lumberman's Association held a prohibition rally, with an estimated 3,000 people attending. All of the lumber companies in the county gave their workers the day off, and trains transported them into the city from all over the county. Not surprisingly, the press coverage of the event did not discuss temperance

\footnotetext{
${ }^{189}$ Pearle G. Mott, History of Methodism in Davis, West Virginia (n.p., 1965), 24, 25, 61; “Anti-Saloon League of West Virginia"; "Quarterly Conference Roll," Marlinton Charge of the Methodist Episcopal Church, 1915-1922; Thirteenth Census of the United States, 1910; Fourteenth Census of the United States, 1914
} 
enthusiasm among timber workers. There might not have been much to talk about there, but the employees did enjoy a day of free food and games. ${ }^{190}$

In Pocahontas County, the only county in the state with more timber workers than Randolph County, the press attempted to win over targeted groups. During the months leading up to the vote, The Pocahontas County Times ran a brief column every week containing protemperance quotes from labor and Catholic leaders. The section was clearly aimed at industrial workers and immigrants, who were often one and the same. Rather than appeal to middle or upper class conceptions of virtue, respectability, or morality, the paper wanted to show working men that staying dry was in their best interests. The selected excerpts suggested that labor unions could maximize their strength and reach their full potential only if their members shunned alcohol. $^{191}$

Based on the result of the 1888 prohibition amendment vote, these and similar campaigns appeared desperately needed. Precinct-by-precinct returns from that election are hard to find. The Wheeling Intelligencer reported the following approximate returns for the mountain counties: 369 votes against the amendment in Grant, 700 against in Mineral, 483 against in Pocahontas, 1,408 against in Randolph, and 500 against in Tucker. However, the paper mentioned nothing about the number of people supporting prohibition. The Tucker Democrat reported no figures, but stated, "The Prohibition Amendment was defeated by a large majority in this County." The Freeman reported that the amendment failed in Randolph by a vote of 1,661 to $253 .{ }^{192}$

\footnotetext{
190،‘3,000 Lumbermen Attend Prohibition Rally In Elkins Last Saturday,” The Daily Inter-Mountain (Elkins, WV), Oct. $14,1912,1,2$.

191،"The Working Man and the Saloon,” The Pocahontas Times (Marlinton, WV), Aug. 29, $1912,1$.

192،The Prohibition Amendment Majorities," The Wheeling Intelligencer (Wheeling, WV), Nov. 26, 1888, 1; "Prohibition and Amendment Vote," The Freeman (Parkersburg, WV), Nov. 14, 1888; The Tucker Democrat, Supplement (Parsons, WV), Nov. 9, 1888, n. page.
} 
Based on the results of the 1912 vote, dry campaigns both secular and sacred finally appeared to be successful. The five mountain counties voted overwhelmingly for the prohibition amendment. In Tucker County, the vote was 1,908 in favor to 854 against. All but one district in Mineral County went dry by significant margins. Ironically, it was the Piedmont district, the original capital of the Davis industrial empire, that voted against the amendment, albeit by a slim margin. The Elk and Cabin Run districts, both of which were coal mining areas, voted dry more than two-to-one and three-to-one respectively. ${ }^{193}$

The rest of the mountain counties sent similar returns. Grant County supported the amendment by more than a two-to-one margin, with only one town dissenting. The industrial towns along the WVC\&P, all of which existed because of the railroad, favored outlawing liquor by more than three-to-one. The older towns in the central and eastern parts of the county also strongly supported prohibition. In Randolph County, the largest and most populous of the mountain counties, prohibition also enjoyed overwhelming support: thirty-five of thirty-six districts voted dry. In both the older agricultural communities and the newer industrial towns, alcohol suffered humiliating defeat. The end result was the same in commercial centers such as Elkins and mining and lumber towns such as Mill Creek and Alpena, although there were a few districts where the margin of victory was smaller. Harding, the one town that voted wet, was a mining town along a Davis railroad, but it was the exception, not the rule. It seemed, at least to some degree, that industrial workers actually supported temperance, or at least did not object to it enough to come out and vote wet. ${ }^{194}$

\footnotetext{
193،"The Vote in Tucker County," The Tucker Democrat (Parsons, WV), Nov. 31, 1912, 1; "Vote on the Amendment," Mineral Daily News (Keyser, WV), Nov. 8, 1912, 2.

194،“Official Vote of Grant County,” The Grant County Press (Petersburg, WV), Nov. 12, 1912, 2. Contrast this with the situation in Roanoke, Virginia, where parts of the working class were militantly pro-alcohol and, upon passage of dry laws, took out their frustration on those they believed to be responsible. Unlike in the Allegheny highlands of West Virginia, where temperance apparently created no great animosity between classes, in the Blue Ridge of
} 
The results from Pocahontas County seemed to verify that conclusion. The major lumber town of Cass went four-to-one for the amendment. Durbin, a mill community at the junction of the C\&O’s Greenbrier Division and H.G. Davis’s Coal and Iron Railway, favored prohibition three-to-one. Huntersville, the old county seat, and Marlinton, the new seat, both fell solidly into the dry column. Only two towns did not agree to the amendment. The people of the small farming community of Dunmore split on the issue, 32-32. Millpoint, a lumber center along the Greenbrier Division, rejected the amendment by more than forty votes. ${ }^{195}$

Overwhelming support for Prohibition did not represent overwhelming voter turn-out. In the mountain counties, roughly fifty-five percent of the voting population cast a vote on the issue. This was nominally lower than the percentage of ballots cast for president. ${ }^{196}$ Of course, some towns and districts had higher voter turn-outs than others. The lack of a large immigrant population in those counties could help explain the lack of a strong wet coalition. Foreign-born residents and those of mixed parentage comprised twenty-three percent of the population of Tucker County in 1910. However, that number did not exceed fifteen percent in any of the other four counties, and in Grant and Pocahontas counties it was under ten percent. While it is impossible to determine exactly who voted for or against prohibition in 1912, all of these statistics suggest that some contingent of the working class did go dry, in addition to traditional dry stalwarts of the middle and upper classes. In overwhelming rural counties, almost all of the mining

\footnotetext{
Virginia the issue exacerbated class and racial tensions. See Rand Dotson, Roanoke Virginia, 1882-1912: Magic City of the New South (Knoxville: The University of Tennessee Press, 2007), 121-161.

195“Election Returns," The Pocahontas Times (Marlinton, WV), Nov. 7, 1912, 1.

${ }^{196}$ Thirteenth Census of the United States, 1910: Population, Vol. 3 (Washington: Government Printing Office, 1913), 1019, 1021, 1022, 1035, 1037, 1039.
} 
and lumber communities supported the amendment, as did virtually all of the larger towns and county seats. ${ }^{197}$

It is beyond the scope of the present purposes to consider exactly how this coalition was formed. While that is certainly important, perhaps more germane is what the success of prohibition represented. In counties which usually oscillated between parties, the success of prohibition reflected a growing national trend, at least in locations with two viable political parties, of putting cause above party. In West Virginia, between 1888 and 1912, Democratic support for that cause skyrocketed, jumping from eleven percent to sixty-nine percent. Republican support dropped nominally from thirty-nine percent to thirty-five percent. ${ }^{198}$ While the mountain counties often leaned Democratic in national elections, they frequently elected Republicans to state and national offices. The temperance presence in the mountain counties, including the election of Republican officials who voted for the amendment in the state legislature, suggested a cultural unity that overcame political rivalries and stemmed from several different sources. The Davis crowd, symbolizing Victorian virtues of self-restraint and hard work, saw alcohol consumption as antithetical to these values, which they maintained allowed men such as Davis to rise up from obscurity to great wealth and fame. If left unchecked, alcohol "threatened to impede the region's economic and moral progress." 199

\footnotetext{
${ }^{197}$ Thirteenth Census of the United States, 1910: Population, Vol. 3, 1034, 1036, 1038. In 1910, the moniker "urban" denoted an incorporated entity with a population of at least 2,500 people. See Vol. 3, 1011.

${ }^{198}$ Ann-Marie E. Szymanski, Pathways to Prohibition: Radicals, Moderates, and Social Movement Outcomes (Durham, NC: Duke University Press, 2003), 141, 142.

${ }^{199}$ Bruce E. Stewart, Moonshiners and Prohibitionists: The Battle over Alcohol in Southern Appalachia (Lexington: The University of Kentucky Press, 2011), 122, 123. See also Ronald L. Lewis, Transforming the Appalachian Countryside: Railroads, Deforestation, and Social Change in West Virginia, 1880-1920 (Chapel Hill: The University of North Carolina Press, 1998), 165-209.
} 
Mainline Protestant denominations echoed this basic sentiment, while at the same time interpreting the issue through a biblical lens. In his study on prohibition during this period in western North Carolina, Bruce E. Stewart notes that attitudes toward alcohol began to change before the arrival of most missionaries in the 1890s. Local religious groups began to speak formally and publically against the drink as early as the 1870 s. $^{200}$ As shown, Protestants in West Virginia did the same, albeit a little later. However, unlike their North Carolina counterparts, Protestants in the highest elevations of West Virginia did not have the aid of Northern missionaries. Mainline Protestant morality in West Virginia mirrored that of industrialists and of other Protestants, but it was not intellectually or spiritually dependent upon these outside forces.

While the impact of the churches on the dry triumph should not be overstated, the fact that mainline believers in the state developed a strong anti-drink attitude independent of outside influences indicated important cultural connections between the state and the rest of the country. Those values also bound sacred and secular, and the common vocabulary allowed each to appeal to a wide spectrum of political, economic, social, cultural, and religious rationales to oppose alcohol. This fact, however, meant the lines between secular and sacred continue to blur, which in turn created the conditions for one to have greater influence than the other while at the same time employing the rhetoric of the subordinate group. The triumph of temperance reform and the failure of Sabbath reform showed that secular forces, particularly business interests, wielded increasingly greater power in American society vis-à-vis sacred authorities, particularly the Protestant church.

The passage of the amendment and the culture it represented by no means signaled the end of liquor in the mountains. Even after the statewide temperance triumph, bootlegging continued seemingly unabated in the eastern portion of Randolph County and southeastern part of ${ }^{200}$ Stewart, 123, 180, 181. 
Tucker County, both of which had restricted "demon run" via local option before 1912. Similar incidents occurred in several of the more remote areas of West Virginia. County Prosecutor, Anti-Saloon League and Presbyterian church member Herman Guy Kump received letter after letter from concerned citizens and business leaders in the very timber towns which at the ballot box had seemed so dry. The twin cities of Whitmer and Horton in Randolph County seemed particularly plagued by illicit alcohol. With a number of mills and lumber camps, these communities made prime targets for bootleggers. In fact, timber production suffered when court was in session because large numbers of camp foremen were called to testify before the Grand Jury in bootlegging cases. ${ }^{201}$

The situation got so serious that the people of Whitmer asked Kump to supervise the town election in 1913, believing his presence would prevent wet men from causing trouble. ${ }^{202}$ Due to a prior engagement, Kump could not go, but in his response to community leaders, he noted that legally there was nothing he could do that the local Justice of the Peace could not do. He argued that the people of the town did not really seem to care about the issue. Apparently they frequently refused to furnish evidence to local law enforcement, and there was even some suspicion that local law men were, in fact, part of the problem. ${ }^{203}$

Kump probably hit the nail on the head with this observation. With no help forthcoming, locals took matters into their own hands. In February 1913, the M.E. Church held a five-week revival which, according to the newspaper, "brought about a great change in our little lumbering

\footnotetext{
${ }^{201}$ Letter from J.H. Babb to H.G. Kump, Oct 6, 1911. Series 1 Box 5, Folder 38 of the Herman Guy Kump Papers, West Virginia Collection, Wise Library, West Virginia University, Morgantown, WV. Letter from J.H. Babb, Nov. 26, 1912. Series 1, Box 7, Folder 39.

${ }^{202}$ Letter from G.E. Bond to H.G. Kump, Dec. 26, 1912. Series 1, Box 7, Folder 40 of the Herman Guy Kump Papers, West Virginia Collection, Wise Library, West Virginia University, Morgantown, WV.

${ }^{203}$ Letter from H.G. Kump to G.E Bond, Dec. 28, 1912. Letter from H.G. Kump to Thomas B. Crittendon, Dec. 30, 1912. Series 1, Box 8, Folder 40.
} 
town." One of several such gatherings around election time, this one resulted in 280 conversions, many of them apparently of those who had been causing so much trouble. That summer, another church held a revival at which those in attendance decided that municipal authorities would take no action "of vital importance" unless first approved by local church members. The resolution was delivered to the council at its next meeting, at which time they complied, closing a dancing hall and refusing to grant a license to a would-be merry-go-round operator. ${ }^{204}$

These incidents demonstrate the close connection between the civil and religious aspects of temperance; they also suggest that even in new industrial mountain communities, people of all classes came to view alcohol as antithetical to the kind of society they were trying to build. Nevertheless, despite temperance supporters gaining the upper-hand in local politics, bootleggers continued to plague those areas of Randolph and Tucker counties on and off into World War I. ${ }^{205}$ The continuing struggle over alcohol, despite its decisive political defeat and continued dry action, reflected the cultural realities in the Allegheny region. The concept of Christian Civilization made great progress. Churches, mills, mines, and numerous other industries sprang up in the mountains and valleys. Railroads connected one of the most remote parts of West Virginia to the rest of America. Nevertheless, counter elements remained, and while for a time they posed no serious threat to the new order, they represented the gulf between the dominant consensus and alternatives.

\section{Conclusion}

\footnotetext{
204،"Breezy News from Whitmer-Horton,” Randolph Enterprise (Elkins, WV), Feb. 13, 1913; "Whitmer Church People Have Priority Over Town Council," Randolph Enterprise (Elkins, WV), July 24, 1913; Don Teter, Goin' Up Gandy: A History of the Fry Fork Region of Randolph and Tucker Counties West Virginia (Parson, WV: McClain Printing Company, 1977), 4.

205،'Bootleggers,” The Grant County Press (Petersburg, WV), March 16, 1917.
} 
Methodist scholars Russell Richey, Kenneth Rowe, and Jean Miller Schmidt contend that prohibition represented "the high water mark of Methodist national influence." 206 In an important way, perhaps prohibition also represented the high water mark of Protestant national influence. For more than a decade, a Protestant moral absolute became the law of the land, temporarily enthroned in the U.S. Constitution. In West Virginia, that reign lasted even longer. To what extent, exactly, were Methodists and other Protestants influencing society and in what ways were secular elites co-opting that message to promote their own ends?

Temperance and Sabbath observance are just two issues in a cluster of factors relevant to the matter, but those two issues do shed light on crucial features of that question. Between 1880 and 1920, church growth exploded in the mountains. Methodists, Baptists, and Presbyterians all produced numerous converts and established dozens of new churches. Undoubtedly, their social and cultural influence expanded as well. The new industrial elite also had considerable influence. Not only did it dominate the new economic system as well as the political system, but it also exerted control in religion. The work of Henry Gassaway Davis and his elite associates served as an example of how unity between the sacred and secular emerged. The discourses of “Christian Civilization” and industrial capitalism became virtually identical. ${ }^{207}$

Historian Alan Trachtenberg observed that the multi-faceted tumult of the Gilded Age was also a cultural struggle over the very meaning of America. Different groups fought "over the political and cultural authority to define the term and thus to say what reality was and ought to be."208 Progress was the spirit of the age. Business and religious leaders had long seen a con-

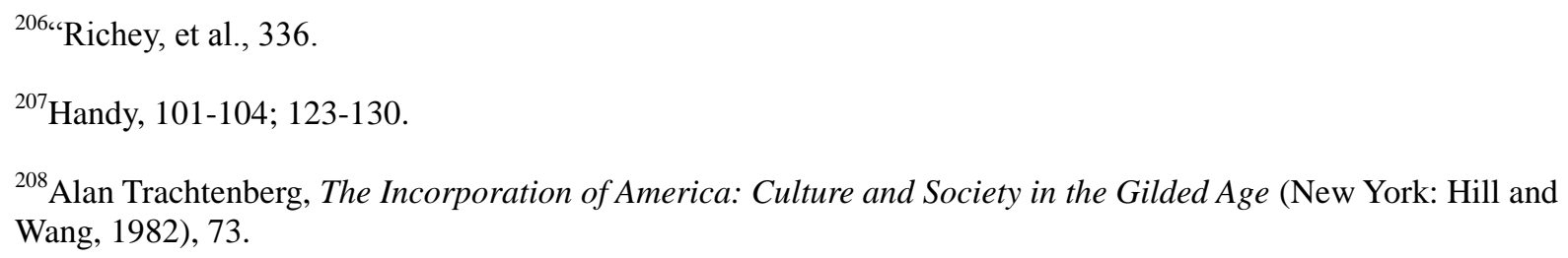


nection between moral and economic progress, but the Gilded Age witnessed a unique cultural merger of the two. These common beliefs congealed into a type of civil religion, a "quasireligious secular faith" which employed portions of religious traditions as symbols of national unity behind a common goal. Davis and his allies employed these masterfully. During the late nineteenth and early twentieth centuries, this common goal was an industrial and moral America, leading the world in temporal and spiritual progress and teaching other nations to follow in its steps. $^{209}$

During the Gilded Age and Progressive Era, industrial capitalists wanted to bring West Virginia into the mainstream of American culture - the state would help fuel the economic, and by extension, moral growth of the nation. They brought new technologies, started new industries, founded new towns, and challenged existing power structures. They radically changed the state, especially the most mountainous regions. Not everything was foreign and new. There were moral issues that capitalists shared with Christians all over the country, including those in the mountains of West Virginia. The fact that a significant part of industrial culture did not oppose the prevailing religious culture meant that West Virginia churches played an important role in incorporating the state into mainstream America. Many Christian values in the mountains were also middle-class Victorian values. The "Christian Civilization" both groups desired was based on the idea of "guaranteed freedom through the social behavior of obedience to recognized authority."210

\footnotetext{
${ }^{209}$ Charles W. Calhoun, "Civil Religion and the Gilded Age Presidency: The Case of Benjamin Harrison," Presidential Studies Quarterly 23 (Fall, 1993), 651-654. See also Jackson Lears, Rebirth of a Nation (New York: Harper, 1999) and No Place of Grace (Chicago: The University of Chicago Press, 1994); Hennen, 135, 149.

${ }^{210}$ Hennen, 149.
} 
As industrialization progressed, the "recognized authority" became increasingly secular. Church influence declined over a period of approximately forty years, as government and business became increasingly powerful. This occurred because sacred rhetoric fit so nicely with secular goals. When the ends did not coincide, as in the case of Sabbath-reform, it became clear which source of authority had more clout.

This process could not have occurred unless there were some fundamental and substantial religious similarities between Appalachia and the rest of the country - similarities revealing Appalachia to be very much a part of the nation rather than merely an appendix. Both Presbyterians and Methodists, by speaking to all members of society and allowing even the lowest to have some control over their own spiritual affairs, showed how churches could maximize the autonomy of the contracting sacred sphere, even as they could not and did not resist the secular culture which co-opted religious discourse. Speaking to all members of society meant speaking to the elite, too, and it was the scope of the message that aided the merger of secular and sacred. The co-opting took place precisely because secular leaders could occupy positions of leadership within the church as well. It was not all a façade; men such as Davis and Elkins most likely held sincere religious convictions, including views on temperance. The emergence and triumph of the idea of "Christian Civilization" in the Allegheny country revealed the role that organized religious groups and traditional American Christian morality played in industrialization. The mainstream Protestant churches could bolster secular power relations as they simultaneously gave a voice to the subordinate within those relations. 


\section{9: Comparisons and Conclusions}

"Then saith he unto his disciples, The harvest truly is plenteous, but the laborers are few; Pray ye therefore the Lord of the harvest, that he will send forth laborers into his harvest." According to the Gospel of Matthew 9:38 (Authorized Version), Jesus spoke these words to the disciples while preaching and healing throughout Galilee. The beginning of the next chapter finds Jesus empowering the Twelve to cast out demons and heal the sick. He then sent them out to tell the children of Israel that the kingdom was at hand (Matthew 10:1-5).

Jesus frequently used agricultural metaphors. He stressed the importance of telling the Jews about the next phase of God's plan for them. Throughout the centuries, Christians have understood this verse to teach the importance of mission work and evangelism. In short, people need to hear the gospel and God calls believers to spread that message. This concept is central to the Christian faith. Mainline Protestants in West Virginia certainly saw it that way, and rushed to build their denominations as the railroad opened up remote mountain regions.

Considered in another light, this verse could be applied to the development of faith as well. Politicians and businessmen throughout the state saw its natural resources as the driving force behind an industrial economy. West Virginia contained considerable amounts of coal, timber, and oil. Men were needed to invest the time, money, and effort required to command armies of men who would do the digging, cutting, shoveling, and hauling.

Harvesting souls built the kingdom of God; harvesting natural resources built the state of West Virginia. Both required faith - faith in a cause greater than the individual; faith in the righteousness of that cause; faith that hard work would be rewarded; faith that the means would be sufficient to bring about the desired end. Neither would let mountains stand in their ways. The development faith and the Christian faith worked together in particular ways during the 
Gilded Age and Progressive Era to build a "Christian Civilization" in America. Equating or conflating the cause of Christ and the cause of America was nothing new. In some sense, that idea is as old as the country itself. This way of life meant the old relationship between sacred and secular would be reconfigured. The new joining of the two produced a closer bond, but the resultant union was also perhaps more unequal.

An increasingly secular understanding of society prevailed, with progress being measured more in material than in moral terms. While the moral aspect certainly remained, secular forces exercised greater control in determining the legitimacy and usefulness of such values. This helped weaken the bond between morality and religion. To be clear, that bond very much still existed, and as Chapter 8 demonstrates, mainline Protestants certainly still saw themselves as a moral force in America. Many industrialists were themselves mainline Protestants, but it was in their capacity as entrepreneurs that they primarily exerted influence on society.

At the same time, it was this industrial connection with religion that facilitated cooperation between various denominations and big business. This continued to weaken the association between religion and morality, enabling secular forces to use the language of the sacred for distinctly secular purposes while still fostering alliances with churches. As shown in Chapter 7, this relationship helped produce renewed efforts at moral reform between 1880 and 1920. Churches found powerful allies in large corporations, but often the two worked at cross-purposes. Lack of support by businessmen put a reform effort at a distinct disadvantage. Across West Virginia, industrialists and Protestants groups alike supported temperance: reformers succeeded in passing temperance legislation and a prohibition amendment to the state constitution well before the passage of the Eighteenth Amendment to the federal constitution. Sabbath reform, which had succeeded in other states, made little progress in West Virginia. Some capitalists minimized busi- 
ness on Sundays, but took action on their own volition, not from government coercion. The alternating cooperation and conflict between religious and business mirror major manifestations of progressivism in the South and tensions within southern evangelicalism in general, with secular and sacred forces united on the quest for moral and material progress but differing at times on exactly how to achieve those goals. ${ }^{211}$

On an even larger scale, the sacred/secular relationship embodied in reform efforts helped connect the Allegheny region of West Virginia and the state as a whole to mainstream contemporary America. As Chapter 2 demonstrates even the most remote counties of West Virginia tried to participate in the national economy prior to industrialization. A pre-industrial agrarian society with the different patterns of work and elements of a barter economy still sought to utilize natural resources to generate cash and engage in regional and national commerce. Railroads revolutionized the area by making large-scale natural resource industries possible and profitable. They simply enabled long-time mountain residents and newcomers to maximize the use of resources. This transition required greater emphasis on efficiency, order, and authority. ${ }^{212}$

This could help explain why most of the major industrialists in the Allegheny region were Presbyterians. But mainline Methodists and Baptists offered no major opposition to industrialization either. As Chapters 4-6 show, all three of largest Protestant denominations in the mountains shared similar visions for their state and for the nation. Each saw industrialization and a

\footnotetext{
${ }^{211}$ Dewey W. Grantham, “The Contours of Southern Progressivism," The American Historical Review 86, no. 5 (Dec. 1981) : 1036-1040; William A. Link, The Paradox of Southern Progressivism, 1880-1930 (Chapel Hill: University of North Carolina Press, 1992), 37-57; Wayne Flint, "One in the Spirit, Many in the Flesh: Southern Evangelicals," in Varieties of Southern Evangelicalism, ed. David E. Harrell, Jr. (Macon: Mercer University Press, 1981), 33-44. See also William A. Link and Richard L. McCormick, Progressivism (Arlington Heights, IL: Harlan Davidson, Inc., 1983). Perhaps the two most notable differences between progressivism in West Virginia and the old Confederacy were the power of the Republican Party and the lack of black disenfranchisement in West Virginia.

${ }^{212}$ H.W. Brands, American Colossus: The Triumph of Capitalism, 1865-1900 (New York: Random House, 2010), 2225.
} 
closer bond with the rest of the country as a positive thing. The Christian faith remained most important to them, but they too came to support the development faith.

A point-by-point, belief-by-belief comparison of these denominations in the mountains at this time is difficult and unnecessary, at least for these present purposes. Each dealt with the changes brought by industrialization in different ways. These responses stemmed from unique aspects of the denominations and their specific situations in West Virginia at that time. The story of the relationship between religion and industrialization is, in one sense, a series of stories. At the same time, however, there are unifying themes running through those narratives. These commonalities help show the place of religion in American public life in the late nineteenth and early twentieth centuries.

Studies of Appalachian religion which focus on those denominations unique to the region - the mountain churches - can obscure the complexity of the role religion played in American life. To be sure, those studies highlight the constant power struggles in industrializing regions and how religion was used as both a means of resistance and control. United, Old Regular, and Primitive Baptists, as well as independent holiness churches, may have been unique to the mountains. $^{213}$ The research presented here, however, tells another story. The conclusions about "mountain churches" are not necessarily incorrect, but they do not encompass all there is to say about religion in Appalachia and its relation to industrialization. These small groups were by no means the majority in Appalachia even prior to industrialization. In places such as the Alleghenies, they hardly even existed, and certainly constituted no great religious, social, or cultural force, especially after the arrival of the railroad.

${ }^{213}$ Bill J. Leonard, “Introduction,” in Christianity in Appalachia: Profiles in Regional Pluralism, Bill J. Leonard, ed. (Knoxville: University of Tennessee Press, 1999), xvii. 
Mainline Methodists, Baptists, and Presbyterians overwhelmingly dominated the religious landscape of the mountains. Equally as important, they pre-dated the emergence of “mountain churches," sometimes by several decades. Throughout the nineteenth century, West Virginia members of those denominations fellowshipped and cooperated with their coreligionists in neighboring states. Some differences in practice and doctrine existed, but mainline Protestantism in West Virginia was remarkably similar to mainline Protestantism anywhere else in the country. In fact, as Chapter 7 indicates, most changes actually took place in the North during the Gilded Age and Progressive Era. Methodists, Baptists, and Presbyterians in West Virginia remained faithful to traditional doctrines and practices but by no means isolated themselves.

The bonds between mainline denominations within and outside the mountains, coupled with the numerical superiority of mainline Protestants in the mountains, helped facilitate the incorporation of West Virginia into modern industrial American society. As Chapters 4 to 6 suggest, Methodists, Baptists, and Presbyterians remained deeply wedded to their religious traditions while at the same time desiring many of the same outcomes as the industrialists. Those factors limited their ability to challenge or resist capitalist take-over of the region. Some of the very characteristics of Protestant Christianity that could insulate it and protect it from secular incursions actually hindered its ability to critique the new order.

Four of those characteristics received particular attention here - democratic church polity, egalitarian theology, denominational unity, and emphasis on personal conversion and holiness. Each of those also falls under the aegis of popular religion. All of those traits are present to some extent in the three main Protestant denominations, and all three church bodies stayed involved with national denominational life. This national outlook in the sacred sphere mirrored a national outlook in the secular sphere. They earnestly desired to commune with their brothers and sisters 
across the country. They welcomed missionary help, but they fiercely guarded their autonomy and sought to preserve those elements of their faith they considered foundational. Most of the time they believed they were up to the task of spreading the gospel throughout the mountains without outside assistance.

The members of all three denominations remained committed to conservative theological positions, even as at the national level noticeable segments of their denominations re-interpreted traditional doctrines and ideas. Presbyterians displayed some egalitarianism in their insistence on personal conversion and their understanding that God directly intervenes in the lives of individuals to save them. In addition to the necessity of personal conversion, Methodists and Baptists exhibited the other aspects of popular religion more. At the local level, Baptists selected their own pastors. While the bishop appointed pastors for local Methodist circuits, those same circuits and constituent local congregations could choose local preachers and exhorters from among their members. Those men preached and taught under the auspices of the appointed pastor. Methodists and Baptists required no formal training or education for their clergy, and people from any social class could serve in the various churches offices. Presbyterians did require formal education, but anyone could serve as trustee, deacon, or elder. In the mountains, however, the upper class, whether agricultural or industrial, tended to control local Presbyterian congregations. $^{214}$

\footnotetext{
${ }^{214}$ To recapitulate, popular religiosity must be not be seen primarily as a response to deprivation in the physical world, although, as shown here, certain aspects of that were sometimes involved. The fact that many in Appalachia during industrialization suffered from various forms of deprivation, in particular declining economic and political power, does not mean they necessarily turned to ecstatic forms of religious experience. In fact, the data here shows that was extremely rare. Rather, the various examples of popular religion demonstrate a genuine belief, irrespective of temporal circumstances, in a sphere of supernatural power accessible in some way by mortals. The fact that this study, like others, focuses on those with little temporal authority does not indicate a deprivation theory. It serves to highlight the contrast between the sacred and secular spheres and call attention to key points of interaction between the two. See Deborah Vansau McCauley, Appalachian Mountain Religion: A History (Chicago: University of Illinois Press, 1995); Charles Lippy, "Popular Religion in Central Appalachia," in Christianity in Appalachia: Profiles in Regional Pluralism (Knoxville: The University of Tennessee Press, 1999), 42-48.
} 
Thus, the popular religiosity constituted an integral part of each mainline church and mainline religion constituted an integral part of Appalachian religion. The fact that popular religion pre-dated industrialization and that mainline denominations remained doctrinally conservative paints quite a different picture of mountain religion. The independent holiness movement that Richard Callahan documents arose in the twentieth century in part as a response to industrialization. The popular religion they embodied did in fact serve as reaction to the modern world. $^{215}$ Those believers drew on different religious traditions in the mountains, but the resultant sub-regional church was a product of the contact between Appalachia and outside forces, not a religious movement with a long organic history in that part of the country.

Deborah V. McCauley argues that Baptists and Methodists had become fully "denominationalized" by the late nineteenth century. This meant they pulled away from the revival heritage and became more institutionalized. More specifically, in terms of both doctrine and practice, the divide between churches in the highest elevations and those in the lower elevations and county seats increased. By the turn of the century, the mainline churches were completely outside the "mountain religious culture."216 But the mainline churches studied here had always been "denominationalized." Part of their very identity was being part of a greater communion. They retained that identity in the face of revolutionary forces both sacred and secular. Mainline West Virginia Protestants may have had similar religious convictions as the industrialists coming into the region, but that does not make existing churches examples of "railroad religion."

\footnotetext{
${ }^{215}$ Richard J. Callahan, Jr., Work and Faith in the Kentucky Coal Fields: Subject to Dust (Bloomington: Indiana University Press 1982), 133. See also Peter W. Williams, Popular Religion in America: Symbolic Change and the Modernization Process in Historical Perspective (Englewood Cliffs, NJ: Prentice-Hall, 1980), 11-17.

${ }^{216}$ Deborah V. McCauley, Appalachian Mountain Religion: A History (Chicago: University of Illinois Press, 1995), 265-267.
} 
Methodists, Baptists, and Presbyterians did not alter their beliefs or practices to become more accommodating to secular forces. The orthodoxy and orthopraxy may have gelled nicely with modernization, but popular religion in the Alleghenies was not the product of industrialization or the changes it brought. ${ }^{217}$ While the sacred sphere always exists in some relationship with the secular, popular religion in the mountains in many ways transcended the encroaching secular order. It did not challenge secular efforts to improve America's "Christian civilization," in large part because the sacred sphere shared that outlook.

The power of secular authority increased in the mountains. Henry Gassaway Davis, Stephen B. Elkins, and others like them established powerful railroad, coal, and timber empires. They exerted significant influence on state affairs. As Chapter 2 reveals, even those men could not withstand the tide they had unleashed on the mountains. The agents of industrialization saw their autonomy and power decrease around the turn of the twentieth century. While many people and businesses were at the mercy of Davis and Elkins, they themselves were at the mercy of even larger enterprises such as the Fuller Syndicate, the Baltimore and Ohio Railroad, and the Pennsylvania system, which were feuding among themselves and occasionally drifting in and out of receivership. Both the first and second Davis Rail Empires fell into rival hands by the end of the Progressive Era. The order associated with American industrialization was at times anything but orderly. ${ }^{218}$

Sacred authority decreased and secular authority increased as industrialization drew West Virginia firmly into the national market. Religion still played an important role in the Alleghe-

\footnotetext{
${ }^{217}$ Charles H. Lippy, Being Religious, American Style: A History of Popular Religiosity in the United States (Westport, CT: Praeger, 1994), 10-15.

${ }^{218}$ George H. Drury, The Historical Guide to North American Railroads: 160 Lines Abandoned or Merged Since 1930 (Waukesha, WI: Kalmbach Publishing, 1999), 35-40; Richard White, Railroaded: The Transcontinentals and the Making of Modern America (New York: W.W. Norton and Co., 2011), xxviii-xxxi.
} 
nies, but it increasingly labored for the secular, even as the faithful labored to redeem lost souls. However, religious agents and institutions in the mountains retained their identity and their ability to speak to people on a deeply personal, popular level. Local churches and state religious institutions clung to their autonomy from national denominations and businesses. At the same time, paragons of the Gilded Age in the Mountain State such as Davis and Elkins, as well as their local agents, fell victim to the overwhelming economic clout they once wielded against others. They could move mountains, but they failed to completely control the new secular power. They too became laborers, no longer lords of the harvest. 
Bibliography

\section{Manuscript Collections}

Anti-Saloon League of West Virginia. West Virginia and Regional History Collection, West Virginia University, Morgantown, West Virginia.

Davis, Henry Gassaway. Journal. Davis Trust Bank, Elkins, West Virginia.

Davis, Henry Gassaway. Papers. West Virginia and Regional History Collection, West Virginia University, Morgantown, West Virginia.

Davis, Thomas B. Papers. West Virginia and Regional History Collection, West Virginia University, Morgantown, West Virginia.

Greenbrier Railway Company, Records, Minutes. Chesapeake and Ohio Historical Society, Clifton Forge, Virginia.

Kump, Herman Guy. Papers. West Virginia and Regional History Collection, West Virginia University, Morgantown, West Virginia.

Rauschenbusch, Walter. Papers. Rauschenbusch Family Manuscript Collection, American Baptist Historical Society, Mercer University, Atlanta, Georgia.

West Virginia Central and Pittsburg Railway Company. Western Maryland Railway Historical Society, Union Bridge, Maryland.

\section{Congregational Sources}

“A Brief History of First United Methodist Church.” Keyser, WV: Self-Published Congregational History, 2006.

“Chronological Register.” Elkins Methodist Episcopal Church. 1897-1920.

“Church Covenant.” Davis Baptist Church, 1895.

The Dorcas/Maysville Parish. Maysville, WV: Self-Published Church History, 1967.

“Gormania Charge.” Mt. Storm United Methodist Church. Mt. Storm, WV, n.d.

Hallie Kyle, editor. Our Church History: Woodford United Methodist Church. Elkins, WV: Self Published, 1987.

"Historical Record: Mt. Storm United Methodist Church.” Mt. Storm United Methodist Church. Mt. Storm, WV: n.d. 
"History of First Methodist Church.” Keyser, WV: Self-Published Congregational History, n.d.

“Janes United Methodist Church.” Keyser, WV: Self-Published Congregational History, 2006.

"Letter to the Union Association." First Baptist Church of Elkins, 1894.

“Members.” Piedmont First Methodist Episcopal Church, 1888-1923.

“Membership Roll.” Harmony Baptist Church, 1906-1924.

"Minutes." Davis Baptist Church.

“Minutes.” First Baptist Church of Elkins, 1890-1917.

"Minutes.” Harmony Baptist Church, 1906-1924.

“Minutes.” Mineral Baptist Church, 1886-1918.

“Minutes of Session.” Huntersville Presbyterian Church, 1877-1920.

“Minutes of Session.” Keyser Presbyterian Church, 1876-1921.

“Minutes of Session.” Books I-II. Beverly Presbyterian Church, 1871-1983.

"Minutes of the Quarterly Conference." Keyser Station, 1908.

“Minutes of the Quarterly Conference.” Mingo Circuit, MEC, South, 1884-1886.

“Record of Trustees.” Keyser, MEC, South, 1894, 1907.

"Report of the Quarterly Conference." Huntersville Circuit, MEC, South, 1898-1919.

"Report of the Quarterly Conference.” Marlinton Circuit, MEC, South, 1906-1915.

"Register of Communicants.” Davis Memorial Presbyterian Church.

"Register of Communicants." Piedmont Presbyterian Church.

"Register of Communicants.” Keyser MEC, South, 1882-1917.

“Register of Communicants.” Books II and III. Beverly Presbyterian Church, 1891-1921.

"Register of Deacons." Davis Memorial Presbyterian Church.

“Register of Members.” Marlinton Circuit, MEC, South, 1906. 
"Records of the Session." Piedmont Presbyterian Church.

“Register of Stewards.” Elkins Methodist Episcopal Church, 1912-1913.

"Roll of Deacons." Piedmont Presbyterian Church.

"Roll of Elders." Piedmont Presbyterian Church.

“A Short, Incomplete History of Valley Chapel Church.” Beverly, WV: Self-Published Congregational History, n.d.

Smith, Mariwyn M. comp. “Chronological Roll.” 1992.

. "Parsons Presbyterian Church Elders." 1992.

. "Records and Minutes of the Presbyterian Church." 1992.

Smith, Paul A. One Hundred Fifty Years of God's Bounteous Blessings: The History of Piedmont Presbyterian Church, 1856-2006. Piedmont, WV: Self Published Church History, 2006.

“Quarterly Conference Records.” St. George Circuit, MEC, 1880.

“Quarterly Conference Roll,” Marlinton Charge of the Methodist Episcopal Church, 1915-1922.

“Quarterly Meeting Minutes of the St. George Circuit, MEC.” 1875-1885.

Denominational Sources

Annual of the Northern Baptist Convention, 1908-1922.

Annual of the Southern Baptist Convention, 1877-1899.

Annual Report of the American Baptist Home Mission Society. New York: ABMHS, 1888-1904.

"Chronological Register of Members." First Baptist Church of Elkins.

Doctrines and Discipline of the Methodist Episcopal Church. New York: The Methodist Book Concern, 1912.

The Doctrines and Discipline of the Methodist Episcopal Church, South. Nashville: Publishing House M.E. Church, South, 1910.

Eighth Annual Report of the Women's Missionary Council (Nashville: Publishing House for the Methodist Episcopal Church, South, 1918.

Journal of the General Conference of the Methodist Episcopal Church, 1875-1925. 
Journal of the General Conference of the Methodist Episcopal Church, South, 1875-1925.

Minutes of the American Baptist Publication Society. New York: ABPS, 1909.

Minutes of the Baltimore Annual Conference of the Methodist Episcopal Church, 1875-1925.

Minutes of the Baltimore Annual Conference of the Methodist Episcopal Church, South, 18761925.

Minutes of the Baptist General Association of West Virginia, 1868-1925.

Minutes of the Eastern Association, 1890-1925.

Minutes of the General Assembly of the Presbyterian Church in the United States, 1875-1925.

Minutes of the General Assembly of the Presbyterian Church of the United States of America, 1875-1925.

Minutes of the Greenbrier Presbytery, 1880-1925.

Minutes of the Lexington Presbytery, 1880-1912.

Minutes of the Meeting of the Formation of the Shenandoah Baptist Association. New Market, VA: Henkel \& Co. Printers, 1882.

Minutes of the Presbytery of Tygart's Valley, 1912-1925.

Minutes of the Synod of Kentucky, 1882.

Minutes of the Synod of Virginia, 1880-1925.

Minutes of the Virginia Conference of the Methodist Episcopal Church, 1874-1906.

Minutes of the Union Baptist Association, 1826; 1880-1925.

Minutes of the West Virginia Conference, Methodist Protestant Church, 1877, 1907.

Minutes of Winchester Presbytery, 1880-1925.

Official Journal of the West Virginia Conference of the Methodist Episcopal Church, 1875-1925.

“Official Register of Clerks.” First Baptist Church of Elkins.

"Official Register of Deacons." First Baptist Church of Elkins.

"Official Register of Sunday School Superintendents." First Baptist Church of Elkins. 
“Official Register of Treasurers.” First Baptist Church of Elkins.

Sixty-Fifth Annual Report of the American Baptist Missionary Union. New York: ABMU, 1879.

Western Virginia Conference Journal, Methodist Episcopal Church, South, 1878-1925.

Other Archival Sources

Minutes of the Annual Meeting of the Woman's Christian Temperance Union of West Virginia, 1900-1917.

Government Documents

Religious Bodies, 1926, Volume 2, Separate Denominations. Statistics, history, doctrine, organization, and work. Washington, DC: Government Printing Office, 1929.

$9^{\text {th }}$ Census of the United States, Taken in 1870, Volume 1, Population, General Report and Analysis. Washington, DC: Government Printing Office, 1873.

$10^{\text {th }}$ Census of the United States, Taken in 1880, Volume 1, Population, General Report and Analysis. Washington, DC: Government Printing Office, 1883.

$12^{\text {th }}$ Census of the United States, Taken in 1900, Volume 1, Population, General Report and Analysis. Washington, DC: Government Printing Office, 1903.

$13^{\text {th }}$ Census of the United States, Taken in 1910, Volume I, Population, General Report and Analysis. Washington, DC: Government Printing Office, 1913.

14th Census of the United States, Taken in 1920, Volume I, Population, General Report and Analysis. Washington, DC: Government Printing Office, 1923.

Newspapers

Baltimore American

The Baptist Banner

The Baptist Home Mission Monthly

Central Presbyterian

Daily Inter-Mountain

Elk Garden News

Elkins Inter-Mountain 
The Freeman

Grant County Press

Keyser Daily News

Mineral Daily News

New York Tribune

Parsons Advocate

Pocahontas Times

Randolph Enterprise

Religious Telescope

Tucker Democrat

Tygart Valley Press

Wheeling Intelligencer

\section{Secondary Sources}

Abell, Troy D. Better Felt than Said: The Holiness-Pentecostal Experience in Southern Appalachia. Waco: Markham, 1982.

Abraham, William J. and James E. Kirby, eds. The Oxford Handbook of Methodist Studies. New York: Oxford University Press, 2009.

Ahlstrom, Sydney E. A Religious History of the American People, vol. 2. New York: Image Books, 1975.

Allen. T.P. The West Virginia Hills: A Study of the Works of the Presbyterian Church in the United States in the Synod of West Virginia. St Louis: Buxton \& Skinnery, 1927.

Alley, Reuben E. A History of Baptists in Virginia. Richmond: Virginia Baptist Publishing Board, 1969.

Ambler, Charles H. Francis H. Pierpont, Union War Governor of Virginia and Father of West Virginia. Chapel Hill: The University of North Carolina Press, 1937.

. The Makers of West Virginia and Their Work. Huntington, WV: Gentry Brothers, 1942. 
. Sectionalism in Virginia. Chicago: University of Chicago Press, 1910.

Anderson, Robert Mapes. Vision of the Disinherited: The Making of American Pentecostalism. New York: Oxford, 1979.

Andrews, Dee E. The Methodists and Revolutionary America, 1760-1800: The Shaping of An Evangelical Culture. Princeton: Princeton University Press, 2000.

Baker, George Pratt. Those Incredible Methodists: A History of the Baltimore Conference of the United Methodist Church. Baltimore: Commission on Archives and Records, Baltimore Conference, 1972.

Balmer, Randall. The Making of Evangelicalism: From Revivalism to Politics and Beyond. Waco: Baylor University Press, 2010.

Balmer, Randall and John R. Fitzmier. The Presbyterians. London: Praeger, 1994.

Barclay, William Crawford. The Methodist Episcopal Church, 1845-1939, Vol. 3: 1845-1895. New York: The Board of Missions of the Methodist Church, 1957.

Bensel, Richard Franklin. Political Economy of American Industrialization, 1877-1900. Cambridge: Cambridge University Press, 2000.

. Yankee Leviathan: The Origins of Central State Authority: 1859-1877. New York: Cambridge University Press, 1999.

Billings, Dwight B and Kathleen M. Bless. The Road to Poverty: The Making of Wealth and Hardship in Appalachia. Cambridge: Cambridge University Press, 2000.

Bittenger, Emmert F. Allegheny Passages: Churches and Families, West Marva District, Church of the Brethren, 1752-1900. Camden, ME: Penobscot Press, 1990.

Bodkins, Steve. Bemis and Glady West Virginia: A History of Two Mountain Towns. Parsons, WV: McClain Printing Company, 2006.

Bordin, Ruth. Women and Temperance: The Quest for Power and Liberty, 1873-1900. New Brunswick: Rutgers University Press, 1990.

Brackney, William H. The Baptist. Westport, CT: Praeger, 1994. . A Genetic History of Baptist Thought. Macon: Mercer University Press, 2004.

Brands, H.W. American Colossus: The Triumph of Capitalism, 1865-1900. New York: Random House, 2010. 
Brumbaugh, Martin Grove. A History of the German Baptist Brethren in Europe and America. Reprint. Ithaca, NY: Cornell University Library, 2009.

Brown, Richard D. Modernization: The Transformation of American Life, 1600-1865. New York: Hill and Wang, 1976.

Brown, William Adams. "Changes in the Theology of American Presbyterianism." The American Journal of Theology 10 (July 1906) : 387-411.

Bruce, Dickson D. And They All Sang Hallelujah: Plain-folk Camp-meeting Religion, 18001845. Knoxville: The University of Tennessee Press, 1981.

Burgess, Stanley M. and Eduard M van der Maas, eds. The New International Dictionary of Pentecostal and Charismatic Movements. Grand Rapids: Zondervan, 2002.

Burrows, Carl E., Robert B. Florian, David F. Mahoney. Melting Times: A History of West Virginia United Methodism. Charleston, WV: Commission on Archives and History, West Virginia Conference, United Methodist Church, 1984.

Calhoun, Charles W. "Civil Religion and the Gilded Age Presidency: The Case of Benjamin Harrison.” Presidential Studies Quarterly 23 (Fall 1993) : 651-667.

Calhoun, Charles W., ed. The Gilded Age: Perspectives on the Origins of Modern America. New York: Rowman \& Littlefield Publishers, Inc., 2007.

Callahan, Jr., Richard J. Work and Faith in the Kentucky Coal Fields: Subject to Dust. Bloomington: Indiana University Press, 1982.

Cannon III, James. History of Southern Methodist Missions. Nashville: Cokesbury Press, 1926.

Carpenter, Joel A. Revive Us Again: The Reawakening of American Fundamentalism. New York: Oxford University Press, 1997.

Clarke, Alan R. The West Virginia Central and Pittsburgh Railway: A Western Maryland Predecessor. Lynchburg, VA: TLC Publishing, 2003.

. West Virginia's Coal and Coke Railway: A B\&O Predecessor. Lynchburg, VA: TLC Publishing, Inc., 2002.

. The West Virginia and Pittsburgh Railroad: The B\&O's Road to the Hardwoods. Charleston, WV: Quarrier Press, 2008.

Clarkson, Roy B. On Beyond Leatherbark: The Cass Saga. Parsons, WV: McClain Printing Company, 1990. 
Coalter, Milton J., John M. Mulder, and Louis B. Weeks, eds. The Diversity of Discipleship: The Presbyterians and Twentieth-Century Christian Witness. Louisville: Westminster/John Knox Press, 1991.

. The Reforming Tradition: Presbyterians and Mainstream Protestantism. Louisville: Westminster/John Knox Press, 1992.

. Tumult on the Mountains: Lumbering in West Virginia, 1770-1920. Parsons, WV: McClain Printing Company, 1964.

Coker, Joe L. Liquor and the Lost Cause: Southern White Evangelicals and the Prohibition Movement. Lexington: The University of Kentucky Press, 2007.

Collins, Kenneth J. The Evangelical Moment: The Promise of An American Religion. Grand Rapids: Baker, 2005.

. Power, Politics, and the Fragmentation of Evangelicalism: From the Scopes Trial to the Obama Administration. Downers Grove, IL: IVP Academic, 2012.

Corbin, David. Life, Work, and Rebellion in the Coal Fields. Chicago: University of Illinois Press, 1981.

Crunden, Robert M. Ministers of Reform: The Progressives'Achievement in American Civilization, 1889-1920. New York: Basic Books, 1982.

Curry, Richard O. "A Reappraisal of Statehood Politics in West Virginia." The Journal of Southern History 28, No. 4 (Nov., 1962) : 403-421.

. A Study of Statehood Politics and the Cooperhead Movement in West Virginia. Pittsburgh: University of Pittsburgh Press, 1964.

Davis, David Brion, editor. Ante-Bellum Reform. New York: Harper and Row, 1967.

Dayton, Donald. Discovering an Evangelical Heritage. Grand Rapids: Baker Academic, 1988. . "The Embourgeoisement of a Vision: Lament of a Radical Evangelical." The Other Side: Strength for the Journey 23, No. 8 (1987) : 19.

DeWeese, Charles W. Women Deacons and Deaconessess: 400 Years of Baptist Service. Mercer: Macon University Press, 2005.

De Santis, Vincent P. The Shaping of Modern America, 1877-1920. Wheeling, IL: Harlan Davidson, Inc., 2000.

Dixon, Jr. Thomas W. Chesapeake and Ohio Allegheny Subdivision. Alderson, WV: Chesapeake and Ohio Historical Society, 1985. 
. "The Chesapeake and Ohio Railway in Greenbrier." Journal of the Greenbrier Historical Society 3 (Winter, 1978) : 21-63.

Doctrines and Discipline of the Methodist Episcopal Church. New York: The Methodist Book Concern, 1912.

The Doctrines and Discipline of the Methodist Episcopal Church, South. Nashville: Publishing House M.E. Church, South, 1910.

Dorgan, Howard. Giving Glory to God in Appalachia: Worship Practices of Six Baptist Subdenominations. Knoxville: University of Tennessee Press, 1987.

Dorn, Jacob Henry. Washington Gladden: Prophet of the Social Gospel. Columbus: Ohio State University Press, 1967.

Dorrien, Gary. The Making of American Liberal Theology: Imagining Progressive Religion, 1805-1900. Louisville: Westminster/John Knox Press, 2001.

. The Making of American Liberal Theology: Idealism, Realism, and Modernity, 19001950. Louisville: Westminster/John Knox Press, 2003.

. The Remaking of Evangelical Theology. Louisville: Westminster/John Knox Press, 1998.

Dotson, Rand. Roanoke Virginia, 1882-1912: Magic City of the New South. Knoxville: The University of Tennessee Press, 2007.

Drury, George H. The Historical Guide to North America Railroads, 160 Lines Abandoned or Merged Since 1930. Waukesha, WI: Kalmbach Publishing, 1999.

Dunaway, Wilma A. The First American Frontier: Transition to Capitalism in Southern Appalachia, 1700-1860. Chapel Hill: The University of North Carolina Press, 1996.

Edwards, Rebecca. New Spirits, 1856-1905. New York: Oxford University Press, 2006.

Edwards, Wendy J. Deichmann and Carolyn Swarte Gifford, eds. Gender and the Social Gospel. Chicago: University of Illinois Press, 2003.

Eller, Ronald. Miners, Millhands, and Mountaineers: Industrialization of the Appalachian South, 1880-1930. Knoxville: The University of Tennessee Press, 1982.

Elwell, Walter A., ed. Evangelical Dictionary of Theology, 2nd Edition. Grand Rapids: Baker Academic, 2001.

Evans, Christopher H. The Kingdom is Always but Coming: A Life of Walter Rauschenbusch. Grand Rapids: Eerdmans, 2004. 
Evans, Christopher H. Liberalism Without Illusions: Renewing an American Christian Tradition. Waco: Baylor University Press, 2010.

Fain, Cicero. "Into the Crucible: The Chesapeake and Ohio Railroad and the Black Industrial Worker in Southern West Virginia, 1870-1900. Journal of Appalachian Studies 17 (Spring and Fall 2011) : 42-65.

Fansler, Homer Floyd. History of Tucker County, West Virginia. Parsons, WV: McClain Printing Company, 1962.

Farmer, Jr., James Oscar. The Metaphysical Confederacy: James Henry Thornwell and the Synthesis of Southern Values. Macon: Mercer University Press, 1986.

Fetters, Paul R. Trials and Triumphs: A History of the Church of the United Brethren in Christ. Huntington, IN: Dept. of Church Services, 1984.

Finke, Roger and Rodney Stark. The Churching of America, 1776-2005: Winners and Losers in Our Religious Economy. New Brunswick: Rutgers, 2005.

Fletcher, Holly Berkley. Gender and the American Temperance Movement of the Nineteenth Century. New York: Routledge, 2008.

Flint, Wayne. "Dissent in Zion: Alabama Baptists and Social Issues, 1900-1914.” Journal of Southern History 35 (Winter 1969) : 532-542.

. "One in the Spirit, Many in the Flesh: Southern Evangelicals." In Varieties of Southern Evangelicalism. Edited by David Edwin Harrell, Jr., 23-44. Macon: Mercer University Press, 1981.

Flint, Wayne. "Southern Baptists and Reform, 1890-1920." Baptist History and Heritage 7 (October 1972) : 211-222.

Fones-Wolf, Ken. Glass Towns: Industry, Labor, and Political Economy in Appalachia, 18901930s. Urbana: University of Illinois Press, 2007.

. Trade Union Gospel: Christianity and Labor in Industrial Philadelphia, 1865-1915. Philadelphia: Temple University Press, 1989.

Fortson III, S. Donald. "New School Calvinism and the Presbyterian Creed." The Journal of Presbyterian History 82 (Winter 2004) : 221-243.

Foulds, Matthew. "Enemies of the State: Methodists, Secession, and the Civil War in Western Virginia, 1845-1872." PhD diss., The Ohio State University, 2012. ProQuest (3521017). 
Fox-Genovese, Elizabeth and Eugene D. Genovese. The Mind of the Master Class: History and Faith in the Southern Slaveholders' Worldview. New York: Cambridge University Press, 2005.

Genovese, Eugene D. Consuming Fire: The Fall of the Confederacy in the Mind of the White Christian South. Athens: University of Georgia Press.

. The Slavehoders'Dilemma: Freedom and Progress in Southern Conservative Thought, 1820-1860. Columbia: University of South Carolina Press, 1992.

Grammich, Jr., Clifford A. Local Baptists, Local Politics: Churches and Communities in the Middle and Uplands South. Knoxville: The University of Tennessee Press, 1999.

Grantham, Dewey W. "The Contours of Southern Progressivism.” The American Historical Review 86 (Dec., 1981) : 1035-1059.

Goen, C.C. Broken Churches, Broken Nation: Denominational Schisms and the Coming of the Civil War. Macon: Mercer University Press, 1985.

Green, James R. "The Brotherhood of Timber Workers 1910-1913: A Radical Response to Industrial Capitalism in the Southern U.S.A.” Past and Present, 60 (Aug., 1973) : 161-200.

Grenz, Stanley J. and Roger E. Olsen. 20 ${ }^{\text {th }}$ Century Theology: God and the World in Transition. Downers Grove, IL: Intervarsity Press, 1992.

Grew, Raymond. "More on Modernization.” Journal of Social History 14 (Winter 1980) : 179188.

Griffin, Sam. West Virginia Central and Pittsburg Railway Company. Indianapolis: The Independent Job Room, 1899.

Gude, Gilbert. Where the Potomac Begins: A History of the North Branch Valley. Cabin John, MD: Seven Locks Press, 1984.

Hall, Granville D. The Rending of Virginia: A History. Reprint. Knoxville: The University of Tennessee Press, 2000.

Hamm, Richard F. Shaping the $18^{\text {th }}$ Amendment: Temperance Reform, Legal Reform, and the Polity, 1880-1920. Chapel Hill: The University of North Carolina Press, 1995.

Handy, Robert T. A Christian America: Protestant Hopes and Historical Realities. New York: Oxford University Press, 1984.

Hank, Arthur, A.B. Withers, and John S. Stump, eds. Baptist General Association of West Virginia: Jubilee Volume. s.1.: s.n., 1915. 
Hankins, Barry. Uneasy in Babylon: Southern Baptist Conservatives and American Culture. Tuscaloosa: The University of Alabama Press, 2002.

Harper, Keith. The Quality of Mercy: Southern Baptists and Social Christianity, 1890-1920. Tuscaloosa: The University of Alabama Press, 1996.

Harper, Keith, ed. American Denominational History: Perspectives on the Past, Prospects for the Future. Tuscaloosa: The University of Alabama Press, 2008.

Harkness, Georgia. The Methodist Church in Social Thought and Action. Nashville: Abingdon Press, 1964.

Hatch, Nathan O. The Democratization of American Christianity. New Haven: Yale, 1989.

Heitzenrater, Richard P. Wesley and the People Called Methodists. Nashville: Abingdon Press, 1995.

Hempton, David. Methodism and the Empire of the Spirit. New Haven: Yale University Press, 2005.

Hennen, John C. The Americanization of West Virginia: Creating a Modern Industrial State, 1916-1925. Lexington: University of Kentucky Press, 1996.

. "Benign Betrayal: Capitalist Intervention in Pocahontas County, West Virginia, 18901910.” West Virginia History 50, (1991) : 46-62.

Hill, Craig C. In God's Time: The Bible and the Future. Grand Rapids: Eerdmans, 2002.

Hill, Samuel S. One Name but Several Faces: Variety in Popular Christian Denominations in Southern History. Athens, GA: The University of George Press, 1996.

Hill, Samuel S., editor. Religion in the Southern States: A Historical Study. Macon: Mercer University Press, 1983.

Hobsbawm, Eric. The Age of Capital: 1848-1875. New York: Vintage Book, 1975.

Holmes, Darrell E., editor. West Virginia Blue Book. Charleston, WV: Chapman Printing, 2001.

Hooker, Elizabeth. Religion in the Highlands: Native Churches and Missionary Enterprise in the Southern Mountain Area. New York: Home Mission Council, 1933.

Hopkins, Charles Howard. The Rise of the Social Gospel in American Protestantism, 1865-1915. New Haven: Yale University Press, 1940.

Hudson, Winthrop S., editor. Walter Rauschenbusch: Selected Writings. Mahwah, NJ: Paulist Press, 1984. 
Huibregtse, Jon. R. American Railroad Labor and the Genesis of the New Deal, 1919-1935. Gainesville, FL: University of Florida Press, 2010.

Humphreys, Fisher and Philip Wise. Fundamentalism. Macon: Smith \& Helwys, 2004.

Hutchinson, John A. We Are Not Divided: A Critical and Historical Study of The Federal Council of the Churches of Christ in America. New York: Round Table Press, 1941.

Jacobson, Matthew Fyre. Barbarian Virtues: The United States Encounters Foreign Peoples At Home and Abroad, 1876-1917. New York: Hill and Wang, 2000.

Jones, Charles Edwin. Perfectionist Persuasion: The Holiness Movement and American Methodism, 1867-1936. Metuchen, NJ: The Scarecrow Press, Inc., 1974.

Jones, Loyal. Faith and Meaning in the Southern Uplands. Chicago: The University of Illinois Press, 1999.

Judy, E.L. History of Grant and Hardy Counties, West Virginia. Charleston, WV: Charleston Printing Company, 1951.

Kraut, Alan M. The Huddled Masses: The Immigrant in American Society, 1880-1921. Wheeling, IL: Harlan Davidson, Inc., 2001.

Lears, T.J. Jackson, No Place of Grace: Antimodernism and the Transformation of American Culture, 1880-1920. Chicago: University of Chicago Press, 1981. . Rebirth of a Nation. New York: Harper, 1999.

Leonard, Bill. Baptist Ways: A History. Valley Forge, PA: Judson Press, 2003.

. "Conviction and Contradiction: Reassessing Theological Formation in Baptist Identity." Baptist History and Heritage 47 (Summer 2012) : 6-25.

Leonard, Bill J., editor. Christianity in Appalachia: Profiles of Regional Pluralism. Knoxville: The University of Tennessee Press, 1999.

Lewis, Ronald L. Transforming the Appalachian Countryside: Railroads, Deforestation, and Social Change in West Virginia, 1880-1920. Chapel Hill: The University of North Carolina Press.

Lewis, Ronald L. and John C. Hennen, editors. West Virginia: Documents in the History of a Rural-Industrial State. Dubuque, IA: Kendall/Hunt Publishing, 1996.

Lewis, Sean Michael. Robert Lewis Dabney: A Southern Presbyterian Life. Philipsburg, NJ: P\&R Publishing Company, 2005. 
Link, William A. The Paradox of Southern Progressivism, 1880-1930. Chapel Hill: The University of North Carolina Press, 1992.

Lippy, Charles H. Being Religious, American Style: A History of Popular Religiosity in the United States. Westport, CT: Praeger, 1994.

Livingston, James C. Modern Christian Thought: The Enlightenment and the Nineteenth Century. Minneapolis: Fortress Press, 2006.

Loetscher, Lefferts A. A Brief History of the Presbyterians. Philadelphia: Westminster Press, 1978.

Long, Cleta M. History of Tucker County, West Virginia. Parsons, WV: McClain Printing Company, 1997.

Longfield, Bradley J. The Presbyterian Controversy: Fundamentalists, Modernists, and Moderates. New York: Oxford, 1991.

Lumpkin, William J. and Bill J. Leonard, editors. Baptist Confessions of Faith, 2nd Revised Edition. Valley Forge, PA: Judson Press, 2011.

Lucas, Sean Michael. " 'Our Church Will Be On Trial"” W.M. McPheeters and the Beginnings of Conservative Dissent in the Presbyterian Church in the United States." The Journal of Presbyterian History 84, No. 1 (Spring/Summer 2006) : 52-66.

Lunt, Richard D. Law and Order vs. The Miners: West Virginia, 1907-1933. Hamden, CT: Archon Books, 1979.

Marsden, George. Fundamentalism and American Culture. Oxford: Oxford University Press, 2006.

. Reforming Fundamentalism: Fuller Seminary and the New Evangelicalism. Grand Rapids: Eerdmans, 1987.

Martin, Daisy Ferguson. Montrose Community History. Elkins, WV: Published for the Montrose Historical Society, 1991.

Mathis, James R. The Making of the Primitive Baptists: A Cultural and Intellectual History of the Antimission Movement, 1800-1840. New York: Routledge, 2004.

Maxwell, Hu. The History of Randolph County, West Virginia. Morgantown, WV: The Acme Publishing Company, 1896.

. History of Tucker County, West Virginia. Kingwood, WV: Preston Publishing Company, 1884. 
McBeth, Leon H. The Baptist Heritage: Four Centuries of Baptist Witness. Nashville: Broadman Press, 1987.

McCaleb, Walter F. Brotherhood of Railroad Trainmen. New York: Albert \& Charles Boni, 1936.

McCauley, Deborah V. Appalachian Mountain Religion. Chicago: The University of Illinois Press, 1995.

. "Religion." In High Mountains Rising: Appalachia in Time and Place, edited by Richard A Straw and H. Tyler Blethen, 179-196. Chicago: The University of Illinois Press, 204.

McCrossen, Alexis. Holy Day, Holiday: The American Sunday. Ithaca, NY: Cornell University Press, 2000.

McDowell, John Patrick. The Social Gospel in the South: The Women's Home Mission Movement in the Methodist Episcopal Church, South, 1886-1939. Baton Rouge: Louisiana State University Press, 1982.

McKinney, William Wilson. The Presbyterian Valley. Pittsburgh: Davis \& Ward, Inc., 1958.

McLoughlin, William G. Revivals, Awakenings, and Reform. Chicago: University of Chicago Press, 1980.

McNeel, William Price. The Durbin Route: The Greenbrier Division of the Chesapeake and Ohio Railway. Charleston, WV: Pictorial Historical Publishing Company, 1985.

McNeel, William Price and Jane Price Sharp, editors. History of Pocahontas County, West Virginia, 1981: Birthplace of Rivers. Marlinton, WV: Pocahontas County Historical Society, 1981.

Middleton, P. Harvey. Railways and Organized Labor. Chicago: Railway Business Association, 1941.

Moberg, David O. The Great Reversal: Evangelism Versus Social Concern. Philadelphia: Lippincott, 1972.

Moore, George Ellis. A Banner in the Hills: West Virginia's Statehood. New York: AppletonCentury-Crofts, 1963.

Mott, Pearle G. History of Davis and Canaan Valley. Parsons, WV: McClain Publishing Company, 1972. . History of Methodism in Davis, West Virginia: 1885-1964. S.1.: s.n., 1965. 
Noe, Kenneth W. Southwest Virginia's Railroad: Modernization and the Sectional Crisis. Urbana-Champaign: University of Illinois Press, 1994.

Noll, Mark A. The Scandal of the Evangelical Mind. Grand Rapids: Eerdmans, 1994.

Noll, Mark, ed. God and Mammon: Protestants, Money, and the Market, 1790-1860. New York: Oxford University Press, 2002.

Norwood, Frederick A. The Story of American Methodism. Nashville: Abingdon Press, 1974.

Pepper, Charles M. The Life and Times of Henry Gassaway Davis, 1823-1916. New York: The Century Co., 1920.

Photiadis, John D. Religion in Appalachia: Theological, Social, and Psychological Dimensions and Correlates. Morgantown, WV: Center for Extension and Continuing Education, 1978.

Pudup, Mary Beth, Dwight Billings, and Altina L. Waller, eds. Appalachia in the Making: The Mountain South in the Nineteenth Century. Chapel Hill: The University of North Carolina Press, 1998.

O'Brien, Betty. "The Lord's Supper: Fruit of the Vine or Cup of Devils?" Methodist History 31, No. 4 (1993) : 203-223.

Overmeyer, Joe B. History of the Presbytery of Kanawha, 1895-1965. Charleston, WV: Jarrett Printing Company, 1957.

Ownby, Ted. Subduing Satan: Religion, Recreation, and Manhood in the Rural South, 18651920. Chapel Hill: The University of North Carolina Press, 1900.

Rasmussen, Barbara. Absentee Landowning and Exploitation in West Virginia, 1760-1920. Lexington: The University of Kentucky Press, 1994.

Rauschenbusch, Walter. Christianizing the Social Order. New York: MacMillan, 1912. . A Theology for the Social Gospel. New York: Abingdon, 1917.

Rice, Donald L. Bicentennial History of Randolph County, West Virginia, 1787-1987. Elkins, WV: Randolph County Historical Society, 1987.

Rice, Donald L, ed. The Elkins Centennial Album, 1890-1990. Parsons, WV: McClain Printing Company, 1990.

, ed. Randolph 200: A Bicentennial History of Randolph County, West Virginia. Marceline, MO: Walsworth Press, 1987. 
Rice, William H. Elkins, West Virginia, 1889: The Magic City of the Wilderness. Parsons, WV: McClain Printing Company, 2007.

Richey, Russell E., Kenneth E. Rowe, and Jean Miller Schmidt. The Methodist Experience in America: A History, Vol. 1. Nashville: Abingdon Press, 2010.

. The Methodist Experience in America: A Sourcebook, Vol. 2. Nashville: Abingdon Press, 2000.

Riesebrodt, Martin. Pious Passions: The Emergence of Modern Fundamentalism in the United States and Iran. Translated by Don Reneau. Los Angeles: University of California Press, 1993.

Robbins, Edwin Clyde. Railway Conductors: A Study in Organized Labor. New York: Columbia University Press, 1914.

Rogers, Truett. West Virginia Baptist History: The Convention Years, 1865-1965. Terra Alta, WV: Headline Books, 1994.

West Virginia Baptist History: The Early Years, 1770-1865. Terra Alta, WV: Headline Books, 1990.

Ross, Thomas Richard. The Davis Memorial Presbyterian Church 1895-1995: A Century of Service. Parsons, WV: McClain Printing Company, 1995.

. Henry Gassaway Davis: An Old Fashioned Biography. Parsons, WV: McClain Printing Company, 1994.

Rossinow, Doug. "The Radicalization of the Social Gospel: Harry F. Ward and the Search for a New Social Order, 1898-1936. Religion and American Culture: A Journal of Interpretation 15, No. 1 (Winter 2005) : 63-106.

Ryrie, Charles. Dispensationalism. Chicago: Moody Press, 2007.

Sandeen, Ernest R. The Roots of Fundamentalism: British and American Millenarianism, 18001930. Chicago: The University of Chicago Press, 1970.

Sanders, Marthame E. “ 'A Fellowship of Concern' and the Declining Doctrine of the Spirituality of the Church in the United States." The Presbyterian Journal of History 75 (Fall, 1997) : 179-195.

Schaff, Philip, ed. The Creeds of Christendom: The Creeds of the Evangelical Protestant Churches, Vol. 3. Grand Rapids: Baker Books, 2007.

Schlereth, Thomas J. Victorian America: Transformations in Everyday Life, 1876-1915. New York: HarperPerenial, 1991. 
Schmidt, Jean Miller. Grace Sufficient: A History of Women in American Methodism, 1760-1939. Nashville: Abingdon Press, 1999.

Schmidt, Leigh Eric. Holy Fairs: Scotland and the Making of American Revivalism. Princeton: Princeton University Press, 1989.

Schneider, Robert A. "The Federal Council of Churches and American Presbyterians, 19001950.” The Journal of Presbyterian History 84, No. 2 (Fall/Winter 2006) : 103-122.

Schweiger, Beth Barton. The Gospel Working Up: Progress and the Pulpit in Nineteenth-Century Virginia. New York: Oxford University Press, 2000.

Semple, Robert Baylor. A History of the Rise and Progress of the Baptists in Virginia. Richmond: Pitt and Dickinson, 1894.

Shapiro, Henry D. Appalachia on Our Mind: The Southern Mountains and Mountaineers in the American Consciousness, 1870-1920. Chapel Hill: The University of North Carolina Press, 1978.

Shurden, Walter B., ed. Proclaiming the Baptist Vision: Baptism and the Lord's Supper. Macon, GA: Smith \& Helwys Publishing, Inc., 1999.

. Proclaiming the Baptist Vision: The Church. Macon: Smith \& Helwys Publishing, Inc., 1996.

Proclaiming the Baptist Vision: The Priesthood of All Believers. Macon: Smith \& Helwys Publishing, Inc., 1993.

Shifflett, Crandall A. Coal Towns. Knoxville: The University of Tennessee Press, 1991.

Siedman, Joel. The Brotherhood of Railroad Trainmen: The Internal Political Life of a National Union. New York: John Wiley and Sons, Inc., 1962.

Silber, Nina. The Romance of Reunion: Northerners and the South, 1865-1900. Chapel Hill: The University of North Carolina Press, 1993.

Silver, James W. "The Hardwood Producers Come of Age," The Journal of Southern History 23 (Nov., 1957) : 427-453.

Singer, Gregg C. The Unholy Alliance. New Rochelle, NY: Arlington House Publishing, 1975.

Sledge, Robert W. Five Dollars and Myself: The History of Mission of the Methodist Episcopal Church, South, 1845-1939. New York: General Board of Global Ministries, 2005.

Smith, Morton H. Studies in Southern Presbyterian Theology. Philipsburg, NJ: Presbyterian and Reformed Publishing Company, 1962. 
Smucker, Donovan. The Origin of Rauschenbusch's Social Ethic. London: McGill-Queen's Press, 1994.

Smylie, James H. A Brief History of the Presbyterian Church. Louisville: Geneva Press, 1996.

Spain, Rufus B. At Ease in Zion: A Social History of Southern Baptists, 1865-1900. Tuscaloosa, AL: The University of Alabama, 2003.

Stearns, Peter N. "Modernization and Social History, Some Suggestions and a Muted Cheer." Journal of Social History 14 (Winter 1980) : 189-209.

Stewart, Bruce E. Moonshiners and Prohibitionists: The Battle over Alcohol in Southern Appalachia. Lexington: The University of Kentucky Press, 2011.

Storey, John W. Texas Baptist Leadership and Social Christianity, 1900-1980. College Station, TX: Texas A\&M Press, 1986.

Stowell, Daniel W. Rebuilding Zion: The Religious Reconstruction of the South, 1863-1877. New York: Oxford University Press, 1998.

Synan, Vinson. The Holiness-Pentecostal Tradition. Grand Rapids: Eerdmans, 1977.

Szymanski, Ann-Marie E. Pathways to Prohibition: Radicals, Moderates, and Social Movement Outcomes. Durham, NC: Duke University Press, 2003.

Taillon, Paul Michel. Good, Reliable, White Men: Railroad Brotherhoods, 1877-1917. Chicago: University of Illinois Press, 2009.

Teter, Don. Goin' Up Gandy: A History of the Dry Fork Region of Randolph and Tucker Counties West Virginia. Parsons, WV: McClain Printing Company.

Thompson, Ernest Thrice. Presbyterians in the South, 3 Volumes: 1607-1972. Richmond: John Knox Press.

Trachtenberg, Alan. The Incorporation of America: Culture and Society in the Gilded Age. New York: Hill and Wang, 1982.

Utzinger, J. Michael. Yet Saints Their Watch Are Keeping: Fundamentalists, Modernists, and the Development of an Evangelical Ecclesiology, 1887-1937. Macon, GA: Mercer University Press, 2004.

Wallerstein, Immanuel. World-Systems Analysis: An Introduction. Durham, NC: Duke University Press, 2004. 
Walters, Ronald G. The Antislavery Appeal: American Abolitionism after 1830. New York: W.W. Norton and Company, 1984.

Weber, Timothy P. Living in the Shadow of the Second Coming: American Premillennialism, 1875-1925. New York: Oxford University Press, 1979.

Westerfield, Karen B. American Methodist Worship. New York: Oxford University Press, 2001.

Whisnant, David. All That is Native and Fine. Chapel Hill: The University of North Carolina Press, 1983.

White, Richard. Railroaded: The Transcontinentals and the Making of Modern America. New York: W.W. Norton and Co., 2011.

White, Jr., Ronald C. and C. Howard Hopkins. The Social Gospel: Religion and Reform in Changing America. Philadelphia: Temple University Press, 1976.

Wiebe, Robert H. The Search for Order 1877-1920. New York: Hill and Wang, 1967.

Williams, John Alexander. Appalachia: A History. Chapel Hill: The University of North Carolina Press, 2002.

. "The New Dominion and the Old: Ante-Bellum and Statehood Politics As the Background of West Virginia's 'Bourbon Democracy'," West Virginia History 33 (Jan. 1972) : 317-407.

. West Virginia: A History. Morgantown, WV: West Virginia University Press, 2001.

. West Virginia and the Captains of Industry. Morgantown, WV: West Virginia University Press, 2003.

Williams, Sr., Michael E. Isaac Taylor Tichenor: The Creation of the Baptist New South. Tuscaloosa: The University of Alabama Press, 2005.

Williams, Peter W. Popular Religion in America: Symbolic Change and Modernization Process in Historical Prospective Englewood Cliffs, NJ: Prentice-Hall, Inc., 1980.

Wilson, Gill I. The Story of Presbyterianism in West Virginia. S.l. : s.n., 1958.

Wilson, Howard M. The Lexington Presbytery Heritage: The Presbytery of Lexington and its churches in the Synod of Virginia, Presbyterian Church in the United States. Verona, VA: McClure Printing Company, Inc., 1971.

Woodworth, Robert Bell. A History of the Presbytery of Winchester (Synod of Virginia): Its Rise and Growth, Ecclesiastical Relations, Institutions and Agencies, Churches and Ministers, 1719-1915. Staunton, VA: The McClure Printing Company, 1947. 
Workman, Michael E., Paul Salstrom, Philip Ross. Northern West Virginia Coal Fields: Historical Context. Morgantown, WV: Institute for the History of Technology and Industrial Archeology, 1994.

Yevell, H. Davis. Moving Mountains: A History of Presbyterian and Reformed Faith at Work in Appalachia. Amesville, Ohio: Coalition for Appalachian Ministry, 1985. 


\section{Appendix: Maps and Charts}

Figure 1. Membership of Select Protestant Churches in Keyser, West Virginia

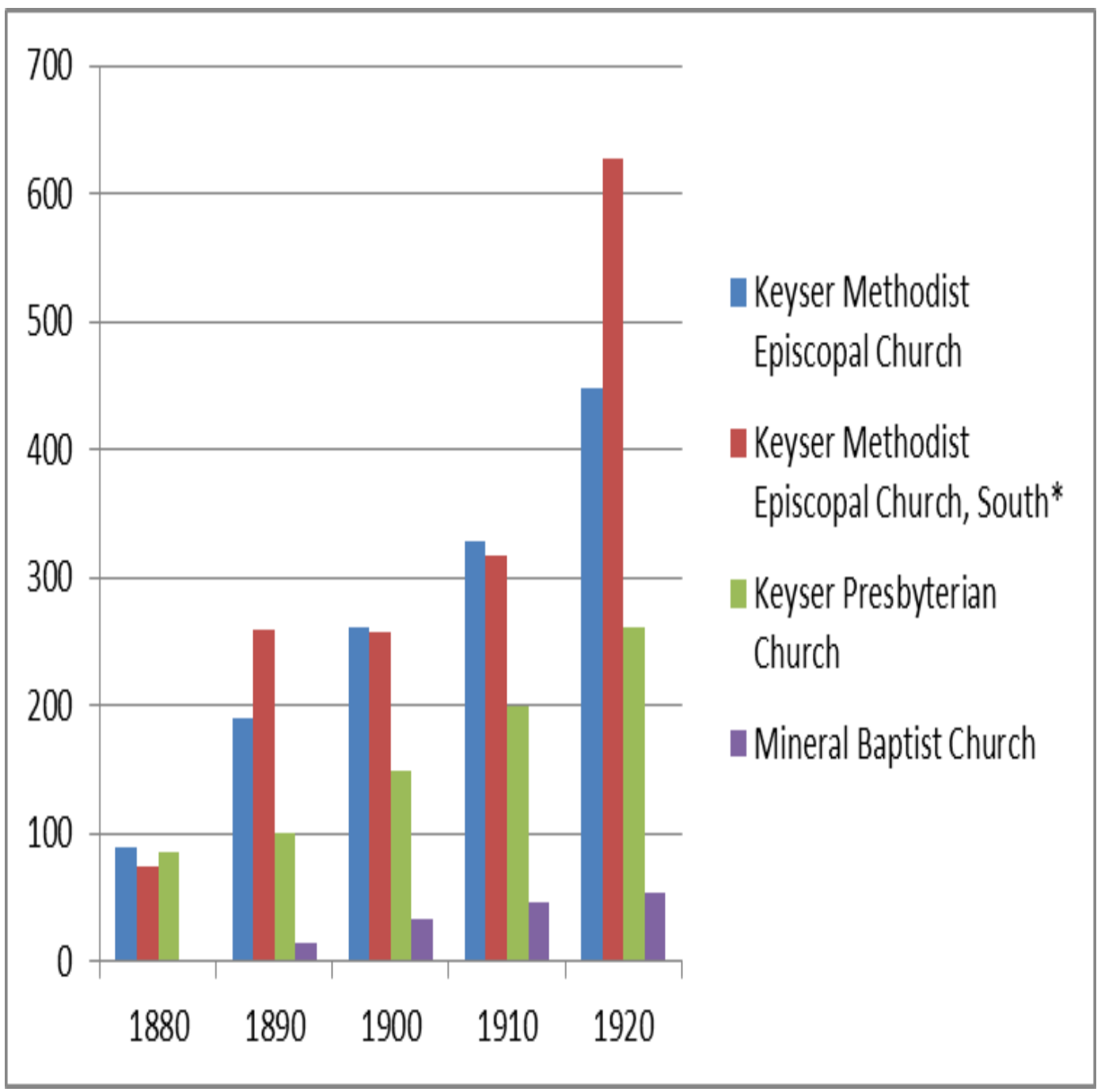

*The Keyser MECS was part of a circuit. Thus, its numbers here reflect multiple congregations. See Chapter 4. 
Figure 2. Membership of Select Protestant Churches in Parsons, West Virginia

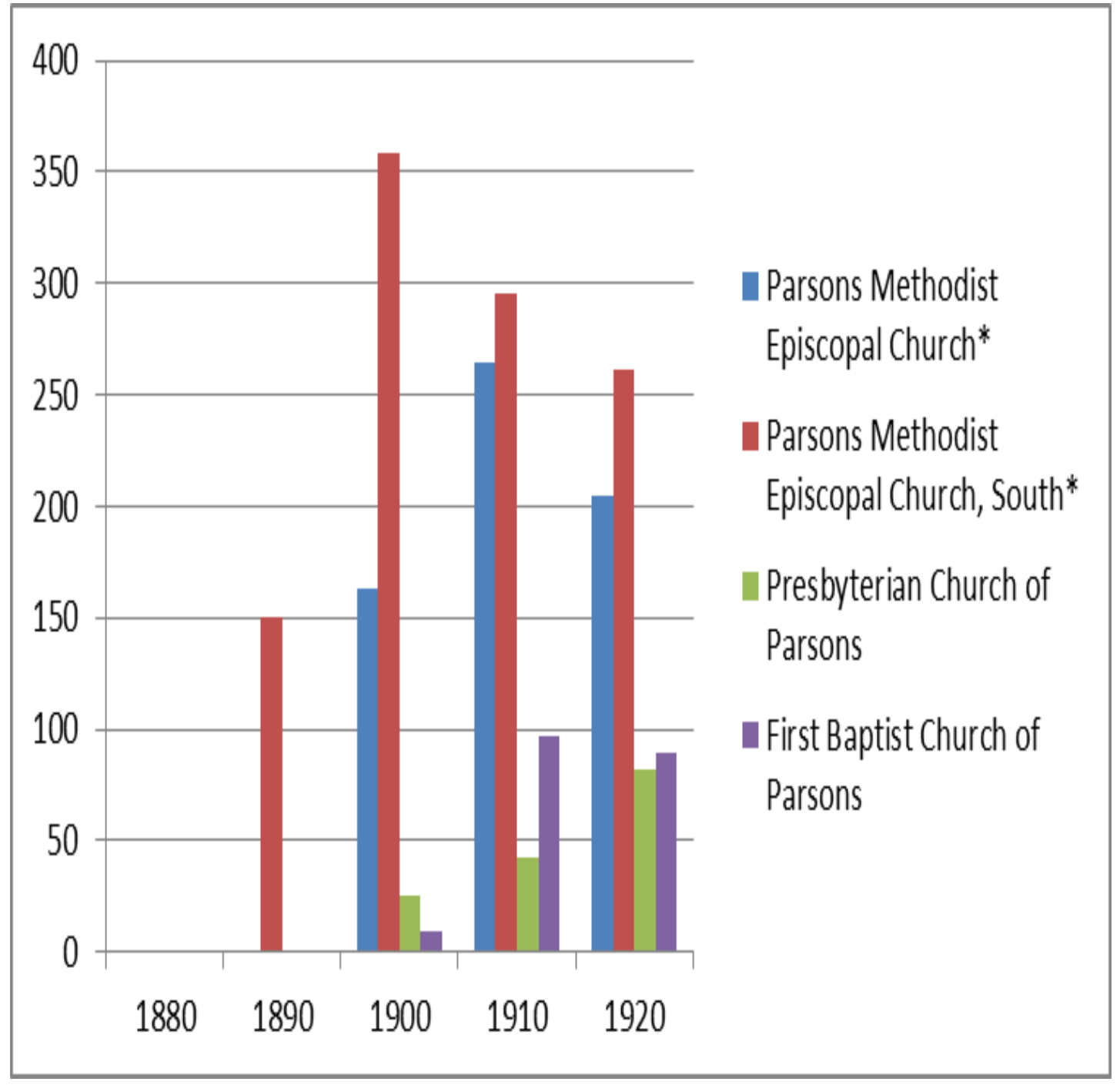

*Both the MEC and the MECS congregation in Parsons belonged to circuits. Thus, their numbers here reflect multiple congregations. See Chapter 4. 
Figure 3. Membership of Select Protestant Churches in Elkins, West Virginia

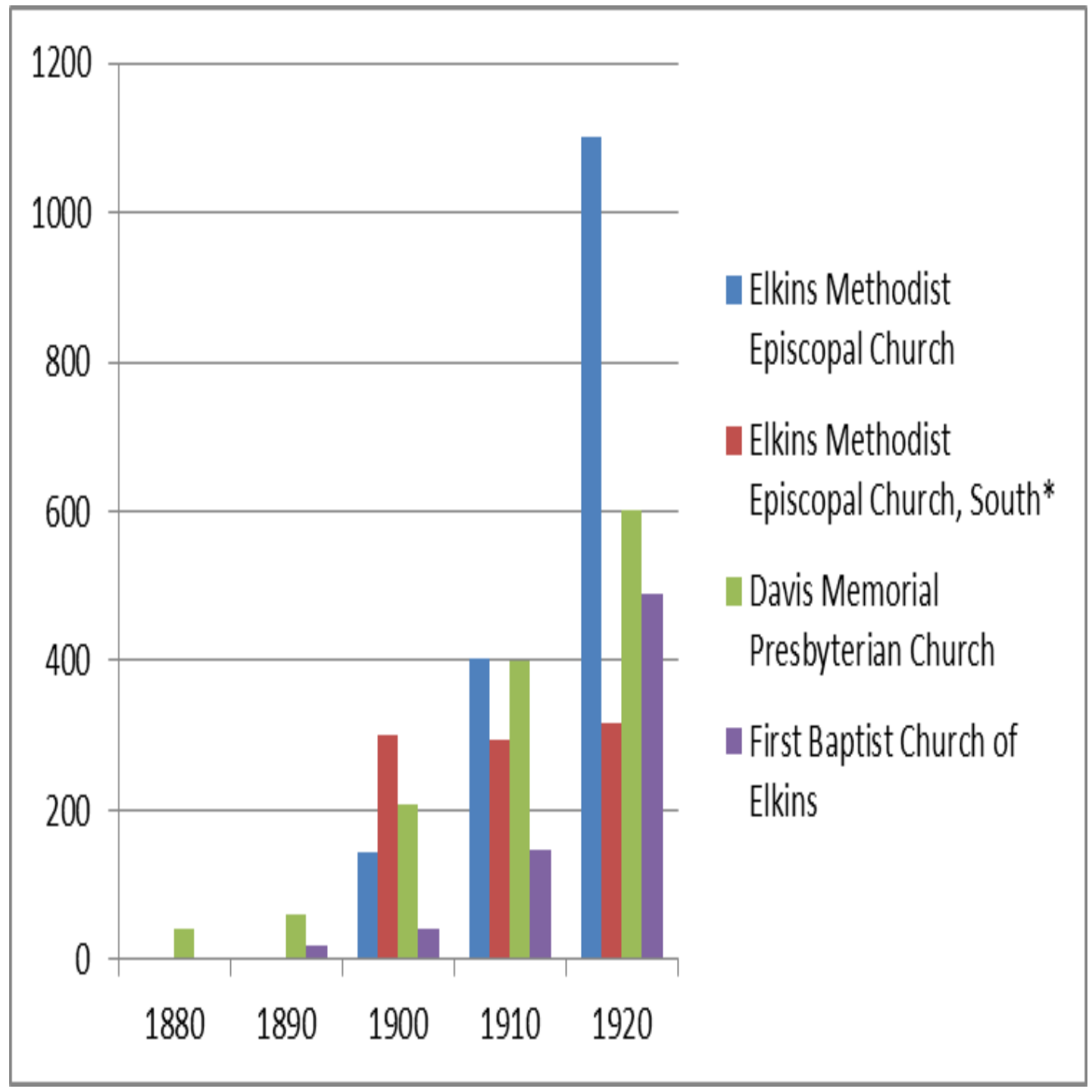

*The Elkins MECS congregation belonged to a circuit. Thus, its numbers here reflect multiple congregations. See Chapter 4. 
Figure 4. Membership of Select Protestant Churches in Marlinton, West Virginia

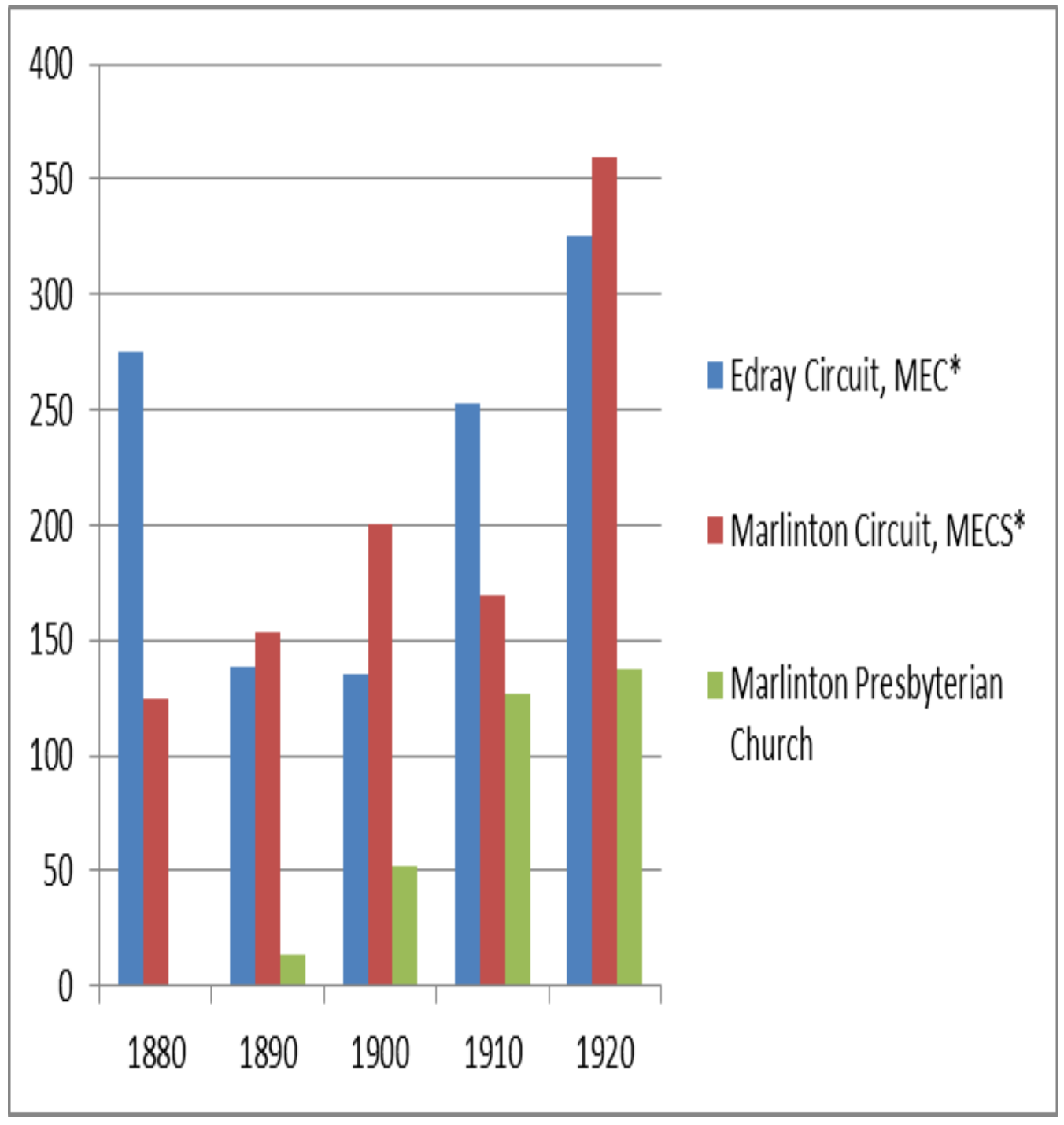

*The MEC and MECS congregations each belonged to circuits. Thus, their numbers here reflect multiple congregations. See Chapter 4. 
Figure 5. Map of West Virginia, including major railroads and select Protestant churches along the West Virginia Central and Pittsburg Railway and Coal and Iron Railway

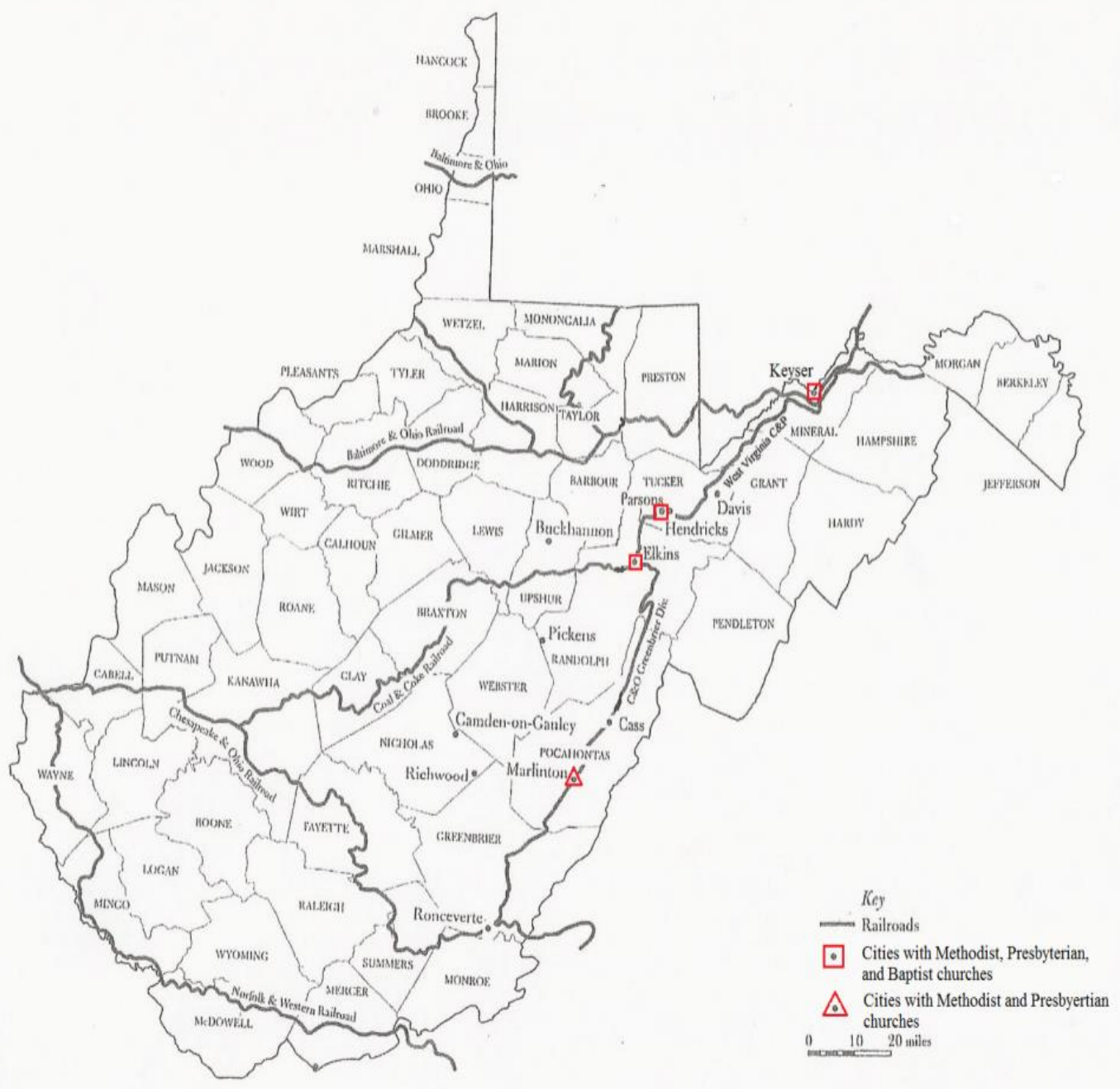

Taken from Ronald L. Lewis, Transforming the Appalachian Countryside: Railroads, Deforestation, and Social Change in West Virginia, 1880-1920 (Chapel Hill: The University of North Carolina Press, 1998), 48. Adapted by Josh and Katie Super. 